UNIVERSIDADE DE SÃO PAULO

FACULDADE DE FILOSOFIA, LETRAS E CIÊNCIAS HUMANAS

RENATA SCHLUMBERGER SCHEVISBISKI

A "obra" da ideologia e a ideologia na obra de Claude Lefort

(Versão corrigida)

São Paulo

2013 
RENATA S. SCHEVISBISKI

\title{
A "obra" da ideologia e a ideologia na obra de Claude Lefort
}

\author{
(Versão corrigida)
}

Tese apresentada ao Programa de Pósgraduação em Ciência Política, do Departamento de Ciência Política da Faculdade de Filosofia, Letras e Ciências Humanas da Universidade de São Paulo para obtenção do título de Doutor.

De acordo

Orientador: Prof. Dr. Cicero Romão Resende de Araújo

\section{São Paulo}


Autorizo a reprodução e divulgação total ou parcial deste trabalho, por qualquer meio convencional ou eletrônico, para fins de estudo e pesquisa, desde que citada a fonte.

Catalogação na Publicação Serviço de Biblioteca e Documentação

Faculdade de Filosofia, Letras e Ciências Humanas da Universidade de São Paulo

Schevisbiski, Renata Schlumberger

A "obra" da ideologia e a ideologia na obra de

orientador Cicero Romão Resende de Araújo. - São

Paulo, 2013.

$220 \mathrm{f}$.

Tese (Doutorado)- Faculdade de Filosofia, Letras

e Ciências Humanas da Universidade de São Paulo.

Departamento de Ciência Política. Área de

concentração: Ciência Política.

1. Ideologia. 2. Crítica. 3. Democracia. 4.

Político. 5. Lefort, Claude, 1924-2010.. I. Araújo,

Cicero Romão Resende de, orient. II. Título. 
SCHEVISBISKI, Renata Schlumberger. A "obra" da ideologia e a ideologia na obra

de Claude Lefort. Tese apresentada à Faculdade de Filosofia, Letras e Ciências Humanas da Universidade de São Paulo para obtenção do título de Doutor em Ciência Política.

Aprovado em:

\section{Banca Examinadora}

Prof. Dr. Cicero Romão Resende de Araújo (orientador)

Instituição: Universidade de São Paulo (USP)

Julgamento:

Assinatura:

Prof $^{\mathrm{a}}$. Dr ${ }^{\mathrm{a}}$. Eliana Maria de Melo Souza

Instituição: Universidade Estadual Paulista (UNESP - Araraquara)

Julgamento: Assinatura:

Prof. Dr. José Luciano Góis de Oliveira

Instituição: Universidade Federal de Pernambuco (UFPE)

Julgamento:

Assinatura:

Prof. Dr. Helton Machado Adverse

Instituição: Universidade Federal de Minas Gerais (UFMG)

Julgamento: Assinatura:

Prof. Dr. Sérgio Cardoso

Instituição: Universidade de São Paulo (USP)

Julgamento: Assinatura: 
Para Eder e Benjamin 


\section{Agradecimentos}

Ao meu orientador, Prof. Dr. Cicero Araújo, pela confiança e abertura oferecida para a realização deste trabalho, no momento em que aceitou orientá-lo, bem como pelas interrogações nascidas em nossas discussões, as quais permitiram construir as reflexões contidas nesta tese.

Ao Prof. Dr. Adrian Gurza Lavalle e Prof. Dr. Sérgio Cardoso, pelas questões e observações feitas no exame de qualificação, as quais contribuíram que estabelecesse novos caminhos de investigação.

Aos membros da banca de defesa, Prof ${ }^{a}$. Dra . Eliana Maria de Melo Souza, Prof. Dr. José Luciano Góis de Oliveira, Prof. Dr. Helton Machado Adverse e Prof. Dr. Sérgio Cardoso que aceitaram discutir este trabalho.

À CAPES pela bolsa concedida durante o período de realização desta tese.

Às secretárias do departamento de Ciência Política pelo auxílio e estima.

Aos meus colegas de trabalho, da Universidade Estadual de Londrina, pelo apreço e solidariedade.

Às minhas amigas do CRUSP, pelo companheirismo.

À minha família, pelos momentos de apoio e compreensão, servindo de incentivo fundamental para a finalização deste trabalho. Agradeço especialmente a Eder, por sua sensibilidade e carinho, estando sempre ao meu lado durante a criação da tese. A meu querido e amado Benjamin, por acontecer durante o doutorado, irradiando alegria e felicidade ao longo de todos esses dias. 


\section{Resumo}

SCHEVISBISKI, Renata S. A "obra" da ideologia e a ideologia na obra de Claude Lefort. 2013, 220 f. Tese (Doutorado) - Faculdade de Filosofia, Letras e Ciências Humanas, Universidade de São Paulo, São Paulo, 2013.

Esta tese realiza uma investigação da obra de Claude Lefort (1924-2010), com o objetivo de mostrar que a ideologia é central no entendimento, tanto do seu pensamento, como de sua teoria da democracia. Pressupõe-se que a ideologia não é simplesmente um objeto privilegiado de interpretação em seus escritos, pois o seu pensamento, seu trabalho sobre a obra de Maquiavel e de Marx, suas teorizações a respeito da democracia e do totalitarismo, fundamentam-se neste movimento de desvelar o significado das representações ideológicas, das certezas. Por meio da ideologia, podemos compreender o estatuto de seu discurso, o qual interroga e sabe ser habitado por ela, ao mesmo tempo que dela não se distancia e, estando nela enredado, busca a constância de uma interrogação acerca de seu conteúdo latente e das denegações por ela proferidas. Considera-se, por conseguinte, que, contrário a todo ponto de vista de certeza, o pensamento de Lefort aponta para uma reflexão sobre as ambiguidades da democracia, preocupando-se com aquilo que há de paradoxal nesta forma de sociedade e que a faz passar para o totalitarismo. Esta tese está estruturada em duas linhas de discussão: a primeira delas procura compreender a "obra" da ideologia na obra de Lefort, ou seja, parte da hipótese de que os seus movimentos de pensamento foram engendrando-se ao longo de sua trajetória com o objetivo de abrir novas vias para uma reflexão crítica, capaz de colocar a ideologia em questão. Nesse ponto, considera-se que a sua filosofia, enquanto pensamento do político, pode ser compreendida como aquela que se elaborou como crítica, deciframento e desvelamento da ideologia. A segunda discute a ideologia na obra de Lefort, preocupando-se em compreender a construção de sua reflexão e a significação atribuída pelo autor a ela, o que implica considerar os autores e acontecimentos que o influenciaram nesse processo, bem como a dinâmica de sua própria produção intelectual, isto é, os momentos em que o autor a tem como algo latente em seus artigos e naqueles em que ela se torna objeto explícito de discussão. Propõe-se que a ideologia está em toda a sua obra, até mesmo quando Lefort reflete sobre um tema central em seus estudos: a invenção democrática. Para isso, discutem-se os efeitos e consequências políticas da ideologia na democracia, pois embora ela seja instituída pela interrogação, movida pelo princípio de invenção e reinvenção permanentes, pela indeterminação, ela também se mostra petrificada, cristalizada e determinada pelo discurso ideológico.

Palavras-chave: ideologia, crítica, democracia, político, Lefort 


\begin{abstract}
SCHEVISBISKI, Renata S. The "work" of ideology and ideology in the work of Claude Lefort. 2013, 220 f. Tese (Doutorado) - Faculdade de Filosofia, Letras e Ciências Humanas, Universidade de São Paulo, São Paulo, 2013.
\end{abstract}

This thesis investigates the work of Claude Lefort (1924-2010) aiming to demonstrate that ideology is seminal to understand both his thought and his theory of democracy. We presume that ideology is not merely a privileged object of interpretation in his writings, since his thinking, his work on the writings of Machiavelli and Marx, and his theorizing on democracy and totalitarianism are based on the effort to reveal the meaning of ideological representations, of certainties. Ideology helps us to understand the statute of his discourse, which interrogates ideology and knows how to be inhabited by it and, at the same time, doesn't veer away from it. By being entangled in it, his discourse seeks the constancy of an interrogation on its latent content and the denials it pronounces. We defend therefore that, contrary to all points of views of certainty, Lefort's thought points to a reflection on the ambiguities of democracy; he is preoccupied with the paradoxical aspects of that form of society that make it shift toward totalitarianism. This thesis features two different lines of discussion. The first one seeks to understand the "work" of ideology in the work of Lefort, i.e., it is based on the assumption that his thought processes developed together with his pathway aiming to open new avenues for critical reflection that may question ideology. At this point, we assume that his philosophy - as the thinking of the political - can be understood as one which developed as criticism, the deciphering and unveiling of ideology. The second line discusses ideology in the work of Lefort and aims to understand the construction of his reflection and the meaning he gives it, which implies taking into account the authors and events that influenced that process, as well as the dynamics of his own intellectual production, i.e., the moments ideology appears as something latent in his articles and those where it becomes an explicit object of discussion. We suggest that ideology permeates his entire work, even when Lefort reflects on a central theme of his studies: the democratic invention. To demonstrate that, we discuss the political effects and consequences of ideology on democracy, because although the latter is established by interrogation, driven by the principle of permanent invention and reinvention, by indeterminacy, it is also petrified, crystallized and defined by the ideological discourse.

Keywords: Ideology. Critic. Democracy. Political. Lefort 


\section{LISTA DE SIGLAS*}

CA - Sur une colonne absente: écrits autour de Merleau-Ponty par Claude Lefort. Paris: Gallimard, 1978.

DEP - Desafios da escrita política. Tradução Eliana de Melo Souza. São Paulo: Discurso Editorial, 1999.

EL - Éléments d'une critique de la bureaucratie. 2ème ed. Paris: Gallimard, 1971.

FH - As formas da história: ensaios de antropologia política. São Paulo: Brasiliense, 1979.

HT - Un homme en trop. Réflexions sur 'L'Archipel du Goulag'. Paris: Seuil, 1976.

ID - A invenção democrática: os limites da dominação totalitária. Tradução Isabel Marva Loureiro. São Paulo: Brasiliense.

LC - La complication. Retour sur le communisme. Paris: Fayard, 1999.

LT - Le temps présent. Écrits 1945-2005. Paris: Belin, 2007.

LTO - Le travail de l'oeuvre Machiavel. 2ème ed. Paris: Gallimard, 1986.

PP - Pensando o político: ensaios sobre democracia, revolução e liberdade. Tradução Eliana de Melo Souza. Rio de Janeiro: Paz e Terra, 1991.

\footnotetext{
"Estas siglas abreviam os títulos dos livros de Claude Lefort e serão utilizadas em todas as nossas citações. Nosso objetivo é fazer com que o leitor localize com maior facilidade os artigos nas respectivas obras em que foram publicados.
} 


\section{Sumário}

CAPÍTULO 1 - Movimentos de pensamento.

Introdução

1. O círculo das crenças: da militância trotskista à saída do grupo Socialismo ou Barbárie ...... 27

1.1 Mitologia do partido: crítica à noção de partido e direção revolucionária....................... 28

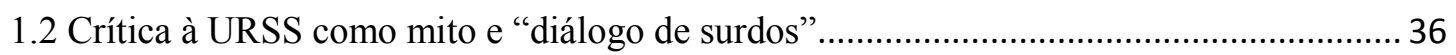

1.3 A degradação ideológica do marxismo ........................................................ 48

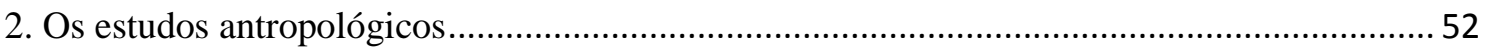

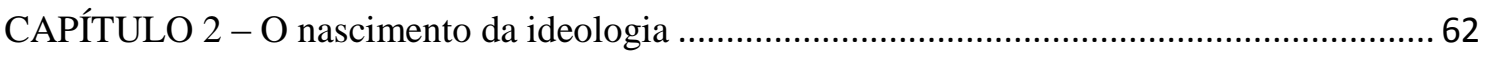

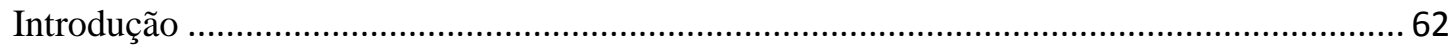

1. O debate da época: o problema de se partir do conceito ..............................................65

1.1 A recusa em partir do conceito de ideologia ........................................................ 66

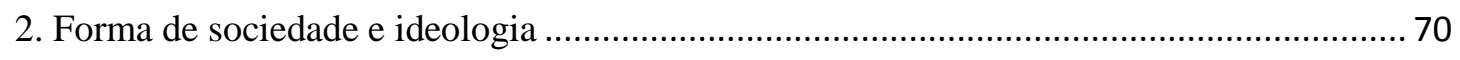

2.1 Forma de sociedade, história e ideologia ........................................................ 79

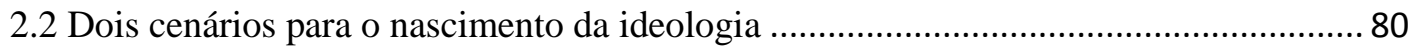

2.3 A gênese da ideologia no humanismo florentino em Maquiavel ............................. 84

2.4 A gênese da ideologia na sociedade burguesa em Marx ..................................... 96

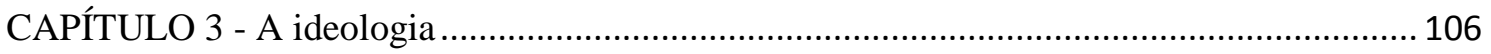

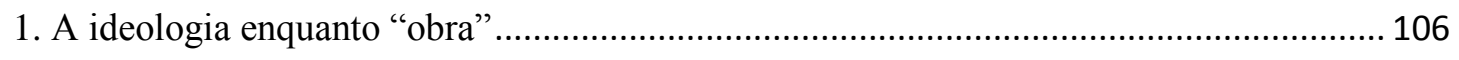

2. A ideologia "dita" burguesa ............................................................................... 114

2.1 A contradição da ideologia burguesa ....................................................... 121

3. A ideologia totalitária .............................................................................. 123

3.1 A contradição da ideologia totalitária ........................................................ 134

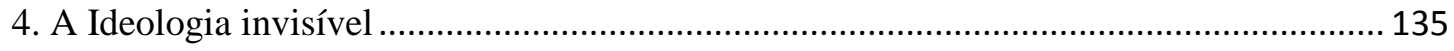

4.1 A contradição da ideologia invisível ....................................................... 145

CAPÍTULO 4 - A “obra” da ideologia na "invenção democrática” ..................................... 148 
Introdução

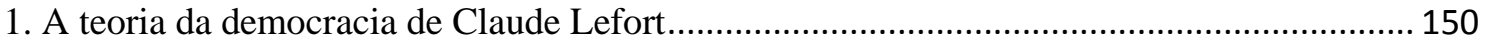

1.1. Aportes críticos para a nova tarefa intelectual: (re)pensar a democracia ........................ 150

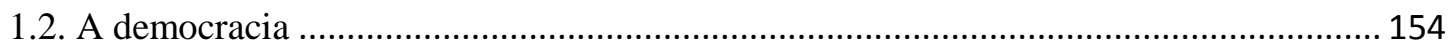

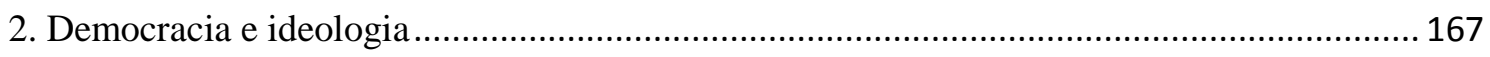

2.1. A (re)invenção democrática e o determinismo ideológico............................................ 172

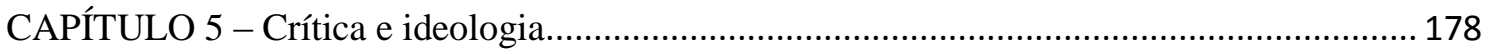

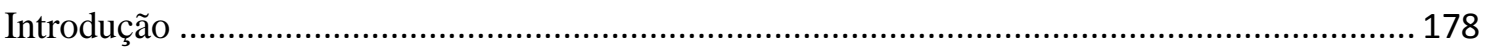

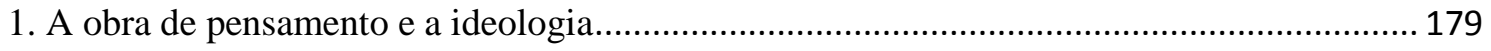

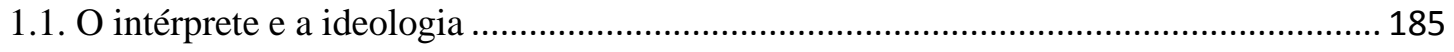

1.2. A interrogação da ideologia ................................................................................... 195

1.3. O pensamento do político como pensamento crítico da ideologia .................................. 199

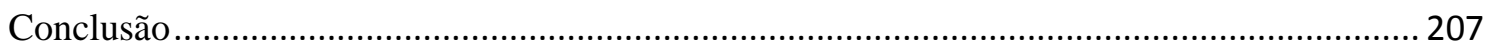

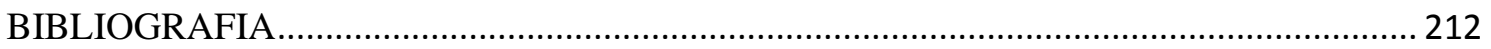




\section{Introdução}

A obra de Claude Lefort é composta por inúmeros artigos, escritos ao longo de sessenta anos. Com exceção dos livros Mai 68: La Brèche, escrito em colaboração com Edgard Morin e Cornelius Castoriadis e publicado pela primeira vez em 1968 (MORIN, LEFORT e CASTORIADIS, 2008), Le travail de l'oeuvre Machiavel (1986c), Un homme en Trop. Réflexions sur "L'Archipel du Gulag” (1976b) e La complication. Retour sur le communisme (1999b), toda a sua reflexão consiste em textos publicados em diversas revistas como Les temps modernes, Socialisme ou Barbarie, Cahiers Internationaux de sociologie, Textures, Esprit, Libre, Libération, Passé-Présent, entre outras. Muitos destes artigos foram reunidos posteriormente em livros ${ }^{1}$, cujos prefácios traduzem a tentativa de organizar um trabalho que sempre se distanciou de um projeto didático sistemático, do formato de uma tese acadêmica, tão característico da maior parte dos trabalhos filosóficos e científicos.

Reorganizados e reapresentados como livros ao público, eles guardam, de certa maneira, uma íntima relação com a estrutura de certos livros de literatura, como os de contos que, uma vez reunidos, cada um abre a seu leitor o acesso a um mundo de questões e de reflexões que são tecidas pela narrativa do autor em suas múltiplas entonações, pausas, naquilo que coloca em relevo, ou, ainda, nos conteúdos latentes, nas personagens que somente são na trama que as articula ${ }^{2}$. Nos livros de Lefort, cada artigo abre uma via interrogativa, revela um percurso de seu pensar, a relação que manteve com certos autores, fatos e circunstâncias políticas, com os acontecimentos de sua época, articulando-os como fios de uma argumentação mais extensa acerca do

\footnotetext{
${ }^{1}$ Fazemos referência às obras Les formes de l'histoire. Essais d'anthropologie politique (1978a), Sur une colonne absente. Écrits autour de Merleau-Ponty (1978f), Éléments d'une critique de la bureaucratie (1979c), L'invention démocratique. Les limites de la domination totalitaire (1981a), Essais sur le politique. XIX ${ }^{\mathrm{e}}$-XXe siècles (1986a), Écrire à l'épreuve du politique (1992a) e Le temps présent. Écrits 1945-2005 (2007).

${ }^{2}$ Tal analogia com a literatura, por sua vez, não é fortuita, pois o filósofo Lefort se vê escritor literário, nomeia-se "escritor-filósofo" e seu desejo mais antigo por esta vocação não lhe escapa da memória, tendo nascido muito cedo, ainda em sua adolescência. Seu trabalho interrogativo lhe é concebido como trabalho de expressão, de produção de uma obra na qual o pensamento se busca, por meio da escrita, desvelandose e inventando-se simultaneamente e de maneira indissociável da interpretação. Um trabalho que não se distanciou da literatura e da poesia como podemos perceber nos seus escritos sobre Soljenitsin, em especial no livro Un homme en trop. Réflexions sur "L'Archipel du Goulag”(1976b) e Orwell, no artigo "O corpo interposto: 1984 de George Orwell” (1984a), presente no livro Desafios da escrita política (1999a). Na sua perspectiva, cada filósofo deve acolher, ao invés de denegar, sua vocação de escritor (LEFORT, 1999a, p. 347).
} 
significado da sociedade moderna, como sociedade histórica, da democracia e do totalitarismo.

Há um propósito salutar neste discurso filosófico que se dá sob a forma de artigos, pois para o autor, trata-se de manter aberta a interrogação, posto que é trabalho que se faz e refaz constantemente em sua interpelação do presente, em contato com certos temas, com os acontecimentos, com as circunstâncias de cada época. No plano deste movimento, abre-se para o leitor a constância de reinícios, pois cada artigo lido de modo algum encerra em si mesmo o trabalho de entendimento pela colocação de um ponto final à questão que o fez falar. Em certos momentos da leitura, o leitor é tomado pela sensação de que a obra dele se furta, pois o autor não lhe dá todas as respostas que almejaria encontrar, comandando, então, um movimento de leitura e releitura, capaz de multiplicar suas questões.

Exploração contínua, a obra de Lefort pode ser lida de várias maneiras. A mais aberta de todas toma como ponto de partida qualquer artigo, qualquer capítulo, pois cabe ao leitor ligar estes fios e refazer o tecido de seu discurso, bastando-lhe estar munido de questões para percorrê-la. Outra maneira possível de compreender a obra de Lefort é partir de suas publicações em revistas, retomando-a no plano de dossiês temáticos, na sequência de artigos entre os quais os seus se localizam, na relação que mantêm com os autores e suas ideias a dividir o mesmo volume, o mesmo número, ou, ainda, com certo grupo editorial. Outro caminho, por sua vez, apreende o significado da republicação de seus artigos reorganizados em livros. O esforço, presente em cada um de seus prefácios em justificar a reapresentação de certos textos já conhecidos do público, articulando-os ao momento político em questão, confrontando suas análises com a dinâmica do tempo, de cada aqui e agora, revela um autor dedicado a combinar a reflexão política com o deciframento dos fatos políticos. Assim, cada livro contempla uma sequência única de artigos selecionados e reorganizados pelo autor. Seus prefácios e posfácios, em nossa perspectiva, constituem amarrações de seu próprio discurso, visando articular e rearticular suas interrogações aos acontecimentos, ao cenário político e, particularmente, aos discursos e às representações da época.

Desta forma, seus livros não são meras coletâneas de artigos, pois o autor os rearticula frente ao cenário político mais amplo. Tal é o caso de Éléments d'une critique de la bureaucratie, publicado em 1971 e reapresentado ao público em 1979, em que 
Lefort mobiliza e retoma suas interrogações dos anos 1950 e 1960, articulando-as em seu pósfacio não apenas para apontar seu próprio itinerário de reflexão, mas para elucidá-las ao leitor que acabara de vivenciar Maio de 1968 na França, um acontecimento inesperado para uma democracia e que, para Lefort, a teoria de Marx e, por conseguinte, a esquerda marxista não poderia explicar. Da mesma forma, ele procura retomar um conjunto de reflexões ao leitor que porventura desconheça os debates dos anos 1950 sobre o caráter totalitário da URSS, afirmando que uma parte do quadro histórico mantém-se, de forma que as questões então colocadas, as críticas desferidas por Lefort àquele regime ainda adquirem ressonância frente ao discurso que tende a considerá-lo como algo acidental. Na reedição desta mesma obra, publicada em 1979, vários artigos são retirados $^{3}$, não constituindo simplesmente um trabalho de revisão editorial, pois Lefort rearticula novamente suas antigas questões frente a um novo cenário político, no qual a esquerda já reconhece, mas denega $a^{4}$ os horrores cometidos pelo regime totalitário na URSS.

O mesmo ocorre com a obra L'invention démocratique. Les limites de la domination totatalitaire, publicada em 1981 na França. Seu prefácio visa recolocar o problema do totalitarismo e da democracia na "ordem do dia", rearticulando reflexões antigas, textos de conjuntura, muitos dos quais escritos às pressas frente às dissimulações, à tentativa inerente aos dirigentes do Partido Socialista e do Partido Comunista Francês - partidos que criaram a chamada "União da Esquerda" - em soterrar a natureza do Estado totalitário na campanha presidencial de $1981^{5}$.

\footnotetext{
${ }^{3}$ Na publicação da segunda edição do livro Éléments d'une critique de la bureaucratie em 1979, foram mantidos os artigos "Kravchenko et le probléme de l'URSS", "La contradiction de Trotsky", "Le totalitarisme sans Stalin", "La méthode des intellectuels progressistes", "Organisation et parti", "Qu'estce que la bureacratie?", "La dégradation idéologique du marxisme", "Pour une sociologie de la démocratie", "Résurrection de Trotsky?", e retirados os artigos: "Le trotskisme au sevice du titisme", "Témoignage révolutionnaire sur l'URSS", "Pascal, histoire et sociologie dans l'oeuvre de Fernand Braudel", "Le marxisme et Sartre", "De la réponse à la question", "Juin 1936", "Retour de Pologne". Nessa nova edição, foram inseridos os artigos "Le prolétariat et sa direction", "Le témoignage d'Anton Ciliga", "Le nouveau et l'attrait de la répétition".

${ }^{4}$ A palavra "denegação" (dénégation), oriunda do vocabulário psicanalítico, é utilizada por Lefort nos anos 1970, conforme explicitaremos, visto que ela revela a atitude da esquerda comunista francesa, a qual reconhece o fato totalitário, mas mostra-se incapaz de apreendê-lo em toda a sua significação, referindose a "totalitarismo" com a mesma significação de poder autoritário e arbitrário, neutralizando, portanto, todo o sentido crítico daquele vocábulo.

${ }^{5}$ Destacamos que esta obra foi traduzida e publicada no Brasil em 1983, o que nos faz levantar a hipótese de que ela pode ter se inserido no debate mais amplo sobre o significado da prática democrática em um contexto de transição política. A leitura que dela foi feita, no entanto, bem como suas repercussões no plano de nossas ideias e práticas políticas é uma pesquisa a ser realizada. É possível encontrar uma referência à importância daquele livro em nosso processo de redemocratização em Oliveira (2010).
} 
Estas duas obras, portanto, ilustram a relevância de abordarmos o pensamento de Lefort por meio de seus livros. Neste percurso interpretativo, os prefácios tornam-se escritos fundamentais, pois não constituem textos preparados para a publicação em revistas, como a maior parte de seus estudos, nem expostos em Conferências temáticas para um público ouvinte, sendo também distintos das entrevistas por ele concedidas. Trata-se de textos voltados para o leitor de uma obra, ou seja, para o leitor que travará contato com um conjunto de interrogações formuladas em diferentes artigos, muitos dos quais escritos em épocas diferentes e que, à primeira vista, poderia pressupor nada encontrar de novo. Os prefácios, então, querem manter essa proximidade com o leitor, seja ele iniciante ou já tendo experimentado certos debates e querelas intelectuais. Eles exprimem a natureza de sua trajetória, marcada por "itinerários não combinados de antemão" (FH, [1978c] 1979b, p. 19) ${ }^{6}$ e que são rearticulados pelo autor de um modo diferente daquele que realiza em entrevistas, por exemplo, em que sua fala remete-se às questões postas por seu entrevistador. Os prefácios podem ser lidos como textos que se assemelham a panoramas, ou seja, que esboçam ao leitor uma perspectiva interna da obra de Lefort que, por sua vez, lança e explora suas questões, as articula entre períodos díspares de sua produção e as rearticula a cenários históricos. É por isso que, ao longo de nossas discussões, seguiremos estes panoramas.

Encontramos nos prefácios uma espécie de "amarração" feita pelo autor, no sentido de procurar inserir seu leitor em um conjunto de reflexões filosóficas que jamais se distanciam da política. Nesse sentido, a todo momento, Lefort procura articular sua interrogação junto ao cenário político, marcado por acontecimentos e discursos interpretativos e ideológicos, revelando um traço fundamental de seu pensamento: o fato de que suas reflexões sempre estão voltadas para fatos sociais e políticos. Entre suas preocupações fundamentais, encontramos o exame de certos acontecimentos, seja no quadro francês, como o advento do gaullismo, Maio de 1968, a criação da União da Esquerda nos anos 1970, seja no quadro europeu, as mudanças no Leste, a Revolução Húngara, a desestalinização comandada por Kruschev. Ao mesmo tempo, Lefort produziu diversos trabalhos em torno da obra de pensadores como Maquiavel, Marx, Tocqueville, La Boétie, Michelet, Quinet, Arendt, Leo Strauss, entre outros, de tal

\footnotetext{
${ }^{6}$ Optamos por fazer referência às obras de Lefort através das siglas que as identificam, conforme listado na página oito (p.8), assim como aos artigos. Assim procedemos com o objetivo de evidenciar o movimento interrogativo do pensamento do autor, o qual cria aberturas, em cada artigo, e busca reinserilos em nova composição temática através de seus livros. Dessa maneira, utilizamos as siglas e duas datas: a primeira cita o artigo entre colchetes e, a segunda, a data de sua republicação em livro.
} 
forma que sua filosofia não dissocia o trabalho que seria voltado para o universo das obras de uma reflexão a respeito da "realidade sócio-histórica" (DEP, [1985] 1999a, p. $343)$.

Em Lefort, duas exigências se coadunam: a exigência filosófica ${ }^{7}$ e a exigência política. A relação da filosofia com a política foi aos poucos se delineando em sua trajetória, constituindo-se como um problema a ser cada vez mais confrontado, uma vez que Lefort recusou-se a conceber um lugar definido para a filosofia e, ao mesmo tempo, de obscurecê-la em favor da política (cf. DEP, [1985] 1999a, p. 342). A filosofia e a política percorrem sua obra, associando o trabalho de interpretação do pensamento de autores do passado com o exame dos acontecimentos contemporâneos. A exigência política, portanto, significou no seu pensamento, a possibilidade do não fechamento da filosofia em si mesma (ibid., p. 344). Até mesmo a escolha de certas obras e autores como Maquiavel, Tocqueville, Michelet, Quinet, não deixa dúvidas quanto a esse traço, uma vez que são autores cujo pensamento se mantém atento às condições do regime político em seu próprio tempo.

Eu deveria então reconhecer que meus próprios heróis eram pensadores que haviam depositado toda a energia na tentativa de analisar e modificar as condições do regime político em seu tempo: Maquiavel, ao qual consagrei um trabalho, e não ouso dizer o tempo que me ocupou, La Boétie, Espinosa, e depois, em poucos anos, alguns escritores franceses que combateram arduamente pela causa da democracia ou do socialismo, entre os quais estão, em primeiro lugar, Michelet e Quinet. Eu estava omitindo Marx...Estranho esquecimento, já que nenhuma obra, como a de Marx, abriu caminho para minhas próprias questões, a não ser a obra de Maquiavel, ou a obra de um contemporâneo de quem fui aluno, também habitado pela política: Merleau-Ponty. (DEP, [1985] 1999a, p. 342)

Plenamente imbricadas na obra de Lefort, as dimensões filosófica e política conjugam-se a fim de pensar os acontecimentos que marcaram o estabelecimento da sociedade moderna, em especial a democracia e o totalitarismo. Em toda a sua extensão, ela traz a marca das questões de seu próprio tempo, dos acontecimentos, dos debates, de tal forma que, em seus diversos ensaios, ela interpela o presente. Nessa perspectiva,

\footnotetext{
${ }^{7}$ Por "exigência filosófica", Lefort compreende que ela "nasceria, renasceria de toda parte, e seria regida, para o escritor-filósofo, pelo apelo da obra, na qual a questão permanece em busca de si mesma, reitera-se valendo-se de todos os lugares a que seu desejo singular o conduziu." (DEP, [1985] 1999a, p. 347-348). Tal exigência, portanto, recolhe-se no plano da obra filosófica, pois nela o pensamento se busca, se expressa e se inventa em sua tarefa de expressão pela linguagem. Para compreender melhor essa perspectiva, devemos realizar um entendimento do que constitui para Lefort o trabalho de interpretação de uma "obra de pensamento", através de seu estudo sobre Maquiavel (LTO, 1986c), seguindo as influências da filosofia de Merleau-Ponty nesta perspectiva.
} 
torna-se fundamental apreender esta via política da obra para que seja possível um entendimento sobre os movimentos de pensamento seguidos pelo autor em cada um de seus $\operatorname{artigos}^{8}$. Assim, consideramos que, se as vias "reais" da política, entendidas como acontecimentos, adentram o pensamento de Claude Lefort, elas não constituem apenas um pano de fundo para o desenrolar de suas reflexões, elas são uma exigência a convocar o exercício de seu pensamento e de sua palavra.

Chegamos, assim, ao problema a ser discutido nesta tese. Uma vez pressuposto que a obra de Lefort revela-se no enlace com os debates políticos de seu próprio tempo, com os acontecimentos, consideramos que ela visa colocar em questão determinadas representações sobre a democracia e sobre o totalitarismo presentes nos discursos de sua época. Lefort procura dar passagem a uma reflexão que quer se libertar dos quadros da ideologia contemporânea e busca compreender os seus sinais responsáveis por impedir um questionamento necessário para Lefort: "face à experiência do totalitarismo, repensar a natureza da democracia." (LT, [1978e] 2007, p. 366) ${ }^{9}$. Face à denegação do totalitarismo, ao ódio à democracia burguesa preconizado por intelectuais da esquerda marxista, desde os anos 1950, Lefort ressalta que se encontra escondida a verdade da democracia, o sentido da revolução democrática, afirmando que "o que se esconde da imaginação é a própria democracia" (ID, [1980b] 1983a, p. 68). Dessa forma, sob tais circunstâncias e frente a este discurso denegador é que estabelece seu modo de repensar o político e a democracia.

Partimos da hipótese de que a ideologia é central no entendimento, tanto do pensamento de Lefort, como de sua teoria da democracia. A ideologia nos dá a dimensão do estatuto de seu discurso, um discurso que a interpela e que sabe ser habitado por ela, que dela não se distancia e que, estando nela enredado, busca a constância de uma interrogação acerca de seu conteúdo latente, das denegações por ela

\footnotetext{
${ }^{8}$ Dessa forma, preconizando o não fechamento da filosofia em si mesma, Lefort está voltado para um projeto de reavivamento da filosofia política. Na sua visão, ela não é uma disciplina que possa ser considerada no mesmo quadro da biologia molecular, por exemplo. Ela não pode ser considerada como "um espaço fechado que se definiria pelo diálogo dos filósofos entre si" (LT, [1988] 2007, p. 600). Ao mesmo tempo, não deve abandonar toda a tradição filosófica, devendo, por uma parte, abarcar toda essa pesquisa e reflexão anteriores e, por outra parte, de modo indissociável, manter uma interrogação sobre o tempo no qual se vive (ibid., p. 601).

${ }^{9}$ As versões em português das obras de Lefort não traduzidas, no Brasil, são de nossa inteira responsabilidade. Fizemos a opção por utilizar também a tradução brasileira, pois favorece a interlocução com outros pesquisadores e estudantes que estejam iniciando seus estudos sobre a obra de Lefort, tendo em vista a possível dificuldade no acesso às obras em francês, bem como a pouca disseminação de trabalhos sobre o autor em nossa comunidade acadêmica. Nos momentos em que se julgar necessário serão cotejadas as traduções vigentes e apresentadas a nossa versão.
} 
proferidas. Sua palavra, portanto, não se separa de um discurso coletivo pronunciado pela esquerda que visa atacar a democracia, concebendo-a como democracia burguesa, a denegar o totalitarismo, evitando vê-lo em sua feição opressora, ou, ainda, a conceber novas e belas representações sobre a boa sociedade, onde vigoraria a ausência do conflito político. Pôr em questão estas representações nos parece estar no cerne de seu pensamento e de sua teoria da democracia, uma vez que seu discurso tem o peso de um ataque, quer produzir um ferimento na ideologia que influencia grande parte da intelligentsia francesa. Desta forma, colocamos em relevo o entrelaçamento de discursos, pois o pensamento de Lefort se dá nesta implicação com discursos outros, com ideologias que visam estabelecer certezas sobre o Ser do social, que visam recobrir as questões do tempo, ou seja, as questões formuladas pelos homens em cada aqui e agora e que têm o efeito de criar possíveis.

Lefort, ciente do peso dos dogmas, das certezas fixadas com relação a uma obra de pensamento, seja a de Marx ou de Maquiavel, com relação a um acontecimento, como o totalitarismo e a democracia, compreende que a ideologia impede o movimento virtuoso da interrogação, da incerteza, responsáveis por desencadear um movimento de contradição com as práticas e representações instituídas. A ideologia cumpre um papel na sociedade moderna, nesta sociedade histórica, marcada por tensões, ambiguidades e paradoxos, particularmente no seio da sociedade democrática, para agenciá-la contra a história. Nela, a ideologia cria as condições para o travamento de sua natureza revolucionária, do incessante trabalho de reinvenção democrática promovido por movimentos políticos, pelas contestações em torno dos direitos humanos, enfim, pela dinâmica do conflito. A ideologia pode impedir que os homens cedam à atração do novo, dos acontecimentos que afetam profundamente a sociedade política, suas experiências e, inclusive, a sua emergência no plano do debate. Ela trabalha em favor de um desejo de conservação.

A possibilidade da crítica à ideologia, segundo Lefort, depende do trabalho constante do pensamento que não acontece fora da ideologia, sabe ser habitado por ela, que a encontra no fundo de si mesmo e que somente o trabalho interminável da interrogação que ocorre na interpretação, dela pode se libertar ${ }^{10}$. Sua filosofia sugere,

\footnotetext{
${ }^{10}$ Nesta tese, adquire importância o modo como Lefort concebe o trabalho de interpretação de uma obra de pensamento, pois o discurso de um autor, o discurso de seu intérprete que visa dizer a verdade da obra,
} 
por conseguinte, que o homem democrático não deve negar as certezas comuns que partilha, mas, ao manter a interrogação aberta, uma ética da dúvida, encontra-se capaz de perceber que a certeza é indissociável da incerteza, devendo reunir-se às ambiguidades que a ideologia cobre enquanto discurso sobre o social. $\mathrm{O}$ aprofundamento democrático depende, portanto, do trabalho da interrogação, pois a democracia não está ao abrigo das ideologias e suas instituições não são garantias de que sua passagem para o totalitarismo não poderá ocorrer.

Pressupomos que a ideologia em Lefort não é simplesmente um objeto privilegiado de interpretação. Ela parece ser o elemento a partir do qual a interpretação, propriamente dita, se extrairia e nunca acabaria de extrair-se. Todo o seu pensamento, seu trabalho sobre a obra de Maquiavel e de Marx, suas teorizações a respeito da democracia e do totalitarismo, poderiam fundamentar-se neste movimento de desvelar o significado das representações ideológicas, das certezas. Procuraremos mostrar que essa renúncia em visar a obra de um autor e o social como objetos, contendo um sentido inteiramente positivo ou uma determinação prometida ao conhecimento, faz com que Lefort busque apreender "na história, na vida social ou nas obras de outrem, as discordâncias, as contradições, as fraturas que são sinais da indeterminação do sentido" (FH, [1978c] 1979b, p. 15-16). Por conseguinte, consideramos que, contrário a todo ponto de vista de certeza, o pensamento de Lefort aponta para uma reflexão sobre as ambiguidades da democracia, preocupando-se com aquilo que há de paradoxal nesta forma de sociedade e que a faz passar para o totalitarismo.

Tudo indica que o discurso teórico de Lefort espelha este movimento. Assim, o leitor que espera encontrar em sua obra uma reflexão sobre a democracia e sua relação com o totalitarismo, nos moldes de uma sequência ordenada de argumentos, uma linha de raciocínio em forma de tese, perceberá que o autor contrapõe-se a esta forma acabada e a toda tentativa de fechamento de suas próprias ideias. Encontramo-nos implicados neste movimento de modo que toda tentativa de sistematização, de ordenamento, toda procura que se valha do desejo de encontrar teses prontas e sistematizadas deve assumir-se incapaz de compreender a obra de Lefort. Ela somente se revela ao leitor que não busque ter sobre ela um domínio, que consinta em perder seus pontos de apoio, acolhendo pela escrita o movimento de pensamento do autor: aquilo que o move e o 
demove para fora das posições assumidas (cf. DEP, [1985] 1999a, p. 343), o qual, por sua vez, é habitado pela interrogação, pela contradição (EL, [1979f] 1979c, p. 27). Assim, ao invés de nos preocuparmos em estabelecer uma sequência ordenada de suas ideias, dos conceitos que abarca, procuramos restituir as aventuras (DEP, [1985] 1999a, p. 343) vividas pelo pensamento de Lefort, buscando aquilo que o move e o demove constantemente em torno de suas próprias posições políticas e intelectuais.

Lefort fez, a nosso ver, a escolha por uma certa escrita, por um modo de escrever que é marcada pela interrogação, justamente com a finalidade de não se fechar como tese; e também que busca desmanchar as armadilhas da crença, do mito, que busca subtrair-se à captura da ideologia. Seguir este movimento pode nos levar a compreender seu modo de proceder que estabelece distinções entre democracia e totalitarismo para, em seguida, as embaralhar e não as apagar. $\mathrm{Na}$ mesma trilha de Maquiavel nos Discorsi, Lefort

Faz reaparecer em uma perspectiva o que apagara em outra e mantém os contrários. Uma vez que percebeu que nenhuma fronteira separa o bem do mal, vai até o ponto de reconhecer que o melhor engendra o pior não porque boas intenções engendrem maus efeitos, mas porque, mais profundamente, aquilo que atinge na realidade a forma mais acabada é o agente da decomposição mais extensa. (FH, [1960b] 1979b, p. 204)

Dessa maneira, as relações de proximidade e distanciamento entre democracia e totalitarismo presentes na obra de Lefort parecem ser constantes. Nesse sentido, lhe importa refletir sobre as virtudes, os paradoxos, as ambiguidades, ver para onde ela se presta à formação de ideologias e de movimentos totalitários, os sinais de sua desvitalização, decifrando as marcas de sua emancipação, de seu aprofundamento e as marcas de novas formas de servidão e, da mesma forma, em ressaltar que as críticas dirigidas a ela não devem nos fazer esquecer suas virtudes.

Este movimento de seu pensamento apenas revela-se, a partir do momento em que se compreende o significado da ideologia em sua obra. É a partir dela e contra ela este discurso de sobrevoo, ponto de vista de certeza - que Lefort tece sua narrativa e elabora sua teoria da democracia. De certa forma, Lefort parece se encontrar na mesma condição de Maquiavel, enquanto este tratava de pôr em questão a representação de Roma, tendo o alcance de um ataque contra a ideologia que influenciava a juventude de Florença; Lefort tratou de questionar a representação da democracia e do totalitarismo, 
atacando a ideologia de sua época, o que significa pensar o discurso de Lefort como aquele que trabalha e é trabalhado pela ideologia.

Visamos discutir um aspecto presente no pensamento de Lefort: o problema das representações ideológicas na sociedade moderna, em especial, na democracia. $\mathrm{O}$ tema da ideologia permite-nos uma compreensão da obra de Lefort, no plano do desenvolvimento de suas teorizações em torno do político, na medida em que esclarece os contornos de sua perspectiva acerca do problema das denegações políticas; e em torno da democracia e do totalitarismo, uma vez que abre a discussão sobre os paradoxos e ambiguidades presentes no regime democrático que a fazem passar para o regime totalitário, ao mesmo tempo, indica-nos sob quais condições é possível a desvitalização e o aprofundamento democrático.

Esta tese está estruturada em duas linhas de discussão. A primeira delas procura compreender a "obra" da ideologia na obra de Lefort, ou seja, parte da hipótese de que os seus movimentos de pensamento foram engendrando-se ao longo de sua trajetória com o objetivo de abrir novas vias para uma reflexão crítica, capaz de colocar a ideologia em questão. Nesse ponto, consideramos que a sua filosofia como pensamento do político pode ser compreendida como aquela que se elaborou como crítica, deciframento e desvelamento da ideologia. A segunda discute a ideologia na obra de Lefort, preocupando-se em compreender a construção de sua reflexão e a significação atribuída pelo autor a ela, o que implica considerar os autores e acontecimentos que o influenciaram nesse processo, bem como a dinâmica de sua própria produção intelectual, isto é, os momentos em que o autor a tem como algo latente em seus artigos e naqueles em que ela se torna objeto explícito de discussão. Nossa proposição, então, é que a ideologia está em toda a sua obra, até mesmo quando Lefort discute um tema central em seus estudos: a invenção democrática, e isso significa dizer que a obra de Lefort nos parece espelhar a ideologia, no sentido de que ele a reflete em cada novo texto, em cada nova articulação de seus escritos na concepção de novos livros, além de se manter atento às interpretações ideológicas dos acontecimentos de sua época, em especial, Maio de 1968 na França.

Para o desenvolvimento dessas duas linhas de discussão, estruturamos nosso trabalho segundo uma perspectiva intrateórica, o que significa que o leitor não encontrará em nossas discussões um debate conceitual sobre a ideologia em que a 
perspectiva de Lefort seria confrontada às de outros autores. Esse debate não será feito, pois optamos por acolher a obra, participar de suas interrogações que, muitas vezes encontram-se subentendidas, para deixar vir pacientemente até nós o significado da ideologia no seu pensamento, uma vez que ela não é plenamente visível e captável em sua obra, exigindo um trabalho de leitura e releitura de seus escritos. Para tanto, foi necessário instaurar um percurso contínuo entre seus inúmeros artigos, onde foram feitos retornos, segundas e terceiras leituras que acabaram por estabelecer novas relações com o texto até que fosse possível compreender a inspiração que neles estava presente. Não pudemos nos apoiar em rotas prontas oferecidas pelos seus intérpretes, justamente porque eles partem do pressuposto de que a ideologia foi um tema explorado de maneira circunscrita pelo autor e nós a encontramos em toda a extensão de sua obra, o que exigiu de nossa parte a criação de um novo caminho de leitura e de interpretação. Permanecemos, então, no bojo da obra para a construção desse caminho, sempre em busca de adquirirmos maior familiaridade com os seus escritos, pois precisávamos compreender o que explicaria a sua escrita "hermética" (CHAUÍ, [1983] 1983, p. 9), "difícil", que "resiste a teses propagáveis", que "se furta ativamente", que é "complicada" (HABID, MOUCHARD e PACHET, 1993, p. 11), algo que se revela pelo entendimento da ideologia conforme discutiremos.

O primeiro capítulo compreende os movimentos de pensamento de Lefort, com o objetivo de explicitar o processo de construção de suas reflexões relativas à ideologia. Nós entrelaçamos a sua trajetória intelectual e política aos temas discutidos pelo autor e neles encontramos a ideologia de uma forma latente em seus pensamentos, no momento em que ele se volta para a literatura etnológica e realiza uma crítica aos mitos de sua época - o mito do partido como direção revolucionária, o mito da boa sociedade e o mito da revolução. Nesse sentido, procuramos compreender os embates teóricos vividos pelo autor como uma abertura em torno de novas questões que o levaram a discutir a ideologia.

O segundo capítulo abre-se com uma discussão em torno da preocupação assumida por Lefort em "relançar às pressas uma crítica" da ideologia (FH, [1974] 1979b, p. 296). Indagamos o que teria levado o autor a discorrer tão brevemente sobre ela em relação aos debates de sua época. Neste ponto, encontramos duas intenções: na primeira, argumentamos que não se tratava, para o autor, de apontar apenas que o debate sobre a ideologia havia se tornado um debate ideológico, como se bastasse 
descartá-lo, para, então, sair em busca de outra abordagem, pois Lefort procura compreender o que contribuiu para engendrar, neste mesmo debate, uma cegueira ideológica que se teria dado sobre o termo e cujo resultado final seria uma má compreensão sobre a democracia e o totalitarismo que passaram a fazer parte de diferentes construções discursivas em sua época. Ao mesmo tempo, encontramos uma segunda intenção arraigada à primeira: ele procura lançar uma crítica aos fundamentos do pensamento político, do discurso político, isto é, das "categorias que comandam a determinação do real" (FH, [1973] 1979b, p. 253), pois aqui estaria a chave que explicaria aquela cegueira. Nesse sentido, discutimos uma linha importante de reflexão sobre a obra de Lefort que está presente em seu trabalho da ideologia: o estabelecimento do pensamento do político visto a partir do nascimento do pensamento da política na sociedade histórica e do pensamento sobre a política, isto é, a ideologia. Esta discussão adquire maior inteligibilidade quando retomamos a ideia de que um pensamento da política nasce quando não há mais pensamento mítico, religioso a determinar o real. É na forma de sociedade moderna que o real é visado como tal, que se circunscreve um lugar para a política e, também, que nasce a ilusão do real - a ideologia.

O terceiro capítulo discute o significado da ideologia para Lefort, no qual veremos que ela é pensamento sobre a política, desdobrando-se com a finalidade de produzir um fundamento para a sociedade política como um todo, visto que esta é feita de uma indeterminação, da ausência de fundamentos. A ideologia tem a finalidade de produzi-los e, por meio de seus enunciados, interromper o trabalho da interrogação que nasce com a incerteza característica da sociedade moderna. Nesse sentido, há o surgimento de ideologias, as quais permanecem vinculadas à forma de sociedade como é possível refletir através de três tipos discutidos por Lefort: a ideologia burguesa, a totalitária e a "invisível".

Essa discussão leva-nos ao quarto capítulo que teve como ponto de partida a preocupação em compreender se há, na obra de Lefort, uma contradição inerente a suas próprias ideias quando o autor fala em ideologia e em "invenção democrática". Se a democracia é aquela marcada pela dissolução dos marcos de referência da certeza e a ideologia, por sua vez, preza pelo restabelecimento da certeza, então, sua ideia de revolução democrática poderia ser colocada em xeque. Esta questão, de um modo geral, parece estar ausente das interpretações realizadas pelos comentadores que têm permanecido em uma posição que enfatiza somente os traços de indeterminação 
democrática, sem perceber que Lefort também pensou o problema de sua determinação. Outros chegam a mencionar que o problema da ideologia está presente em suas reflexões, mas não chegam a se interrogar sobre qual é a "obra" da ideologia na democracia, conforme pretendemos discutir. Nesse sentido, veremos que, ao pensar a ideologia na democracia, Lefort remete-nos a um lugar em suas reflexões em que ela é vista como "dobra" democrática e, portanto, como aquela que cria representações ideológicas de si mesma.

O último capítulo discute como é possível criticar a ideologia, isto é, criar uma “abertura" para se chegar à verdade na democracia. Nós assumimos o ponto de vista de que esta forma de sociedade pode ser reinventada pelo trabalho de crítica às ideologias que está atrelada a uma ética da dúvida, ao trabalho da interrogação, do desvelamento e do deciframento como aquele capaz de desselar aquela sociedade política, engolfada por representações ideológicas entendidas como "fórmulas de democracia" que visam garantir um significado para a prática democrática. 


\section{CAPÍTULO 1 - Movimentos de pensamento}

\section{Introdução}

Percorrer a obra de Claude Lefort constitui um trabalho de reflexão que deve, necessariamente, acolher $\mathrm{o}$ enlace de suas interrogações filosóficas com os acontecimentos e debates políticos de sua época. Neste percurso, movidos pela exigência de compreender aquilo que levou o autor a falar, nós o encontramos em discussões e querelas intelectuais com as quais esteve envolvido, ao longo de sua trajetória, nos deparando com um caminho sinuoso, marcado por decepções, por rupturas $^{11}$, pela abertura de novas vias para o seu pensamento, por novas questões, tendo sido cunhado no bojo de um cenário intelectual no qual, podemos dizer, Lefort atuou de forma crítica em relação ao espírito de sua época. Referimo-nos a um pensamento que buscou posicionar-se criticamente à perspectiva marxista e ao ideário comunista, presente no cenário pós-guerra francês, e reabrir o problema do totalitarismo e da democracia, abordando a relação de imbricamento existente entre essas duas formas de sociedade.

Sua escrita, portanto, fez a experiência de um risco, ou seja, a todo o momento buscou os contornos de uma fala singular, no âmbito de um universo discursivo mais amplo, procurando criar uma passagem no mundo "agitado das paixões", em “desmanchar as armadilhas da crença", em "romper com ilusões comuns" (EL [1979f] 1979c, p. 13) a fim de subtrair-se e reiterar-se pela necessidade de realizar uma crítica à

\footnotetext{
${ }^{11}$ De acordo com Habib, Mouchard e Pachet (1993), Lefort pode ser considerado o artesão de uma mudança no cenário intelectual francês: a passagem do pensamento marxista à reavaliação da democracia e dos direitos do homem ocorrida nos anos 1980. Para tanto, esses autores consideram que foi de fundamental importância a sua ruptura com o marxismo. Quanto a esta ideia de ruptura, gostaríamos apenas de mencionar que no artigo de Mongin (1993) há certa cautela no uso dessa expressão como um qualificativo para o pensamento de Lefort, pois o autor considera que ele não buscou a "ruptura, o corte, a cisão" (MONGIN, 1993, p. 140), uma vez que não se separa de suas antigas crenças - marxistas, trotskistas -, a fim de colocar em relevo o seu próprio movimento de pensamento que sabe ser habitado pela contradição. Em nossa perspectiva, a postura de Lefort é aquela que procura expressar-se a si mesma como movimento de crítica, cuja abertura apenas foi possível no bojo de suas antigas crenças. Nesse sentido, a ruptura existiu, mas como sinônimo de "fenda", "brecha" à procura de "alguma coisa", pois para que o movimento crítico pudesse ocorrer, era imprescindível "romper com ilusões” (ibid. p. 141).
} 
ideologia de sua época. Trata-se, portanto, de uma fala encarnada nesta experiência, mostrando-se tenaz, rigorosa, até mesmo irônica, de modo que entrevemos que seu pensamento deixa-se habitar pela tensão, contendo o relevo de debates por ela frequentados.

Pelo que esboçamos, é possível entrever que suas reflexões se deixam habitar pelas questões e pelos discursos de seu próprio tempo, constituindo-se como um pensamento em debate. Nesse sentido, ao percorrermos sua obra, devemos, de imediato, estabelecer dois planos inter-relacionáveis: o plano político e o plano filosóficointelectual que se cruzam e recruzam ao longo de sua trajetória, de tal forma que a conjuntura, as questões colocadas pelos debates de cada período, o clima intelectual e político presente em cada momento não constituem apenas uma contextualização, um pano de fundo à frente do qual se delineia o seu pensamento. A obra de Lefort nos induz a um determinado tempo, a certo lugar e o designa para nós por meio de sua narrativa, arranja uma cena orquestrada por suas interrogações. Podemos percorrer os fatos fora dela, mas, certamente, deixaremos de compreender sua própria narrativa. Assim, além de nos revelar um entendimento sobre os movimentos de reflexão seguidos pelo autor, algo necessário para a compreensão de sua obra, consideramos que os aspectos políticos devem ser tomados como algo inserido em sua narrativa, mobilizados no plano de seu discurso.

Neste capítulo, apresentamos a relação entre estes dois planos, evidenciando os movimentos de pensamento de Lefort, ou seja, a abertura de novas vias interrogativas em seu discurso que o levam a refletir sobre o totalitarismo, a democracia e, particularmente, sobre a ideologia. Lemos sua obra como interrogação continuada, isto é, o seu discurso se faz em torno de aberturas constantes àquilo que o fez falar - os acontecimentos políticos, o discurso mítico e ideológico, a obra de pensamento. A palavra "movimento", nesse sentido, exprime a ideia de um encadeamento de interrogações que, ao longo de seu trajeto analítico, são semeadas, de modo que, ao abrir novos caminhos de reflexão, as questões suscitadas pelo pensamento do autor estão articuladas àquelas que as precederam e as que lhe sucederão. Trata-se de um grande discurso regido por um compasso que sabe ser habitado por novos impulsos, pelo risco de abrir novas questões, sem, no entanto, negligenciar aquilo que já foi adquirido em seu pensamento. A obra de Lefort, a nosso ver, não contempla etapas, cuja 
sequência conformaria um conjunto estanque de reflexões, cada qual se erigindo sobre a ruína do trabalho anterior, mas sim, movimentos interrogativos.

Visamos, seguindo uma sequência não necessariamente cronológica de seus escritos, nem mesmo uma sucessão ordenada de suas ideias, apresentar certos momentos de seu discurso que nos deixam descobrir uma relação entre aquilo que foi dito e aquilo que ainda está por nascer. Assim, seguimos o movimento de sua reflexão, considerando, em sua obra, os lugares onde o autor fez a experiência de uma abertura em torno de certas questões. Referimo-nos ao laço que mantém atadas suas interrogações localizadas nos limites da problemática marxista sobre o militantismo, sobre a ideia de partido, suas reflexões sobre a burocracia e sobre o totalitarismo, na URSS, que desenvolveu após sua saída do grupo Socialismo ou Barbárie em 1958, momento em que inicia outro movimento de reflexão: repensar a democracia. Seguimos um itinerário no qual Lefort deixou de ser militante, atuando em grupos e revistas para se constituir como um "pensador solitário" (HABIB, MOUCHARD \& PACHET, 1993, p. 7)

Consideramos que os movimentos de pensamento de Lefort foram comandados por tentativas constantes de se desprender das representações ideológicas de sua época, um trabalho de deciframento e desvelamento que contribui para a instituição e o engendramento de sua filosofia. Contra a ameaça do apagamento de seu movimento interrogativo, ele abre novas vias de reflexão para, então, "fazer pensar" como algo que demandou a desposse de si e das coisas. Este movimento inicia pela crítica aos mitos de sua época e no encontro com a etnologia, sendo marcado por rompimentos teóricos. Em grande medida, o autor deixa-se trabalhar pela linguagem de seus contemporâneos pelo marxismo e pelo trotskismo -, pois é do seu interior que ele encontra a saída, a abertura, uma vez que as certezas comuns que partilhou são vistas como enigmas a exigir suas interrogações. Este capítulo apresenta este movimento que, inicialmente, manteve a ideologia como algo latente, seguindo as reflexões do autor que o levaram até a uma discussão explícita da ideologia. 


\section{O círculo das crenças: da militância trotskista à saída do grupo Socialismo ou}

Barbárie

Entre os anos 1945 e 1948, Lefort realizou seus primeiros estudos, publicando seus primeiros artigos. Neste período, suas reflexões acontecem num círculo teórico estreito, dominado pela teoria marxista. No seu pensamento, instaura-se um movimento de inserção e de evasão em relação a este círculo, caracterizando um momento de errância, pois uma vez trotskista, deixará de sê-lo para devotar a este movimento e a Trotski diversas críticas no âmbito do grupo Socialismo ou Barbárie. Neste mesmo grupo, por sua vez, estabelecerá divergências em termos de linguagem e de perspectiva sobre o problema da organização revolucionária, o que o levará a criar outro grupo, o ILO (Informations et Liaisons Ouvrières), até deixar a militância e voltar-se para um trabalho exclusivo de reflexão teórica. Assim, Lefort que já fora considerado trotskista, marxista, prefere, então, localizar-se num lugar que não tem nome, alçando certa independência, dando-se a autoridade exclusiva do leitor e não mais mostrando fidelidade às diretrizes do partido trotskista ou àquelas pronunciadas por camaradas seus nos grupos em que atuou.

Com relação a estes movimentos de inserção e de evasão do círculo das crenças, eles marcam um momento em que Lefort adquire consciência sobre os limites inerentes à teoria de Marx com relação ao entendimento de novas questões surgidas em função dos acontecimentos de caráter antitotalitário ocorridos na época - Hungria, Polônia, Tchecoslováquia -, assim como em relação ao uso feito desta teoria por marxistas, o que, na sua perspectiva, favorecia a não compreensão efetiva do regime instaurado na URSS.

Assim, Lefort instaura, em seu discurso, um movimento de crítica à corrente marxista. Ele se serve de sua militância política, retirando de tal experiência importantes lições. A sua vivência no interior do partido trotskista - o PCI (Partido Comunista Internacionalista) -, possibilitou-lhe uma aguçada compreensão a respeito da lógica e do funcionamento interno de um partido, no que se refere ao entendimento sobre as condições responsáveis pela instauração de uma microburocracia em seu interior. Como veremos, boa parte das críticas de Lefort ao militante, ao partido, particularmente ao partido no regime totalitário, tanto no que concerne à sua lógica interna, como ao fato 
de deter um saber, uma ideologia capaz de assegurar o funcionamento do regime, são beneficiadas por aquela experiência.

Outra questão importante a ser considerada aqui relaciona-se às considerações de Lefort sobre a perspectiva da esquerda em relação ao acontecimento totalitário. Neste período, verificaremos que suas críticas organizam-se de modo a apontar para a existência de uma função mítica inerente ao discurso da esquerda que inclui trotskistas, comunistas e membros do grupo Socialismo ou Barbárie. Ele considera que todos os documentos e testemunhos surgidos neste período foram vistos como meros "acidentes", deixando intacta a boa imagem do regime. Suas reflexões, portanto, foram desenvolvidas, neste período, com vistas a explicitar que o regime soviético não teria sido um acidente. Da mesma forma, chega à conclusão de que o economicismo exacerbado dos marxistas impedia a plena compreensão de certos traços do regime totalitário, algo que o levará, então, a romper com esta corrente e buscar novos elementos teóricos para pensar o totalitarismo.

O que se discutirá abaixo são os estudos de um jovem revolucionário, participante do círculo de reflexões marxista, nos quais se percebe o esforço para a emancipação dos seus aspectos mais doutrinários.

\subsection{Mitologia do partido: crítica à noção de partido e direção revolucionária}

As reflexões desenvolvidas por Lefort, nos anos 1950, relacionam-se ao problema da organização revolucionária. Sua principal questão subscreve-se da seguinte forma: "a luta do proletariado exige ou não a construção de uma direção ou de um partido?” (EL [1958] 1979c, p. 98). Contrário ao posicionamento da maior parte dos grupos de esquerda de sua época - comunistas, trotskistas e membros do grupo Socialismo ou Barbárie (SB) ${ }^{12}$-, cujas reflexões e ações pautavam-se pela necessidade de construir um partido do proletariado, Lefort posiciona-se frente a esta "teoria da direção", sustentando a tese de que o proletariado é sua própria teoria, ou seja, que está em condições de pensar, articular e organizar-se autonomamente. Suas argumentações,

\footnotetext{
12 A principal divergência instaurada no grupo Socialismo ou Barbárie diz respeito ao problema da organização revolucionária. Enquanto uma parte do grupo buscava definir a atividade revolucionária no quadro de um partido de tipo novo, outra parte visava a experiências autônomas.
} 
neste período, inseridas como estão no círculo de análise marxista, não descartam a importância da rearticulação da classe trabalhadora, do ideário e do papel revolucionário do proletariado, mas procuram criticar um elemento-chave: a direção partidária.

Para que possamos reconstituir suas reflexões, devemos considerar brevemente que o debate girou em torno dos postulados estabelecidos por Karl Marx e Friedrich Engels a respeito da constituição de um partido da classe proletária presente na obra $O$ Manifesto comunista (MARX e ENGELS, 2010). Nas reapropriações produzidas por Lênin e Rosa Luxemburgo, o partido é tomado como instrumento forjado pelo proletariado para a necessária luta de classe, de modo a ser considerado como um esforço desta classe para pensar sua luta sob uma forma universal. Na perspectiva de Lefort, por sua vez, o partido nada mais é do que um corpo relativamente estrangeiro à classe, composto por um quadro de militantes dela separado, se constituindo e se desenvolvendo à sua distância, de maneira disciplinada e centralizada. O partido se apresenta, por sua vez, autoritariamente como a direção da classe, cujo programa não é elaborado por trabalhadores, mas sim por intelectuais pequeno-burgueses que, pelo fato de não estarem no processo de produção, em virtude de sua cultura e de seu modo de vida, tornam-se capazes de se dar à preparação teórica e prática da revolução. O proletariado, por sua vez, se representa por meio de uma direção, isto é, de um corpo separado. A revolução fica, então, a cargo do revolucionário profissional que toma a frente da classe trabalhadora, assumindo a tarefa que a ela caberia cumprir. Para Lefort, tal proposição demonstra que o único objetivo a ser perseguido é a revolução, traduzida pelo estabelecimento do partido como órgão do poder e não o poder proletário, o que contribui para endossar uma concepção abstrata de revolução.

Com relação à estrutura interna do partido, Lefort constata que nele se produz uma divisão interna entre dirigentes e simples militantes, favorecendo a hierarquização de funções, bem como a especialização da atividade política. A lógica ocorre de tal forma que, enquanto cabe à classe dirigente a tomada de todas as decisões, aos militantes resta o encargo de apenas produzir ratificações, o que contribui para fundar no interior do partido uma espécie de "democracia da ratificação" (EL, [1958] 1979c, p. 100), levando a base a se acostumar à inércia política. Tendo em vista essa divisão de tarefas, Lefort constata que os dirigentes nada mais são do que "camaradas competentes" (ibid., p. 100), dispostos a "bem dirigir" a massa trabalhadora, erigindo-se como detentores de um saber capaz de introduzir "de fora" a consciência política dos 
trabalhadores, dirigindo suas ações conforme a plataforma do partido. O "camarada competente" é considerado aquele que "assimilou o programa, que representa o 'Centro', que possui a ciência da política revolucionária, que tem o poder de se 'elevar ao nível das tarefas universais da revolução"” (ibid., p. 106).

Tais indagações sobre a lógica e o funcionamento interno de um partido estão vinculadas ao período em que Lefort militou no PCI, um partido trotskista na França. Seu aprofundamento teórico, portanto, não se dissocia desta experiência ocorrida no seio do trotskismo, cujas lições lhe servem como apontamentos elucidativos em sua argumentação, como vemos no trecho abaixo, em que Lefort afirma que o PCI mostrava-se, em vários sentidos, à distância da vivência e da luta estabelecida pelos trabalhadores em relação ao sistema de exploração. Tal fato é constatado pelo quadro de militantes, preocupados apenas em tirar vantagens no interior do Partido ou, ainda pelo modo de apreensão da prática trabalhadora, considerada apenas pelo ponto de vista do Partido que a avaliava a fim de estabelecer até que ponto serviria ou não a seu projeto político. Registramos também que o Partido nominava-se como o "partido do proletariado", sua "direção irrevogável”, julgando que a revolução seria o simples cumprimento de seu programa.

Por minha parte, este aprofundamento teórico ia de par com uma experiência que eu tive no seio do partido trotskista, cujas lições me parecem claras.

O PCI, no qual militei até 1948, não participava em nada do sistema de exploração. Seus quadros tiravam privilégios de sua atividade no partido. No seu seio, encontramos elementos animados de uma "boa vontade revolucionária" evidente, e conscientes do caráter contra-revolucionário das grandes organizações tradicionais. Formalmente, uma grande democracia reinava. Os organismos dirigentes eram regularmente eleitos nas assembleias gerais; as quais eram frequentes, os camaradas tinham a liberdade para se reunir em tendências e de defender suas ideias nas reuniões e nos congressos (eles podiam se exprimir nas publicações do partido). Portanto, o PCI se comportava como uma microburocracia e nos aparecia como tal. Sem dúvida, dava lugar a práticas condenáveis: trucagem de mandatos fora dos congressos, manobras efetuadas pela maioria para assegurar ao máximo a difusão de suas ideias e reduzir aquela das minorias, calúnias diversas para desacreditar o adversário, chantagem em torno da destruição do partido cada vez que um militante se encontrasse em desacordo sobre certos pontos importantes do programa. Com respeito às lutas trabalhadoras, o ponto de vista da organização predominava absolutamente. Em consequência disso, as lutas eram sempre interpretadas segundo este critério: em quais condições elas seriam favoráveis ao reforço do partido? Se fosse identificada uma vez por todas com a Revolução mundial, o partido se prestava a manobras para que elas fossem úteis a seu desenvolvimento. (EL, [1958] 1979c, p. 99-100) 
As conclusões a que chega Lefort sobre o PCI, ele as estende ao Partido Comunista, o grande alvo de suas considerações críticas neste período e nos anos 1970. Dessa maneira, seguindo o referencial marxista, Lefort considera o partido uma "superestrutura" (EL, [1952a] 1979c, p. 66), distanciada da prática

[...] tanto o PCI como o PC viam no proletariado uma massa a ser dirigida. Ele pretendia somente bem dirigi-la. Ora, esta relação que o partido entretinha com os trabalhadores - ou melhor, que ele desejaria entreter, porque de fato ele não dirigia nada - encontrava-se transposta ao interior da organização entre o aparelho de direção e a base. A divisão entre dirigentes e simples militantes era uma norma. Os primeiros esperavam dos segundos que os escutassem, que discutissem proposições, que votassem, difundissem o jornal e colassem cartazes. Os segundos, persuadidos de que era preciso para a cabeça do partido camaradas competentes, faziam o que se esperava deles. A democracia estava fundada sobre o princípio da ratificação. Consequência: assim como na luta de classe o ponto de vista da organização predominava, na luta no interior do partido, o ponto de vista do controle da organização era decisivo. Ao mesmo tempo que a luta revolucionária se confundia com a luta do partido, este se confundia com a luta dirigida pela boa equipe. $\mathrm{O}$ resultado era que os militantes se determinavam sobre cada questão segundo este critério: o voto reforça ou, ao contrário, arrisca enfraquecer a boa equipe? (EL, [1958] 1979c, p. 100-101, grifos do autor)

Tal é o ponto de vista da vanguarda, dos grupos de esquerda entre os quais se incluíam membros do grupo Socialismo ou Barbárie que postulavam a criação de um partido do proletariado, sem perceber que estavam, na verdade, endossando a criação de "um instrumento privilegiado de formação e de seleção da burocracia" (ibid., p. 108) ${ }^{13}$. Devemos salientar que, nas reflexões realizadas por Lefort sobre a burocracia, o partido é entendido como a instituição burocrática típica (EL, [1960b] 1979c, p. 294), constituindo-se como antítese da democracia, justamente pela criação no seu interior de um grupo dirigente, pela hierarquização de funções e pela tomada de decisões voltadas para o interesse do partido.

Mas, de onde vem então que se possa falar do partido de massas como de uma instituição burocrática típica? (...) é porque nós distinguimos nele um setor específico onde as funções são hierarquizadas em razão de uma participação de fato no poder, onde são tomadas as decisões que interessam à orientação do partido na ausência de todo controle da base, onde as responsabilidades são repartidas por via autoritária, onde a disciplina da organização leva vantagem sobre o livre exame das decisões, onde se institui uma continuidade de papéis, de condutas e de pessoas que tornam uma minoria dirigente praticamente imóvel. (EL, [1960b] 1979c, p. 294)

\footnotetext{
${ }^{13} \mathrm{Um}$ dos principais eixos de análise presente no grupo Socialismo ou Barbárie refere-se ao problema da burocracia, pensada como classe e como uma tendência a alcançar proporções globais. Neste capítulo, procuramos discutir suas características em relação ao partido e em relação ao regime totalitário instaurado na URSS, de modo a demonstrar que sobre esta questão, também, Lefort desenvolve sua análise no plano de uma crítica à perspectiva marxista e em relação aos sociólogos de sua época.
} 
No interior do partido, atuam militantes profissionais responsáveis por manter aquela estrutura cristalizada, sagrada, imóvel, fazendo do partido sua propriedade privada. Toda a atividade desenvolvida por este burocrata conservador resume-se a intervir na luta social conforme seu próprio princípio, não estando aberto a uma discussão ideológica, pois corre o risco de se transformar, de se deslocar. Ao mesmo tempo, todo o seu ativismo não passa de uma agitação febril e vã (cf. EL, [1960b] 1979c, p. 296), já que se resume a assembleias regulares do partido, à multiplicidade de reuniões, de encontros, de festas e de comemorações.

Este conservantismo inspira todas as relações interburocráticas: o culto da autoridade, a vontade de controlar todos os níveis de atividade dos militantes, o valor de prestígio reconhecido às funções de responsabilidade são traços muito bem conhecidos para que valha a pena sublinhar. (EL, [1960b] 1979c, p. 297)

Tendo em vista tais considerações, para Lefort o partido deve ser destruído, uma vez que qualquer tentativa de reforma, disposta a lhe conferir atributos democráticos que, na verdade são incompatíveis com sua essência, significa o mesmo que cair numa "mistificação" (EL, [1958] 1979c, p. 108). Em outras palavras, Lefort considera que permanecer na máxima: “o poder de classe é inviável se não houver um partido" equivale à instauração do "mito do partido", tornando-se um impeditivo para toda e qualquer reflexão disposta a procurar repensar a experiência proletária, vendo-a sob novas expressões de luta. Assim, para que se possa pensar a via revolucionária, Lefort preconiza o rompimento com a "mitologia do partido" (ibid., p. 113) e com o "edifício ilusório" construído sobre a ideia de "direção revolucionária" como é o caso dos grupos de esquerda a compor a vanguarda em sua época.

$\mathrm{Na}$ visão de Lefort, nenhum partido deve assumir o que cabe ao proletariado resolver, ou melhor, a organização da classe proletária não requer um partido, devendo ocorrer espontaneamente. Ainda que o partido contenha um programa antiburocrático, as lutas devem ser decididas e controladas por aqueles que as vivenciam, sem que haja, portanto, a criação de um corpo funcionando segundo leis próprias.

Nesta linha argumentativa, não se propõe que a figura do militante seja extinta, mas apenas a inversão de seu papel: de dirigente passa a subordinar-se ao movimento trabalhador, de modo que cumpre o dever de ajudá-lo na luta de classe, pois seu aporte teórico e sua cultura têm o mérito de auxiliar aquele movimento. Seu objetivo, portanto, 
deve ser sustentar, amplificar e esclarecer a classe trabalhadora pela busca e propagação de informações e conhecimentos, além de procurar colocar os trabalhadores em contato uns com os outros. Nos termos desta atuação, o militante deve propagar a ideia de que são os próprios trabalhadores os responsáveis pela reflexão e pela organização de sua luta $^{14}$.

[...] os militantes não são, não podem, nem devem ser: uma Direção. Eles são uma minoria de elementos ativos, vindos de camadas sociais diversas, reorganizadas em razão de um acordo ideológico profundo, e que se empregam a ajudar os trabalhadores em sua luta de classe, contribuir para o desenvolvimento desta luta, dissipar as mistificações entretidas pela classe e pelas burocracias dominantes, propagar a ideia de que os trabalhadores, se eles querem se defender, estarão em condições de tomar, eles mesmos sua sorte em suas mãos, de se organizarem a si mesmos frente à escala da sociedade e àquela do socialismo. (EL, [1958] 1979c, p. 110-111, grifos do autor)

Ao desfazer o mito do partido, pela pressuposição de que o proletariado não deve ser dirigido, verificamos que Lefort quer deslocar o eixo de reflexão e de atuação estabelecido em sua época, o qual se centrava, conforme argumentamos, na procura por programas, regras e modos de funcionamento a serem aplicados na constituição de um novo partido ou de sua reforma. Trata-se, por sua vez, de voltar-se para uma compreensão sobre o modo como o proletariado dispõe de sua experiência, sobre o sentido que atribui à sua prática e não aquilo que deveria ser-lhe imposto pela direção.

A fim de resgatar esta "experiência proletária", Lefort realiza outro movimento crítico, tecendo suas reflexões em relação à "mistificação ${ }^{15}$ do movimento dos trabalhadores" (EL, [1952a] 1979c, p. 71). Em sua perspectiva, tal mística é alimentada por um "pseudomarxismo", capaz de converter a teoria da luta de classes desenvolvida por Marx em uma ciência puramente econômica, atribuindo leis como as da ciência física à dinâmica de classe. Este viés economicista contribui para escamotear o papel das classes e dos homens, visto que reduz a ação do proletariado a uma atitude reativa, determinada pela estrutura econômica quando, na verdade, ela contém em si uma experiência acumulada.

\footnotetext{
${ }^{14}$ Lefort destaca que a publicação de um jornal ou de um boletim sem periodicidade seria o meio principal para a realização de tal atividade militante. Tal proposição inscreve, em 1958, seu novo projeto de atuação após sair do grupo Socialismo ou Barbárie, voltada para o levantamento de informações e o estabelecimento de ligações entre as experiências dos trabalhadores (EL, [1958] 1979c, p. 113) através do grupo ILO (Informations et Liaisons Ouvriéres).

${ }_{15}$ Lefort emprega o vocábulo mystification que designa o ato ou propósito destinado a mistificar, significando enganar alguém abusando de sua credulidade, diferentemente de mythifier que significa a instauração de um mito. Conferir os verbetes mystification e mythifier em Le Robert de poche (2008).
} 
Seria absurdo interpretar o desenvolvimento do movimento trabalhador sem colocá-lo constantemente em relação com a estrutura econômica da sociedade, mas querer reduzi-lo é se condenar a ignorar quase toda a conduta concreta da classe. A transformação, em um século, da mentalidade trabalhadora, dos métodos de luta, das formas de organização, quem se aventuraria a deduzi-las do processo econômico? (EL, [1952a] 1979c, p. 73)

O "pretenso materialismo econômico" cumpre, então, o papel de mistificação, na medida em que reduz seu entendimento sobre a classe trabalhadora à sua única função econômica.

Vendo-a como a expressão de uma ideologia do comando, capaz de converter o proletariado em uma massa submetida a leis, em um agente de sua função econômica, Lefort contrapõe-se e afirma que não são os atributos econômicos os responsáveis por desenvolver o sentido de classe ao proletariado e sim "a experiência que se efetua ao nível das relações de produção e sobre a percepção que têm dela os trabalhadores" (ibid., p. 81).

Lefort procura, então, estabelecer um tipo de reflexão sobre o comportamento dos trabalhadores que não deve se assemelhar àquela desenvolvida por "pseudossociólogos" e "pseudopsicólogos" (ibid., p. 85), munidos do "conceito de adaptação social", de um aparelho de investigação estatística, preocupados em aplicar questionários para coletar informações com vistas a melhor adaptar o trabalhador em suas funções ${ }^{16}$. Contrário aos postulados da Sociologia do Trabalho desenvolvida nos Estados Unidos, Lefort procura "restituir o sentido" conferido pelo trabalhador à sua prática por meio de uma interpretação de seus testemunhos, narrativas de vida, fatos da experiência individual que, na sua ótica, fornecem ensinamentos sobre a vida social. Ao buscar os testemunhos, por sua vez, Lefort está atento à impossibilidade de

[...] definir o que o proletariado é na sua realidade, uma vez rejeitadas todas as representações que se fazem de sua condição quando ele é percebido através do prisma deformador da sociedade burguesa ou dos partidos que pretendem exprimi-la. (EL, [1952a] 1979c, p. 90, grifo do autor)

Isso implica em buscar a fala do trabalhador, sua narrativa, seu testemunho deixando, portanto, de defini-la à distância como o faz o dirigente partidário na

\footnotetext{
${ }^{16}$ Lefort condena as enquetes feitas junto aos trabalhadores por indivíduos exteriores a ela, sejam eles cientistas - sociólogos ou por quadros do partido.
} 
elaboração de artigos e programas no partido. Ele está consciente também que o próprio testemunho é perpassado por ideologias. Assim, uma análise concreta do proletariado deve descrever a situação econômica na qual se encontra a classe e a influência que ela tem sobre sua estrutura, atentando-se para as condições de trabalho, de vida da classe (os métodos de exploração, a produtividade, a duração do trabalho, os salários, as possibilidades de emprego), além de desenvolver uma abordagem "tipicamente subjetiva" (EL, [1952a] 1979c, p. 82), visando a todas as expressões da consciência proletária ou o que se entende ordinariamente pelo termo "ideologia"17 como o anarquismo, o reformismo, o bolchevismo e o stalinismo que representam momentos daquela consciência ${ }^{18}$. Dessa maneira, Lefort considera que tais ideologias operam uma “deformação da classe trabalhadora" (ibid., p. 84), posto que é obra de uma minoria dirigente, exterior à vida real da classe trabalhadora.

Ora, se há sempre uma separação entre isto que é vivido e isto que é elaborado, transformado em tese, esta separação tem uma amplitude particular no caso do proletariado. É, então, que ela é uma classe alienada, não somente dominada, mas totalmente excluída do poder econômico e, dessa forma, encontra-se na impossibilidade de representar um estatuto qualquer - o que não significa que a ideologia não mantenha relação com esta experiência de classe, mas que se tornando um sistema de pensamento, ela supõe uma ruptura com esta experiência e uma antecipação que permite a fatores não proletários exercer influência. (EL, [1952a] 1979c, p. 83)

Voltar-se para a experiência explícita do proletariado implica também uma abordagem histórica, capaz de apreender sua experiência sob suas diversas formas - em revoluções, formas de resistência ou de organização como associações, sindicatos, partidos, comitês de greve ou de luta - constituindo uma experiência progressiva ligada à evolução das formas econômicas e políticas da sociedade capitalista. Nesta perspectiva, no lugar de examinar-se do exterior a situação e o desenvolvimento do proletariado, deve-se procurar restituir do interior sua atitude em face de seu trabalho e da sociedade. Dessa maneira, Lefort quer compreender a capacidade de invenção e o poder de organização presente no interior da classe trabalhadora. Apreender

\footnotetext{
${ }^{17}$ Neste momento, devemos considerar que a ideologia para Lefort é vista como "sistema de pensamentos que supõe uma ruptura com a experiência e uma antecipação que permite a fatores não proletários exercer influência" (EL, [1952a] 1979c, p. 83). Nesse sentido, ele emprega o termo com o objetivo de compreender as ideias dominantes que são detidas pela classe proletária, os quais são veiculados por dirigentes comunistas. No próximo capítulo, veremos que Lefort pensará a ideologia sob outra perspectiva.

${ }^{18}$ Para Lefort, trata-se, então, de ideologias produzidas por uma fração da vanguarda militante associada a uma intelligentsia separada da classe. O bolchevismo constitui uma racionalização da condição trabalhadora (EL, [1952a] 1979c, p. 83).
} 
teoricamente o proletariado implica, então, "participar de sua história”, analisando suas atitudes

[...] são as atitudes trabalhadoras que nos interessam, algumas vezes, de fato, exprimidas em opiniões, mas frequentemente também desfiguradas, mas em todo caso, mais profundas e necessariamente mais simples que aquelas das quais procedem; assim, seria um desafio manifesto querer induzir a partir de quaisquer testemunhos individuais as opiniões do proletariado sobre a URSS ou mesmo sobre uma questão tão precisa quanto aquela do leque dos salários, mas nos parece muito mais fácil perceber as atitudes com relação ao burocrata, espontaneamente adotadas no seio do processo de produção. (EL, [1952a] 1979c, p. 89, grifo do autor)

Todo este esforço em buscar os testemunhos ${ }^{19}$ reside, portanto, na constatação de que o partido encontra-se isolado, não respondendo aos problemas colocados pela vida social real, constituindo uma casta burocrática devotada a uma idealização do regime soviético. Atento a estes traços, Lefort ainda sublinha o estabelecimento com o stalinismo de uma nova função para o partido: "ele é o agente essencial do totalitarismo moderno" (EL, [1956] 1979c, p. 190).

Chegamos, assim, ao ponto central de sua reflexão nos anos 1950: a URSS como forma de sociedade totalitária. Para desenvolver tal perspectiva, seu discurso retoma a mística produzida por grupos de esquerda - trotskistas, comunistas - de modo a justificar os erros cometidos por Stalin, além dos de direita - burgueses - contribuindo para elevar uma cortina de ferro, impedindo, por sua vez, a plena compreensão de seus traços.

No próximo item, procuramos retomar suas reflexões sobre o partido, a burocracia e o militantismo, no âmbito de sua análise sobre o totalitarismo, realizada nos anos 1950, de modo a desvelar a constituição de suas análises frente àquelas representações ideológicas.

\subsection{Crítica à URSS como mito e "diálogo de surdos"}

O estabelecimento do partido totalitário na URSS é considerado por Lefort como fruto de um processo iniciado com a Revolução de 1917. As políticas adotadas

\footnotetext{
${ }^{19}$ Os testemunhos adquirem grande relevância na ótica de Lefort, adquirindo um espaço importante na revista Socialismo ou Barbárie. Lefort preocupou-se com os testemunhos relativos à URSS, tal como veremos na próxima subseção e considerou os relatos de Kravchenko e de Ciliga em sua reflexão sobre o totalitarismo nos anos 1950 e nos anos 1970 os de Soljenitsin.
} 
por Lênin e acalentadas por Trotski, forjadas de modo a separar o partido dos comitês de fábrica, proclamando firmemente a necessidade de uma rigorosa centralização de todas as responsabilidades em suas mãos lhe são elucidativas. No grande debate sindical de 1920, por exemplo, Trotski já formulava publicamente o programa totalitário do partido ao requerer a obediência absoluta de todos os grupos sociais à direção do partido, bem como a subordinação estrita dos sindicatos, estigmatizando todas as oposições, de modo que toda e qualquer defesa de interesses por parte da classe trabalhadora contra o Estado eram consideradas como absurdas e responsáveis por colocar em xeque a causa revolucionária do regime.

Lefort destaca que, naquele momento, as medidas "totalitárias" tomadas por estes dirigentes são vistas como provisórias e impostas pela conjuntura, considerados como "simples artifícios improvisados para manter a existência da URSS" num período marcado por uma guerra civil (EL, [1956] 1979c, p. 171).

Os dirigentes, então, consideram que as decisões de caráter totalitário foram tomadas em virtude das circunstâncias, devido à depreciação do Estado. Com o stalinismo, por sua vez, Lefort considera que uma escolha é feita, a escolha por uma certa fórmula $^{20}$ do socialismo que conterá todos os traços estabelecidos pelas políticas anteriores, contribuindo para ratificar, legalizar, cristalizar uma proposta ideológica. Como destaca Lefort, de um ponto de vista ideológico

[...] a fórmula do socialismo, em um único país, vem legalizar o estado de fato; a separação do Estado e das massas, a concentração de toda autoridade entre as mãos de uma direção única. Todos os traços provisórios da nova sociedade e que não tinham seu sentido pleno a não ser em função de uma nova política do conjunto orientado em direção ao socialismo são ratificadas como se elas constituíssem em si mesmas a essência do socialismo. (EL, [1956] 1979c, p. 172, grifo do autor)

Nesse sentido, o stalinismo apresenta-se como continuador do leninismo, representando-se dessa forma, isto é, erigindo em valores o que se constituía apenas

\footnotetext{
${ }^{20}$ Esta palavra utilizada por Lefort foi objeto de discussão por parte de Pierre Pachet (1993), o qual a relaciona a duas outras expressões: "reformulação" e "informulável". A "fórmula" é linguagem condensada, o resumo de um pensamento para favorecer a repetição, sendo sinônimo de fechamento, pois ela afasta a interrogação. Para o autor, Lefort é aquele que buscou interpretar a "fórmula", pois ela é feita de coisas não ditas, de mistérios, compromissos, conflitos que concorreram para o seu nascimento. Um exemplo dado pelo autor se refere às discussões feitas por Lefort sobre a fórmula de Robespierre: "eu sou o escravo da liberdade" e "despotismo da liberdade", em que a afirmação absoluta da liberdade se confunde com a sua negação, contendo representações contraditórias. Para a discussão que temos feito da ideologia, retomaremos mais a frente a ideia de que a "fórmula" faz parte da linguagem ideológica, porque exerce um fascínio, cria as condições para que o discurso possa se repetir indefinidamente, cristalizando o pensamento.
} 
como medida política. Simultaneamente, deixa de ser realizada uma reflexão teórica sobre o marxismo, no sentido de que "as medidas do Estado tornam-se socialistas pela única razão de que elas eram leninistas" (ibid., p. 173). Em relação ao discurso de Trotski, devotado a sufocar toda manifestação de interesse contrário ao regime, com Stalin este discurso deixará de ocorrer, trabalhando aquele discurso em ações práticas e efetivas.

No período stalinista, portanto, dá-se a constituição plena do Estado Totalitário uma vez que Stalin torna-se o líder a concentrar em suas mãos todos os poderes, atuando em prol de uma reforma em toda a sociedade soviética, com o objetivo de estabelecer um poder industrial, fundado sobre um planejamento econômico mantido por planos quinquenais. Registramos, com relação a este período, a fase de terror, marcada pelos "Grandes Expurgos", com a finalidade de expulsar e executar muitos dos opositores ao seu regime. Um recurso fundamental neste processo foi a constituição de um sistema de campos de concentração na Sibéria, chamado Gulag.

A função histórica de Stalin é objeto de questionamento por Lefort, o qual argumenta que ela deve ser compreendida como fundada em seu papel político e não em sua personalidade. Segundo ele, algumas interpretações relativas ao stalinismo tiveram o efeito de criar uma "cortina de ferro", impossibilitando o pleno entendimento de seu papel histórico, uma vez que a sociedade soviética passou a ser vista como "sociedade sem corpo", confundida com a pura Vontade de Stalin, considerado pela esquerda comunista como infinitamente bom, fundando um culto à sua figura; e, pela direita, como infinitamente mau, apresentando-o como o tirano brutal ${ }^{21}$. Estes "delírios", conforme elucida Lefort, se entrecruzam, fundando o "mito de um sistema perfeitamente coerente" (EL, [1956] 1979c, p. 156), designado pela direita como totalitarismo absoluto e pela esquerda como socialismo, mas sempre mantendo uma diferença em relação às sociedades capitalistas.

Delírio burguês que converteu a URSS em uma máquina infernal com juntas perfeitamente lubrificadas, moendo toda diferença social e individual e fabricando sob as ordens de um Gengis Khan reencarnado um homem-robô encarregado de arrasar a humanidade. Delírio "comunista" moldando a imagem ideal do paraíso socialista, no

\footnotetext{
${ }^{21} \mathrm{O}$ trotskismo também pode ser incluído neste delírio, mantendo-se naquele mito, uma vez que na obra Minha Vida, de Trotsky, são selecionados alguns aspectos da personalidade de Stalin, particularmente sua mediocridade intelectual e seu temperamento astuto, para fazer concordar com sua propositiva de que a burocracia é uma casta parasitária, desprovida de toda significação histórica. Stalin é visto como um "falso grande homem" e o partido que ele encarna, um pseudopartido.(ibid., p. 169-170)
} 
qual os contrastes mais grosseiros da realidade se modificam em harmonias complementares. Não é demais observar que estes delírios opostos se entrecruzavam curiosamente no mito de um sistema perfeitamente coerente designado como totalitarismo absoluto ou como socialismo, mas sempre apresentado como radicalmente diferente dos sistemas capitalistas conhecidos por nós. O trotskismo, é verdade, apresentou um panorama contrastado, mas, se contentando em implantar a imagem do totalitarismo sobre aquela do socialismo, acumulou no seu próprio mito as ficções precedentes. (EL, [1956] 1979c, p. 156)

Tais interpretações, na visão de Lefort são responsáveis por fundar uma "mitologia stalinista", em que os olhares voltam-se exclusivamente para a personalidade de Stalin, contribuindo para manter intacta a imagem do regime. Assim, todos os erros cometidos no âmbito do regime são atribuídos, após a morte de Stalin, à sua pessoa. De modo que, se em vida, Stalin era positivamente cultuado, num ritual que o colocava como a expressão da sociedade socialista, abarcando uma conjunção completa entre os aspectos subjetivos das virtudes de sua personalidade e objetivos, relativos à esfera política e econômica; ao dar-se sua morte, todos os vícios de Stalin passam a ser evidenciados num rito negativo, de tal forma que sua caricatura monstruosa é exaltada e sublinhada a sua incapacidade de resposta à sociedade, contribuindo para torná-lo, em seu interior, um fenômeno absurdo. O novo dirigente, Khrushchov, ao procurar estabelecer uma nova política pelo questionamento das ações passadas, ressalta que somente Stalin é que está em causa, o que favorece a operação de dissimulação do regime totalitário instaurado na URSS.

O "afrontamento da mitologia stalinista" (EL, [1956] 1979c, p. 158), além de possibilitar a Lefort uma compreensão sobre o que ela visa recobrir e dissimular, tanto no passado stalinista, como no presente pós-stalinista da URSS, também lhe permite lançar uma nova interpretação. Contrário às anteriores, Lefort considera que Stalin encarnou uma "forma do poder" fundada na concentração de todas as funções políticas, econômicas, jurídicas. Ele era a autoridade que subordinava todas as atividades à sua direção, impondo-lhes um modelo, controlando os indivíduos e grupos pela eliminação física de todas as formas de oposição. O stalinismo, por sua vez, é definido por Lefort como um "fenômeno ideológico e um fenômeno social, um sistema de pensamento e um sistema de ação" (ibid., p. 163)

Enquanto sistema de exploração, ele estabelece um importante parentesco com as sociedades capitalistas ocidentais, na medida em que mantém uma ditadura e 
grosseiras desigualdades sociais, em que o proletariado é considerado como detentor do poder, ao mesmo tempo em que dele é totalmente despossuído, o que desfigura seu caráter socialista. Nesse sentido, para Lefort, o regime soviético não implicou a organização de um novo regime, visto que não operou o ultrapassamento radical das contradições do sistema capitalista, isto é, a passagem da sociedade para uma nova etapa em que o modo de produção não se encontre mais calcado na exploração e no domínio de uma classe.

Na URSS como em outros lugares se manifesta o peso decisivo das classes exploradas; como em outros lugares a conduta da classe dominante se revela determinada pela preocupação em assegurar, por novos meios, uma dominação à qual não basta mais a simples coerção e, como em outros lugares, o proletariado se encontra afrontado a tarefas cuja fórmula, inscrita em oposição ao fracasso capitalista, se elabora progressivamente. (EL, [1956] 1979c, p. 156)

O stalinismo, portanto, exerceu um papel extraordinário, no sentido de produzir grandes mudanças econômicas e sociais em cujo término, consolidou-se uma nova estrutura de classes, despossuindo o proletariado de todo o poder, mantendo-o subordinado a tarefas de produção que lhe determinava a nova economia planificada.

Os trabalhadores são totalmente estrangeiros na URSS com relação à direção da produção; eles fornecem sua força de trabalho e se chocam com um aparelho de Estado com o qual eles nada têm a ver. Não há nem mais, nem menos democracia trabalhadora na URSS que nos Estados Unidos; nos dois casos os trabalhadores estão situados, com relação aos meios de produção, em antagonismo com uma camada dirigente.(...) A planificação é a planificação da classe dirigente; a concentração dos meios de produção é concentração entre as mãos de um Estado que, ele mesmo, está ligado a uma classe dirigente. (EL, [1948] 1979c, p. 130)

O terror encontra-se no fundamento da vida social soviética, visto como necessário para a transformação social encarnada pelo partido. O terror funda e domina o empreendimento totalitário, exercendo-se sobre proprietários privados, contra o proletariado e as novas camadas dominantes na URSS. As repressões fundadas em expurgos, durante o período stalinista, ocorrem para evitar o perigo gerado pela mobilidade social presente no regime, garantindo a unidade, a coesão e a ordem do regime ${ }^{22}$.

\footnotetext{
${ }^{22}$ Para compreender mais amplamente o significado dos expurgos na vida social do sistema burocrático, Lefort se utiliza do testemunho de Kravchenko, presente em sua obra Eu escolhi a liberdade (19--), o qual lhe dá um panorama privilegiado sobre as destituições ocorridas até 1953. Além deste testemunho, Lefort
} 
A expulsão de membros do partido, muitos deles executados ou mandados para campos de concentração, é vista por Lefort como "auto-destruição" da classe dirigente, coincidindo com as rivalidades sociais existentes entre suas diferentes facções, com vistas a garantir a estabilidade de um elemento fixo no regime: o chefe supremo Stalin (cf. EL, [1948] 1979c, p. 135). Nesse processo, a colaboração de toda a população se faz notória, pois cada um é, ao mesmo tempo, acusador e vítima. O NKVD - a polícia política da URSS - assume o poder que as próprias vítimas lhe dão, à medida que se acusam e se denunciam reciprocamente para afirmar sua lealdade ao chefe supremo.

Os expurgos massivos de burocratas, técnicos ou de quadros sindicais visavam minar a possibilidade de críticas ao regime, pois elas significavam o mesmo que desintegrar-se da política do Estado, do ideal socialista, constituindo em si mesmas uma ameaça ao sistema. Lefort considera que, na era stalinista, a burocracia se prestava a uma orgia de "criticarias" (criticalleries), dissimulando, portanto, toda crítica verdadeira.

O partido cumpre um papel fundamental na nova fase stalinista do regime, pois instaura uma disciplina de ferro, encarna a unidade incontestada, cimenta os elementos heterogêneos, proclama que interesses particulares estão subordinados aos interesses da burocracia no seu conjunto. Nesse sentido, o Estado não pode ser entendido como expressão de classe, como ocorre na sociedade burguesa, mas sim como consubstancial à sociedade, à classe dominante, de modo que cada um pode dizer plenamente: "o Estado sou eu", sendo também o outro.

O famoso tema do sacrifício das gerações atuais em benefício das gerações futuras apresentado pelo stalinismo travestido de um programa de construção do socialismo recebe seu conteúdo real: o partido exigia o sacrifício dos interesses particulares e dos interesses imediatos das camadas ao interesse geral e histórico da burocracia como classe. (EL, [1956] 1979c, p. 179)

A ditadura stalinista, portanto, exerceu um papel central na cristalização de uma nova classe dominante, a classe dos burocratas. Nesta sociedade burocrática, fundada na dominação de uma classe dirigente sobre a classe proletária, opera-se uma mistificação mais aguda que aquela produzida pelo Estado burguês: enquanto na

cita também os de Anton Ciliga, Au pays du grand mensonge (1938) e de Barmine, Vingt ans au service de l'URSS, (1939), embora considere, na obra de Kravchenko, a existência de mais elementos para pensar o stalinismo, a vida soviética e a vida da camada burocrática. 
sociedade burguesa a diferença entre os proprietários dos meios de produção e a classe trabalhadora - proprietária de sua força de trabalho - é recoberta pela ilusão de que são partes iguais num contrato; na sociedade soviética, cria-se a ideia pela burocracia de que o Estado governa em nome do proletariado e que esta classe, portanto, detém o poder quando, na verdade, encontra-se dele despossuído. (cf. EL, [1956] 1979c, p. 194)

Ao mesmo tempo em que o Estado apela ao proletariado uma participação ativa na produção, o persuade de seu papel dominante na sociedade, lhe recusa toda responsabilidade, toda iniciativa e o mantém nas condições de simples servo do maquinismo aos quais o capitalismo o predestinou desde sua origem. A propaganda ensina, então, cotidianamente o contrário daquilo que está destinada a ensinar. (EL, [1956] 1979c, p. 188)

Aqui está a contradição essencial do regime burocrático, pois a mistificação engendra, em si mesma, as condições para que o proletariado realize sua desmistificação. O regime produz as condições para sua reversão, pesando uma ameaça sobre ele, a qual pôde expressar-se na Revolução Húngara de 1956, por exemplo ${ }^{23}$.

$\mathrm{Na}$ leitura de Lefort, a originalidade do partido não tem sido plenamente compreendida. Os pensadores burgueses mostram-se sensíveis ao significado do empreendimento totalitário encarnado pelo partido, chegam a denunciar a mística social que o domina, mas o rebatem à religião de Estado $^{24}$.

Assombrado por precedentes históricos que dispensam de pensar o presente como tal, compara-se as regras do partido àquela das ordens conquistadoras, sua ideologia àquela do Islam no século VII; se ignora, então, a função essencial que ele exerce na vida social moderna, no mundo do século XX unificado pelo Capital, dependendo no seu desenvolvimento daquele de cada um de seus setores, por sua vez desarticulado pela especialização técnica e rigorosamente centrado sobre a indústria. (EL, [1956] 1979c, p. 189)

O trotskismo compara o partido comunista ao modelo bolchevique, como se fosse uma deformação da ideologia socialista, pela ausência de democracia, por sua conduta contrarrevolucionária, sem perceber que ele assume uma nova função, conforme destacou a análise de Lefort. Para ele, o partido é a instituição a partir da qual

\footnotetext{
${ }^{23}$ Podemos identificar, portanto, que Lefort está atento a novas formas de luta por parte dos trabalhadores no regime totalitário. Em grande medida, esta percepção relativa à Hungria e não compartilhada por intelectuais da esquerda comunista levará Lefort a novos caminhos de reflexão após sua saída do grupo Socialismo ou Barbárie. Como veremos, este acontecimento, bem como Maio de 1968, são significativos no sentido de incitar um novo percurso analítico.

${ }^{24}$ Esta leitura Lefort a relaciona ao ponto de vista sociológico de Monnerot, em seu livro Sociologie du communisme, de 1949.
} 
se opera a sociedade total, é por meio dele que o totalitarismo é veiculado. O partido encarnou a ocasião propícia que lhe possibilitou o stalinismo, de modo que temos, então, o "totalitarismo stalinista", o qual se afirma quando o aparelho político edificado pela revolução silencia as antigas camadas dominantes e se franqueia de todo controle do proletariado. Este aparelho político, por sua vez, passa a ser diretamente subordinado ao aparelho de produção. Como afirma Lefort, o partido totalitário é aquele que

(...) concentra entre suas mãos todos os poderes, se identifica com o Estado e, enquanto Estado, subordina rigorosamente todas as outras instituições, escapa a todo controle social, quando, ao mesmo tempo, no interior do partido, a direção se libera de todas as oposições e faz prevalecer uma autoridade incontestada. (EL, [1956] 1979c, p. 170)

Graças ao partido, o Estado torna-se imanente à sociedade, ou seja, é através dele que a sociedade modifica-se em Estado e vice-versa, de modo que a divisão do trabalho que operava um isolamento entre os indivíduos é, em um sentido, ultrapassada pelo partido que coloca todos ligados, lado a lado, na sociedade total. O partido é o simulacro desta socialização, invade todos os domínios do social, proclamando, difundindo, impondo normas ideológicas de conduta social. Os profissionais do partido atuam, então, fiscalizando, monitorando, cronometrando as condutas de diversos trabalhadores, atribuindo a suas atividades um coeficiente ideológico. Dessa maneira, o escritor, o diretor, o técnico, o biólogo, cada um deles encontra no funcionário político do partido o seu "duplo ideológico" (EL, [1956] 1979c, p. 193), visto que ele estipulará um modo específico de gerir a fábrica, de trabalhar na produção, de fazer filosofia, etc. Por meio do partido, portanto, opera-se em cada domínio a intrusão do político, ao mesmo tempo em que se reengendra a separação da política, destinada aos profissionais do partido $^{25}$. Cabe ao partido, por sua vez, proclamar, difundir e impor normas ideológicas.

Tudo se passa como se a vida social fosse inteiramente dominada por uma fantástica cronometragem cujas normas seriam elaboradas pelas agências mais secretas de estudos.

A atividade do partido reengendra assim uma separação da função política, ainda que se queira aboli-la e, em um sentido, ela a acusa. É, em efeito, em cada domínio concreto da produção, tão particular que seja, que se faz sentir a intrusão do político. (EL, [1956] 1979c, p. 193)

\footnotetext{
${ }^{25}$ Lefort usa o termo "político" para dar a entender que tudo se torna político no totalitarismo, que sua intrusão se dá em todos os domínios do social: no plano estético, jurídico, religioso etc.
} 
O totalitarismo, portanto, não é um regime político de caráter ditatorial, sendo uma forma de sociedade no seio da qual todas as atividades são religadas umas às outras, ou seja, tomadas como modalidades de um universo único. Nesse sentido, ele é uma negação da sociedade burguesa, calcada na constituição de diversos domínios no plano da vida social, a saber, o econômico, o político, o religioso, o estético, o jurídico, o ideológico.

Com relação à atuação militante, no período stalinista, Lefort aponta que fatos como as desigualdades sociais, as condições de trabalho e a repressão policial não produziam inquietações junto a eles. Estes traços assumidos pelo regime eram sempre justificados como decorrentes do isolamento alcançado pela URSS, sempre ameaçada pelo imperialismo norte-americano. Devemos salientar um aspecto primordial neste comportamento: o fato de que a atividade militante era regrada pela direção do partido, por "regras de ouro" (EL, [1956] 1979c, p. 161), o que contribuía para criar um sistema de pensamento mecanicamente orquestrado, segundo o qual os acontecimentos não eram apreendidos por si mesmos - livremente interpretados -, mas sempre reenviados à política de Stalin e, portanto, interpretados e justificados em função das condições objetivas em que ela se encontrava. (ibid., p. 161)

Em tal sistema de pensamento, não havia tomada de posição possível sobre os acontecimentos, a causa se encontrava reenviada, mais e mais, à política de Stalin e aquele se justifica, por sua vez, pelas condições objetivas às quais precisava fazer frente e que tinha somente o poder de apreciar em sua complexidade. Não havia, então, outra possibilidade (senão tudo contestar) que a de regrar sua atividade sobre aquela da direção: militante, era-se stalinista dos pés à cabeça, sem alguma outra referência possível que aquela fornecida pelo partido. Estava-se de uma vez por todas munido de um sistema de reflexos permitindo agir em toda situação, qualquer que ela fosse, que se tratasse do pacto atlântico, da tática sindical, da biologia, da literatura ou da psicanálise. (EL, [1956] 1979c, p. 162)

O afrontamento da "mitologia stalinista", no plano da reforma preconizada pelo XX Congresso do Partido Comunista, é considerado por Lefort como a última mudança de direção (tournant) ocorrida na política russa, a qual se mostra diferente das que ocorreram anteriormente ${ }^{26}$. Neste último momento, a nova direção procurou recusar

\footnotetext{
${ }^{26}$ Quanto a esse "anteriormente", Lefort se refere ao trabalho efetuado pela ditadura stalinista no sentido de criar barreiras a toda ação capaz de colocar em perigo a coesão do regime. Trata-se dos expurgos internos e da política internacional estabelecida pelo Partido Comunista, regrando mecanicamente os partidos comunistas presentes em outros países, como é o caso da França, onde as reviravoltas abruptas da política do PCF refletem as medidas impostas pelo partido-mãe na URSS. Neste aspecto, Lefort cita a guerra contra os socialistas, antes de 1934, a frente popular, a luta contra a burguesia e a guerra
} 
o totalitarismo, afirmando a necessidade de uma direção coletiva, admitindo publicamente que a política da URSS pode ser contestada, fazendo do seu passado um objeto de interrogação. Dessa forma, tais mudanças adquirem uma importância salutar para Lefort, visto que têm o efeito de integrar o presente, o passado e o futuro desta forma de sociedade.

As medidas preconizadas por Khrushchov e Souslov visam ultrapassar certas contradições do passado, na tentativa de inventar certos artifícios destinados a assegurar um melhor funcionamento do regime, particularmente da burocracia, devido aos conflitos e à vulnerabilidade que vinha apresentando. Eles consideram necessário rever o papel do Estado, do partido e da planificação ${ }^{27}$, tendo em vista sempre a culpabilidade de Stalin. Como observa Lefort, todas as medidas promulgadas, não têm qualquer efeito sobre o caráter totalitário do regime, ainda que visem à participação ativa, os seus encaminhamentos levam à subordinação rigorosa de todos os membros da sociedade ao aparelho de Estado. Nesse sentido, cria-se uma nova linguagem burocrática destinada a dissimular os traços burocráticos do regime. As medidas anunciadas no XX Congresso visam suscitar uma nova adesão ao regime, o apelo à cooperação das massas pelo uso de artifícios que permitem modificar os termos dos problemas afrontados, de modo a assegurar a vida e o desenvolvimento do sistema, mascarando suas incompatibilidades e provocando uma nova idealização do regime pela participação no partido. Afirma-se, então, uma liberdade para as massas que, na verdade, é forjada pelos dominantes, o mito renovado da revolução, retomando-se a imagem de Lênin, investindo-se nele um novo poder: ele é considerado o símbolo da democracia revolucionária.

\footnotetext{
imperialista, calcada sob um nacionalismo desenfreado. Tais ações refletem as relações entre o partido comunista nacional e as burguesias locais, as quais eram direcionadas pela estratégia da URSS no mundo.

${ }^{27}$ Com relação ao Estado, a centralização de todas as responsabilidades nas mãos da burocracia de Moscou contribuiu para a existência de uma hostilidade permanente das burocracias locais, tendo o efeito de entravar a planificação que não dava conta das condições específicas de cada república. Assim, propõe-se como medida a ser tomada a descentralização, sem que houvesse uma alteração radical no aparelho central, responsável por tudo decidir. Às autoridades locais, garantiu-se uma certa liberdade na aplicação das diretrizes. Lefort considera que tal descentralização, no entanto, apenas contribuiu para reforçar o burocratismo das direções locais, de modo que não se pode imputar à centralização o desenvolvimento da burocracia, mas sim a ela própria. Quanto ao partido, Khrushchov e Souslov destacam dois traços do partido comunista que precisavam ser revistos: o fato de encontrar-se separado da vida produtiva, não respondendo mais aos problemas colocados pela vida social; e de comportar-se como um grupo particular cuja atividade era puramente formal, visando justificar sua própria existência. Tal análise é próxima daquela de Lefort, a grande diferença está, no entanto, no fato de que estes traços podem ser alterados, constituindo-se apenas como faltas existentes na organização, de modo que o partido era mau e tornar-se-á bom. Para Lefort, o partido sempre conterá aqueles traços, ainda que seja reformado, pois continuará veiculando a regra que interessa à burocracia como classe. No que diz respeito à planificação, esta contém um problema mais profundo que a reforma não pode resolver: o burocratismo.
} 
Sua legenda deve cristalizar a ação coletiva, suscitar uma nova adesão à tarefa comum, promover um militantismo entusiasta análogo àquele que no passado permitiu mover montanhas. (EL, [1956] 1979c, p. 233, grifo nosso)

Em suas conclusões, Lefort considera que o regime instaurado na URSS não pode ser interpretado nem como puramente capitalista, nem como socialista. Estas duas interpretações sobre a URSS sofrem, no primeiro caso, de um artificialismo e, no segundo, de uma mistificação que, na sua ótica, se reencontram num terreno comum marcado pela "fidelidade literal ao marxismo" (EL, [1948] 1979c, p. 136). Neste círculo estreito de reflexão, em que todo e qualquer regime de exploração deve se alinhar ao capitalismo, Lefort já se encontra numa situação pouco confortável, visto que refuta toda a significação socialista do regime, além de afirmar que o regime soviético é, na verdade, um "capitalismo burocrático" (EL, [1956] 1979c, p. 231) pelo fato de não ter eliminado certos vícios inerentes ao sistema capitalista burguês, reintroduzindo outros vícios que testemunham a contradição permanente da sociedade de exploração. Nesse sentido, afirma que o totalitarismo não constitui um acidente na História, pois ele participa da mesma lógica inerente ao capitalismo, constituindo, inclusive, sua forma mais acabada (cf. EL, [1956] 1979c, p. 231).

Por exemplo, a planificação permitiu suprimir um certo tipo de anarquia na produção e a concorrência cega dos interesses privados, mas ela reengendrou um novo modo de rivalidade entre os burocratas, uma inércia dos quadros dirigentes; ela se reduziu a uma coordenação superficial dos ramos de atividade, a uma determinação global do nível da produção, ela se revelou incapaz de medir os esforços da coletividade às custas do trabalho humano real e interditou, consequentemente, de controlar seu funcionamento concreto. Ela propõe um modelo de integração da produção e de participação social desconhecidas em outras sociedades, mas ela está condenada a contradizê-lo para manter a dominação do Capital sobre o Trabalho. (EL, [1956] 1979c, p. 231-232)

No que se refere à ideologia, Lefort afirma que a ideologia totalitária em relação à burguesa, adquiriu uma nova eficácia, pois transforma o indivíduo em ser social, de modo a engolfá-lo em imperativos ditados pela direção burocrática estendidos a todos os domínios de atividade em que ele se encontrar, religando-o a tempos históricos.

[...] a ideologia totalitária possui uma eficácia nova; ela torna o indivíduo sensível, em cada domínio de atividade, aos imperativos da sociedade inteira e de seu futuro histórico, mas ela o priva, ao mesmo tempo, de toda possibilidade de adesão real a estes imperativos ao impor por constrangimento, a norma do aparelho dominante. Em 
relação às ideologias burguesas, ela é, em certo sentido, progressiva, pois visa ao trabalhador enquanto ser social e não, como no quadro da indústria americana enquanto indivíduo separado de outros. Mas, ao fazer isso, ela desenvolve, ao reconhecê-lo, uma necessidade social que se choca, mais fortemente que em outro quadro, às necessidades do explorador. (EL, [1956] 1979c, p. 232, grifos do autor)

Para Lefort, o período stalinista não constitui apenas uma etapa no desenvolvimento histórico do regime socialista na URSS, isto é, uma situação particular alcançada pelas mãos de Stalin, algo como um fenômeno stalinista, conforme explicita Lefort (ID, [1977] 1983a, p. 172). O que buscou enfrentar criticamente é o fato de que traços como os privilégios de uma camada dirigente, a amplitude da diferença de salários, o esmagamento das oposições políticas e a utilização do terror como meio de governo serem vistos como traços acidentais presentes na URSS. Desse modo, no plano da esquerda, estes traços eram considerados como uma "eventualidade teoricamente possível” (EL, [1948] 1979c, p. 131), um “período transitório", a "consequência de uma má gestão" (ibid., p. 129), de tal forma que a representação do socialismo não era colocada em questão. De acordo com ele, as justificações eram da seguinte ordem:

Ou como a marca de uma sociedade que, pelo fato de ter queimado a etapa da revolução burguesa e por lhe faltar uma tradição democrática, demorava para se libertar da herança do despotismo semi-asiático; ou como uma conseqüência das relações de força internacionais, a URSS tendo sido levada, em virtude do cerco dos países capitalistas, a operar escolhas dramáticas, tanto no domínio econômico quanto político, para defender as conquistas de Outubro e assegurar sua segurança. Mais uma vez, os traços de opressão e de exploração na URSS ou, em geral, no Leste, ainda que reconhecidos, não punham em questão a representação do socialismo, cujo progresso era considerado entravado por circunstâncias históricas. (ID, [1977] 1983a, p. 172)

Tais argumentos, conforme explicitaremos mais adiante no momento em que discutirmos a reflexão de Lefort sobre a ideologia, serão retomados nos anos 1970 pela esquerda comunista. Ela evita elogiar a URSS, como se fazia nos anos anteriores, e realiza a crítica de seus "defeitos", com o intuito de reinventar o socialismo, pela propagação de que ele ainda está por ser reinventado. Para Lefort, no entanto, o sonho da esquerda, calcada no ideário da revolução deságua em uma "boa burocracia, eficaz, flexível, e que daria um pequeno lugar a uma autogestão vigiada pelos entendidos e pela polícia” (ibid., p. 175). 


\subsection{A degradação ideológica do marxismo}

As propostas de reforma estabelecidas na URSS por Kruschev foram bem vistas pelos militantes do partido comunista, segundo Lefort, tendo sido consideradas como um retorno aos princípios originais do comunismo, extirpando-se, por sua vez, os traços stalinistas adquiridos pelo regime.

Tais propostas fazem parte de um processo que Lefort denomina "degradação ideológica do marxismo", pelo fato de que visam produzir boas reformas ao invés de uma prática efetivamente revolucionária, revelando, dessa forma, um depreciamento do marxismo revolucionário. As medidas tomadas na URSS visam produzir um "remendo" na estrutura do regime, ou seja, eliminar as contradições surgidas, ao invés de se voltarem para uma mudança radical no plano das relações sociais estabelecidas, de modo que os militantes comunistas falam em "boa planificação", em "boa burocracia", propagam a necessária inexistência de um partido único e na constituição de órgãos representativos mais eficazes da classe trabalhadora, em defesa, portanto, de uma fórmula capaz de resolver todos os problemas. Nesta ideia de uma sociedade progressiva (EL, [1963a] 1979c, p. 312), eles propagam um discurso em que as contradições presentes no regime soviético mostram-se acidentais, passíveis, portanto, de serem suprimidas via reformas.

Deste ponto de vista, há, aos meus olhos, um depreciamento do marxismo. Aquele que tende a se transformar em ideologia. Ele não é mais uma teoria da realidade para aqueles que a reclamam; é, antes, o complemento mítico de um "progressismo" ou de um reformismo que não ousa dizer seu verdadeiro nome. (EL, [1963a] 1979c, p. 313)

Lefort identifica três tipos de reformismo que vêm substituir o marxismo revolucionário: o reformismo cientificista ou positivista, o reformismo moralizante e o reformismo revolucionarista. No primeiro, o sistema social existente pode ser melhorado por meio de modos de ajustamento. Aqui, Lefort critica o uso feito pela Sociologia acerca dos conceitos de "adaptação social" e "ajustamento social", com vistas ao entendimento da prática trabalhadora.

O segundo constitui aquele de uma tendência sociológica norte-americana, considerada por Lefort como minoritária, cuja figura emblemática é Wright Mills e que se expressou também na França, a qual ataca violentamente a sociedade presente, mas 
sem apresentar uma concepção de conjunto da realidade social. Nessa leitura, as soluções que procura dar recorrem a um ideal de justiça, razão e progresso, fundando-se em julgamentos de valor, estabelecendo, portanto, uma linguagem moralista.

Eles denunciam a injustiça do sistema atual, falam do progresso, da liberdade, da necessidade de destruir o capitalismo para arrancar a humanidade da barbárie. Mas, esta linguagem tornou-se extremamente vaga. Coloca-se o acento sobre a exigência de uma reviravolta revolucionária, mas preserva-se de evocar a imagem de uma sociedade sem classes, em que os produtores gerariam, eles mesmos, a produção. (EL, [1963a] 1979c, p. 311)

A terceira, relativa ao reformismo revolucionarista, concebe a necessidade de uma mudança na estrutura econômica, propõe a eliminação das contradições do sistema capitalista, chega a afirmar que a luta pelas armas pode ser necessária, mas, no fundo, não crê efetivamente em uma transformação radical da sociedade, a qual daria origem a uma sociedade sem classes.

Lefort considera que estas três interpretações são representativas de um depreciamento do marxismo, visto que não exprimiriam mais uma concepção total do mundo nos termos colocados por Marx ${ }^{28}$, mas uma nova linguagem, empregada por reformistas e conservadores, a qual contribui para dissimular, mascarar as relações concretas instituídas entre os homens e as organizações. Este depreciamento significa, portanto, que o marxismo transformara-se em ideologia, não sendo mais uma teoria da realidade, mas um conjunto de ideias que, no lugar de refletir sobre questões colocadas pela realidade, ela mesma, realiza determinadas interpretações que seriam, na verdade, um complemento mítico daquelas visões reformistas.

Nesse sentido, instaura-se, sob o ponto de vista de Lefort, um debate imaginário, visto que, ao invés de haver uma discussão sobre uma mudança radical das relações sociais instauradas, tanto na sociedade capitalista como na socialista, propagase a imaginação de uma sociedade progressiva, reformada pela eliminação de suas

\footnotetext{
${ }^{28}$ Segundo Lefort, a teoria de Marx constitui-se como um sistema de mundo, na medida em que é uma teoria da política, uma teoria do funcionamento da sociedade, uma política que provocou o surgimento do socialismo. Trata-se, portanto, de uma teoria da realidade e de uma política que tem como expressão o proletariado. Quanto à ciência social, esta, seguindo Marx, não poderia constituir um momento independente no processo histórico, devendo coincidir com o ponto de vista do proletariado, visto que este detém o ponto de vista da totalidade, tal como identificado por Lukács. Nesse sentido, a política marxista que se encarna numa vanguarda ou numa organização deve constituir-se como a expressão da classe em luta por sua emancipação. Tendo em vista tais considerações, Lefort avalia no início dos anos 1960, que a maior parte dos marxistas, o que o inclui, não tem mais esta visão de mundo.
} 
contradições internas, enfatizando-se os méritos da planificação, da organização racional do trabalho. Assim, não há um debate focado na questão do distanciamento instaurado entre uma massa condenada a tarefas de produção com relação à qual está privada de qualquer decisão, e, de outra parte, uma camada de dirigentes que, no caso da URSS, segundo Lefort, não têm um papel muito diferente daquele que ocupa, nas sociedades ocidentais, a camada de dirigentes capitalistas.

Ao identificar o que tais correntes vinham produzindo em termos de reflexão teórica acerca do caráter das lutas sociais, Lefort anuncia um novo caminho de análise. Primeiramente, ele enfatiza a necessidade de "visar à sociedade tal qual ela é" (EL, [1963a] 1979c, p. 320), afirmando que não se deve procurar ressuscitar um ideal novo de comunidade, como aquele de um socialismo futuro ou, ainda, calcar-se no mito do bom passado, como permanecer no "mito da era de ouro" da democracia norteamericana. Ao invés de produzir-se a negação da sociedade advinda, Lefort considera importante acolher a modernidade e não se desviar, nem mesmo dela se evadir ao recorrer-se a tais mitos. Para tanto, considera fundamental a consciência de que se fala "no interior da sociedade presente", fruto do que advém historicamente, de modo que, para ele, deve-se aceitar ver no presente outra coisa que o mal, decifrando-o, apreendendo-o conforme o sentido adquirido pelos empreendimentos estabelecidos, segundo as condições em que advêm seus pensamentos e suas ações, tornando-se sensível para o fato da exploração, realizando sua denúncia. Ao mesmo tempo, Lefort propõe que se revele toda forma de contestação da ordem estabelecida, esclarecendo as formas de resistência empregadas espontaneamente para fazer frente àqueles que detêm o poder e se obstinam a perpetuá-lo ou, ainda, as ações que procuram alterar as regras burocráticas responsáveis por sufocar aquelas iniciativas, privando os indivíduos de estabelecerem uma comunicação e de deterem informações sobre as instituições nas quais estão situados.

Lefort, portanto, visa colocar-se criticamente às ideologias de conservadores e reformistas, preconizadas por militantes e presentes no programa e nas ações do Partido Comunista, bem como por teóricos oriundos da Sociologia norte-americana. Ele assume como tarefa "desvendar" toda tentativa de dissimulação por eles operada com relação aos "verdadeiros antagonismos" (EL, [1963a] 1979c, p. 322), a fim de "esclarecer" as relações estabelecidas entre os homens e as regras de funcionamento das organizações. 
Esta crítica é revolucionária no sentido de que ela desvela os verdadeiros antagonismos que conservadores e reformistas empregam sempre para dissimular, que ela traduz sempre nos termos das relações concretas instituídas entre os homens e as regras de funcionamento das organizações que os mascaram e, da mesma forma, esclarece e atiça a luta social. (EL, [1963a] 1979c, p. 322)

Em contraposição àquelas ideologias, busca manter uma atitude realista, ou seja, procurar na realidade, em si mesma, as condições segundo as quais a contestação pode ocorrer. Ele procura, então, todas as ações contestadoras que visem transformar, recriar a realidade em relação às pretensões de regramento da vida social, tal como promovido pela burocracia. Para tanto, afirma não compartilhar do "mito da revolução", isto é, do mito de que uma revolução pudesse abolir de uma vez por todas as causas da alienação na sociedade, se interessando muito mais pelas ações de resistência promovidas pelos homens. Assim, se sua perspectiva é revolucionária é porque

[...] ela é franqueada do mito de que uma revolução poderia, de uma vez, revirar profundamente, de forma satisfatória, a estrutura da sociedade e, como o imaginava Marx, suprimir as causas da alienação. Ela quer ser realista, isto é, buscar na realidade, ela mesma, as condições da contestação das estruturas de exploração - condições que não foram criadas de uma vez por todas no passado, de tal sorte que elas esperariam meio século para serem agarradas por um bom Partido, tal como acreditavam alguns, mas que não deixam de se transformar e de serem recriadas, como nos ensina o fato de que as burocracias, a despeito de sua expansão contínua e de sua pretensão sempre crescente a regrar toda a vida social, se revelam impotentes para dominar as resistências, sufocar as necessidades e os empreendimentos que fazem nascer $o$ desenvolvimento da sociedade moderna, o desenvolvimento da produção, a circulação da informação, a mistura de grupos e de pessoas. (EL, [1963a] 1979c, p. 322)

Como vimos, as críticas de Lefort centram-se na teoria marxista, calcada na sua perspectiva, em um “otimismo revolucionário" (EL, [1970b] 1979c, p. 371), mistificador e mistificado. Ele considera que a permanência no quadro teórico marxista contribuiu para que a esquerda não conseguisse aceitar os horrores praticados na URSS, vendo os traços do totalitarismo como acidentais. Ao mesmo tempo, considera que esta permanência, no círculo marxista, tinha o efeito de impedir a compreensão de novos acontecimentos como a Revolução Húngara em 1956, a qual, na sua visão, consistiu em uma tentativa de derrubada do regime totalitário (ibid., p. 371)

Após sair do grupo Socialismo ou Barbárie, em 1958, Lefort retira-se do círculo marxista, com vistas a explorar e dar prosseguimento a questões nascidas no seu interior, mas incapazes de serem plenamente exploradas em virtude da fidelidade 
exigida em relação ao marxismo. A partir de então, outro movimento de pensamento instaura-se, o qual se orienta muito mais pela atividade teórica do que pela militância política, passando, então, a submeter-se à autoridade de seu leitor. Não deixará de abordar a obra de Marx, mas o fará com o objetivo de liberá-la da vulgata determinista característica do meio comunista, procurando preservá-la do "mito da teoria marxista" (FH, [1978c] 1979b, p. 14).

A seguir, discutiremos a importância dos estudos antropológicos realizados por Lefort, ainda nos anos 1950, e que serão articulados a novos questionamentos.

\section{Os estudos antropológicos}

Nos anos 1950 e 1951, uma parte dos estudos de Lefort é destinada a leituras de trabalhos etnológicos, período em que passa boa parte de suas horas diárias no Museu do Homem, realizando leituras das obras de Marcel Mauss, Claude Lévi-Strauss, Evans-Pritchard, além das de Abram Kardiner, Radcliffe-Brown, Malinowski, Margaret Mead e Gregory Bateson, autores que cita mais frequentemente em seus artigos. Estes estudos foram publicados em revistas como Les Temps Modernes e Cahiers Internationaux de Sociologie e reunidos, posteriormente, no livro As formas da História: ensaios de antropologia política, publicado pela primeira vez na França em 1978, compondo os cinco primeiros capítulos desta obra ${ }^{29}$. Reinseridos em nova disposição esboçada pelo autor em seu prefácio, estes artigos compõem um novo panorama de análise, uma vez que neles já encontramos o desenho de uma problemática relativa à História que nos levam ao tema da ideologia. Referimo-nos, particularmente, às discussões que Lefort realiza a partir de certos estudos etnológicos sobre os princípios de conservação, de repetição e de transformação que estão presentes em determinadas sociedades e que definem diferentes modos de apreensão temporal da vida social. Sua atenção concentra-se em certas sociedades - primitivas - que se agenciam contra a História, elaborando as condições de sua própria estagnação, calcadas na tradição e nos mitos. Como poderemos observar, no caso das sociedades históricas -

\footnotetext{
${ }^{29}$ Não por acaso, este livro se abre em torno de discussões relativas a diferentes formas de História, pelo questionamento acerca do significado da mudança em diferentes sociedades, contendo lógicas temporais distintas, as quais se fazem a partir dos estudos etnológicos, e se fecha com a questão da ideologia. Neste movimento, Lefort articula as amarras de uma argumentação tecida durante vinte anos, em torno da ideia de indeterminação do sentido que se dá em relação à História e a uma obra de pensamento, refletidos frente ao problema da ideologia.
} 
ocidentais -, tal agenciamento também ocorre, mas de modo a resistir à mudança, ao acontecimento, a denegar a História, sendo a ideologia o discurso privilegiado para tal operação, visto que ela oculta todos os sinais que provocam rupturas com práticas e representações instituídas.

Entusiasmado com a literatura etnológica, Lefort afirma que nela encontrou novos elementos de reflexão que o permitiram realizar uma crítica à Filosofia da História, em relação aos estudos de Hegel, Marx e também aos escritos de Husserl. O ponto de partida é a ideia de que as sociedades ditas primitivas não teriam História, como na afirmativa de Hegel de que a Índia e a China não seriam históricas, visto que elas não têm consciência de si, sendo condenadas a um imobilismo. Quanto a Husserl, Lefort afirma que este pensador também rejeitou ou colocou para fora da verdadeira história toda a humanidade não europeia. Com relação a Marx, ele critica a perspectiva que reduz a história à luta de classes, voltando-se exclusivamente para uma lógica marcada por etapas que se sucedem em função das contradições que acompanham os diferentes modos de produção ${ }^{30}$.

Do ponto de vista de Lefort, a filosofia deveria dar conta da sociedade "estagnante" e diferenciar seu modo próprio de devir e considerar, então, que gênero de historicidade ela revela e que relação de parentesco há entre tais sociedades e as sociedades históricas, uma vez que parte da premissa de que toda sociedade contém em si o acontecimento, a transformação cultural e a retomada vivida do passado pelo presente. A grande questão passa a ser, então, esboçada da seguinte forma: "A relação ao acontecimento, a transformação, a retomada do passado têm sempre a mesma significação?" (FH, [1952b] 1979b, p. 46).

Os trabalhos de campo desenvolvidos pela Etnologia poderiam angariar elementos para desenvolver a resposta e favorecer a reflexão sobre diferentes esquemas do devir ou formas de história. Vejamos o caso da sociedade balinesa estudada por Gregory Bateson e retomada por Lefort. Marcada pelo imperativo da estabilidade, nesta sociedade, há formas de evitar o conflito pela limitação do diálogo, o tempo é contado de tal forma a não ser possível referenciar o acontecimento ao quadro de uma diferença entre passado, presente e futuro, ou seja, há uma incapacidade em imaginar um futuro indeterminado, de modo que ele é tão fixo quanto o passado. De um modo geral, o caso

\footnotetext{
${ }^{30}$ Os contornos desta discussão serão apresentados no próximo capítulo.
} 
de Bali é significativo, em razão do modo de resolução de seus conflitos que poderiam abalar sua estabilidade e de sua forma (mise en forme) cultural em que há a inibição do histórico, da natureza de seu futuro não criador que coincide com um estado no qual os homens se encontram mais estritamente situados uns com relação aos outros, definidos por laços de dependência. Tal exemplo nos convida a reler um modo de historicidade e um modo de socialização, a tal ponto que a estagnação não pode ser vista como um fato da natureza, mas da coexistência, estando implicada na maneira segundo a qual os homens se percebem e se relacionam uns com os outros, isto é, numa práxis coletiva.

Há sociedades cuja forma se manteve, indubitavelmente, durante milênios e que, a despeito dos acontecimentos os mais variados de que foram teatro, de sua diferenciação interna, dos progressos técnicos e científicos, ordenam-se em função de uma recusa do histórico. Nós a denominamos "sem história", não para dizer que não conheciam mudanças, mas para pôr em evidência sua tendência a neutralizar os efeitos da mudança. É um modo de organização social - julgávamos - que a temporalidade se imprime. As sociedades "estagnantes" não se situam aquém da era do desenvolvimento histórico: elas elaboram as condições de sua estagnação. (FH, [1978c] 1979b, p. 17)

Tais sociedades, portanto, atestam uma maneira singular de ser no tempo, em que há instituições, representações e mitos responsáveis por desarmar os efeitos dos conflitos, de tudo o que pode ser fonte de mudança no plano das relações sociais. Nesse sentido, elas revelam um gênero específico de historicidade, visto que a sociedade primitiva se fecha para o futuro, não contempla a consciência de se transformar, constituindo-se pela reprodução de suas relações ${ }^{31}$.

Para Lefort, o que define uma sociedade como histórica é o fato de que ela contém o princípio do acontecimento, isto é, dá lugar à experiência de um debate que articula presente, passado e futuro, em que os homens debatem sobre o sentido de seu próprio tempo.

O próprio de uma sociedade "histórica", segundo nos parece, é que ela contém o princípio do acontecimento e tem o poder de convertê-lo em momento de uma

\footnotetext{
${ }^{31}$ Lefort extraiu da literatura etnológica a convicção de que o fenômeno das sociedades ditas primitivas colocava em xeque os princípios da filosofia da História de Hegel e Marx e a que está presente nos últimos escritos de Husserl. Resumidamente, podemos dizer que aquela literatura permitiu a Lefort "abandonar a ideia de uma História em si e para si, na qual as formações sociais estariam encadeadas, como se cada formação social criasse, em seu próprio desenvolvimento, as condições de sua superação. Ele afirma que "A natureza das sociedades primitivas dava testemunho de uma recusa da história, assim como a natureza das sociedades ocidentais modernas dá testemunho de um consentimento à história" (DEP, [1987] 1992a, p. 307).
} 
experiência, de modo que ele figura um elemento de um debate que se processa entre os homens. Deste modo, nela a transformação não é essencialmente a passagem de um estado para outro, mas o encaminhamento deste debate que antecipa sobre o futuro referindo-o ao passado. O que significa ainda dizer que o histórico não reside no acontecimento enquanto tal ou na transformação enquanto tal, mas em um estilo das relações sociais e das condutas em virtude do qual há colocação em jogo do sentido. (FH, [1952b] 1979b, p. 46-47)

A diferença com relação à sociedade de caráter estagnante encontra-se no fato de que nela o acontecimento não desencadeia uma dialética da mudança, não sendo, por sua vez, portador de um sentido, de modo que os homens se ocupam em assimilá-lo, pelos imperativos culturais de adaptação e pelo desejo de conservação que os anima. Nesse sentido, para Lefort, as sociedades primitivas davam o testemunho de uma "recusa da história", enquanto as sociedades ocidentais modernas o de um "consentimento à história", ou seja, aquilo que se denomina "história" não pode se separar de um modo singular de instituição do social (cf. DEP, [1987] 1992a, p. 311)

Neste paralelo, Lefort adquire a compreensão de que as sociedades mantêm modos específicos de se relacionar com o passado, com o presente e com o futuro. A distinção entre sociedades "sem história" e sociedades "históricas", no entanto, não deve impedir uma relação de similaridade importante identificada por Lefort: a ideia de que ambas produzem um agenciamento contra a História.

Por fim, longe de me deter na idéia de uma diferença radical entre "sociedades sem história" e "sociedades históricas", eu punha em relevo uma série de traços no interior das primeiras que não eram estranhos à configuração das segundas e, mesmo nestas, os sinais sempre persistentes de uma resistência à mudança, de uma tendência sempre reiterada a um fechamento nos limites já conquistados. (DEP, [1987] 1992a, p. 306)

Ao procurar refletir sobre os acontecimentos que marcam a sociedade moderna, como é o caso do totalitarismo e da democracia, das lutas sociais, das obras de pensamento, Lefort identifica que há meios utilizados para produzir o mesmo tipo de agenciamento contra a História característico das sociedades primitivas. Fazemos referência aos discursos conservadores, ocupados em desarmar o sentido, buscando assimilar o acontecimento como fonte de mudança, tais como os mitos que discutimos anteriormente, assim como a ideologia, a ser discutida no próximo capítulo. 
O que há por traz destes discursos é um desejo de conservação, pelo fato de existir em todas as sociedades o medo de dissolução do social, ou seja, o perigo latente de que os laços de dependência possam ser desfeitos, o risco de que se rompa o vínculo que une os homens. Tal compreensão Lefort adquire pela leitura dos estudos de Mauss, ao explicitar o significado do Potlatch, um sistema de trocas vivido e pensado pelos homens, descrito anteriormente por M. Davy e Malinowski e por ele pensado como presente em todas as regiões do mundo, em graus diversos. As trocas constituem atos que têm o efeito de colocar os homens frente a frente, pois aquele que dá e o que recebe encontra-se numa inter-relação que os aproxima e os distancia, levando-os a um reconhecimento mútuo e a uma comunicação, na qual o sujeito e o outro podem ver-se numa relação de mútua dependência, sinal de cooperação, mas também como ameaça de morte, estabelecendo-os como adversários. Trata-se da obrigação de dar e de restituir, em que o objeto dado é animado por um poder espiritual, o Dom, que carrega o espírito do doador, criando laços místicos entre os homens no Potlatch.

O essencial é o instante em que eles se colocam face a face, se reconhecem, dão um objeto não apenas para receber, mas para que o outro dê e participe da relação social. Lefort se atém ao fato de que este contrato sempre pode ser rompido, a partir do momento em que haja a recusa em participar do intercâmbio, incitando à guerra privada ou pública. A passagem da festa, ou seja, da comunhão à guerra, revela que rejeitar a comunicação constitui o mesmo que colocar a sociedade em perigo, impedindo o reconhecimento humano e, por sua vez, abrindo passagem para a dissolução do social, do cogito coletivo ${ }^{32}$.

Nesta leitura sobre o significado da troca, Lefort enfatiza que ela não se reduz a seu caráter econômico, contendo uma "pluralidade de significações", o que pode ser designado como fato social total, ou seja, a ideia de que um fato pode ser, ao mesmo tempo econômico, jurídico, moral, religioso, estético. Nesse sentido, Lefort adquire a compreensão de que a separação entre o econômico e o ideológico na realidade não tem sentido, a não ser por conta de uma exigência de conhecimento fundada na teoria de Marx. Nesta leitura, não há uma relação de causa e efeito entre certos fenômenos, mas

\footnotetext{
${ }^{32}$ Mais adiante retomaremos esta ideia, pois Lefort se atém às estratégias criadas na sociedade moderna para eliminar o risco de dissolução do social. Este perigo iminente de rompimento do laço que garante o "Eu" coletivo evidencia-se sempre que há lutas sociais, revoltas, revoluções, tudo o que aponta no sentido de provocar rupturas na ordem estabelecida e que os discursos ideológicos têm o efeito de salvaguardar pelo recurso a referenciais e heróis do passado, por exemplo, pelo ocultamento de tudo o que aponta para o novo, para os possíveis.
} 
uma ligação em que os fenômenos sociais podem alcançar uma plenitude maior que a esboçada nas análises sobre a sociedade moderna em que uma ordem econômica funda todos os outros fenômenos.

Com relação à reflexão sobre a ideologia que discutiremos no próximo capítulo, este estudo de Lefort sobre o fato social total o leva a pensar o significado da dissociabilidade de esferas na sociedade moderna - política, econômica, jurídica, religiosa, estética, etc. - as quais são objeto de uma totalização pela ideologia totalitária e que na democracia, conterão diferentes lógicas ideológicas.

O último ponto que gostaríamos de abordar encontra-se no estudo que Lefort realiza sobre a ideia de alienação, tendo como ponto de partida o estudo etnológico de Evans-Pritchard sobre a sociedade Nuer. No artigo "A alienação como conceito sociológico" (1955 [1979b]), ele provoca um desvio em torno de uma argumentação que poderia pautar-se exclusivamente nos escritos de Marx, para pensar o caso de uma sociedade africana, não industrializada, mas cuja cultura manifesta uma dependência em relação à vaca muito semelhante à que ocorre nas sociedades modernas em relação à máquina. O animal está no centro da vida social: a preocupação com os rebanhos determina os movimentos dos habitantes, além de ser fonte de riqueza, objeto de cuidados, símbolo de prestígio, definindo os laços de parentesco em virtude do pedigree dos animais, bem como tendo por referência animais dados. Enfim, há na sociedade Nuer uma redução de todas as relações sociais de caráter econômico, parental ou místicas a um tipo de relação centrada no gado, revelando um caráter obsessivo, alienante, assim como ocorre na sociedade industrial.

A partir destas últimas observações, não seria exagerado concluir que existe para o Nuer um universo vacal tal como existe para outros um universo maquinal, no sentido preciso de que o homem tenderia a se abolir no primeiro caso diante da vaca, assim como alhures tende a se abolir diante da máquina. (FH, [1955] 1979b, p. 66)

Convém perguntar, então, se haveria na sociedade Nuer uma alienação do homem que faria das vacas a realidade por excelência, despojando-o de sua própria existência, das relações que poderia manter, justamente por haver uma dominação do gado sobre o homem? Poderíamos, então, falar em uma irrealização Nuer? Lefort conclui que isto seria absurdo e, seguindo as análises de Pritchard, considera que não há uma distinção entre imaginário e real na sociedade Nuer a não ser que esta seja feita por 
um observador estrangeiro, como é o caso do etnólogo. Este, por sua vez, abstém-se de fazê-lo por entender que, para atingir sua compreensão, ele deve penetrar nela e conceder que "os elementos aparentemente de ordem imaginária são os mais reais" (FH, [1955] 1979b, p. 69).

É somente quando nos colocamos fora da sociedade nuer, como observador estrangeiro, Evans-Pritchard, que podemos considerar o interesse deles pelo gado como uma obsessão e distinguir o imaginário do real. Mesmo este juízo é impossível de fundar e todo etnógrafo abster-se-ia de desenvolvê-lo. Pois, se quisermos compreender a sociedade nuer em termos absolutos, é preciso penetrar nela e conceder, então, que os elementos aparentemente de ordem imaginária são os mais reais, no sentido de que são eles que fornecem aos homens um quadro de referência permanente. A posição de estrangeiro dá acesso à descrição, já que a seus olhos nada é evidente, mas impede a objetivação, pois as significações só se conquistam circunscrevendo-se um universo humano estritamente singular, no seio do qual se fundam como realidade. O que é o mesmo que dizer que nem do interior, nem do exterior é a alienação nuer denunciável. (FH, [1955] 1979b, p. 69)

Lefort, então, enfatiza que o caso Nuer revela a importância de uma análise que se situe no interior da sociedade para que a questão da alienação possa ser compreendida. Assim, a alienação não decorre de uma projeção da relação social em um objeto - mercadoria ou dinheiro na sociedade ocidental ou da vaca na sociedade Nuer -, mas sim das condições em que estão arranjadas as relações sociais de trabalho, pela autonomização de cada um dos setores de atividade, o que faz com que cada categoria social faça a experiência de uma realidade e de uma irrealidade justamente porque não há esta distinção no plano das relações sociais.

O enraizamento na sociedade graças a uma atividade fixa é inevitável, mas se tornou loucura, isto é, converteu-se em irrealidade, ou ainda, faz surgir pela primeira vez o problema da realidade enquanto tal, no terreno da sociedade. (FH, [1955] 1979b, p. 74-75)

Este problema da dissociação constante entre realidade e irrealidade que se dá nas sociedades modernas é fundamental para que possamos compreender o movimento de pensamento de Lefort em torno da ideologia. Neste ponto, Lefort visava reatar certos elementos presentes no pensamento de Marx, em contraposição a outros que vinham sendo retirados da obra deste autor, o que contribuía para a "abstração", na medida em que se fica apenas com o significado da projeção da relação social, quando, na verdade, deve-se reconhecer que cada categoria social, em função do processo de divisão dos setores de atividade, encontra-se em condições de fazer a experiência da realidade e da 
irrealidade ao mesmo tempo. Esta relação, por sua vez, não pode ser subjugada, mas considerada como inerente a uma sociedade da alienação, de uma sociedade que faz a experiência do real, do irreal e da questão da verdade.

Neste capítulo, vimos que os primeiros estudos de Lefort, ainda no grupo Socialismo ou Barbárie, já continham fundamentos críticos a respeito da perspectiva marxista e sobre o modo de interpretação do regime Totalitário. Nesta discussão, ele desenvolve suas reflexões contra o que considera mistificações - o mito do partido, o mito do bom regime, o mito da revolução. Essa crítica aos mitos tem importância fundamental em nosso entendimento da ideologia, pois embora o mito não contenha o mesmo sentido atribuído pelo autor à ideologia, como veremos a seguir, ele "contribui à sua formação" (LTO, 1986c, p. 764), constituindo uma peça privilegiada neste processo de elaboração de um discurso ideológico. Isso porque, no âmbito da sociedade histórica que operou uma quebra com a ordem transcendente, o mito cria um espaço primitivo no qual a história, o acontecimento se apresentam como algo antes da própria História, justamente porque cria uma figuração dela mesma que, na verdade, é infigurável, permanece como impensado, o "ainda-não". O mito, então, antecipa e busca impedir o surgimento de novas questões, aquilo que ainda não tem forma, nem nome e que anuncia possíveis na sociedade histórica.

Toda esta crítica às mistificações contém internamente, em gestação, o problema a ser exposto nos anos 1970, sobre a ideologia, pois os mitos são narrativas simbólicas sobre a realidade, contêm crenças que não podem ser contraditas, detendo uma verdade sobre aquilo que é justo e o que não é, requerendo um culto e um rito a certas divindidades, resistindo ao tempo. Dessa maneira, no modo como emprega Lefort, os mitos contribuem para a formação de uma ideologia e mantêm um parentesco com ela que também afirma uma verdade e cria um fundamento para o real. A principal distinção a fazer, no entanto, é que o mito não rege o imaginário da sociedade histórica, embora isso não queira dizer que ele tenha desaparecido, uma vez estabelecida a ideologia no seu lugar. Esta, por sua vez, está sujeita à contradição, isto é, ela não se mantém petrificada como o mito, mas permanece como um "debate ininterrupto, movediço, das ideologias" (PP, [1981b] 1991, p.265).

Assim, Lefort praticamente não fala de ideologia até os anos 1970, mas é possível percebê-la como algo presente, a comandar seus movimentos de pensamento, o 
que significa que ela está no seu horizonte, mas ainda não é objeto explícito de sua reflexão. Em seus primeiros estudos, vimos que Lefort encontra-se em um círculo estreito de reflexão, marcado pelo pensamento marxista, de modo que suas análises recorrem a referenciais etnológicos que abarcavam a explicação mitológica para a compreensão de determinadas crenças e cristalizações que, na sociedade primitiva, não apareciam como tais. Dessa maneira, ele recorre a outros referenciais teóricos, fora do círculo no qual se encontrava e, com isto, procura deter o mesmo olhar que o etnólogo dirige para a sociedade selvagem, mas com relação às visões engendradas em sua época sobre a sociedade totalitária e sobre sua própria condição de militante.

A todo o momento, como vimos, Lefort está em busca da realidade, da experiência vivida pelo proletariado e não aquela preconizada pelos dirigentes partidários, dos testemunhos sobre os campos de trabalho e dos horrores praticados na URSS, do significado socialista do regime que, no fundo, lhe parecia manter laços estreitos com o sistema capitalista com o qual julgava romper, na medida em que havia exploração do trabalho e a ascensão de uma nova classe - a classe dos burocratas. Nesse sentido, portanto, o seu movimento de pensamento, nestes primeiros estudos, pauta-se pela crítica às representações de sua época, com vistas a colocar em questão tudo o que nutria "o mito de um sistema perfeitamente coerente" na URSS (EL, [1956] 1979c, p. 156).

Os estudos realizados sobre os trabalhos etnológicos, como vimos, adquiriram grande importância na abertura de novos referenciais teóricos para a interrogação sobre o jogo entre real e irreal na sociedade primitiva e na sociedade histórica, pois considera que a idealização está inscrita na realidade social, constitui uma tentativa de apreensão do universal, não devendo ser vista, portanto, como simples erro ou evasão do real. A idealização, para utilizar expressões posteriores de Lefort, é uma resposta, cumpre uma virtualidade inscrita no real: a tentativa de apreensão do universal por conta da particularização do social. A noção de fato social total e de eficácia simbólica, por sua vez, tomará a forma de uma reflexão sobre a imbricação de esferas - da lei, do poder, do econômico, do saber, do estético -, de modo que Lefort chega a compreender que não são apenas as condições materiais de existência que devem ser objeto de reflexão, mas também a interligação entre os fatores culturais, econômicos, políticos, estéticos, entre outros, no entendimento de uma certa forma de sociedade. Todas estas noções, portanto, 
objeto de sua reflexão, nos anos 1950, estão no cerne de seu entendimento sobre a ideologia. 


\section{CAPÍTULO 2 - O nascimento da ideologia}

\section{Introdução}

No momento em que a ideologia torna-se um tema explícito de reflexão por parte de Lefort, na década de 1970, o leitor se depara com três artigos: "O nascimento da ideologia e do Humanismo" ([1973] 1979b), "Esboço de uma gênese da ideologia nas sociedades modernas" ([1974] 1979b) e "Uma ideologia de Granito" ([1976c] $1976 b)^{33}$. O tema parece se desenrolar apenas neste pequeno conjunto de ensaios que não se distanciam no tempo e, de certa maneira, dão o tom de uma reflexão que se abre e logo se fecha ali mesmo. Concordamos em parte com esta percepção, contudo, na vasta produção intelectual de Lefort, em seus sessenta anos de escritos (1945-2005), estes três estudos são centrais no que tange ao tema em questão e há referências breves e circunscritas em diversos outros ensaios posteriores que tratam da democracia e do totalitarismo ${ }^{34}$. Acreditamos que somos levados a uma ilusão de ótica, pois temos a impressão de que a ideologia constitui um tema marginal, localizado, datado e que esteve frente aos olhos do autor em certa ocasião para depois permanecer como lembrança ou referência a compor outro esboço, no qual sua atenção estaria voltada para aqueles outros dois temas centrais de sua obra.

Esta percepção primeira não deve ser ignorada, nem mesmo ser considerada como um equívoco, pois há uma intenção implícita nesta fala curta e devemos compreender também que não é por acaso que a ideologia só aparece por um breve momento, em certa ocasião e em certo lugar da obra. Perguntamo-nos, então, o que teria levado o autor a refletir sobre ela, por que o fizera apenas nos anos 1970 em poucos

\footnotetext{
${ }^{33}$ Os dois primeiros artigos foram republicados no livro As formas da história: ensaios de Antropologia política (1979b) e o terceiro constitui o quinto capítulo do livro Un homme en trop. Réflexions sur "L'Archipel du Goulag" (1976b). Além destes artigos mencionados, já se pode encontrar uma discussão sobre a ideologia em sua tese doutoral Le travail de l'oeuvre Machiavel (1986c), no capítulo que se intitula "L'oeuvre, l'idéologie et l'interprétation" que discutiremos mais a frente.

${ }^{34}$ Podemos indicar alguns artigos, em que Lefort faz menção explícita à ideologia, quando procura refletir sobre a democracia e o totalitarismo, tais como "Direitos do homem e política" ([1980b] 1983a), em que questiona a importância da luta pelos direitos humanos nas sociedades democráticas como ação política em ruptura com a ideologia, "A imagem do corpo e o totalitarismo" ([1979a] 1983a), "Reculer les frontières du possible"([1981c] 2007), em que fala da ideologia totalitária, "Uma outra revolução"([1977] 1983a), a contrarrevolução húngara de 1956 e o perigo do saber dissolvido em ideologia pelo socialismo, “Démocratie et avènement d'um 'lieu vide'([1982a] 2007), “A questão da democracia"([1983b] 1991), "La liberté à l'ère du relativisme”([1989] 2007) sobre a ideologia na democracia, além de inúmeros outros artigos e entrevistas em que o autor se refere à ideologia.
} 
artigos e como ele a expressaria em seu pensamento, na sua perspectiva? Com essas indagações, iniciamos nossas reflexões acerca do tema propriamente dito, pois no caminho que trilhamos até agora, no capítulo anterior, a ideologia não aparecia como tal, não se colocava como foco das atenções de Lefort, estando presente de modo implícito, latente, encarnada, a comandar seu movimento de pensamento.

Quando se volta para ela, as pistas deixadas pelo autor acerca de seu entendimento parecem poucas, algo que se constata até mesmo pela palavra "esboço", presente no título de um de seus ensaios, anunciando que se trata de uma reflexão em processo de construção, de caráter provisório, aligeirada, feita "às pressas" como dá a entender neste mesmo artigo (cf. FH, [1974] 1979b, p. 296-297). Em certa medida, como discutiremos na seção seguinte, o contexto da época justifica a ânsia com a qual o autor se atém ao tema entre 1973 e 1974, momento em que o debate sobre o totalitarismo e a democracia adquire os contornos de uma fala ideológica, na perspectiva lefortiana, e no qual ele procura intervir. Ao mesmo tempo, no entanto, esta nos parece ser uma explicação que ilumina apenas uma parte do seu movimento de pensamento, pois estamos nos referindo a um tema caro àqueles que permaneceram no círculo marxista de reflexão como fizera Lefort por um tempo, o que nos deixa com uma questão: tendo sido trotskista, refletido de maneira indireta sobre a ideologia, em seus estudos anteriores, por que há esta recusa em falar sobre a ideologia, em estenderse em uma reflexão sobre ela justamente num contexto de debates ideológicos?

Este capítulo se constrói neste cenário, em face de sua exploração do tema. Somos movidos por aquilo que Lefort deixa subentendido e que nos mantém com uma incômoda percepção: ao colocar-se sob a exigência de pensar a ideologia, no momento em que a toma como "tema explícito de reflexão", sugere que não quis produzir "um saber sobre a ideologia" (ibid., p. 294). Diante deste enredo, somos novamente tomados de assalto, uma vez que a exploração do tema parece esvair-se, confirmar a hipótese de que o autor pôs um freio às suas reflexões. Ao mesmo tempo, no entanto, logo constatamos que esta negativa se dá como um enigma, pois visa lançar por terra qualquer expectativa acalentada pelo leitor em torno de uma definição que possa ser oferecida por Lefort, o que não quer dizer que não possamos encontrar em seus escritos a presença de enunciados que permitam apresentá-la, mas estamos constrangidos a assumir outro ponto de partida: que o tema não foi apreendido pelo autor como objeto, isto é, como conceito, como definição a ser explorada em busca de um saber positivo da 
ideologia. Ao esquivar-se desta reflexão, Lefort não apenas abre um novo caminho para o seu entendimento, como também nos esclarece sobre sua própria perspectiva: não quer permanecer nos debates conceituais, pois isto implicaria pensar a própria ideologia em sobrevoo, como um saber que sobrepaira, segundo os termos de Merleau-Ponty ${ }^{35}$, com vistas a defini-la como reflexo, como ideias dominantes, como córpus de teses, aparelho de crenças e, com isto, produzir um saber sobre ela, ou seja, um saber capaz de determiná-la, de fechá-la como significação adquirida, como determinação prometida ao conhecimento. Permanecer, então, no debate conceitual seria o mesmo que produzir um saber ideológico da ideologia.

Dessa maneira, então, ele se desvia da definição para pensar a gênese, o nascimento da ideologia. Lefort não realiza uma pesquisa histórica, ele procura compreender a origem da ideologia como um discurso que vem a ser engendrado em cada época, em cada aqui e agora e que, por sua vez, não se desprende do trabalho de pensamento que se dá em cada sociedade. Com isto, compreendemos que o desvio não é fortuito, ou seja, não implica ignorar o que é pensado em sua época sobre a ideologia, conforme veremos, mas marca um modo de pensar que quer chegar até ela por outra via: pelo entendimento das condições que possibilitam o seu surgimento por meio de uma compreensão da forma de sociedade, particularmente, pela instauração da sociedade moderna.

Os traços que caracterizam esta sociedade serão salientados e reconstruídos nos referenciais reunidos por Lefort para esta compreensão, os quais partem da literatura etnológica, da fenomenologia, das obras de Marx e de Maquiavel. Toda essa discussão nos remete, então, à ideologia tal como pensada por Lefort em suas três formas: burguesa, totalitária e invisível. Mostraremos este movimento até chegarmos a algumas considerações que vamos apresentar, as quais apontam para uma reflexão sobre a interligação entre o pensamento da política, o pensamento sobre a política - que será entendido como ideologia - e o pensamento do político tal como construído por Lefort e que não se desprende de cada forma de sociedade.

\footnotetext{
35 Como explicita Chauí, o pensamento ocidental ou "pensamento de sobrevôo" em Merleau-Ponty, é aquele que procura dominar e controlar totalmente a si mesmo e à realidade exterior. $\mathrm{O}$ sujeito cognoscente pode transformar o mundo em ideia ou pensamento, convertendo-o em representação do mundo (Cf. CHAUÍ, 1984, p. X). Ver principalmente as obras de Merleau-Ponty, A estrutura do comportamento (2006a) e Fenomenologia da percepção (2006b).
} 


\section{O debate da época: o problema de se partir do conceito}

Qualquer referência que se faça à ideologia, como sabemos, implica retornar à obra de Karl Marx ${ }^{36}$. De certa forma, Lefort também realiza este movimento, embora este se dê com o intuito de colocar em relevo a compreensão de que havia sido instaurado um debate propriamente ideológico sobre a ideologia em sua época, isto é, um debate marcado pela "degradação do conceito", por "representações falaciosas" responsáveis por recobri-la, de modo, então, que na sua perspectiva, o conceito não conservava mais os traços de sua significação primeira, tal como esboçada por Marx.

Lefort aponta, em linhas gerais, que o conceito havia se transformado tanto em um "projeto global de transformação da sociedade", o qual seria mantido por um partido - comunista ou fascista -, como podia expressar-se em termos de uma ideologia burguesa tal como definida por Marx, ou, ainda, como "ideias" que são defendidas por uma boa ou má “causa” (FH, [1974] 1979b, p. 296-297). Embora não seja possível definir quais são os interlocutores de Lefort nesta crítica, sabemos que ele se dirige às perspectivas de sociólogos e historiadores de sua época, bem como ao posicionamento de muitos marxistas que não conservavam mais em suas perspectivas o problema da clivagem entre uma ordem da prática e da representação, tal como evidenciada por Marx.

Dessa maneira, o debate lhe dá indícios de que há uma diferença entre o discurso de Marx e os discursos coletivos que acabaram por veicular um novo conceito

\footnotetext{
${ }^{36}$ Não é nosso propósito recuperar o debate sobre a ideologia, no que tange às múltiplas perspectivas que procuraram abarcá-la, mas é importante salientar que desde a Renascença, como explicita Bosi, já é possível encontrar modos de pensar que eram identificados como errôneos, atribuídos a preconceitos etnocêntricos, presente no relativismo de Montaigne, como fruto de maus hábitos cognitivos herdados da tradição e das convenções sociais (os idola de Bacon), as denúncias de Rousseau, quanto à submissão ao poder no bojo de contextos sociais iníquos, ou, ainda, os desvios da razão na história das nações que se pode encontrar nas visões de Vico ou de Hegel, lançadas contra certas tendências culturais de seu tempo (cf. BOSI, 2010, p. 61). Somente no século XIX é que será forjado o termo ideologia por Destutt de Tracy (1754-1836), o qual retomou as ideias dos clássicos das Luzes, especialmente Condillac e publicou o livro Elementos de ideologia (1801), o qual pensou a ideologia como nova disciplina filosófica, na qual as ideias podem ser alcançadas pelas sensações que estão em sua base. Considerado como ideólogo por Napoleão Bonaparte, o termo que fora cunhado por Desttut de Tracy no sentido positivo, passa a ter um viés negativo, pois passou a significar abstração, algo fora da realidade, uma perspectiva incapaz de enfrentar os problemas concretos das conjunturas políticas. Essa nova significação passa a fazer parte do vocabulário, como indica Löwy (2009, p. 12), sendo retomada por Karl Marx um tempo depois. Para Bosi (2010), temos, então, em Marx, um verdadeiro divisor de águas com relação ao entendimento da ideologia, através de sua crítica das ideologias burguesas. A partir de então, diferentes autores e perspectivas são apresentadas, o que se deixa apreender pelos trabalhos que visam reorganizar o debate, como o estudo de Leandro Konder (2002), Bosi (2010), Eagleton (1997), para citarmos apenas alguns, diante da infinidade de obras sobre o assunto.
} 
de ideologia. O que, de imediato, o incitaria a buscar a significação objetiva do conceito naquele autor e, com ele em mãos, passar a apontar o que há de diferente entre os dois modos de discurso. Ao mesmo tempo em que Lefort afirma que o conceito utilizado por seus contemporâneos ignora uma clivagem fundamental entre a ordem da representação e da prática, ele também interrompe a fala e nos dirige para uma compreensão que nos prende ao "regime do discurso", ou seja, à ideia de que mais importante não é permanecer no debate conceitual e, sim, compreender a construção do discurso de Marx sobre a ideologia, por um lado, e, de outro, as interpretações de sua teoria que tiveram o efeito de denegar aspectos fundamentais dela, criando uma cegueira ideológica sobre o seu significado.

Tendo em vista este cenário, nos perguntamos o que explicaria, então, a ausência de um debate conceitual sobre a ideologia nos estudos de Lefort, uma vez que procura salientar justamente uma falha de interpretação que remete à significação do conceito, tal como apresentada por Marx? E, ainda, por que o autor se desvia deste debate para deter-se no discurso da obra de Marx e nos discursos sobre a obra de Marx, presente no marxismo e nas diversas interpretações que propiciaram certos estudos sociológicos e históricos? Vejamos, então, primeiramente, o que explica aquela ausência nos estudos de Lefort sobre este tema para, depois, retomarmos a sua visão sobre as consequências políticas e intelectuais desta "cegueira ideológica", isto é, das interpretações da obra de Marx que resultaram numa certa compreensão a respeito da ideologia. Argumentaremos, mais adiante, que esta "cegueira" é vista por Lefort como um entrave para o entendimento da democracia e do totalitarismo em sua época.

\subsection{A recusa em partir do conceito de ideologia}

No entendimento da relação entre conceito e teoria, o conceito pode ser definido como aquele que se constrói no âmago de uma teoria. Elaborado nas suas fronteiras, ele adquire a possibilidade de destacar-se dela, justamente porque condensa um saber teórico, ou seja, o conceito "representa a própria Teoria", de acordo com Lefort (FH, [1973] 1979b, p. 262), devendo permanecer como um conceito determinado, plenamente captável, como "órgão de inteligibilidade" da Teoria (ibid., p. 262). Esta, por sua vez, nasce com a pretensão de oferecer-se como o "lugar do conhecimento", onde o pensamento faz um retorno sobre si mesmo e se coloca no 
princípio do real, ou seja, se afirma como o começo, onde o conhecimento figura o que pode ser denominado como real. Nessa perspectiva, a teoria importa para dentro de si toda a exterioridade na qual se move a experiência como um todo.

O conceito, portanto, "é o apreensível da Teoria" e se oferece ao leitor como algo que a torna inteligível. Nesse sentido, ele é sinônimo de fechamento, determinação, de um saber lacrado e, por isso, permanecer em um debate conceitual equivale a um movimento de determinação em determinação que nos remete à Teoria, a segurança de atingir um fundamento para o mundo real, constituindo uma operação ideológica. Temos, então, a imagem de certo saber que se coloca como garantia daquilo mesmo que designa, visto como idêntico, ao mesmo tempo real e inteligível, indicando algo fora dele, isto é, criando uma exteriorização que o remete ao objeto ${ }^{37}$. Trata-se, então, de uma ilusão, de uma fantasmagoria, na qual o pensamento é apreendido como algo separado em relação ao real, erigindo-se como o começo onde nasce o conhecimento. Ilusão simétrica seria partir do real como se pudéssemos tocá-lo em sua positividade, entendido como externo ao pensamento, na acepção de fato social ou de estrutura social, cujo pressuposto é o de que contém um saber que não pode existir fora de si mesmo.

Estas duas ilusões são apontadas por Lefort: nem é possível buscar o nascimento da ideologia nos fatos nem se trata de partir do conceito fixado na teoria marxista. A ideologia não pode ser pensada como conceito que, reenviada a esta teoria, nos daria acesso a uma definição capaz de colocar outros conceitos e a própria realidade à prova. Se isso fosse feito, o debate permaneceria fechado em querelas conceituais, além de incitar a uma disputa em torno da definição que melhor abarcaria os contornos da realidade. Ao invés disso, Lefort nos leva ao "lugar da obra", isto é, ao lugar onde Marx pôde conceber a sua compreensão da ideologia, em que fez a experiência de uma abertura a algo até então impensado - ao não conhecimento da ideologia. Partindo dessa visada de Marx, Lefort procura se aproximar mais intimamente, pois quer refazer os passos seguidos por este filósofo, o modo como ele fez surgir a ideologia em seu pensamento, guardando na memória o seu percurso para, então, reabri-la segundo outro entendimento, pensando a experiência de seu próprio tempo. Dessa maneira, ao invés de

\footnotetext{
${ }^{37}$ Esta perspectiva explica um aspecto do pensamento de Lefort, na medida em que o autor evita definir algumas das noções que utiliza em seus artigos, entre as quais está a própria ideologia, como temos discutido. Outra noção central na obra de Lefort é a noção de simbólico, a qual não possui uma definição exata (Cf. POLTIER, 1998, p. 184). É importante salientar que se trata de uma escolha do próprio autor, no sentido de manter aberto o pensamento e, portanto, não pode ser compreendida como ausência de rigor teórico ou algo do gênero.
} 
um movimento determinado que se assegura do conceito, Lefort opta pela indeterminação, passando pelas questões abertas por Marx e que o fizeram chegar até a ideologia. É por isso que, ao invés de recusar totalmente a visão deste autor, ele parte das oscilações, das contradições como movimentos de seu pensamento que se abrem à indeterminação ${ }^{38}$.

Já o dissemos, contudo, que nosso objetivo não é submeter as hipóteses de Marx à verificação, confrontando-as com fatos historicamente estabelecidos. Não são hipóteses que podemos extrair da obra de Marx; ele nos dá o poder de interrogar porque seu pensamento não se deixa reduzir às respostas aparentes que acaba, aqui e ali, por formular. Digamos até mesmo, mais francamente, que a verdade do pensamento de Marx não está em causa. (FH, [1973] 1979b, p. 277)

Nesse sentido, Lefort assume outra perspectiva: da mesma forma que Marx, Lefort não procura ver a ideologia como um objeto e, sim, compreendê-la pelo modo como ela se instaura. Pensar a ideologia, então, não se desprende de uma experiência que se dá no mundo e na relação com a obra de pensamento ${ }^{39}$. É assim que Lefort lança suas próprias questões na esteira de Marx, procurando pensar o social, o seu aqui e agora.

Esta última observação remete-nos ao próximo tópico que abordará o social como Ser Social, na perspectiva de Lefort, para discutir o nascimento da ideologia na forma de sociedade moderna. Antes de passarmos a esta discussão, gostaríamos de fazer breves indicações sobre o que teria levado Lefort a fazer uma crítica ao debate de sua época, uma vez que sua preocupação, conforme vimos, não era conceitual e, sim, investida no deciframento daquilo que este debate estava denegando e com as consequências políticas desta denegação, no que tange o entendimento da democracia e do totalitarismo. Para tanto, nos remetemos a três de seus prefácios, os quais colocam em relevo a sua crítica ao pensamento ideológico.

\footnotetext{
${ }^{38}$ Lefort encontra, na obra de Marx, a diferença entre os discursos míticos e religiosos responsáveis por veicular uma ordem universal nas sociedades pré-capitalistas e o discurso presente na sociedade burguesa, o qual se define como ideológico. Nesse sentido, ele está atento à presença de duas ideias do imaginário que Marx evidenciou.

39 "Obra de pensamento" é uma expressão importante no pensamento de Lefort, pois ela exprime uma experiência vivida por cada autor que frequenta a obra de outros autores enquanto leitor e pensa seu próprio mundo. Nesta imbricação nasce o seu pensamento, que não se dissocia das ilusões de sua época, dos acontecimentos, de outros pensamentos com os quais os seus se embaralham, dando testemunho de um irrefletido para chegar, então, à reflexão. Ela contém uma natureza simbólica, pois cria um espaço de significações que se afirma como um mundo que pode se dar pela linguagem tecida pelo autor em sua narrativa. Esta noção de "obra", conforme veremos, é de fundamental importância no entendimento da ideologia e da crítica à ideologia que apresentaremos no quarto capítulo.
} 
O primeiro prefácio crítico escrito por Lefort está presente no livro Un homme en trop. Réflexions sur 'L'Archipel du Goulag' (1976c), mantendo uma articulação com o prefácio presente em Éléments d'une critique de la bureaucratie (1979c). No primeiro texto, Lefort rearticula o debate dos anos 1970 ao dos anos 1950 sobre a natureza totalitária do regime soviético, afirmando que há o seu renascimento e sua continuidade $^{40}$. A diferença, no entanto, está no fato de que, enquanto na década de 1950, havia a negação dos testemunhos sobre os campos de trabalho, sobre o terror praticado no regime soviético, duas décadas depois, a intelligentsia realizava uma denegação, ou seja, preferia considerar que o terror havia sido necessário para garantir a revolução. Nesse sentido, ocorre a "cegueira da esquerda", pois a URSS escapa à crítica e, como vemos no segundo prefácio que indicamos, escrito em 1979, as reflexões de Lefort mantêm este mesmo tom, se referindo à existência de uma nova linguagem detida por esta esquerda, a qual consegue neutralizar todo o sentido crítico presente na concepção "totalitarismo". Dessa maneira, Lefort está atento à resistência por parte da intelectualidade francesa em aceitar todos os registros de informação e de reflexão sobre a sociedade totalitária, compreendendo esta postura como aquela que permanece inserida no quadro de reflexões marxista, em cujo discurso, calcado na ideia de revolução, é incapaz de reconhecer a existência do totalitarismo.

No prefácio de $A$ invenção democrática: os limites da dominação totalitária (ID, 1981a), essa mesma questão é retomada, mas no sentido de acrescentar que os esquerdistas acabaram por denegar o próprio sentido da denegação (ID, 1983a, p. 25). Com isso, ressalta a importância de suas reflexões que se mantêm articuladas ao contexto ideológico, ressaltando que nem a democracia, nem o totalitarismo haviam sido plenamente compreendidos. Esse ponto de vista é colocado em relação à fala de um crítico seu, o qual escreveu no jornal Le Monde em tom inquisitivo: "a causa [totalitária] já não está compreendida?” (ibid., p. 17), ou seja, que já era possível compreender o que teria propiciado o totalitarismo e que, no fundo, as análises de Lefort publicadas em $U n$ homme en trop, seriam dispensáveis. Atento a essas considerações, Lefort enfatiza ainda mais o significado da relação entre democracia e totalitarismo, tanto para dizer que o ódio à democracia, entendida pelos intelectuais de esquerda exclusivamente como democracia burguesa, lhes escondeu a "verdade da democracia" (ibid., p. 25), como

40 Nos anos 1950, entre os expoentes deste debate estão Sartre e Merleau-Ponty. Para maior aprofundamento sobre o desdobramento deste debate e o papel da intelectualidade de esquerda nos anos 1970, ver Christofferson (2004). 
para evidenciar que o entendimento da vida política de nosso tempo requer uma interrogação sobre o totalitarismo.

Esses três prefácios, portanto, dão o tom da crítica dirigida por Lefort em seus artigos e evidenciam que sua grande preocupação esteve atrelada com as representações construídas em sua época sobre a democracia e sobre o totalitarismo, atentando para o problema da denegação política que é indissociável da ideologia, conforme discutiremos à frente.

\section{Forma de sociedade e ideologia}

Uma vez que para Lefort a ideologia não pode ser compreendida pela sua definição, pelo conceito, pois este é intrinsecamente ideológico, somos levados ao problema da sua genealogia, do seu nascimento. De imediato, nos deparamos com a ideia de que haveria um ponto de origem onde a ideologia teria nascido. Lefort apontanos uma direção quando afirma que "é suficiente buscar os sinais do nascimento da ideologia no fim da Idade Média em uma sociedade que se destacou do Feudalismo e se organizou em função de novas posições de classe" (FH, [1973] 1979b, p. 251), ou, ainda, na sociedade industrial do século XIX vista pela perspectiva de Karl Marx. Estes dois pontos na história deixam-se descobrir na obra de Lefort como aqueles onde encontramos a gênese da ideologia, o que nos suscita, por sua vez, uma indagação sobre a origem à qual ele nos reenvia, pois ela se deixa identificar simultaneamente na sociedade florentina do fim do século XIV e início do século XV e que se fez presente na obra de Maquiavel no início do século XVI, e na sociedade burguesa pensada por Marx. Por consequência, somos levados a indagar: por que o autor nos remete a dois cenários vinculados às interpretações destes dois pensadores? Por que a ideologia é remetida a uma origem, quando, na verdade, são postuladas duas gêneses, relacionadas a duas sociedades distantes no tempo?

É nesse ponto que se revela a diferença da argumentação de Lefort em relação a seus contemporâneos, pois não se trata de explicar a ideologia nem a partir do conceito nem por meio dos fatos históricos que a teriam propiciado, mas sim pelo entendimento de que ela nasce e renasce em cada aqui e agora na sociedade histórica. Este movimento característico da ideologia circunscreve-se a um tipo de sociedade ou, melhor, a uma forma de sociedade que tem a qualidade de ser histórica. 
A expressão "forma de sociedade" tem em vista uma diferenciação com relação à perspectiva sociológica e marxista, as quais procuraram compreender o social como sendo da ordem do fato, objetivamente analisado em suas partes ou, ainda, como um conjunto de relações determinadas pela esfera econômica. Toda a argumentação crítica de Lefort em relação a estas perspectivas procura evidenciar a importância da dimensão simbólica, a qual tem o efeito de suscitar no leitor certa reserva e algumas desconfianças, pois à primeira vista, esta dimensão parece nos remeter a uma ordem destacada do real, em que são compostas as imagens e as representações sobre o social, o que nos leva a compreender a relação que elas mantêm entre si e com o plano da realidade, perscrutando a função, a instrumentalidade que possuem os signos no conjunto das relações sociais. Neste viés interpretativo, seria oportuno questionar, como fez Salinas Fortes (1979), se Lefort estaria reabilitando a velha transcendência "batizada com um novo nome, mascarada sob o título de ordem do imaginário ou ordem simbólica (...)”(SALINAS FORTES, 1979, p. 10).

Perguntar se o simbólico é ou não transcendente, já implicaria uma determinação, um fechamento do que significa o simbólico para Lefort, porém isso é algo que soa estranho a seu modo de pensar que procura sempre manter em aberto as questões. Por isso, consideramos que a questão colocada por Salinas Fortes poderia, talvez, ser formulada da seguinte forma: Como o simbólico se apresenta nas formas de sociedade? Ao modificarmos a pergunta, estamos em condições de refletir que, em sociedades regidas pelo mito e pela religião, o simbólico pode ser entendido como um fenômeno transcendente, enquanto que, na sociedade histórica, ele pode tornar-se uma transcendência, justamente porque sempre existe a possibilidade do retorno ao discurso mítico e religioso, assim como um discurso imanente ao social, como foi o caso do discurso totalitário para imprimir um sentido ao real.

[...] tudo que vai no sentido da imanência vai no sentido da transcendência, tudo que vai no sentido de uma explicitação dos contornos das relações sociais vai no sentido da interiorização da unidade, tudo que vai no sentido da definição de entidades objetivas, impessoais, vai no sentido de uma personalização dessas entidades. (PP, [1981b] 1991, p. 294).

Por ora, ressaltamos a compreensão de que o simbólico tende a ser transcendente, algo que ficará mais claro no momento em que discutirmos o lugar vazio do poder na democracia e a possibilidade sempre aberta para que um discurso imanente 
crie as condições de uma transcendência, pela ocupação daquele lugar vazio, operando, por conseguinte, o fechamento do social. Há, nessa perspectiva, tendências e a possibilidade sempre aberta para o transcendente, por meio do poder, lócus simbólico, e da ideologia, enquanto discurso a constituir o imaginário da sociedade moderna.

Poder-se-ia perguntar se no pensamento de Lefort há uma definição de simbólico. Mas, não por acaso, o autor também não o define completamente, como já salientado por Poltier (cf. POLTIER, 1998, p. 184). A resposta exige que se percorra certo caminho, pois a dimensão simbólica não pode ser plenamente compreendida se não for reenviada ao significado atribuído por Lefort ao social. Percorrer esta trilha, conforme veremos, levará nossa pesquisa ao entendimento de algumas noções-chave presentes na obra de Lefort, como "instituição do social", "forma de sociedade", "simbólico", "divisão social” e, em especial, "ideologia".

Para Lefort, o social não é da ordem do fato, visto como coisa em si oferecida ao entendimento, mas enquanto Ser social (FH, [1978c] 1979b, p. 15), como aquele que não coincide consigo mesmo, no espaço e no tempo, estando implicado no eterno questionamento de si. Para compreendermos esta não coincidência, é importante nos remetermos brevemente a Merleau-Ponty, o qual pensou o Ser nesta perspectiva antes mesmo de Lefort, ou seja, como não idêntico a si mesmo.

Segundo esta visão, o Ser é reversibilidade, pois não pode ser entendido como estando fora - no mundo externo, na linha do empirismo -, nem dentro, de acordo com o intelectualismo que compreende o Ser como recepção passiva dos estímulos que vêm do “real”. Ao mesmo tempo, o Ser também não é síntese do interior e do exterior como é possível compreender por meio da noção de corpo, pois o tocar e ser tocado faz parte de uma só experiência, na qual não é possível determinar quem toca e quem é tocado. Nesse sentido, segundo Bernard Flynn, Merleau-Ponty faz uma crítica ao empirismo e ao intelectualismo, pois estão calcados na separação sujeito-objeto, uma vez que tem em vista a descoberta do corpo reflexivo e do conceito de carne como "arquétipos do Ser" (FLYNN, 1984, p. 13). Há, portanto, divergência, não coincidência do Ser consigo mesmo e com o fora, um movimento de ir e vir nestas dimensões, abrindo caminho para a ideia de que ele é indeterminação, Ser não positivo, pois tem dobras, lacunas ${ }^{41}$.

\footnotetext{
41 Sobre essa compreensão do Ser encarnado, segundo Merleau-Ponty, conferir A estrutura do Comportamento (2006a) e Fenomenologia da percepção (2006b).
} 
Em Lefort, estas noções de corpo e carne são mobilizadas para pensar o Ser do social. Para ele, da mesma forma que a carne não está em lugar algum, em tempo algum, pois não está no real, o social também não pode ser entendido como algo previamente determinado, visto como um objeto, mas sim como aquele que se faz e refaz em cada aqui e agora, sob a experiência que fazem os homens de sua diferenciação e de sua articulação social. Assim, o social não possui uma essência predefinida, um fundamento, sendo compreendido como indeterminação e como nãocoincidência $^{42}$. Como sintetiza Leydet (1993), a noção de carne, remetida como está por Lefort ao entendimento do social e da história, impede-nos de pensar que há uma origem, um fundamento, pois o começo se faz aqui ou lá (LEYDET, 1993, p. 352)

Assim, qualquer agrupamento humano, em cada época, encontra-se às voltas com uma questão originária que não pode ser possuída, nem está em pleno alcance dos sujeitos sociais, mas comanda secretamente as articulações de uma sociedade. Podemos dizer que esta questão é de ordem metassociológica (cf. FH, [1974] 1979b, p. 308), pois ela é instituinte e, portanto, conduz, de maneira não aparente, um jogo de respostas que vem constituir uma forma de sociedade, o conjunto de suas articulações e relações internas e com o fora, isto porque o social é pensado em termos de seu limite, na relação que mantém consigo mesmo e com o que o ultrapassa ${ }^{43}$.

Assim, toda sociedade está atrelada a uma questão-enigma ou, como denomina Lefort, ao "enigma da instituição" (DEP, [1987] 1999a, p. 324 e FH, [1974] 1979b, p. 314) que guarda em si a ideia de uma origem, de um nascimento da sociedade, mas que não pode ser localizado em um ponto pré-social, fora do próprio tempo e de seu espaço. A singularidade deste enigma está na compreensão do deciframento, no trabalho do pensamento e da ação realizado pelos sujeitos sociais, de modo que o social pode ser entendido como obra ou, ainda, como “instituição" na acepção do verbo "instituir".

\footnotetext{
${ }^{42}$ Ao compreender o social desta forma, Lefort tem em vista uma crítica ao marxismo que mantém uma concepção positiva da sociedade e de seu desenvolvimento histórico, vendo-a sob a perspectiva de uma realidade determinada pela esfera econômica. Como afirma Poltier (1998, p. 90), Lefort rompe com a teoria marxista para pensar uma nova concepção de coexistência humana, pois esta teoria contém uma concepção de realidade que vê esta coexistência como algo prévio e independente de sua manifestação.

${ }^{43}$ Para Lefort, o social é compreendido como "espaço social", pois ele se mantém como questão sobre seu limite ou seu "fora" (cf. FH, [1974] 1979b, p. 311). Isso significa que toda sociedade pode ser compreendida como uma resposta dada a esta questão, contribuindo para engendrar diferentes tipos de sociedade, como é o caso da sociedade moderna, referida a seu espaço interno e não mais ao "fora", a outro lugar, representado na figura de Deus, deuses que caracterizam as sociedades regidas pela religião e pelo mito.
} 
Este último termo, não o tomo mais em sua acepção convencional, mas no sentido que guarda a força do verbo. Noção, literalmente inconcebível, pois ela faz signo em relação a uma origem do social e que ela barra simultaneamente o caminho na direção da origem, interditando a representação de um estado de coisas pré-social. Mas noção da qual nós não podemos passar porque, tão distante quanto nós nos remontemos no tempo, e qual seja a direção de nossa curiosidade, todo agrupamento humano nos parece portar o traço de uma elaboração em virtude da qual suas divisões internas, a começar pela mais elementar, a diferença dos sexos, fazem sentido para cada um de seus membros. Tanto a ficção liberal de indivíduos vivendo em um estado de natureza, quanto a ficção durkheimniana de um grupo que retiraria de sua existência material a representação de uma ordem da natureza e de coisas fazem desconhecer a primazia do simbólico. (LT, [2000] 2007, p. 984)

A instituição do social, portanto, remete-nos a um conjunto de significações constituídas pelos homens a fim de darem sentido às suas ações, às suas condutas, sendo algo que não se desprende do trabalho do pensamento e da ação que se defronta sempre com a mesma questão-origem. Assim, afirma Lefort, trata-se de uma elaboração que atesta toda sociedade política, realizada pelos sujeitos que procuram decifrá-la, contendo "uma interrogação sobre o mundo e sobre o Ser como tal" (PP, [1981b] 1991, p. 255). Nessa perspectiva, as respostas produzidas pelos homens, em cada época, podem ser entendidas como um deciframento da questão-enigma remetida como está à diferenciação, isto é, à divisão social $^{44}$. Elas compõem, por sua vez, um discurso instituinte da ordem social que pode remeter-se ao fora, isto é, a uma potência exterior ao social, como é o caso do discurso mítico, religioso que cria um fundamento para a sociedade, remetendo-a a deuses, a Deus, e não podendo ser colocado em questão, definindo um gênero de historicidade que a mantém petrificada. $\mathrm{O}$ discurso instituinte também pode permanecer como discurso interrogativo, isto é, desdobrar-se em múltiplos questionamentos que, na tentativa de decifrar o significado da ordem social, são capazes de manter a questão-origem aberta, este é o caso da sociedade histórica. Nesta sociedade ainda, o discurso instituinte pode dobrar-se em um discurso da certeza, necessariamente determinista, fechado, afirmando-se como tese sobre a ordem social. Este discurso fechado, que segue as linhas do discurso instituinte em seu formato interrogativo, conforme veremos mais à frente, é a ideologia.

\footnotetext{
${ }^{44}$ Isso significa que cada sociedade pode ser compreendida como um encadeamento de respostas, como afirma Lefort na interpretação da obra de Maquiavel (cf. LTO, 1986c, p. 513), cujas expressões são individuais e coletivas. Essas respostas constituem sempre possíveis, pois podem ou não obliterar o desejo de liberdade. Temos, então, a ditadura ou a democracia como formas de sociedade que se compreendem por este jogo de possíveis, significando que nem uma nem outra podem ser vistas como formas puras, estanques, distanciadas, mas que contém em si mesmas a possibilidade latente de sua reversão.
} 
Cada tipo de sociedade, portanto, pode ser compreendido como uma criação, como um desdobramento de representações, significados que dão acesso ao mundo. Quando pensamos o social desta maneira, então, estamos considerando uma dimensão simbólica, pois se refere a uma reflexão voltada para o esquema diretor de instituição da sociedade, seu modo de instituição, de engendramento.

Assim, toda forma de sociedade nasce como resposta ao enigma de sua diferenciação, sendo que o deciframento vem a ser a elaboração de um discurso que está “inscrito na divisão" (FH, [1974] 1979b, p. 309). Dessa maneira, devemos entender que a divisão é "originária", engendradora do espaço social, de formas específicas de historicidade, não sendo vista por Lefort como da ordem do real - como divisão entre os sexos, como "repartição empírica dos homens na operação de produção" (ibid., p. 307), tal como pensado por Marx, mas como pensamento, linguagem da divisão. Ela é, ao mesmo tempo, "uma elaboração e uma experiência da condição humana" (DEP, [1987] 1999a, p. 323) na qual permanecem indissociáveis sua forma e sua representação. Há, portanto, uma linguagem que nomeia, define, descreve e que representa ao mesmo tempo a divisão, criando uma imagem destacada dela mesma, uma "quaserepresentação" sobre a divisão que pode tanto reconhecê-la como denegá-la. Portanto, cada forma de sociedade cria uma representação de sua unidade, a qual pode ser definida em termos de uma unidade no reconhecimento elou denegação da diferença que, como veremos adiante, se caracterizam, respectivamente, como sociedade estagnante e sociedade histórica, as quais são pensadas por Lefort sob o ponto de vista de uma interligação entre elas.

É importante dizer que esta discussão parte do pressuposto de que qualquer agrupamento humano só pode existir se forjar para si mesmo uma ideia de unidade, fazendo com que toda forma de sociedade se constitua pelo modo de articulação de sua divisão segundo esta ideia, nos contornos de uma "comunidade imaginária", como não coincidência $^{45}$. Nela estão embutidos os signos de sua identidade social, de sua essência que não podem ser pensados como projeções oriundas da esfera "real", mas como uma ordem simbólica, em que as práticas e as representações encontram-se articuladas pela fala humana. Não se trata de pensar uma lógica das ideias independentes, nem cair no

\footnotetext{
${ }^{45}$ Lefort parte de Marx: "Marx dá a entender que uma sociedade não pode referir-se a si mesma, existir como sociedade humana, a não ser sob a condição de forjar para si mesma a representação de sua unidade" (FH, [1974] 1979b, p. 304). Aqui reside a ideia de não coincidência.
} 
empirismo de Marx, mas de compreender que toda e qualquer experiência é, simultaneamente, prática e representação que se dá no mundo.

Devemos ter em mente que toda esta discussão está vinculada à instituição do social, isto é, a instituição de uma forma de sociedade, da vida social, do que outrora se denominou Cidade. O social visto por Lefort como "instituição", na acepção do verbo "instituir" nos remete à ideia de uma origem do social que ocorre, na verdade, como acontecimento (événement), isto é, como uma "fonte de sentido" que solicita o pensamento, porque não pode ser visto como um ponto de passagem, determinado na duração histórica, isto é, como um fato, mas como aquele que condensa em si mesmo o próprio tempo e irradia em todas as direções do passado e do futuro, como nos diz Lefort (CA, [1963b] 1978f, p. 60), constituindo um jogo social que se processa em vários planos - estético, político, pedagógico, econômico, etc - ao mesmo tempo ${ }^{46}$.

Cada forma de sociedade pode ser pensada como um acontecimento, como um jogo interno de respostas como é o caso da democracia, do totalitarismo e de outras formas como as que foram estudadas pela etnologia. Elas asseguram para si mesmas a figuração de uma essência imaginária da comunidade. É por isso que toda forma de sociedade é entendida como sendo da "ordem do simbólico", ou seja, como um sistema no qual as oposições de toda ordem - entre agentes sociais, classes, Estado-sociedade civil - podem ser identificáveis e articuláveis entre si e, ao mesmo tempo, implicam uma relação desses agentes sociais com a representação.

A eficácia da representação, no entanto, somente pode ser garantida pelo poder, pois ele é a "figura" que torna visível um modelo de organização social (cf. ID, [1980a] 1983a, p. 79). Ele é compreendido como polo simbólico, sendo balizado pela divisão “originária” (DEP, [1987] 1999a, p. 309). É ele quem dá forma à sociedade, estando ligado às duas questões-chave do social: a questão ligada à divisão interna, a qual engendra um discurso capaz de desdobrar-se, e a questão da divisão com o "fora". A representação que os homens concebem sobre a divisão interna não se desprende do poder, uma vez que ele figura a comunidade imaginária, confere a unidade e a identidade sociais. Porém, ele pode tanto ser um polo simbólico referido a uma potência outra, localizável fora do social e, portanto, permanecer atrelado a uma palavra

\footnotetext{
${ }^{46} \mathrm{O}$ acontecimento para Lefort é aquele que está presente na sociedade histórica, como veremos adiante, pois ele é "potência de desordem", capaz de fraturar e desfazer o próprio tempo e criar o desconhecido (cf. PP, [1982c] 1991, p. 319).
} 
transcendente - mítica, religiosa -, de tal forma que o poder dá sinais de um "fora" do social (PP, [1981b] 1991, p. 262), como também - e, aqui, encontramos a outra possibilidade de resposta - pode abolir esta potência outra, mas não sua figura (ibid. p. 267) e aparecer, então, simultaneamente como engendrado pela divisão social e como fundador do social. Cada forma de sociedade, então, decifra-se segundo a resposta dada a estas duas questões, articuladas como estão à forma e à representação ${ }^{47}$, referidas como estão ao poder, enquanto polo simbólico. Dessa maneira, o entendimento do poder em Lefort está remetido ao enigma desta articulação exterior-interior (ibid., p. $262)^{48}$.

Toda sociedade, então, contém uma "matriz política" (ID, [1980d] 1983, p. 9899) na qual o poder é constitutivo e é fruto de uma elaboração coletiva, isto é, de uma "escolha existencial", como afirma Poltier, capaz de criar o "nós coletivo" (cf. POLTIER, 1998, p. 55). Esta matriz, no entanto, não é visível, pois é simbólica.

Toda discussão que fizemos até agora foi no sentido de apontar uma visão geral das questões que perpassam o entendimento de uma forma de sociedade. $\mathrm{Na}$ obra de Lefort, esse entendimento desenrola-se com vistas a manter sempre um tipo de sociedade em perspectiva comparativa (cf. POLTIER, 1998, p. 194 e 197), o que requer a comparação entre diferentes dispositivos simbólicos, procurando compreender cada sociedade como criação em relação ao problema de sua coexistência, tendo em vista as transformações que afetaram a determinação-figuração do poder ${ }^{49}$. Este autor também afirma que Lefort mantém, desde seus estudos etnológicos, uma vontade comparativa de esclarecer uma sociedade pela outra, buscando encontrar "a bifurcação decisiva entre uma e outra" (ibid., p. 49). Nesse sentido, há uma relação de parentesco entre as formas de sociedade, enquanto pares reflexivos, pois toda significação que se busque atribuir a uma forma, não se desprende do entendimento daquela em relação à qual ela pôde se constituir, tal como na relação entre Antigo Regime e democracia e, esta, por sua vez, em relação ao totalitarismo. Cada sociedade também pode ser vista compondo "figuras cortadas de um mesmo fundo" (LTO, 1986, p. 497), pois participam da mesma história,

\footnotetext{
${ }^{47}$ A forma, na linguagem de Lefort é mise en forme e a representação mise en scène. Para tanto, conferir alguns artigos em que o autor explicita essas noções (PP, [1983b] 1991, p. 26 e [1981b] 1991, p.254-255). ${ }^{48}$ No Le travail de l'oeuvre Machiavel (1986c), Lefort compreende pela leitura dos Discorsi de Maquiavel que uma sociedade mantém uma relação com sua divisão interna e com sua divisão com o fora. Para tanto, ver Lefort (LTO, 1986c, p. 553-554).

${ }^{49}$ Poltier faz, ainda, uma indicação importante. Ele afirma que Lefort diferencia forma de sociedade de forma de governo e que, dessa maneira, pode fazer a defesa da democracia e criticar a ordem instituída (cf. Poltier, 1998, p. 195-196).
} 
à medida que são confrontadas ao mesmo enigma da instituição, podendo criar respostas diferentes nas quais o social torna-se histórico ou petrificado. Para Lefort, mais importante do que detectar os fatores que explicam a passagem de uma forma a outra é compreender os sinais de um remanejamento das relações culturais anteriores, de um reinvestimento que ocorre no âmbito de uma nova experiência que ocorre no mundo, no sentido de que cada sociedade não nasce do zero, pois se constitui como herança (DEP, [1987] 1999a, p. 326).

Da mesma forma, para o entendimento da ideologia, a reflexão também ocorre por um movimento comparativo, ou seja, para compreendê-la devemos colocar em perspectiva dois tipos de sociedade: a sociedade histórica e a sociedade estagnante, "sem história". No capítulo anterior, vimos que a atenção de Lefort esteve voltada para alguns estudos etnológicos. Havia uma intenção presente nestas leituras: compreender as formas da história, ou seja, cada sociedade como aquela que cria um modo de ser no tempo, revelando gêneros de historicidade que podem caracterizar-se por um agenciamento contra a história ou pelo consentimento à história ${ }^{50}$.

Vejamos, primeiramente, algumas características que diferenciam estas duas formas de sociedade e o significado do surgimento da ideologia para, a seguir, nos concentrarmos em entender o nascimento da ideologia na sociedade histórica a partir de dois cenários: a Florença de Maquiavel e a sociedade burguesa de $\operatorname{Marx}^{51}$, em que o autor tem em vista a mesma problemática, mas agora procura colocar em relevo o imaginário da sociedade histórica com o objetivo de pensar a ideologia como nascimento de um discurso sobre a política ${ }^{52}$.

\footnotetext{
${ }^{50}$ Lefort compreende a História não como um conjunto de fatos, mas como acontecimento, os quais modificam a forma da experiência vivida pelos homens e irradia em todas as direções do tempo presente, passado e futuro -, compondo, então, uma relação com o Ser do social.

${ }^{51} \mathrm{Na}$ obra de Lefort, a referência a Max e Maquiavel é constante em seus artigos, mantendo-os como interlocutores privilegiados, pois ambos têm como núcleo de seus pensamentos a questão da divisão social, com a diferença de que Marx buscou para ela uma solução, enquanto Maquiavel a vê como "boa desordem".

52 Com isto, gostaríamos de demarcar uma diferença importante. Nos estudos etnológicos, dá-se a formação de uma démarche, isto é, de um movimento de pensamento em que a sociedade moderna ainda não é colocada em relevo, estando apenas no horizonte de pensamento de Lefort, com a intenção de dirigir o seu olhar para certos estudos, uma vez que procura salientar as características do agenciamento contra a História presente nas sociedades que os etnólogos nos deram a conhecer. Elas são vistas como janelas que permitem o entendimento de sua própria sociedade. Além disso, o modo de proceder do etnólogo também lhe chama a atenção, pois tudo o que vem a nomear como real e imaginário não pode se desprender do ponto de vista dos "nativos" da sociedade em questão. Dessa forma, os aspectos políticos, sociais que virão a compor seu entendimento acerca do imaginário da sociedade histórica serão
} 


\subsection{Forma de sociedade, história e ideologia}

Sabendo que cada forma de sociedade elabora uma resposta para a questãoorigem, vejamos, por exemplo, o caso das sociedades regidas pelo mito e pela religião, denominadas por Lefort como "sociedades sem história". Nelas, a resposta dada é constantemente reenviada a um polo externo - a deuses, Deus - de tal forma que o arranjo social se dá como um "invisível materializado", ou seja, as relações sociais como um todo, são vistas a partir de um lugar "fora" do espaço social, materializando aquilo que não pode ser visto, questionado pelos homens, mas que rege a sua vida social. A resposta, portanto, constitui a organização da sociedade que é feita de uma afirmação que não pode ser contestada, pois está alicerçada nas crenças e costumes e comandada pela tradição. Dessa maneira, a sociedade apreende-se no modo de uma certeza mítica, religiosa, sobre o significado do social. O discurso instituinte, portanto, desdobra-se em um discurso mítico, religioso $^{53}$ que não pode ser questionado, justamente porque o discurso nutre-se de uma potência externa, invisível.

Nas sociedades onde se operou uma quebra com esta ordem transcendente - a sociedade moderna ou sociedade histórica, segundo Lefort -, a questão-origem é respondida segundo outra interpretação, pois as respostas não reenviam a um polo exterior, mas ao próprio espaço social. Dessa maneira, seu discurso instituinte torna-se um discurso interrogativo, ou seja, ele incorpora e mantém a questão-origem, fazendo com que a sociedade histórica se constitua como sociedade da interrogação. A despeito das respostas formuladas pelos homens, em cada tempo histórico, há um constante reenvio à questão-enigma, particularmente por intermédio dos acontecimentos que são potência de desordem e criam possíveis. Nasce, então, a possibilidade de um discurso interrogativo, aberto, em que a temporalidade, a divisão social podem ser colocadas constantemente em questão.

salientados nos seus estudos sobre Marx e Maquiavel, os quais não se desfazem desta experiência primeira vivenciada por meio da leitura etnológica.

${ }_{53}$ Ainda que haja diferenças entre esses discursos, no pensamento de Lefort eles conservam um traço comum: são compreendidos como discursos que criam a representação de uma comunidade imaginária que permanece reportada ao fora e não ao social. 
Ao pensarmos estas duas formas de sociedade, estamos lidando, então, com dois imaginários, nos quais a ordem social pode manter-se petrificada ou não. Neste último caso, na sociedade histórica, há uma complicação a mais, pois há a tentativa constante de manter oculta a questão-origem, isto é, toda vez que se procura "colocar o pensamento em contato com o instituinte" (FH, [1974] 1979b, p. 314), através de lutas sociais, do trabalho da contestação, no bojo dos acontecimentos, surge um "discurso do ocultamento" (ibid., p. 309), isto é, uma nova ideologia. Nesse sentido, o imaginário da sociedade histórica mantém uma especificidade importante: um parentesco com o imaginário da sociedade sem história por meio da ideologia. A problemática da ideologia se desenrola no entendimento de sua natureza discursiva, como "encadeamento das representações que têm por função restabelecer a dimensão da sociedade 'sem história' no seio da sociedade histórica.” (ibid., p. 313).

Assim, se algumas sociedades se abrem para a história e outras se fecham, o mais enigmático, sem dúvida, é que nas sociedades históricas há “os sinais sempre persistentes de uma resistência à mudança, de uma tendência sempre reiterada a um fechamento nos limites já conquistados" (DEP, [1987] 1999a, p. 306). Portanto, Lefort busca discutir a ideologia como discurso nascido na sociedade histórica, a fim de compreender o significado da denegação da história, do acontecimento produzido por ela. O que ela faz, nesse sentido, é interditar o reenvio constante ao enigma da instituição que permite aos homens pensarem e repensarem suas próprias práticas e representações e criarem possíveis.

Antes de nos determos, propriamente, na "obra" do discurso ideológico, apresentamos o nascimento da ideologia através de dois cenários pensados por Maquiavel e Marx, segundo a interpretação de Lefort.

\subsection{Dois cenários para o nascimento da ideologia}

A forma política de cada sociedade não se dissocia do entendimento da mise en forme das relações sociais, isto é, da forma que adquire o conflito social - se ele é reconhecido ou denegado - e, particularmente, a ideia de que esta forma está ligada ao "modo de se gerar e de se representar o poder" (ibid., p. 309), em que se constitui uma mise en scène (cena, encenação). Para que possamos compreender melhor esta ideia, 
nos reportamos ao Le travail de l'oeuvre Machiavel (1986c), a tese de doutorado escrita por Lefort sob a supervisão de Raymond Aron, iniciada entre 1954 e 1955 e concluída em $1972^{54}$. Neste estudo, encontramos a ideia de que a instituição do social é pensada sob a perspectiva da divisão social, a qual é entendida como "originária", ou seja, como engendradora de representações sobre si mesma que podem garanti-la como fonte de criatividade social, como sinônimo de possíveis, de mudança histórica ou, por outro lado, como denegação e, com isso, operar um princípio de conservação que no âmbito da sociedade moderna se denomina como ideologia.

Assim, abordaremos inicialmente alguns elementos da interpretação de Lefort da obra O Príncipe (1999) para pensarmos o significado da divisão social e do poder como fundamentos da sociedade moderna ${ }^{55}$ para depois nos concentrarmos sobre seu trabalho a respeito dos Discursos sobre a primeira década de Tito Lívio (2008) em que discutimos o cenário florentino, onde se dá o nascimento da ideologia humanista.

Construímos o segundo cenário para o nascimento da ideologia a partir dos contornos da forma de sociedade histórica que foram extraídos por Lefort da obra de Marx, cujo ponto de partida é a sociedade burguesa e sua relação com as formas précapitalistas de produção - asiático, antigo e feudal. Lefort confere grande importância a esta relação e encontra no despotismo asiático elementos para pensar a constituição do imaginário social da sociedade histórica. Estas formas de sociedade são vistas como reflexão, como mantendo uma relação de parentesco entre si e são discutidas por Lefort para ressaltar: a) a lógica de uma dissolução do corpo social na sociedade burguesa na qual a totalidade passa a ser invisível, em relação à forma comunitária das sociedades pré-capitalistas; b) o parentesco mantido pela sociedade burguesa com o despotismo asiático, em termos de uma história repetitiva, embora haja uma nova compreensão do tempo como criação, regido pelo novo; e c) o imaginário da sociedade burguesa definido pela ideologia que preenche a função de petrificação do social no lugar dos mitos e da religião.

\footnotetext{
${ }^{54}$ Este trabalho apresenta relevância fundamental no entendimento da ideologia na obra de Lefort, de modo que nos reportaremos a ela em vários momentos de nossa discussão.

${ }^{55}$ Temos aqui, portanto, o entendimento de que Maquiavel fundou uma nova compreensão sobre uma forma específica de sociedade: a sociedade moderna, pois sua unidade e sua identidade não podem ser alcançadas e toda tentativa para chegar a essa definição pela constituição de uma imagem, por uma reflexão de si mesma que está atrelada ao poder. Nessa leitura, o poder não pode ser pensado como um fato, mas sim como indissociável de sua representação, conferindo uma identidade à sociedade.
} 
Nos escritos de Marx e Maquiavel, Lefort procede a uma leitura que visa desfamiliarizar o seu leitor com as representações produzidas pelas interpretações de suas obras ${ }^{56}$. Lefort considera que à primeira vista, Maquiavel apresenta um discurso ordenado e demonstrativo, circunscrevendo o campo de sua investigação como aquele das operações empíricas que requerem a tomada do poder. Há, no entanto, na sua perspectiva, um “duplo jogo da escrita” (LTO, 1986c, p. 345), pois seu discurso é perpassado por meandros (ibid., p. 335), por desvios, contendo uma démarche sinuosa, em que o leitor é convidado a adentrar em "múltiplos planos" (ibid., p. 345), em vários pensamentos. Ao mesmo tempo, Lefort preocupa-se em compreender o que não é explicitamente dito por Maquiavel, mas que permanece no seu horizonte a comandar seus pensamentos, seu espírito e que é informulável. Da mesma forma, considera importante discernir as ironias, a troca de vozes presente no seu discurso, as palavras em falta, pois parte do pressuposto de que não há transparência na linguagem da obra (ibid., p. 50)

Assim, ele procura colocar em relevo o discurso de Maquiavel como aquele construído como crítica às ilusões de sua época. Arranjado dessa maneira, este discurso é compreendido como lenta e metódica destruição do ensinamento político tradicional (ibid., p. 399), pois ele cria um lugar de desconhecimento (ibid., p. 446), em relação ao conhecido afirmado por aquela tradição, a tal ponto que é capaz de conceber uma nova ontologia acerca do político ao divergir da perspectiva teológica. Sua linguagem, seu movimento de pensamento constituem um deciframento, um desvelamento dos discursos de sua época, sendo considerado por Lefort como um combate às ideologias (ibid., p. 445) ${ }^{57}$.

\footnotetext{
${ }^{56}$ Este é um traço marcante nos escritos de Lefort e que não poderemos desenvolver em seus pormenores aqui, mas que gostaríamos de salientar, pois nos diz muito sobre o estatuto do seu pensamento. Lefort assume uma maneira de ler as obras dos autores procurando não apenas o que é dito e afirmado por eles, mas o próprio movimento da palavra que pode conter ambiguidades, desmentidos que escapam ao controle e ao domínio daquele que escreve e, por isso mesmo, abre-se um caminho para a interpretação que não busca apontar as faltas, mas compreendê-las como aberturas, lacunas onde o pensamento também se faz. Ao mesmo tempo, Lefort não desprende sua leitura das interpretações da obra de pensamento, estando atento àquilo que é denegado na obra, justamente porque ela tende a ser recortada, fragmentada para que o intérprete possa confirmar a sua tese. Dessa maneira, algo permanece silenciado na palavra do intérprete, ou seja, ele deixa de falar sobre certas coisas para considerar outras que lhe permitem alçar ao domínio da obra, sendo considerada por Lefort uma operação ideológica, conforme veremos no último capítulo. A recusa em produzir a determinação da obra e, no mesmo instante, manter em mente as interpretações deterministas da obra constitui um traço do pensamento contraideológico de Lefort.

${ }^{57}$ É importante mantermos a ideia de que o discurso crítico de Maquiavel não se coloca como afirmação contraposta ao discurso teológico, pois se mantém como linguagem em vários planos, procurando
} 
Lefort chega a esta compreensão porque seu trabalho interpretativo é movido pelo entendimento da relação que o discurso crítico mantém com o discurso político, na medida em que este parece se modular como ideologia (cf. LTO, 1986c, p. 21). Esta questão é o laço que une Lefort a Maquiavel e que esclarece profundamente a sua própria démarche, pois ele também procurou abrir uma crítica às ilusões de sua época, não se dissociando dos discursos políticos nascidos no seu tempo presente.

Quanto à retomada do pensamento de Marx, ela implica, para Lefort, rediscutir certa compreensão de seu pensamento, a qual identifica apenas a vertente evolucionista de seu entendimento da história, apresentada como uma série de revoluções sobrevindas dos modos de produção e de troca. Para Lefort, no entanto, trata-se de encontrar o "desmentido" nos escritos de Marx, ou seja, certa ambiguidade em sua leitura da história que nos permite apreender a existência, na obra, de duas visões da história que ora se excluem, ora se combinam. Ele se refere a uma oposição, presente em Marx, entre a ideia de continuidade e descontinuidade da História, em que há duas interpretações que ora se excluem, ora se complementam: uma delas de inspiração darwinista e outra shakespeariana.

Por exemplo, fui muito cedo sensível a uma oposição entre a ideia de continuidade e a de descontinuidade da História em Marx; a ideia de um movimento inelutável regulado pelo desenvolvimento das forças produtivas, que faz passar de um modo de produção a outro e a de uma ruptura entre todos os modos de produção pré-capitalistas e o capitalismo moderno; a uma oposição entre a ideia de uma dissolução de todas as relações sociais limitadas e a ideia de uma força de conservação, de mecanismos de repetição que, até no capitalismo, asseguravam a permanência de uma estrutura. Por exemplo, fui também extremamente sensível à vacilação de uma interpretação que ora queria conhecer apenas os fundamentos materialistas da vida social e de sua evolução, ora descobria todo o peso do imaginário social, a função dos fantasmas que perseguem o presente ou a do fetichismo - interpretação de inspiração ora darwinista, ora shakespeariana. (ID, [1979a] 1983a, p. 110)

Assim, considerando o modo como Lefort interpretou estes dois pensadores, tomando como ponto de partida a representação de suas obras que estão presentes nos discursos póstumos produzidos pelos comentadores da obra, possibilitando o surgimento de ideias como maquiavelismo e maquiavélico, por um lado e, por outro, de toda a tradição marxista, vemos que ele procura liberar o pensamento de Maquiavel e de Marx das visões deterministas que acabam fechando a interpretação e, portanto, sendo

desdobrar a questão do poder, da política e, assim, abrir caminho para a interrogação. Esse é o movimento de pensamento contraideológico figurado na obra de Maquiavel e que discutiremos no quarto capítulo. 
ideológicas. Ao mesmo tempo, procura tratar suas obras como discursos críticos que, frente às ideologias de sua época, buscaram recolocar o pensamento em contato com o discurso instituinte e abrir novas perspectivas.

\subsection{A gênese da ideologia no humanismo florentino em Maquiavel}

Em $O$ Príncipe de Maquiavel, adquire centralidade o confronto entre dois desejos inconciliáveis: o desejo dos Grandes de oprimir, cuja essência é o desejo de ter, e o desejo do povo de não ser oprimido, detendo o desejo de ser. Estes dois desejos podem ser entendidos como inseparáveis um do outro, pois a origem do desejo de não opressão encontra-se no desejo adverso - no desejo dos Grandes de oprimir -, significando que o desejo apenas pode existir no modo de sua intersubjetividade, ou seja, que o desejo está fora da classe e cada desejo pressupõe o desejo do outro, como explica Poltier (1998, p. 144). Nesse sentido, o ponto de partida de Lefort em Maquiavel está no entendimento de que o conflito é algo que não deve ser eliminado, pois é fonte de vida política, estando no coração da sociedade histórica.

Encontramos, então, um elemento central: a gênese do espaço político deixa de ser buscada em uma ordem divina, natural, para enraizar-se na relação social como produto da ação humana. Nesta leitura, a divisão não é entendida em si mesma, mas em função da posição do sujeito político - o príncipe -, a qual não está no plano da natureza, mas vincula-se à soberania reconhecida como imaginária, de onde é possível desvelar todas as questões sobre o ser da política e da história (LTO, 1986c, p. 461). O fundamento da divisão social encontra-se, então, no desejo, o qual tem a propriedade de instaurar o poder como um "terceiro", ou seja, como aquele que extrai sua razão de ser e sua existência do conflito, surgindo para instituir a ordem civil, a unidade da sociedade, a sua identidade, localizando-se acima da luta entre as classes. O poder é engendrado pela divisão como um "poder separado" (ibid., p. 433) e, nesse sentido, é momento de "aparição" do poder, entendido por Lefort como "momento na instituição do social" (ibid., p. 433).

Mais importante do que apontar a existência de um domínio da política, necessariamente separado, o qual nos remete à questão da abstração, ao ponto de vista de sobrevoo, é compreender, nesta operação, que o poder se dá como reflexo, ou seja, que não se deve esquecer de onde provém o poder, de quem ele se separa: do próprio 
povo. Quando isto ocorre, o poder permanece inconsciente de sua própria origem ${ }^{58}$. Para garantir que o poder mantenha esta reflexão é preciso um trabalho de interpretação, de um reenvio ao fundamento do poder e da política:

É por conhecer a estrutura particular do campo de forças, de compreender porque elas são incomensuráveis, isto que são, em sua singularidade, o desejo dos Grandes e o desejo do povo, que o príncipe descobre o limite da objetivação e que aparece para ele mesmo como situado na Sociedade, investido de um poder, encarregado de encarnar a comunidade imaginária, esta identidade em falta da qual se dissolve o corpo social. Nesta reversão de perspectiva se realiza a verdade da separação: o príncipe aprende, com efeito, que ele só saberia sem se perder se identificando à imagem que se compõem a partir dele os dominantes e os dominados; no momento mesmo em que ele põe à prova de sua dependência, e em que ele se sabe ligado ao povo, ele impede a si mesmo de satisfazer o desejo do povo, mantendo esse desejo em suspenso, para permanecer como um terceiro, graças a quem se institui a ordem civil. (LTO, 1986c, p. 434)

Nessa perspectiva, o poder não pode ser entendido como alguma coisa empiricamente determinada (FH, [1974] 1979b, p. 302), resumindo-se a funções empíricas (DEP, [1987] 1999a, p. 310) - como detentor do monopólio da violência legítima -, pois ele é indissociável da imagem, da representação constituída pelos sujeitos sociais, significando que ele é inseparável de um imaginário, uma vez que responde à imagem construída pelos dominantes e pelos dominados, no jogo de suas articulações. A unidade e a identidade social, portanto, encontram-se na dependência da operação do desejo que cria uma imagem constituída e refletida pelo poder.

Mas há o que Lefort aponta como a "ambiguidade da política", pois na experiência da separação, onde ela adquire toda a sua significação, no momento em que o príncipe deve metamorfosear seu desejo por potência e glória no desejo de seus súditos, ele está vulnerável ao chamado "ponto cego", ou seja, o príncipe pode se deixar fascinar por sua própria imagem, por seus desejos e, assim, tornar-se estrangeiro ao povo, fechando-se nos muros de uma fortaleza. Esta alienação pode alimentar um imaginário em que o desejo do príncipe acaba por nutrir o próprio desejo do povo, fazendo com que seu próprio desejo seja o desejo dos outros. Trata-se, então, de uma

\footnotetext{
58 Ao falar em "origem", Lefort compreende a partir de Maquiavel, que não se trata de um retorno ao passado, mas sim que a instituição do social se dá no presente, em cada aqui e agora, ou seja, é aquela que não está petrificada no tempo, se fazendo e refazendo, pois cabe ao sujeito político interpretar as condições presentes, uma vez que o poder é reflexão das relações de força entre as facções e as classes (LTO, 1986c, p. 601).
} 
potência ilusória que resiste enquanto não houver hostilidade manifesta por parte do povo $^{59}$.

Esta discussão nos remete à compreensão de que há diferentes tipos de poder e diferentes tipos de imaginários, implicados como estão na interpretação da política como aquilo que é, não se desvinculando da ação. Temos, então, a ideia de uma reflexão que deve perpassar os desejos, pois o príncipe é entendido como aquele sujeito que realiza um movimento de saída e de retorno para si mesmo, colocando o seu desejo no campo da História. Sua própria imagem depende de uma defesa contra si mesmo para encontrar aquela do povo, pois há uma fundação incessante da política, pois esta não tem fundamento em si, descobrindo-se na contingência da ação, em cada aqui e agora (cf. LTO, 1986 c, p. 435)

Como afirma Flynn, em linguagem contemporânea, Lefort está descrevendo o caráter descentrado do sujeito político (FLYNN, 2005, p. 35) a partir do príncipe, pois a base do seu poder político está fora dele mesmo e sempre lhe escapa, sustentando, então, uma relação de indeterminação com o real. Nesta leitura, a subjetividade soberana é eclipsada, pois o sujeito político somente pode se estabelecer pelo jogo de forças que estão fora dele, estas se constituindo enquanto forças que falam através dele.

O príncipe é aquele que se interroga constantemente sobre os fundamentos de seu poder (cf. LTO, 1986c, p. 435), mantendo, então, uma relação de interrogação com a verdade, a qual advém sempre em cada aqui e agora da ação e, ao mesmo tempo, escapa sempre à representação. Lefort identifica, na fala de Maquiavel, que toda ação política é um risco, um talvez que anuncia os termos de um jogo indeterminado, tal como nos deixa perceber a ideia do príncipe novo: aquele que deve ganhar a adesão do povo, devendo se constituir como novo à prova dos acontecimentos.

Diz-se: é sempre em um campo social e histórico determinado - hic et nunc - que o príncipe deve conceber sua ação; em função de certos dados que ele está em condições de prever o futuro, de pesar as forças contrárias, de impor e de manter sua autoridade. Mas ele precisa se lembrar que este campo, estes dados, eles mesmos variam constantemente, que o tempo persegue [chasse] tudo diante de si e que, assim, não há conduta e métodos seguros, ao abrigo do acontecimento. (LTO, 1986c, p. 442)

\footnotetext{
${ }^{59}$ Em Lefort, o fascínio do príncipe por sua própria imagem é repensado a partir da figura do Egocrata, o qual constitui o imaginário da forma de sociedade totalitária, como podemos encontrar em seus artigos sobre a lógica totalitária (ID, [1980a] 1983a).
} 
A imagem, portanto, adquire importância central na obra de Maquiavel, não sendo vista nem como obscurecimento da realidade, nem como independente da realidade, mas tendo um papel constitutivo. Por meio da imagem do príncipe dá-se a constituição do poder político e a metamorfose segundo a qual a sociedade civil é transformada em sociedade política (cf. FLYNN, 2005, p. 6). Nesta perspectiva, está implícita a compreensão, conforme esclarece Flynn, de que o príncipe é o sujeito político constituído por meio do jogo de desejos, mascarando uma voz fundamental, uma não coincidência do corpo político (ibid., p. 10). Ele é pensador e ator, interpreta os desejos. O príncipe não é uma substância que pode ter ou não ter certas qualidades, mas seu ser é ser "reconhecido", pois sua conduta é indissociável da representação que o Outro pode formar sobre ele, como na relação governante-governado (LTO, 1986c, p. 404). O ser do príncipe, então, está fora dele mesmo, reside nas aparências, na imagem, suas ações, por sua vez, não se desprendem do trabalho de interpretação do sentido da imagem que nele está inscrita (ibid., p. 407)

Mas esta imagem não é simplesmente aquela que o povo quer projetar, pois o príncipe precisa despertar o desejo de ser amado pelo povo e não odiado. Enquanto amor e ódio se dirigem à pessoa do príncipe, respeito e temor se dirigem à posição do príncipe, a qual está acima da sociedade e dos conflitos que emergem dos desejos incompatíveis (FLYNN, 2005, p. 23)

Assim, o príncipe precisa colorir suas ações, pois sua virtude precisa manter o ar dos fundadores, isto é, sua ação precisa defletir de sua própria pessoa em torno de uma imagem. Se cair a máscara e expressar-se a si mesmo, deixando seu cinismo aparecer, ele poderá ser reduzido à sua própria pessoa, exposto ao olhar de todos, sendo mais um homem entre os demais (LTO, 1986c, p. 414). Em certa medida, o poder inclui a mistificação (ibid., p. 413) pela máscara que ele deve usar, a qual não pode ser estranha à imagem desejada pelos súditos, pois somente dessa forma o poder pode se distinguir da potência, aliando ser e aparecer. Temos, então, a compreensão de que deve haver a transcendência do poder que vai de par com a constituição de um imaginário para que o povo possa figurar sua unidade e deixe de ser simples matéria de opressão.

Nesse sentido, dizer simplesmente que o príncipe é diferente daquilo que ele é, segundo a perspectiva do teórico, é perder de vista que o imaginário não se distingue 
pura e simplesmente do real, mas que o primeiro se insere no segundo, significando que "a realidade do poder está ligada a um imaginário" (ibid., p. 416).

A imagem do príncipe é projetada acima do conflito social e acima dele mesmo. Esta imagem é defletida no sentido de constituir o lugar do poder político, o impresario. O povo deseja que ele regule o desejo dos Grandes e, ao fazer isso, ele ganha a amizade dos dominados e neles encontra apoio para sua própria conservação. Assim, o poder é indissociável de um imaginário, pois sua eficácia depende da imagem que ele desperta em seus súditos, de sua aptidão em responder àquele desejo. Quando isso deixa de ocorrer, a sociedade é apropriada pelo desejo insaciável dos Grandes, onde reinará a pura discórdia, a corrupção, interesses que se entrechocam diretamente, uma situação nomeada como licença. Nessas circunstâncias, o poder não está ausente, mas sim nas mãos dos poderosos e se exerce com vantagem sob a cobertura da divisão social denegada; é a desordem que se acomoda bem em Florença, da aparência da ordem, do equilíbrio adquirido das forças sociais. O poder é visto, então, aos olhos do povo como instrumento detido pelas classes dominantes, como puramente opressor, constituído apenas como força, não sendo reconhecido pelos dominados como aquele poder encarnando a generalidade do social, além do conflito de classe (cf. POLTIER, 1998, p. 138).

Somente o desejo do povo - o desejo de não ser oprimido - pode ser a origem da lei e da liberdade. Somente o povo sustenta a imposição de limites à opressão, pois ele é o único a querê-la. A lei, então, é a instituição de direito da resistência do povo à opressão, ela é conforme ao ser da sociedade, ou seja, ela é oriunda da divisão social. O Tribunato da Plebe em Roma, então, adquire todo este sentido, pois nele reside a lei como instância anônima, a condição para colocar um freio à insolência dos Grandes (LTO, 1986c, p. 473), ele é órgão da negatividade (ibid., p. 476) ${ }^{60}$.

\footnotetext{
${ }^{60}$ À partir deste parágrafo, referimo-nos à leitura de Lefort dos "Discursos sobre a primeira década de Tito Lívio"(2008). É importante demarcar esta passagem, pois em sua interpretação, a relação entre esta obra e O Príncipe é de continuidade, pois ambas abordam a questão da forma das relações sociais, por meio da divisão grandes-povo. No Príncipe, o discurso de Maquiavel se volta para a constituição do campo da política a partir de um ponto determinado do poder, referindo-se à divisão do Estado e da sociedade civil, à divisão das classes e do desejo de classe, do presente e do passado, em função da posição de um Sujeito político - o príncipe - tendo em vista a questão da dominação política. Nesse sentido, a sorte da divisão se decide em função do modo de divisão do poder e da sociedade civil, determinando uma forma de sociedade. No que diz respeito aos Discursos, essa questão se mantém, sendo articulada a uma interrogação sobre Roma e sua representação, mantida pelos florentinos de seu tempo. Dessa maneira, na interpretação de Lefort, o entendimento de uma forma de sociedade passa pela questão da divisão social, mas também pela relação que uma sociedade mantém com a representação do passado,
} 
Nesse sentido, negar a divisão social é o mesmo que reprimir o desejo do povo e refutar a lei, enquanto estabelecer o direito do povo é afirmar seu direito de não ser oprimido, reconhecendo que a divisão é constitutiva da sociedade. O regime da liberdade é aquele no qual a lei tem lugar de poder, onde há o reconhecimento da divisão e, assim, da legitimidade da resistência do povo ao desejo de dominação dos Grandes. Uma sociedade pode ser livre quando coloca como princípio de suas instituições o desejo do povo de não ser oprimido. Isto explica a primazia pela República.

Devemos considerar que o desejo do povo é negatividade pura, isto é, não tem objeto determinado, sendo potência de contestação de todas as figuras estabelecidas e, particularmente, da própria figura que vem a ser constituída pela sociedade para si mesma. Neste sentido, sempre que o poder se encontre fundamentado sobre o desejo do povo, então, ele libera a potência de indeterminação que está na sociedade e, assim, a criatividade histórica. Se isto não ocorrer, tem-se a decadência do poder, ou seja, sua submissão aos interesses da classe dominante, a obliteração da relação com a lei.

Compreendemos, desse modo, que a maneira segundo a qual o poder se reporta ao conflito social é de importância fundamental, pois ele pode reconhecer o conflito ou não. A denegação do conflito constitui, então, a imagem de uma sociedade unificada, em harmonia, em concórdia social, em que o poder mascara seu conluio com a classe dominante e cria a imagem de um poder a serviço do bem comum. Trata-se da imagem da boa sociedade, cujo elogio da união carrega consigo "o desconhecimento da divisão de classes", seu mascaramento que implica na destruição da liberdade (LTO, 1986c, p. 475).

A grandeza de Roma, por exemplo, encontra-se atrelada aos seus tumultos, à desunião entre a Plebe e o Senado, responsáveis por gerar boas leis, constituindo-se como fundamento da liberdade. Nesse sentido, salienta Lefort, Maquiavel inverte a tese

pela imitação, bem como pelo discurso, produzido pela ideologia, tendo por função impedir que as tarefas do presente sejam afrontadas. É por isso que esta segunda obra nos interessa particularmente, porque nela Lefort discute a questão do acesso ao real, aqui e agora, como proveniente de um cruzamento entre política, história e discurso teórico - os escritos de Tito Lívio na obra de Maquiavel - que ocorre por meio da interrogação. Nesse processo, a ideologia é fundamental porque ela pode constituir um mecanismo de imitação, garantindo que o passado esteja no presente, apagando a diferença temporal e, ainda, sabendo que ela é da ordem do saber, encontra-se nutrida por fundamentações teóricas para aplacar os acontecimentos. Quanto ao discurso de Maquiavel, ele é concebido, por Lefort, nos Discursos, como aquele que se torna capaz de realizar uma "desmistificação" (LTO, 1986c, p. 466), permanecendo vinculado "à representação de Roma" (ibid., p. 756). 
tradicional, calcada na interpretação de que as boas leis derivavam de sua eficácia em conter os desejos da multidão (DEP, [1992d] 1999a, p. 144). Esta inversão, por sua vez, contém uma interpretação que ultrapassa o próprio tempo - a história de Roma - e nos remete ao fundamento do Estado moderno, pois todas as leis favoráveis à liberdade nascem da divisão dos humores do corpo político (LTO, 1986c, p. 476).

Um elemento importante destacado por Lefort é a ideia de que a ordem e a desordem são inseparáveis, ou seja, que a ordem não pode ser estabelecida sobre a eliminação da desordem, pois isto significa uma degradação da lei e da liberdade. É importante salientar que a desordem não pode ser pensada como "pura discórdia" em que se entrechocam interesses particulares, mas sim como a "operação do desejo" que abre a questão sobre a unidade do Estado, desvelando-a e constrangendo aqueles que o dirigem a recolocarem em jogo o destino da sociedade (ibid., p. 477). No mesmo sentido, não se trata de conceber um legislador à distância do conflito para que opere a sua regulação, uma posição equivalente àquela do teórico, pois a divisão de humores é constitutiva da forma de sociedade histórica, da vida política.

A todo o momento, Lefort encontra elementos na fala de Maquiavel, onde o autor procura evidenciar que a grandeza de Roma ${ }^{61}$ está em sua capacidade para responder aos acontecimentos, pois ela é feita de uma classe dominante cega por seu egoísmo e o povo por suas ilusões e pela credulidade, que ela é perpassada por acidentes como a república mais decadente. O elogio desta forma de sociedade, então, não se desprende dos desafios enfrentados por ela, pois ela não deixa de ter sempre no seu horizonte a corrupção e que a passagem para uma ditadura, por exemplo, depende de uma solução ao problema da "economia interna do poder" (LTO, 1986c, p. 511), isto é, do jogo dos desejos. Nesse sentido, toda forma de sociedade mantém sempre em perspectiva seu possível outro, ou seja, uma forma que se constitui pela denegação do conflito, como a república e a tirania, em Maquiavel, e como democracia e totalitarismo em Lefort, e que está contida no seu íntimo e também cristalizada em outros sistemas

\footnotetext{
${ }^{61}$ Ao falar de Roma, Lefort considera que Maquiavel quer falar de Florença, pois procura examinar as instituições, as guerras que enfrentou, o papel dos grandes homens justamente para poder discutir o que Florença pode aprender com Roma, esta sociedade histórica. De acordo com esta visão, em Roma se lê a "dimensão propriamente histórica de toda sociedade" (LTO, 1986c, p. 585) e da sociedade da época de Maquiavel. Nesse ponto, a grandeza de Roma está nos conflitos de classe e na guerra, ela coloca constantemente em jogo o adquirido que se articula com uma mudança interior, uma diferenciação, a expressão e a oposição de classes que a constrangem a inventar novas instituições, a ligar a exigência de sua conservação àquela de uma criação histórica (ibid., p. 588-589). Esta sociedade fornece o quadro de inteligibilidade de todos os outros esquemas de desenvolvimento, segundo a interpretação de Lefort.
} 
políticos. Portanto, o outro não pode ser entendido somente como algo externo, mas como possibilidade permanente, como germe (ibid., p. 518), de modo que qualquer forma de sociedade é algo que se "conquista constantemente contra outros possíveis" (FH, [1970a] 1979b, p. 162).

Suas instituições, como ele sugere [Maquiavel], não são intrinsecamente boas, tampouco seus cidadãos virtuosos (muitos exemplos nos são dados a respeito da ambição de alguns deles, até mesmo de suas empreitadas conspiratórias); a história romana fornece a imagem de uma Cidade que, em vez de se fechar em si mesma, acolhe o conflito e inventa, submetendo-se à experiência dos conflitos e dos tumultos, "respostas" que permitem pôr em xeque a constante ameaça de tirania e, ao mesmo tempo, a constante ameaça da licenciosidade. (DEP, [1992d] 1999a, p. 145)

A natureza do regime não se define, então, pelas intenções do príncipe, nem pela forma das instituições, mas sim pela relação que o Estado estabelece com o conjunto dos sujeitos ou dos cidadãos e, particularmente, no que diz respeito ao jogo dos desejos. As formas de sociedade (Florença, Roma, Esparta) podem ser entendidas como "respostas diferentes" (LTO, 1986c, p. 486) a um único problema - a questão da divisão -, comandando um esquema específico de desenvolvimento. Dessa maneira, Lefort aponta em Maquiavel que a república romana e a república florentina encontramse sob a mesma condição, ou seja, afrontam as mesmas dificuldades, elas vivem "a mesma história" (ibid., p. 515) que atravessa todas as sociedades.

A fala de Maquiavel, então, pode ser entendida como aquela que quer abalar as representações de sua época, fundadas no elogio da república romana, pela bela imagem de sua união que se dá no desconhecimento da divisão das classes. Na leitura de Lefort, a representação de Roma exerce um papel importante, pois o amor dos florentinos por ela serve, na verdade, para recobrir sua impotência em lidar com as tarefas do momento (cf. LTO, 1986c, p. 465-466). O comentário de Maquiavel aos dez livros de Tito Lívio é entendido como uma transformação da representação de Roma como ela existiu na Florença de seu tempo, a qual se caracterizava pela idealização da Antiguidade e, particularmente, pela idealização de Roma (DEP, [1992d] 1999a, p. 149).

Maquiavel introduz uma interpretação de Roma que a recoloca com uma concepção completamente histórica em que o conflito de classes exerce um papel fundamental, justamente porque, em seu tempo, havia uma ideologia conservadora responsável por criar outra imagem de Roma, utilizada pela alta classe florentina que 
tem prazer na representação humanista de Roma. Nesta representação, concebida pelos autores clássicos e também pela moral religiosa, Maquiavel procura colocar em questão a "reconstrução imaginária", apresentando tudo o que Tito Lívio, Plutarco e a maior parte dos historiadores procuraram silenciar: o discurso dos dominados, sempre perigoso, o discurso do Outro. Os temas do discurso que perpassava a Florença do tempo de Maquiavel são destacados de maneira resumida por Lefort:

[...] a concórdia entre os cidadãos (unione) e o perigo das dissensões, sempre imputadas às facções; a bondade intrínseca às instituições primevas e o perigo das mutações; a defesa do status quo na Itália; e também a virtude do justo meio, e as virtudes do menor risco e da contemporização. (DEP, [1992d] 1999a, p. 149, grifos do autor)

Lefort identifica, na obra de Maquiavel, um discurso que procura denunciar as ilusões pelo trabalho de destruição e de conservação do discurso antigo, o que dá nascimento à possibilidade de um conhecimento da história (cf. LTO, 1986c, p. 544).

O prazer que dão a si mesmos, dos exemplos e máximas que são a combinação de um prazer estético e uma exaltação moral, mascara um conhecimento defeituoso (cf. LTO, 1986c, p. 534). Assim, Roma tornou-se um ideal fora do tempo e da história - um mito - nas mãos da burguesia florentina, uma idealização que contribui para que Florença seja incapaz de dar nascimento à ação. Esta idealização do passado, por sua vez, não é fortuita, mas a tentativa de evitar os problemas do aqui e agora, deslocando a interpretação que exige o presente pela "ilusão do bom passado" (ibid., p. 536), em que o florentino é identificado ao romano de outrora.

Esta identificação, tomada por Lefort no sentido forte, pois não se trata de imitação, nem de uma interpretação da história romana ${ }^{62}$, mas, sim, que os florentinos se veem como romanos, comportam-se "segundo a imagem dos romanos: pretendem ser seus descendentes, afirmam que o sangue romano corre em suas veias" (DEP, [1992d] 1999a, p. 150). Esta imagem é construída sobre o discurso humanista republicano, transmutando a natureza da República Romana, desdobrando um discurso sobre a

\footnotetext{
${ }^{62}$ Neste trabalho está em movimento a diferença entre a interpretação e a identificação. Enquanto a primeira consiste em uma abertura para o pensamento crítico, a segunda leva à ideologia, pelo fato de contribuir para a definição, a determinação da identidade de uma sociedade, pelo recurso a mitos do passado, figuras emblemáticas, com o intuito de ressignificar acontecimentos para desmantelar o trabalho de interrogação que se faz no presente. Mas é importante assinalar que a interpretação é um jogo que procura desvelar o trabalho realizado pela produção de identificações por parte da ideologia, conforme veremos no quinto capítulo.
} 
história e sobre a sociedade, criando uma representação do humanismo. Trata-se de uma fantasmagoria da humanidade, da história, da cidade que reverencia a imagem de uma classe dominante.

Em Florença, instaura-se uma representação nova da História e da missão da Cidade, de sua origem, de seu regime e de sua missão que faz do humanismo uma obra ambígua, pois, ao mesmo tempo em que este discurso é responsável pela difusão dos princípios republicanos na Europa, em Florença especificamente, o elogio humanista da República Romana adquire uma particularidade, pois, na conjuntura na qual se forma, mantém uma contradição fundamental: está dilacerado "entre a reivindicação de verdades universais e a justificação do estado de fato" (FH, [1973] 1979b, p. 252-253). Isso significa que, na conjuntura marcada pela insurreição dos Ciompi (operários da lã) ${ }^{63}$, entendida como ameaça inesperada ao poder da classe dirigente, o discurso que se apoia em uma ética política - no humanismo cívico - está, na verdade, recobrindo as questões abertas por aqueles que se lançaram em reivindicações democráticas, em lutas pela extensão dos direitos do, então, considerado populacho.

Portanto, o discurso revela-se como mentira, pois, como nos indica Lefort,

[...] a ideia de virtude que encontra sua razão de ser e sua recompensa nos limites da vida terrestre acomoda-se a uma ordem social em que a religião cristã preserva todo o seu poder, porque esta proporciona a vantagem de manter o povo em obediência, persuadindo-o de que "é mau falar mal do mal". Segunda mentira: a ideia de superioridade da vida ativa dissimula a cisão, advinda e mantida em Florença, entre o burguês e o cidadão, cisão que revela, antes de mais nada, a prática que consiste em apagar os exércitos estrangeiros ou mercenários para assegurar a defesa da Cidade. Terceira mentira: a ideia de um exercício coletivo dos cargos públicos mascara a monopolização do poder por uma oligarquia. Uma minoria apresenta-se como guardiã das instituições livres, ao passo que confunde a conservação destas com a conservação de suas prerrogativas. (DEP, [1992d] 1999a, p. 154)

Assim, certas "verdades universais", retiradas do humanismo, são empregadas para justificar uma ordem social em Florença e não para marcar o despontar da democracia. Há a dissociação de um sentido manifesto, de um sentido latente do discurso, levando-nos a considerar que a criação de uma representação sobre o humanismo, então, tem o efeito de anular a possibilidade de uma nova ordem social em Florença.

\footnotetext{
${ }^{63}$ Revolta popular ocorrida em Florença, em meados do século XIV, contra a aristocracia dominante e comentada por Maquiavel.
} 
Por fim, chegamos à questão do surgimento da ideologia pela representação do humanismo. Para que possamos compreender plenamente esta proposição de Lefort, devemos ter em mente que a gênese está vinculada ao cenário de Florença, onde ocorreu o desdobramento de um discurso primeiro, que é o discurso humanista, em um discurso segundo - a representação deste discurso, deslocado no tempo e no espaço, pois o passado é idealizado e o discurso se verga sobre outra configuração social, constituindo uma fantasmagoria. Nesse sentido, enquanto o primeiro podia ser entendido como instituinte, ou seja, como aquele que realizou uma quebra com a ideia de que a ordem social seria regida por uma autoridade externa - teológica -, compondo, então, uma "nova imagem da relação social", regida pela ideia de que "o mundo é o único teatro da aventura humana", isto é, uma experiência da realidade concebida a partir do próprio homem, abrindo a possibilidade de discursos sobre a história, a natureza, a língua, o espaço, sobre o Eu, de um modo geral; já no segundo, estes referenciais estão separados, sobrevoando o conflito de classes e pretendendo determinar sua natureza.

Seria oportuno perguntar por que o discurso humanista - discurso da história, da humanitas - é aquele que favorece uma representação de si mesmo, um desdobramento? Trata-se de um discurso que está inscrito na história, que se abre para ela, estabelece uma visão do real a partir do próprio real e não sob o ponto de vista externo ao social, proveniente de potências invisíveis - Deus, deuses. Nesse sentido, temos a abertura para o nascimento da ideologia. O que teria advindo, então, é um discurso sobre a política, buscando visar o real a partir do lugar próprio da política. Quando a ordem social passou a ser inteiramente pensada a partir de si mesma e não mais remetida a uma ordem externa, surgiu um pensamento da política que se desdobra em pensamento sobre a política. Isto significa que a ideologia nasce quando surge o discurso do real, da política enquanto tal.

A ideologia deve ser pensada, então, no registro da metapolítica (LTO, 1986c, p. 556), pois a dissimulação da diferença temporal, da divisão interna e externa não pode ser pensada como uma conduta de fato, mas é constitutiva da sociedade onde uma nova ordem se configurou pela quebra com a ordem transcendente. Ela é originária, assim como a divisão social, pois a divisão contém em si mesma a possibilidade de seu recobrimento, enquanto discurso instituinte - da criação, dos possíveis históricos -, pois desdobra-se em discurso instituído - denegando todos os referenciais simbólicos da criação. A divisão, por sua vez, pode ser pensada como "brecha” (LTO, 1986c, p. 556), 
como "fenda" (ibid., p. 313) que acaba sempre sendo entulhada a serviço do desejo de dominação presente na sociedade que assume diferentes figuras ao longo do tempo: a burguesia, o partido no regime totalitário ou a dominação invisível nas democracias instituídas como sistemas políticos, conforme discutiremos. Isso significa que, embora a ideologia seja do registro da metapolítica, ela não se dissocia da política, pois depende das tentativas produzidas para colmatar a brecha, o discurso instituinte que nasce e renasce sempre nas lutas sociais, no trabalho de contestação e de crítica às ideologias nascentes em cada tempo no âmbito da sociedade histórica.

Todo este entendimento, Lefort deve a Maquiavel, pois considera que ele realizou uma interpretação dos discursos de sua época, objetivando a liberar a verdade da sociedade histórica romana das representações produzidas pelo discurso de dirigentes florentinos - nas proclamações, cartas e obras do humanista Coluccio Salutati, por exemplo -, procurando desfazer a boa imagem construída daquela forma de sociedade.

Em razão de dificuldades encontradas na compreensão do Príncipe e dos Discorsi, pareceu-nos que a interrogação da história e da política achava-se ligada à crítica das ideias dominantes do tempo e que estas revelavam, em seu núcleo, o pensamento político dos humanistas, formado um século antes. Pareceu-nos em particular que tudo aquilo que Maquiavel diz sobre a divisão das classes, da divisão do Estado e da sociedade civil, da diferença dos tempos - da qual a Roma antiga e a Florença moderna figuravam os termos privilegiados -, testemunhava sobre a derrocada de um discurso historicamente determinado, que se mostrava organizado de maneira a denegar o fato irredutível da divisão social e da divisão temporal, em prodigalizar a segurança de um ponto de vista sobrevoante e em apagar os vestígios das condições de sua formação. Se nos acreditamos capazes de buscar no humanismo político os sinais de um nascimento da ideologia é, pois, porque nos é revelado por uma interpretação antiga ocupada em liberar a verdade da política e da história de uma representação instituída, em tornar sensível sua elaboração em condições sociais e sua função de dissimulação. Não teríamos podido reparar os sinais da ideologia se a interpretação maquiaveliana não nos intimasse a reconhecer, no exato momento em que suscita em nós uma reflexão sobre a política e sobre a história em geral, discursos coletivos singulares, localizados, datados, de onde é extraída, feitos para recobrir as questões que reconduz à ordem do dia. (FH, [1973] 1979b, p. 255)

Portanto, no cenário político pensado por Maquiavel, temos a interpretação de Lefort sobre o nascimento da ideologia. A seguir, veremos como ele pensou a questão da gênese na perspectiva de Marx. 


\subsection{A gênese da ideologia na sociedade burguesa em Marx}

Iniciamos esta discussão pela retomada por parte de Lefort dos estudos voltados para o entendimento das sociedades pré-capitalistas de caráter comunitário nas obras Grundisse (2011) e n'O Capital (2008) de Karl Marx. O ponto de partida é o fenômeno da comunidade tribal - forma cujas modificações engendrarão os modos de produção asiático, antigo e feudal. É importante assinalar que, em tais sociedades, o esquema de propriedade está calcado na forma comunitária, segundo a qual os homens não se distinguem do meio onde exercem sua atividade, pois estão ligados à terra, fazem dela sua atividade, seu meio de subsistência, sua residência, de tal forma que somente assim podem agir como pastores e cultivadores, significando que ela não é exterior a eles. Eles são trabalhadores, mas sem que possuam tal estatuto, pois não detêm esta determinação real que apenas adquirirão no capitalismo, de modo que cada indivíduo pode afirmar-se como proprietário ou possuidor apenas enquanto membro da comunidade.

Dessa maneira, da mesma forma que o homem se acha imerso na terra, ele também o está na comuna. É por meio da comuna que estabelece sua relação com a terra, uma vez que esta medeia seu comportamento em relação a ela. Nestas condições, a forma comunitária pode ser compreendida como uma forma originária, ou seja, ela é ao mesmo tempo forma natural e forma de representação, segundo a qual os homens não são o produto do trabalho, pois esta relação aparece como natural ou divina em forma de representação e, ao mesmo tempo, a comunidade aparece a estes homens tal como é, ou seja, como comunidade do sangue, dos costumes, da língua, etc.

Embora as formações sociais de tipo despótico asiático e feudal apresentem diferentes configurações no arranjo de suas relações sociais, elas conservam o mesmo esquema de propriedade ligado à forma comunitária. Esta forma mantém-se fixa, a despeito de vicissitudes como guerras e migrações, mantendo-se, então, uma unidade interna, a unidade Homem-Terra, sejam quais forem as metamorfoses ocorridas. Assim, segundo Lefort, os fatores de mudança não podem fazer com que os homens "se percebam destacados da terra e desligados uns dos outros" (FH, [1965] 1979b, p. 223), mesmo quando se opõem como senhor-escravo, patrício-plebeu, barão-servo, mestreaprendiz, em todas estas figuras da divisão social. As relações sociais de oposição 
estabelecidas no pré-capitalismo não põem em causa, até o advento do Capitalismo, a unidade do Homem com a Terra instituída pela forma comunitária, independente das metamorfoses sofridas (cf. FH, [1965] 1979b, p. 222). Isso ocorre porque o indivíduo forma um só corpo com sua comuna e as relações sociais também tomam a forma de uma corporeidade. Na leitura de Lefort, o que Marx observa, ao refletir sobre o caráter comunitário, é a imagem do corpo, pois

Entre o indivíduo, a comunidade, a terra, como residência, como material ou como reservatório de instrumento, há um jogo de incorporações recíprocas - seja qual for o grau de diferenciação dos indivíduos (estes se determinam, por exemplo, como proprietários privados independentes) ou o grau de diferenciação comunitária (uma comunidade erigindo-se, por exemplo, acima de uma multiplicidade de outras e se afirmando no princípio da vida social). E esta imagem parece tão resistente às modificações de estrutura que o enigma da história vem se concentrar no momento de sua decomposição. (FH, [1965] 1979b, p. 223-FH)

A comuna pode ser entendida como um organismo total, cujos membros e atividades estão rigorosamente ligados. Com relação à metáfora do corpo, na sociedade capitalista, Lefort retoma as análises de Marx sobre a manufatura e sobre o processo de reificação, discutido n'O Capital. No primeiro cenário, Lefort aponta que a manufatura, ainda que nova, fundada sobre a divisão do trabalho e contendo o princípio de uma revolução continuada, mantém a representação do organismo de produção à maneira dos corpos de ofício. Assim, ainda que haja um novo modo de trabalho individual, ela não se libera do "fantasma do corpo" (FH, [1965] 1979b, p. 229). Com relação à grande indústria, em que se processa a reificação, em virtude do rompimento com a realidade e a representação comunitárias que fundavam o processo de socialização no précapitalismo, Lefort aponta que a metáfora do autômato faz eco à do corpo. $\mathrm{O}$ autor destaca uma citação da obra de Marx sobre essa ideia:

Marx fala certa vez do "monstro mecânico que, com seu gigantesco conjunto de membros, ocupa edifícios inteiros: sua força demoníaca, dissimulada primeiro pelo movimento cadenciado e quase solene de seus enormes membros, explode na dança febril e vertiginosa de seus órgãos de operação" (p. 924). Uma outra vez toma de Ure a metáfora do autômato para corrigi-la em sua aplicação ao capitalismo. "O autômato é que é o sujeito e os trabalhadores são simplesmente acrescentados enquanto órgãos conscientes a seus órgãos inconscientes e, com eles subordinados à força motriz central” (p. 952). (FH, [1965] 1979b, p. 230)

No capitalismo, o trabalhador não faz mais corpo com os meios de trabalho, ao mesmo tempo em que está dissolvido no estabelecimento de um trabalhador coletivo. $\mathrm{O}$ 
trabalhador também não faz mais corpo consigo mesmo, porque é "esfacelado e metamorfoseado em motor automático de uma operação exclusiva: o homem como fragmento de seu próprio corpo" (ibid., p. 228). Este é o momento também em que o presente não faz mais corpo com o passado, ou seja, em que se operou uma distinção no plano dos tempos históricos.

Lefort assinala, a partir de Marx, esses processos de decomposição do corpo comunitário, ao mesmo tempo em que há o eco de um corpo - no caso da metáfora do autômato - e o "fantasma do corpo", cuja consequência aponta sempre no sentido da busca, na sociedade capitalista, pela restauração de uma estrutura fixa, unitária. Em consequência, dá-se o advento de uma sociedade sem corpo, isto é, de uma sociedade privada de substância, contribuindo para a entrada em cena de fantasmas que surgem da própria sociedade, da história que têm o efeito de propiciar aquela substância, pois esta sociedade deve enfrentar, a todo o momento, a questão da sua identidade e o problema da sua unidade, levando a recorrer ao passado, aos mitos, às ilusões, enfim, às ideologias, que vêm a ser discursos responsáveis por simular a unidade que permanece em falta. Sobre esta questão, torna-se fundamental nos aprofundarmos por um momento na discussão que faz Lefort sobre uma forma pré-capitalista específica: o despotismo asiático.

O despotismo asiático constitui uma forma pré-capitalista central para Lefort, em sua reflexão sobre a ideologia, pois no despotismo asiático, há o esquema de uma história repetitiva e não de uma história evolutiva, como disposto nas análises de Marx sobre a luta de classes. Ao mesmo tempo, partindo de Marx, procura definir os elementos que compõem o imaginário da sociedade histórica em relação aos da sociedade pré-capitalista que se agencia contra a história. Ele irá perceber, na lógica deste imaginário social, a existência de certas continuidades a que a ideologia dará expressão no âmbito do imaginário da sociedade histórica.

No despotismo asiático, a corporeidade da relação social não é destruída pela formação do Estado despótico. A comunidade da aldeia desdobra-se, imprime-se em uma comunidade superior, global, encarnada no déspota, isto é, em uma comunidade imaginária, a qual reina sobre os indivíduos ou grupos separados e lhes impõe normas de conduta, de modo que a relação social é selada por uma representação que marca nela mesma o lugar de um poder. Isto significa que o poder do príncipe no despotismo 
asiático, o seu poder real, é tomado em uma representação que, ao mesmo tempo, reflete e encobre a divisão social (cf. FH, [1974] 1979b, p. 305) ${ }^{64}$. Assim, nos Estados despóticos,

[...] o príncipe se encontra inserido nas potências instauradoras ou reguladoras da ordem do mundo - porque num tal modelo não há, propriamente falando, ordem social distinta, autônoma, visível, as hierarquias humanas parecem inscritas num universo natural [...]. (HT, [1976c] 1976b, p. 194)

Um traço peculiar é o fato de que esta sociedade mantém inalterada sua organização social de base, pois ainda que ocorram mudanças violentas em suas dinastias, há conservação de uma estrutura social - do modelo comunal - a despeito das vicissitudes do Estado. Na análise de Marx sobre o despotismo, Lefort considera que ele vê, neste modelo, um princípio de estabilidade que resiste ao choque do acontecimento, principalmente das tormentas da região política, como é o caso das mudanças de dinastia. Dessa maneira, não há como permanecer em uma subordinação da representação em relação à produção, como Marx se obstina em fazer, porque, no despotismo asiático, há uma sociedade em que o modo de produção permanece essencialmente conservador, em que a divisão do trabalho e as relações sociais tendem a se cristalizar e a resistir aos fatores de mudança, em virtude da eficácia do dispositivo simbólico (cf. FH, [1974] 1979b, p. 310). É ele que assegura as condições de ocultamento, pois ele é de tal natureza que não há uma relação de oposição entre o imaginário e o real, de modo que o real vem a ser determinado por meio de uma palavra mítica e religiosa, cujo fundamento não pode ser colocado em questão (ibid., 309).

O despotismo asiático vem a ser um caso limite, considera Lefort, mas que permite decifrar os sinais de um mecanismo de autoconservação, em que se processa uma história regida pela repetição. Nesse sentido, registra-se que Marx compreendeu a noção de um tempo histórico endógeno, no qual há uma reprodução das relações sociais, cuja forma se mantém frente a um tempo exógeno, em que se dá o surgimento de novos acontecimentos que podem desfazer tudo o que fora estabelecido. As sociedades asiáticas, portanto, mostram "secretar sua própria história" (FH, [1978b] 1979b, p. 225). Elas mantêm um modo de existência em que há preservação em relação

\footnotetext{
${ }^{64}$ Esta leitura de Lefort sobre o despotismo asiático, em que destaca o papel do déspota, também será feita em seus estudos posteriores sobre o significado do Estado monárquico, no qual o príncipe também reenvia à sociedade a imagem de uma unidade, de uma realidade social que se dá como corpo. Tal estudo será fundamental em seu entendimento sobre a democracia que discutiremos no quarto capítulo.
} 
aos golpes e às tormentas provenientes da região política, assim como os que vêm de fora, tais como as guerras.

Portanto, é significativo, para Lefort, evidenciar a representação da sociedade burguesa, tal como esboçada por Marx, visto que ela não apenas opera uma dissolução de todas as formas tradicionais de produção e de representação inerentes à forma comunitária - liberando-se em relação ao domínio do passado, instaurando uma revolução continuada do modo de produção e de suas instituições - como também dissimula a si mesma sua própria história ou, melhor, a ela se furta, levando a recorrer a modelos do passado, deixando-se enfeitiçar pelos espíritos dos mortos.

Neste ponto, Lefort retoma a leitura de Marx sobre o universo da sociedade burguesa, o qual considera que está calcado em dois tipos de desenvolvimento histórico: o descrito no Manifesto Comunista (MARX e ENGELS, 2010), em que se dá um ritmo inteiramente novo, no seio desta formação social, pois ela é o teatro de uma revolução incessante de seu modo de produção, nascido da eclosão da indústria e do comércio, em que há um abalo contínuo de todas as suas instituições e na qual o passado não resiste frente aos choques produzidos pelo novo. Simultaneamente, como descrito na obra Dezoito Brumário de Luiz Bonaparte (MARX, 1978), ela é também aquela em que, no mesmo instante em que os homens estão implicados em um devir criador, que se colocam na condição de se transformarem, a si mesmos e às coisas, em criarem algo novo, em anunciarem possíveis em épocas revolucionárias, é que instauram uma história cujos conflitos não produzem acontecimentos, tendem a evocar os espíritos do passado, como os heróis romanos para os burgueses da Revolução Francesa ou os heróis do século XVIII para os burgueses de 1848.

Por que há este disfarce do presente em passado a serviço de uma história "sem acontecimentos", repetitiva ou, até mesmo, regressiva? No caso em questão, ao retomarmos o significado do poder bonapartista, é que compreendemos a natureza da sociedade burguesa e, mais amplamente, da sociedade moderna para Lefort. Ele vem a ser um produto imaginário, produto de mitos conjugados, porque se instaura em uma sociedade que a eles recorre para não enfrentar o problema de sua unidade, de sua identidade a não ser no modo da ilusão.

É nesse sentido que devemos compreender o dilema da sociedade moderna: aquela em que se coloca o problema da unidade e da identidade. No pré-capitalismo esta 
questão era respondida pela referência a um discurso mítico, religioso, de caráter transcendente, no qual não havia uma separação entre real e imaginário e, ao mesmo tempo, o social era remetido a potências invisíveis - míticas - provenientes de fora da sociedade, a fornecer a lógica de seu ordenamento. Temos, então, um modo de instituição do social em que os efeitos da divisão social e da historicidade podem ser neutralizados sob o signo da representação. Neste tipo de sociedade, a ideologia não pode surgir, porque o discurso que rege as relações sociais retira toda a sua legitimidade de uma ordem transcendente e não deixa lugar para a noção de uma realidade em si inteligível. Como resume Salinas Fortes,

Para o discurso pré-capitalista que parte da representação de uma Transcendência como instância produtora do real, o social não existe enquanto tal e pertence à ordem do epifenômeno. Sua configuração como objeto específico do saber supõe uma mutação no regime do imaginário social graças à qual se determina a ambição de dar conta do social exclusivamente a partir de si mesmo. (SALINAS FORTES, 1979, p. 9)

Na sociedade histórica, a unidade e a identidade reclamam um novo discurso que, agora, vem a ser um discurso inteiramente social, inscrito na divisão social, no seu movimento de descrição do espaço social. Nesta sociedade, o real passa a ser nomeado como tal, isto é, articulado pela fala humana, tornando-se legível porque se inaugura um modo do discurso no qual as oposições sociais se revelam, podendo ser reenviadas umas às outras, uma vez que o pensamento e a ação dos homens não estão mais regidos por um discurso transcendente - anterior e exterior à sua práxis.

É importante frisar que, no despotismo asiático, o real não é visado, justamente porque não se destaca do imaginário - não é possível divisá-lo como tal, pois é através da representação de uma transcendência que se dá a sua constituição ${ }^{65}$. Da mesma forma, o social não existe enquanto tal. $O$ efeito da representação produz uma dissimulação da divisão social, capaz de travar seus efeitos, de petrificá-la; e a dissimulação do histórico, com o poder de barrar a via da mudança ou de conter seu curso (FH, [1974] 1979b, p. 311). Nesse tipo de sociedade, haveria a representação de uma comunidade imaginária sob cuja capa as distinções "reais" se determinariam como "naturais", o particular se disfarçaria sob os traços do universal, o histórico se apagaria

\footnotetext{
${ }^{65}$ Aqui, portanto, não se trata de estabelecer o saber - religioso, mitológico - numa superestrutura, mesmo porque, trata-se de um tipo de sociedade onde o saber, a dimensão discursiva não são vistos como produtos puramente humanos e, portanto, tomados como simples ficções humanas. Verificamos, portanto, que o saber sobre a sociedade, sobre a natureza não reside, não se extrai da própria comunidade, de dentro dela, mas sim, de uma ordem transcendente.
} 
sob a a-temporalidade da essência. Assim, o espaço social só passaria a ser visível se a comunidade imaginária deixasse de existir por um momento, mudança que acena para uma alteração na "racionalidade do real" (FH, [1974] 1979b, p. 313), fazendo aparecer a (terrível) condição de uma sociedade dividida e indeterminável ${ }^{66}$, aquela que não é mais determinada por uma palavra mítica ou religiosa, abrindo caminho para o que Chauí denomina como "desejo metafísico de identidade" e para o "temor metafísico da desagregação" (CHAUÍ, [1977] 2011, p. 38).

Uma mutação no regime do imaginário faz com que o real passe a denunciar a impossibilidade do encobrimento. Ele se destaca na medida em que o poder é referido à ação dos homens e deslocado com relação à lei. Após o momento em que o poder se privou de uma garantia transcendente, ele aparece na sociedade e no seu princípio, de modo que a instituição - modo de engendramento do social - aparece dando forma às relações sociais e produzindo-as (cf. LT, [1976a] 2007, p. 295). Estamos diante da sociedade moderna, uma sociedade histórica por excelência ${ }^{67}$, pois acolhe os efeitos da divisão e da história.

Nela, os atores sociais são capazes de questionar sua própria divisão, sua própria história, eles se veem às voltas com a possibilidade de produzirem seus próprios discursos, suas próprias e diversas explicações sobre si mesmos, sobre a ordem do mundo, sobre a ordem social, em termos de sua vida cultural e política ${ }^{68}$. É nela que se dá a constituição de um novo discurso - o discurso da ideologia, como sintetiza Chauí,

É elaborado, assim, um discurso que, partindo do discurso social (o discurso do social) e do discurso político (o discurso $d a$ política), se transforma num discurso impessoal sobre a sociedade e sobre a política. Essa passagem do discurso de para o discurso sobre constitui o primeiro momento na elaboração da ideologia. (CHAUÍ, [1977] 2011, p. 30, grifos da autora)

\footnotetext{
${ }^{66}$ Veremos mais adiante que Lefort apreende essa condição como passível de incitar o desejo pelo retorno a uma ordem unificadora do mundo social. Há sempre no horizonte o $U m$, capaz de restabelecer a unidade social.

${ }^{67}$ Nessa perspectiva, democracia e totalitarismo se inserem na dimensão histórica da sociedade moderna, em sua tentativa constante de produzir uma dissimulação da divisão (de travar os efeitos dessa divisão, de dissimular a irrupção da diferença) e uma dissimulação do histórico (de barrar a via da mudança ou de conter seu curso, de neutralizá-la).

${ }^{68}$ Ao mesmo tempo, no entanto, é aquela também onde se instaura uma ilusão que está no "coração da sociedade moderna" e da qual até mesmo Marx não consegue se livrar, de que a instituição do social pode dar conta ou razão de si mesma, abolindo a existência de um lugar outro. Nesse sentido, a perspectiva marxista da realidade participa desta ilusão, assim como as ciências humanas, saberes profundamente vinculados à ideologia e objeto de várias críticas por parte de Lefort, na medida em que figuram a ideia de um autoengendramento do social, isto é, a possibilidade de explicitar a origem, a lei de seu engendramento e de sua constituição. O comunismo, por exemplo, ao beber na fonte marxista, tende à afirmação do fechamento do espaço social, criando as condições para o totalitarismo.
} 
A ideologia, portanto, vem a ser um tipo de discurso através do qual os efeitos da divisão e da historicidade podem ser neutralizados sob o signo da representação. Assim, a ameaça que pesa sobre a ordem estabelecida pelo fato de estar dividida e pelo fato de ser histórica cria as condições para a vigência de um "discurso racional em si, fechado, [que] mascara as condições de seu próprio engendramento com a pretensão de revelar o da realidade social empírica." (FH, [1974] 1979b, p. 304) O que ela revela, no entanto, mantém um parentesco com o imaginário das sociedades pré-capitalistas, pois a ideologia também procura denegar a história, congelá-la na repetição do mesmo a fim de conjurar a ameaça do novo.

Nesta reflexão sobre o imaginário, a sociedade moderna vem a ser aquela em que a divisão social e a historicidade tornam-se questionáveis. Abre-se, então, a noção de uma realidade em si inteligível, isto é, da possibilidade de uma "operação de constituição do real” (ibid., p. 309), em que uma história ou uma natureza tornam-se inteligíveis, podendo ser objeto de reelaboração discursiva pela via da ideologia. Marx, na sua distinção entre a sociedade capitalista e todas as anteriores - denominadas précapitalistas - descortina-se para Lefort a possibilidade de entrever aquilo que marca a nossa condição moderna: o rompimento com uma ordem transcendente. Somente nesse registro conseguimos entender o pleno sentido que adquire na sociedade moderna o questionamento da divisão social e da história, em consonância com o engendramento de um discurso específico: a ideologia.

Nosso esboço toma como ponto de partida essa concepção que circunscreve a ideologia a um tipo de sociedade e que recusa, portanto, formalmente, a aplicação do termo a uma estrutura feudal, despótica ou sem Estado, nas quais o discurso tira sempre sua legitimidade de uma referência a uma ordem transcendente e não deixa lugar para a noção de uma realidade em si inteligível nem, simultaneamente, para a de uma história ou de uma natureza em si inteligível. (FH, [1974] 1979b, p. 298)

No momento em que o engendramento do social passa a ser estabelecido a partir de seu lugar-próprio e não mais a partir de um lugar-outro (regido por uma ordem mítica, religiosa), ocorre a emergência de um tipo particular de discurso que é a ideologia ${ }^{69}$. O seu trabalho, a sua obra (ouvrage) é a de "desarmar as oposições e as rupturas no duplo registro do espaço e do tempo" (FH, [1974] 1979b, p. 313), pois,

\footnotetext{
${ }^{69}$ Para Lefort, e neste momento identificamos um elemento que fará parte de suas análises sobre a democracia e o totalitarismo, a questão do espaço social é aquela de seu limite ou de seu "fora" (FH,
} 
[...] na exata medida em que surge a questão do engendramento do social a partir de seu lugar próprio - o domínio desse engendramento, os meios de denegá-lo e de contê-lo escondendo-o - emerge um tipo novo de discurso ocupado em desarmar as oposições e as rupturas no duplo registro do espaço e do tempo. (FH, [1974] 1979b, p. 313)

O "aparecer", o tornar-se "visível" do espaço social ocorre, justamente, porque já não está mais submetido a uma dada obra de ocultamento comandada pela ordem transcendente (mítica ou religiosa) que impedia o seu aparecimento, ou seja, a possibilidade de um questionamento da sua divisão e da sua historicidade. É importante frisar que, numa sociedade de formação pré-capitalista, a representação - mítica e religiosa - é de tal modo predominante que é capaz de neutralizar os efeitos da divisão e da historicidade. Quanto à sociedade moderna, comandada pela lógica social, é por meio da ideologia, este discurso dotado de representações denegativas, dissimuladoras, que se opera uma neutralização dos efeitos da divisão social.

Portanto, encontramos um Lefort às voltas com a dimensão simbólica, tomando o próprio Marx como ponto de partida, mas agregando novos elementos nesta interpretação. O ponto de partida é a eficácia do dispositivo simbólico no despotismo asiático, pois Marx não pode evitar reconhecer nesse despotismo essa eficácia simbólica, o que é "testemunhado pela própria designação do modo de produção em termos não econômicos” (ibid., p.310). Lefort faz a seguinte afirmação:

Procurando definir o despotismo asiático, a que já aludimos, abala sua construção, pois afirma que essa formação social tende a se reproduzir tal e qual, independentemente de todos os acontecimentos, guerras, migrações, mudanças de dinastia, e que a organização social está como que petrificada em decorrência da separação absoluta entre a comunidade imaginária e as comunidades rurais. Assim procedendo, incita inicialmente a que se recoloquem em questão as funções respectivas da produção e da representação, levando a supor que a primeira está subordinada à segunda. (FH, [1974] 1979b, p. 310)

A singularidade do despotismo asiático, assim como o de todas as formações pré-capitalistas, está no dispositivo simbólico, ou seja, no conjunto de representações, demarcando as condições de ocultamento, estabelecidas de maneira a impossibilitar a

[1974] 1979b, p.311). Aqui as noções de lugar-próprio e lugar-outro podem ser compreendidas, visto que designam dois modos de se conceber a ordem social. 
questão de uma oposição entre o imaginário e o real ${ }^{70}$. Na impossibilidade de uma dissociação entre imaginário e real, o real só se revela como determinável em virtude de uma palavra, mítica ou religiosa, que testemunha um saber que não poderia ser colocado em jogo.

\footnotetext{
70 Somente ao revisitarmos as sociedades "sem história", conseguimos perceber a relevância do dispositivo simbólico numa sociedade como a nossa, dominada pela experiência do real (uma experiência sem precedentes), pela ciência e pela técnica. Há elementos que Lefort busca identificar no político (para compreender a democracia, o totalitarismo) que somente se tornam identificáveis quando ele mesmo estabelece uma relação com o Antigo Regime, com aquilo que marca a mudança no dispositivo simbólico.
} 


\section{CAPÍTULO 3 - A ideologia}

\section{A ideologia enquanto "obra"}

A ideologia, segundo Lefort, só poderia ter surgido em um tipo de sociedade onde se divisa um "regime específico do imaginário", em que a ruptura com a ordem transcendente - mítica ou religiosa - abriu a possibilidade para um discurso não mais remetido a um fora, mas engendrado no próprio espaço social. A ideologia, como já anunciado, é ocultamento, um modo de denegar as oposições, as rupturas que ocorrem no âmbito das relações sociais efetivas. Assim, se ela assegura a dissimulação de alguma coisa é porque a ideologia "está comandada e sustentada por um princípio de ocultamento que veio ocupar o lugar daquele que rege o dispositivo simbólico de todas as formações pré-capitalistas" (FH, [1974] 1979b, p. 314)

O discurso ideológico, então, não pode existir a não ser em uma sociedade em que tenha havido uma quebra com a ordem transcendente. Dessa forma, abre-se a possibilidade de visar o real, de aparecer o espaço social e, dessa forma, de emergir um novo tipo de discurso que é a ideologia, calcada sobre a divisão social. O que marca a especificidade deste discurso e o que justifica a sua inexistência em outras formas é o fato de que reconhece a historicidade e a divisão, diferentemente do discurso mítico, religioso que estava remetido a outro lugar, externo - a outro mundo - e que, portanto, permanecia como saber transcendente, contendo uma ideia de tempo e de lugar sempre determinados.

A ideologia, portanto, compõe o imaginário da sociedade histórica. Nesta sociedade, a religião emigrou para a relação social, ou seja, ela deixou de constituir aquele saber, aquela palavra, cujo fundamento não poderia ser colocado em jogo pelo movimento efetivo do conhecimento, pela invenção técnica, pela interpretação do visível. Assim, para Lefort, o discurso ideológico e o discurso religioso se diferenciam, não somente porque o primeiro tende a se desenvolver nos limites do espaço social, mas também porque, ao fazê-lo, a ideologia põe-se ao lado do conhecimento "científico", que pretende ser o autodeciframento do real. A distinção também está no fato de que o discurso ideológico está submetido aos efeitos do incessante transtorno social que é 
engendrado pelo capitalismo, pois, como ele afirma, "instituições, mentalidades e comportamentos coletivos se modificam, núcleos de potência se deslocam, camadas burguesas que retiram seus ganhos e poder de fontes diferentes entram em oposição" (LEFORT, p. 313-FH).

Lefort compreende a ideologia como um discurso segundo, pois "segue as linhas do discurso instituinte" (FH, [1974] 1979b, p. 315), ou seja, ela nasce como desdobramento de um discurso primeiro que contém em si mesmo todos os signos da criatividade histórica, de um questionamento nascido, no âmago da divisão social, entendida como brecha, como fenda na sociedade. Isso quer dizer que ela não se dissocia do jogo político, das relações de embate entre as classes, das lutas sociais que surgem em cada aqui e agora, no espaço social histórico ${ }^{71}$.

A ideologia, enquanto "dobra" do discurso instituinte, nasce e se mantém presa a ele, com vistas a reconhecê-lo e a denegá-lo ao mesmo tempo. Ela conhece e reconhece muito bem as propriedades da sociedade histórica, de sua divisão, pois resulta de um trabalho de interpretação dos enunciados abertos, questionadores, criativos, com vistas a anular toda a sua expressividade, a sua descoberta. Ela é, portanto, uma afirmação, uma certeza, uma determinação sobre o significado da sociedade, das relações sociais, do poder, pois procura "desarmar as oposições e rupturas no duplo registro do espaço e do tempo" (ibid., p. 313). A ideologia está na dependência do discurso instituinte, dissimulando o histórico pela fantasmagoria do "novo", do "moderno", ou seja, criando a ilusão para mascarar a diferença temporal. Ela também realiza o projeto de homogeneização social, criando respostas para as questões surgidas com a divisão social, entendida a partir dos conflitos de classe, étnicos e assim por

\footnotetext{
${ }^{71}$ Thompson comenta esta perspectiva de Lefort que pensa a ideologia como "dobra", considerando um problema: como é possível distinguir entre discurso instituinte e discurso instituído, sendo este pensado como discurso da dissimulação, sem que se pressuponha algum critério de "real", a referência segundo a qual o processo de instituição pode ser circunscrito?(cf. THOMPSON, 1982, p. 675). Primeiramente, podemos dizer que Lefort não pensa a ideologia como um discurso que se "distingue" do discurso instituinte, como se houvesse uma separação e no seu meio o real como algo dado, entendido como uma verdade capaz de falsificar a ideologia. Como veremos mais adiante, o real não pode ser afirmado frente à ideologia pura e simplesmente, mas depende de um trabalho de pensamento, de crítica das ilusões que se dá também no reenvio ao discurso instituinte. Assim, se ele pode ser pensado por Lefort como aquilo "que denuncia a possibilidade do encobrimento" (FH, [1974] 1979b, p. 309) é porque ele está sempre em suspensão, à espera deste trabalho. Se podemos definir algum critério para aquela distinção, pensada por Thompson (1982), este não está no real dado, mas sim neste trabalho de crítica da ideologia e de reenvio ao discurso instituinte, o qual pertence a cada tempo histórico. Como afirma Molina, neste mesmo sentido, não se deve possuir o conceito de real, pois ele é "conceito cuja identidade é imutável, indiferente ao tempo que passa, isto é, às mudanças que afetam o pensamento e a ação humanas."(MOLINA, 2005, p. 153). De acordo com Molina, "a verdadeira realidade social não pode ser concebida independentemente da ideologia" (MOLINA, 2005, p. 159).
} 
diante: o que a ideologia faz é neutralizar a história, dissimular a irrupção da diferença e desarmar a interrogação (LT, [1976a] 2007, p. 281).

Seu trabalho, ou melhor, sua "obra" é ocultar a divisão social como engendramento da história pelas lutas contra a opressão, pela expressão e reivindicação do desejo como negatividade pura e tende a criar novos mecanismos, novas políticas de regulação do desejo de oprimir, característico dos "Grandes", como vimos em Maquiavel.

Para compreendermos o modo como Lefort pensa a ideologia, enquanto linguagem sobre a divisão, devemos nos remeter a Merleau-Ponty ([1952] 2004), o qual parte da ideia de que não há transparência absoluta no tecido da fala, mas sim, opacidade, silêncios, lacunas, coisas não-ditas. A palavra, então, não se limita ao que é dito, mas contém um "fundo de palavra", sendo uma "dobra" (cf. MERLEAU-PONTY, [1952] 2004, p. 71), exprimindo-se tanto pelo que diz, como pelo que não diz e, portanto, se deixa apreender como linguagem dupla co-habitando uma fala. Dessa maneira, temos uma linguagem empírica, na qual permanece oculta uma linguagem em segunda potência, cuja característica principal é a de manter a significação obscurecida, opaca, fechada em si mesma.

Se a linguagem não é inteiramente explícita e se a divisão deixa de ser pensada como estando "na sociedade", para exprimir-se como "pensamento da divisão", como linguagem da divisão, então, a ideologia é este discurso em segunda potência, "discurso enunciador da ordem do mundo" (FH, [1974] 1979b, p. 307), procurando simular um saber geral sobre o social e sobre o político ${ }^{72}$. Isso quer dizer que a ideologia mantém uma relação com o simbólico, pois o denega e cria uma ordem imaginária, fundada em determinações sobre o significado do social. Esta ligação foi pensada por alguns comentadores da obra de Lefort, em que se destaca a perspectiva de Abensour (2002), explicitando que a ideologia na democracia é aquela que procura apanhar o simbólico, apropriá-lo e domesticá-lo, no que diz respeito, especialmente, àquilo que resiste e procura se evadir de toda a determinação, isto é, tudo o que remete à ordem simbólica entendida como indeterminação do social (cf. ABENSOUR, 2002, p. 709). De acordo

\footnotetext{
${ }^{72} \mathrm{O}$ político pode ser aqui apresentado como aquele que permanece oculto na sociedade histórica, assim como o simbólico. Ele é pensamento que procura permanecer em contato com a ordem simbólica, justamente para decifrar o social, mantendo-se articulado também à ideologia. Mais adiante retomaremos esta articulação.
} 
com Breckman (2012, p. 34), uma vez que o simbólico passou a fazer parte de uma história da desmistificação produzida pelo racionalismo, ele também passou a fazer parte da lógica da ideologia como discurso da cientificidade e da objetividade ${ }^{73}$. Na perspectiva de Flynn (1984), por sua vez, a ideologia é a tendência, o desejo de fechar o gap, a distância entre o simbólico e o real, de tal forma que ela procura apagar este distanciamento, isto é, o intervalo que há entre o discurso instituinte e o instituído. $\mathrm{O}$ que ela faz também é "converter as marcas simbólicas em determinações naturais", como fez o discurso humanista que situou a divisão social no interior da sociedade, sendo simultaneamente, uma revelação e uma denegação da instituição do social ${ }^{74}$. Na linha de Vries (2008), a ideologia busca "imprimir violentamente o simbólico no real" (VRIES, 2008, p. 251), criando sua determinação, enquanto tendência inescapável do imaginário moderno.

Um elemento importante a salientar é que Lefort compreende a sociedade histórica como aquela onde ocorreu um desintrincamento entre o poder, a lei e o saber que deve ser entendido como da ordem do simbólico. Quando houve um desintrincamento do político e do mítico-religioso, instituiu-se uma nova experiência da identidade social que vem a ser concebida pela articulação entre poder e saber. Por isso, devemos compreender que a ideologia constitui um tipo de discurso em que há um saber, uma argumentação e uma interpretação do real que tem o efeito de ocultá-lo, de afirmá-lo e de determiná-lo. Mas é importante esclarecer que a ideologia não pode ser entendida como reflexo invertido do real, pois o real, para Lefort, é "trama" (FH, [1974] 1979b, p. 300) aberta, sendo sempre "suposto" em cada aqui e agora por meio dos acontecimentos e das relações sociopolíticas, significando que ele não está dado, pois é sempre criação que se constitui por meio das respostas concebidas pelos agentes sociais em relação à questão-origem. O real, então, está sempre à "prova", pois é o "lugar de uma História" (HT, [1976c] 1976b, p. 197) que se constitui pelas ações práticas que são desencadeadas pelo trabalho da interrogação.

\footnotetext{
${ }^{73}$ Molina segue esta mesma linha de discussão, ao compreender que o discurso científico compartilha a mesma pretensão do discurso ideológico, no sentido de produzir o mito de uma linguagem originária, capaz de fundar e dizer tudo sobre o real (cf. MOLINA, 2005, p. 167).

${ }_{74}$ De acordo com o autor, a ideologia humanista é a tentativa de "absorver o simbólico no domínio do real: seja convertendo as marcas simbólicas em determinações naturais como no materialismo, seja constituindo um 'discurso regrado pela ilusão de um registro do real a partir do real, que tende a dar a si mesmo como um discurso anônimo no qual o universal fala de si mesmo', como no idealismo. Em cada caso, a distância entre o discurso instituinte e o discurso instituído, a distância entre o discurso sobre a lei e a lei, ela mesma, é, em princípio, denegada." (FLYNN, 1984, p. 17-18).
} 
Não é por acaso que Lefort quase não fala, nem utiliza com muita frequência a palavra "real”, pois não é possível dizer o que ele é, pois está sempre na dependência de um deciframento, de um trabalho de pensamento, é algo que se "conquista" e que ocorre no jogo da determinação-indeterminação. Dessa maneira, o real é complicação, podendo ser encontrado nas entranhas do discurso ideológico, entre os pensamentos e o discurso sobre a política que são criados pela ideologia. $\mathrm{O}$ real nada é fora do movimento de pensamento que nos leva até ele em cada época pela crítica das imagens, ilusões e que, portanto, pode ser nomeado como o "impensado da ideologia", como o não conhecimento que permanece em suspenso e denuncia sempre a impossibilidade do recobrimento, criando os possíveis na sociedade histórica. Nesta sociedade, portanto, o real desprendido do imaginário é entendido como indeterminado, como lugar de uma História (cf. HT, [1976c] 1976b, p. 197), constituído não só pelo jogo dos acontecimentos, mas também pela denegação operada pela ideologia.

Grupos sociais e indivíduos participam, então, da mesma lógica ideológica, uma vez que portam em suas falas, em seus pensamentos, o discurso da ideologia, constituindo-se como seus agentes propagadores. Isto significa que todo pensamento na sociedade histórica pode ser entendido como pensamento ideológico à espera de um deciframento que permanece em suspenso pelo tempo necessário, ou seja, até que a crítica possa ocorrer no bojo dos acontecimentos.

A ideologia é da ordem do saber, ela implica um certo modo de interpretação do real, um certo modo de argumentação e de afirmação que não somente requer a adesão, mas mobiliza o pensamento dos homens. Não podemos dizer simplesmente que eles estão sob sua influência, porque eles também são seus agentes. Representantes de um mesmo saber, portadores de um mesmo discurso, eles não estão colocados nem fora deles próprios nem separados de outros como por uma pulsão, mas também se representam, se realizam e comentam sem relaxar seus atos próprios. Qualquer definição que lhe dermos, a ideologia é sustentada por um pacto ao termo do qual cada um se assegura de seu julgamento segundo o critério de sua identificação com os outros, ajusta o que presta a transmitir, enfim destina seu pensamento ao limite da cumplicidade. (HT, [1976c] 1976b, p. 135-136)

Na sociedade moderna, a delimitação de uma prática da política faz com que o poder venha a se constituir em um polo separado da lei e do saber. Com isso, ele tornase destituído de uma explicação para sua gênese, da mesma forma que ocorreu com o social, significando, por um lado, que ele se encontra na condição de sempre ser reestabelecido pelo discurso que se desdobra no plano da lei e do saber, na diferença 
entre o dizer e a coisa dita e, por outro, que, para dar conta desta origem que não se resolve mais pelos mitos e pela religião, abre-se a possibilidade de que haja um discurso que elabore ativamente a imagem de uma essência da política, isto é, a ideologia. Isto significa que o poder está sempre na condição de ser apreendido pelo discurso da lei fundadora do político e fundada por ele -, isto é, por um discurso e um debate abertos sobre os direitos, nos quais estão implicadas as opiniões, costumes e conhecimentos ${ }^{75}$, ao mesmo tempo em que são apanhados pela ideologia.

Assim, na disjunção entre poder e saber, ou melhor, entre poder e discurso, a ideologia pode ser entendida como "poder do discurso", recobrindo o "discurso do poder", ou seja, ela recobre toda a significação adquirida pelo poder, na sociedade histórica, no sentido de que o poder se constitui através do debate ininterrupto, do questionamento constante operado, na esfera jurídica e no espaço público, compreendido como espaço simbólico. A ideologia procura criar determinações, "fórmulas" prontas para serem aplicadas que seguem a linha dos novos questionamentos, criando sempre uma representação, uma imagem da divisão social.

Em cada forma de sociedade, a relação da ideologia com o poder se diferencia com relação à democracia e ao totalitarismo, por exemplo. No caso da primeira, a ideologia encontra-se desnivelada em relação ao poder, favorecendo a constituição de um discurso sobre o poder que pode tanto favorecer uma imagem sobre as posições de poder na sociedade (a distinção entre Estado e sociedade civil, a distinção entre dominantes e dominados) como é o caso da ideologia burguesa; como esfumá-las, como veremos na ideologia invisível. Já no totalitarismo, o poder é "apanhado pela ideologia" e, dessa forma, torna-se discurso do poder, pois a ideologia está encarnada nele.

A ideologia é "obra de ocultamento" (FH, [1974] 1979b, p. 313) da divisão e da história, pois toda vez que há mudanças nas mentalidades, nos comportamentos coletivos ou, ainda, quando núcleos de potência se deslocam, em termos das relações de poder entre as classes, por exemplo, ela rearranja seus próprios enunciados para dar

\footnotetext{
${ }^{75}$ É importante aludirmos a uma reflexão que, no entanto, não desenvolveremos e que trata da relevância do debate sobre os direitos humanos como fundamento da política e como crítica da ideologia, pois Lefort encontra na fala e na consciência destes direitos a possibilidade do estabelecimento de uma ruptura com a ideologia. Ele pergunta: "a luta pelos direitos do homem torna possível uma nova relação com a política? - preferiríamos assim perguntar para sugerir que se trata somente de interrogar-se a respeito das condições de um pensamento e de uma ação políticos em ruptura com a ideologia. Parece que se deve dar uma resposta positiva a esta questão e sustentá-la sem hesitar face às sociedades democráticas em que vivemos." (ID, [1980b] 1983a, p. 56-57). Neste sentido, abre-se uma reflexão sobre o impacto crítico das lutas por direitos no tocante à ideologia, a qual será abordada no quarto capítulo.
} 
conta do recobrimento, ou seja, para que seus enunciados continuem fazendo sentido e conferindo uma correspondência à nova trama das relações. Assim, sempre que novas "fendas" são abertas pelos agentes sociais no trabalho de contestação da ordem estabelecida, isto é, que novos acontecimentos surgem através de um retorno à questãoorigem, a ideologia rearticula seus enunciados, seus signos representativos para entulhar e fechar a "brecha" aberta na sociedade. Como afirma Lefort,

A ideologia deve cumprir sua obra de ocultamento da divisão modificando seus enunciados ou recorrendo simultaneamente a uma multiplicidade de representações para entulhar fendas abertas pela mudança na 'racionalidade do real'. Aqui se desvenda a relação singular que a ideologia mantém com a 'sociedade histórica'. (FH, [1974] 1979b, p. 313)

Toda vez que os agentes sociais elaboram um discurso na vivência dos acontecimentos, procurando reenviar seus pensamentos em contato com o instituinte, com a questão-origem, o que fazem é manter aberta a interrogação que se alimenta do tumulto, da desordem à qual se encontram expostos e em suspensão, e que os fazem abrir uma nova perspectiva, uma nova compreensão que irá redirigir, reoriginar suas relações. Isso quer dizer que o social é reinvenção permanente, na tentativa de se desprender do pensamento ideológico do qual é cativo. O social histórico, portanto, constitui-se como uma tarefa que se dá em recomeço, pois no mesmo instante da criação, tem-se a petrificação, a tentativa de restabelecer a certeza, a união, a unidade, a determinação, a segurança do adquirido. Nesse sentido, ele é marcado pela busca de si mesmo, é linguagem se fazendo, operante, desdobrando-se constantemente em novas e velhas ideologias que também passam a ter uma História. Cada sociedade, em cada época, faz a experiência de seu próprio engendramento, de sua instituição, mas também de sua denegação ${ }^{76}$.

A ideologia acomoda-se bem com versões heteróclitas, pois, para se manter como autodeciframento do real, precisa rearticular sua fala, manter-se colada às novas leituras de mundo, concebidas pelos agentes sociais, ser complementar às representações de cada época. É por isso que encontramos referenciais do passado e do futuro, éticos, tecnológicos, científicos, culturais, pois a ideologia é um "saco de gatos"

\footnotetext{
${ }^{76}$ É importante salientarmos que, embora a ideologia opere a denegação e o ocultamente do simbólico, no totalitarismo, esta operação é levada até suas últimas consequências, no sentido de promover a "foraclusão" do simbólico, como afirma Flynn (1984, p. 17-18), denegando a divisão social pela identificação de uma comunidade imaginária como unificada no corpo do tirano ou do Egocrata.
} 
(ibid., p. 316), afirma Lefort; ela mantém discursos díspares para manter sua eficácia de resposta geral. Trata-se de um grande discurso, em que diferentes atores sociais, oriundos de esferas diferentes - econômica, política, jurídica, estética, pedagógica, etc. - compartilham a tarefa de formular enunciados ideológicos. Temos, então, um discurso sobre a política, sobre a economia, sobre a educação, sobre o corpo, sobre o pensar e o agir humanos em todas as esferas, compondo "uma malha do discurso geral sobre o social” (FH, [1974] 1979b, p. 316).

A ideologia constitui uma espécie de discurso que está sempre à prova: sempre sujeita a uma disjunção - entre o discurso sobre o social e o discurso social -, sempre sujeita à prova da realidade, podendo ser constantemente contraditada, por exemplo, pela desigualdade que subsiste na sociedade, de modo que há sempre a possibilidade de uma reversão da ideologia (cf. LT, [1979e] 2007, p. 397).

Um aspecto central que devemos salientar é a transformação da ideologia. Ela contém em si mesma um princípio que comanda sua mudança, pois, para Lefort, ela encontra-se animada por uma contradição interna.

O fracasso do processo de dissimulação da instituição do social determina, por uma parte, a necessidade de sua reorganização. Porque a ideologia não pode realizar-se sem se descobrir, isto é, sem se expor como discurso, sem deixar aparecer o distanciamento deste com respeito àquilo que fala, ela implica num devir no qual se reflete a impossibilidade de apagar suas pegadas. (FH, [1974] 1979b, p. 316)

A ideologia, a fim de que possa cumprir sua "obra de ocultamento da divisão", está sempre modificando seus enunciados e recorrendo a uma multiplicidade de representações; a sua "obra de ocultamento" está sempre submetida aos seus efeitos, ou seja, em seus fracassos, ao tentar corrigi-los, deixa aparecer aquilo que se denomina "real": aquilo que denuncia a impossibilidade do encobrimento. É por isso que a ideologia está submetida a uma transformação recorrente: à medida que sua "obra de ocultamento" falha, à medida que fracassa sua tentativa de encobrimento, um novo discurso ideológico passa a ser elaborado.

Ao refletirmos sobre a ideologia, estamos, na verdade, estabelecendo uma compreensão sobre a lógica do imaginário social na sociedade histórica, na qual o "real" passa a ser visado como tal, ocorre a articulação das relações sociais aqui e agora e, mais ainda, elas passam a ser questionáveis. A sociedade histórica é, portanto, aquela 
que acolhe a indeterminação, justamente porque nela se abre a possibilidade de seu próprio questionamento, fazendo com que as relações sociais não se encontrem mais petrificadas. Até mesmo a obra de ocultamento estabelecida pela ideologia submete-se a este imperativo, pois, a partir do momento em que seus enunciados não atingirem mais os efeitos desejados e que se revele como discurso, submeter-se-á, então, a novas elaborações, a um deslocamento e mesmo a uma reviravolta de seus enunciados.

É nesse sentido que, na ótica de Lefort, não é possível reduzir a ideologia à ideologia burguesa. Esta constitui apenas um momento daquela, de tal forma que escrutando os seus fracassos, é possível esclarecer a gênese da ideologia totalitária; e, assim também, no fracasso desta, a gênese da ideologia "invisível". Nesta perspectiva, verificamos que há uma história das ideologias, pois elas se transformam ao longo do tempo, em virtude de sua contradição interna. Há um debate entre as ideologias, como afirma Lefort no artigo "Permanência do teológico-político?" (PP, [1981b] 1991, p. 265), pois elas procuram definir a identidade social.

Se quisermos apreender como ocorre a gênese de uma nova ideologia, devemos reter o princípio de que ela não cessa de se dar sob o efeito de choques que a levam a se transformar para garantir certezas sobre o social. Dessa maneira, o seu deciframento ocorre nestas circunstâncias, pela compreensão de suas transformações em cada forma de sociedade (cf. LT, [1982a] 2007, p. 467).

A seguir, caracterizaremos inicialmente a ideologia burguesa, uma espécie de ideologia "matriz" cujos princípios e contradições internas servem de base para o estabelecimento tanto da ideologia totalitária, quanto da ideologia "invisível".

\section{A ideologia "dita" burguesa}

Ao iniciarmos esta discussão, partimos de um questionamento sobre as razões que levaram Lefort a considerar esta ideologia como "dita" burguesa. Se observarmos suas reflexões sobre ela, percebemos que ele não a compreende unicamente como lógica das ideias dominantes da classe burguesa como no registro marxista. Ele não desvincula tal ideologia desta classe, mas também não reduz a compreensão que tem sobre ela, sobre o seu surgimento, a esta classe. O trecho seguinte ilustra esta perspectiva, em que ele diz claramente que o discurso dessa ideologia não está preso a uma classe: "Não 
queremos dizer que o discurso emane de um agente ou de uma série de agentes que seriam apenas representantes da classe dominante" (FH, [1974] 1979b, p. 318). Em outra passagem, ele também afirma que a ideologia não se prende a nenhuma classe:

Já dissemos suficientemente que a ideologia antiga não era a da burguesia a fim de não cairmos na ilusão de supor que ela se teria tornado a de uma nova classe - por exemplo, a da tecnocracia - como se gosta de repetir. (FH, [1974] 1979b, p. 335)

Ao assumir esta perspectiva, Lefort coloca em jogo o que já discutimos acima sobre sua compreensão de que a ideologia é da ordem do saber e que seu entendimento não se dissocia da forma de sociedade na qual ela emerge. Assim, a questão a tratar não diz respeito necessariamente ao papel da classe burguesa no estabelecimento desta ideologia, uma vez que não está em discussão somente o exercício de dominação desta classe, mas sim voltar-se para as propriedades assumidas por este discurso, na época e no tipo de sociedade em que emergiu.

Seguindo tal compreensão, Lefort identifica que esta ideologia se coaduna aos princípios-chave da democracia burguesa ${ }^{77}$, ao discurso burguês, essencialmente, mas também ao discurso antiburguês - em sua versão socialista ou anarquista -, justamente porque há em comum entre estes discursos a experiência de uma nova forma de sociedade em que o real passou a ordenar o todo social. Dessa maneira, eles trazem, em sua linguagem, um ponto de vista sobre a verdade do real, fixando a origem dos fatos e a ordem das ações e das relações sociais, por meio da objetivação do social, seja qual for a perspectiva adotada ${ }^{78}$.

Para que possamos melhor compreender estas questões, iniciemos a reflexão pelo entendimento da forma de sociedade na qual o discurso da ideologia burguesa se instituiu. Este discurso que encontrou seu apogeu no século XIX é aquele que substituiu

\footnotetext{
${ }^{77}$ Lefort utiliza a expressão démocratie bourgeoise para se referir a esta forma de sociedade em que há a ideologia burguesa. Embora empregue esta expressão, em seus escritos, de uma maneira geral, mantém a crítica à fala de seus contemporâneos que veem a democracia apenas como burguesa. Quando se refere à ideologia invisível, já observamos que utiliza outra expressão: démocraties occidentales.

${ }^{78} \mathrm{O}$ contradiscurso burguês, embora procure ressaltar a irracionalidade do presente, em relação ao que é apresentado como real e como verdadeiro pelo discurso burguês, não se distingue desta ideologia, porque as ideias que apresenta também partem do mesmo princípio de uma transparência da sociedade para si mesma. O socialismo e o anarquismo, então, podem ser nomeados e identificados como contradiscursos da ideologia burguesa, porque procuram contestar as representações desta ideologia, mas a mantém na mesma lógica discursiva. Teremos a oportunidade de discutir as propriedades deste discurso, no quinto capítulo que apresenta uma crítica à ideologia, indicando que ela tem o efeito de produzir comentários, exegeses que têm a pretensão de serem críticos, mas que, por fim, acabam por compartilhar e, até mesmo, aprofundar certos princípios que estão embutidos no discurso ideológico.
} 
a transcendência divina por uma transcendência de ideias, sendo regido pela ilusão de uma leitura do real a partir do real, vivendo de uma recusa explícita ou implícita a um lugar-outro de onde se extraía a ordem social e a ordem do mundo. Este discurso, ainda que tenha encontrado apoio na religião, em certas épocas e para certas camadas da classe dominante, está submetido ao ideal de um conhecimento positivo sobre o social, no qual impera a racionalidade e a objetividade. Dessa maneira, constatamos que ele vem a ser um tipo de discurso que tem sua origem no social, sendo, portanto, instituído pelas relações sociais - pela divisão entendida como discurso da divisão -, ao mesmo tempo em que as institui, tornando-se um discurso sobre o social, assumindo, então, sua condição de discurso que fala do alto, sob o signo da transcendência das ideias, mas que do real não se separa.

Quando Lefort afirma que a ideologia burguesa mantém o "mesmo desvio da transcendência das ideias" (FH, [1974] 1979b, p. 317), isto quer dizer que ele reconhece a existência de um parentesco ${ }^{79}$ entre ela e o discurso mítico, no sentido de que mantém a mesma posição de exterioridade, embora, neste caso, a referência seja o objeto, o fato e não um lugar-outro. Assim, compreendemos que a ideologia mantém a mesma lógica de deslocamento, mas que, neste caso, não se dá para um além-social e, sim, no próprio social, enquanto desdobramento do discurso do social.

Para compreendermos melhor esta ideia, retomamos o significado da constituição de diferentes domínios na sociedade moderna e, por conseguinte, de diferentes linguagens. Na sociedade burguesa do século XIX, a ideologia vem estabelecer-se em consonância com um acontecimento central que é a delimitação do Estado, da empresa, da escola, do asilo, das instituições modernas em geral. Em cada um destes espaços há uma ordenação constituída por uma atividade de linguagem, em que os agentes sociais são referenciados uns com relação aos outros, em que a palavra circula, de maneira a ordená-los e a diferenciá-los como pais, filhos, irmãos, trabalhadores, jovens e pessoas mais velhas. Esta linguagem, apenas para retomar o que já apontamos no tópico anterior, constitui-se como discurso instituinte, isto é, como discurso do social, engendrador de novas relações e de novos conflitos sociais,

\footnotetext{
${ }^{79}$ Esta relação entre discursos evidencia o tipo de reflexão desenvolvida por Lefort, o qual leva sempre em consideração que não há uma disjunção total entre eles, pois não há um ponto de origem na elaboração de um novo discurso, uma vez que ele se faz como discurso-outro e, portanto, pode conter enunciados que o contradizem, como também certos prolongamentos.
} 
suscitando a constância de uma identidade ausente e de uma dissolução iminente do social.

A ideologia burguesa, em resposta a esta indeterminação e na disjunção que opera em relação a esta linguagem, deve ser compreendida como linguagem do discurso instituinte que é desdobrada, que é colocada em "segunda potência", "que busca sua distância com relação à primeira e tenta conjurar o risco que a habita" (FH, [1974] 1979b, p. 321). Assim, esta ideologia coloca-se na posição de exterioridade ao discurso do social, pois precisa se exibir como discurso sobre o social ${ }^{80}$, afirmar certezas que pareçam irrefutáveis sobre o social e plenamente identificáveis nas ações práticas dos homens.

Para que esta exterioridade se torne possível, Lefort afirma que ela vem a ser garantida pela regra que, ao mesmo tempo, testemunha a encarnação da ideia na relação social. Ela também exprime a universalidade que rege o discurso mítico, visto que se constitui como um corpo de prescrições que estabelece normas de conduta, aquilo que é bom, mau, justo, injusto, ao mesmo tempo em que define a posição de cada um na hierarquia social, constituindo, portanto, para os sujeitos que as aplicam, a condição do saber e do agir em sociedade, a lhes fornecer a segurança do real e do inteligível.

Em cada uma das esferas e das instituições que mencionamos há um ordenamento das relações estabelecidas entre seus agentes pela elaboração de um discurso calcado na regra. Este discurso nomeia o real e define as posições de todos os sujeitos sociais, fixa o que vem a ser a distinção entre a civilização e a barbárie, a humanidade e a sub-humanidade. Ele estabelece a ordem e a verdade sobre os fatos, encerra-os numa representação objetiva, constituindo-se numa ideia que é, simultaneamente, norma e representação. Dessa maneira, a ideologia burguesa contém um duplo caráter, pois afirma uma verdade que define as condições tanto para o saber, quanto para o agir, estabelecendo a posição de cada um na ordem social.

Este discurso que ordena o mundo, também fixa um valor positivo e universal para certas instituições sociais, trazendo, em sua linguagem, certas palavras que fazem desta ideologia um texto escrito em maiúsculas, como Humanidade, Progresso, Vida e

\footnotetext{
${ }^{80}$ É importante salientar que, na ideologia burguesa, no desdobramento que a faz erigir-se como discurso do alto, em maiúscula, afirmando uma vista sobre o social, exterior a ele, mantém-se o reconhecimento do estatuto discursivo da sociedade. Diferentemente, portanto, do que ocorre no totalitarismo, como veremos adiante.
} 
Natureza, ou, ainda, outras que fazem parte do imaginário da democracia burguesa como Propriedade, Família, Ordem, Sociedade, Pátria. Isso significa que elas carregam uma significação que fixa uma verdade válida para todos a despeito das diferenças que existem e que se constituem como realidade, isto é, como aquilo que permanece em relação ao recobrimento. Veremos dois elementos desta nova linguagem - a noção de Progresso e de Desenvolvimento e, depois, a ideia de Família.

A noção de Progresso está presente na linguagem da ideologia burguesa, com o intuito de neutralizar o perigo da história, pois contém a ideia de que o desdobramento temporal ocorre em torno de algo que já se anunciou como "germe" ou "larva", isto é, como algo que já existira desde o início e que vai crescendo ao longo do tempo, o que nos impede de compreender a história como sendo sinônimo de criação e de transformação.

A ideologia oculta todos os aspectos que constituem a família em sua realidade para manter uma ideia e um ideal de Família, sendo considerado como universal, tornando-a também circunscrita no campo social distante de outras instituições. Enquanto ideia e ideal, a ideologia não pode dizer tudo, nem mostrar todos os aspectos que compõem a realidade, mas afirmar uma só e mesma ideia de Família ${ }^{81}$.

$\mathrm{Na}$ ideologia burguesa, a regra é capaz de fornecer a segurança do real e do inteligível e é graças a ela que se desdobra um imaginário da autoridade, fazendo aparecer os traços do burguês, do patrão, do pai de família, como já dissemos.

Neste sentido, o discurso sobre o social só pode manter sua posição de exterioridade frente a seu objeto figurando a garantia da regra que, em sua existência, testemunha a encarnação da idéia na relação social. A própria posição da garantia é explícita. Está inscrita na representação. Todo um imaginário se desdobra fazendo aparecer os traços do burguês, do patrão, do ministro, do pai de família, do pedagogo, do militante, etc. (FH, [1974] 1979b, p. 318)

Em cada uma das esferas de atividade, em cada instituição social, em cada domínio, temos o enunciado da regra. O que nos leva a considerar, a partir de Lefort, que o discurso da ideologia burguesa se dá como uma malha, como um tecido feito a partir do entrecruzamento de diversos discursos sobre o social que são proferidos em

\footnotetext{
${ }^{81}$ Essa busca pela correspondência entre ideias e real, conforme veremos é o que constitui a força do discurso da ideologia burguesa, bem como sua fraqueza, comandando sua contradição interna e sua transformação.
} 
cada campo - político, estético, jurídico, econômico - e que, portanto, nos impede de compreendê-la como um discurso dominante, mas sim como "discursos sociais dominantes" (HT, [1976c] 1976b, p. 202). Como vimos, trata-se de discursos que se desdobram em diferentes lugares da sociedade burguesa - na família, na empresa, na indústria, no Estado - e que compartilham a mesma lógica, pois estes discursos formamse em função da diferenciação de domínios de atividades e de relações ${ }^{82}$. O que nos leva a considerar que há certezas, determinações que são esparsas, ou seja, na sociedade burguesa há verdades sustentadas pela ideologia em diferentes esferas. Em outras palavras, isso significa que há vários polos em que ocorre a produção da verdade, contribuindo para criar várias imagens para aquilo que é o homem, para sua identidade. Há um entrecruzamento entre estes discursos que permitem, então, desprender um “perfil geral” desta ideologia (cf. HT, [1976c] 1976b, p. 202) ${ }^{83}$.

Com a ideologia burguesa, tudo se enuncia pelas regras e pelos valores proclamados, de modo que, quando os sujeitos falam, mobilizam signos burgueses da coesão social - Estado, Povo, Nação - que lhes oferece uma essência e uma identidade. Ao afirmarem sua articulação com a regra e, por sua vez, sua posição na sociedade, reafirmam sua diferença com relação a outros sujeitos sociais, um traço que se evidencia no distanciamento estabelecido entre aquele que fala e o outro. Distanciamento que se reveste de distinção a partir do momento em que o sujeito que fala, eleva-se porque seu vínculo social define-se pela regra, ou seja, profere a sua condição no momento em que a enuncia (enquanto burguês, enquanto pai de família), ao mesmo tempo em que figura o outro como o operário, como o filho. Sob o imperativo da regra, veicula-se um saber sobre a divisão social, considerada como surgindo da ordem das coisas, sendo ocultadas as suas contradições. Dessa maneira, o discurso ideológico desenvolve-se sob o signo da impessoalidade, deixando explícita a figura dos subordinados e a legitimidade da subordinação como se fosse inscrita na realidade, camuflando, assim, a divisão social. Com a ideologia burguesa, segundo Lefort, se enuncia

\footnotetext{
${ }^{82} \mathrm{O}$ ponto de partida de Lefort não deixa de ser a divisão do trabalho, como quando faz referência a alguns trechos da obra de Marx e Engels, extraídos de A ideologia alemã (MARX e ENGELS, 2007), para considerar a alienação segundo as diversas categorias instituídas no mundo do trabalho - juristas, políticos, moralistas, religiosos -, enquanto constituídas como domínios distintos que se afirmam como verdadeiros e universais (cf. HT, [1976c] 1976b, p. 202).

${ }^{83}$ Este traço da ideologia burguesa, como veremos mais à frente, não estará presente na ideologia totalitária, assim como não está no discurso mítico, onde a verdade enquanto saber se concentra em um único polo, no caso de regimes despóticos, na figura do príncipe que se constitui como uma autoridade com sanção divina e, no caso do totalitarismo, no Partido.
} 
[...] a regra que determina o lugar, a classificação, a função dos agentes e comanda suas relações; a autoridade, por sua vez, suposta a se engendrar e a ser a garantia; a finalidade mesma da instituição. E, da mesma forma, dando plena figura aos detentores da autoridade: o pai, o mestre, o patrão, o homem do Estado; e, da mesma forma, dando plenamente figura à hierarquia; e, ainda, oferecendo plenamente figura àquele que obedece e que serve. Enfim, este discurso toma para si a história: a continuidade e o progresso; produz as referências do passado, mostra, no presente, os sinais da obra de gerações antigas; aponta no futuro as últimas benfeitorias da evolução. (LT, [1976a] 2007, p. 290)

A regra, portanto, constitui-se como um potente corpo de prescrição a fornecer aos sujeitos sociais a segurança de um ordenamento do social e de uma inteligibilidade de suas relações, pois é condição do saber e do agir. Mas a regra enquanto ideia, para que possa produzir um encadeamento inteligível dos fatos, deve exibir-se como discurso, deve "tornar sensível sua essência de discurso" (FH, [1974] 1979b, p. 326) e, com isto, encontra-se desnivelado com relação ao poder. $\mathrm{O}$ discurso sobre o social afirma-se, então, como discurso impessoal, pois veicula um saber que parece oriundo da ordem das coisas, na trilha de uma ilusão que perpassa a sociedade moderna, uma vez que nela o real passou a ser suposto como racional, idêntico e identificável.

A ideologia burguesa dá a entender que o real é o que é, ou seja, que tudo o que é falado no discurso corresponde ao que as coisas são de fato, vistas como transparentes aos olhos de todos. Isto explica o seu caráter tautológico, pois a ideologia afirma o que a todos parece ser o próprio real, a verdade do real ou, ainda, aquilo que está colocado no real, exprimindo a mesma ideia, mas de maneiras diferentes. Chauí ([1977] 2011) esclarece que a ideologia

[...] promove uma certa noção de racionalidade, cuja peculiaridade consiste em permitir a suposição de que as representações e as normas estão colocadas no real, são o próprio real e a verdade do real. Assim, há uma dupla pretensão na ideologia: por um lado, procura fazer com que o discurso sobre as coisas seja um discurso que coincida com as próprias coisas e para isso, por outro lado, precisa afirmar que as coisas são racionais, que a racionalidade está inscrita no próprio real e que o trabalho do pensamento é apenas o de redescobrir esta racionalidade já inscrita no mundo. (CHAUÍ, [1977] 2011, p. 41)

Torna-se significativo, então, que a racionalidade que sustenta a ideologia nos remeta ao saber científico e à sua relação com a objetividade, pois nesta imbricação, verificamos que a ideologia está muito próxima da ciência na contemporaneidade. Ao considerar-se a racionalidade do real como ideológica, é importante salientar que não se 
está negando esta racionalidade e que afirmá-la não implica uma postura ideológica. A autora procura discutir o que a ciência passou a compreender como racional e em que sentido isto se vincula à ideologia. Nesse sentido, a ciência coloca-se como a outra face da ideologia, pois se afirma como aquela que tem a última palavra sobre o que vem a ser o real, que, objetivamente considerado pela ciência ${ }^{84}$, é tido como racional e transparente, pois, para o conhecimento científico, basta "apenas aprimorar os procedimentos científicos, melhorar as metodologias, melhorar o aparelhamento tecnológico, para que se chegue a essa racionalidade total que é a própria realidade." (CHAUÍ, [1977] 2011, p. 43). Sendo assim, a ciência alcançou o direito de explicação sobre todo o real e também é depositária de nossa confiança e garantia de uma segurança sobre a inteligibilidade do mundo. Essa confiança cega e essa busca incessante e sempre refeita - por intermédio de seus métodos e procedimentos - para abarcar e tornar o real inteligível e transparente nos leva, então, à ideologia, porque ela também não se cansa de modificar seus enunciados para que eles se mantenham correspondentes ao real, dando a razão dos fatos e enunciando a lei do real ${ }^{85}$.

\subsection{A contradição da ideologia burguesa}

A força da ideologia burguesa está no fato de que se efetua à distância do poder, em todos os espaços sociais, em todas as esferas e instituições como disjunção de discurso, isto é, como um discurso que se apresenta como tal, procurando sempre rearranjar seus enunciados para manter a eficácia de sua representação do real, tendo em vista que se estabelece na sociedade histórica e que esta, por sua vez, é marcada por transformações constantes, por acontecimentos que transformam as relações sociais. A ideologia burguesa está sempre se modificando para abarcar as questões que emergem em função da diferenciação do espaço social e dos conflitos de classe e de grupo.

\footnotetext{
${ }^{84}$ Conhecer é dominar o objeto que implica sempre no ponto de vista exterior daquele que o analisa, de tal maneira que se pode dizer tudo o que o objeto é, suas propriedades e o modo como elas se articulam. É por isso que a objetividade, de acordo com a filósofa, está vinculada à ideia de poder, uma vez que toda análise preocupa-se em esgotar teoricamente um objeto e, portanto, assumir a condição de dominá-lo inteiramente através das operações do intelecto (CHAUÍ, [1977] 2011, p. 45).

${ }^{85}$ Esta relação com a ciência é fundamental, pois ela nos dá um entendimento sobre a crítica que Lefort estabelece à ciência e à sociologia políticas, no momento em que as identifica como peças-chave na ideologia invisível que discutiremos mais adiante. Além disso, veremos, no quinto capítulo, que esta relação entre a ideologia e tais ciências nos remete ao pensamento do político que, não apenas se distingue delas segundo outra exigência de conhecimento, como também anuncia uma reflexão crítica da ideologia.
} 
Dessa maneira, seu discurso pode conter deslocamentos e, até mesmo, uma reviravolta em seus enunciados para abarcar aquela diferenciação e, assim, manter-se capaz de garantir a homogeneização e a unificação no implícito, pela justificação dos papéis sociais e da hierarquia social. Neste movimento interno da ideologia, identificamos também sua fraqueza, visto que acaba se constituindo como um discurso heteróclito, composto por referenciais, por justificações díspares que podem se contradizer mutuamente. Em função de seus antagonismos, pode haver um afastamento entre o social e o discurso, tornando sensível a instabilidade da ordem que procura recobrir.

O discurso recobre representações incompossíveis, vive de uma 'horrível mistura' entre a imagem de um indivíduo incondicionado e a de uma sociedade incondicionada, da aliança de um pensamento artificialista e mecanicista com um pensamento substancialista e organicista, e porque lhe é essencial explicitar-se como discurso sobre o social, porque não cessa de denominar as coisas, cria, a despeito de si mesmo, pelo efeito de suas discordâncias internas, o afastamento entre o social e o discurso. (FH, [1974] 1979b, p. 321)

A eficácia da ideologia burguesa depende de sua validade no cotidiano das relações sociais, ou seja, passa pela prova de sua validade no uso, permanecendo submetida à demonstração de sua eficácia. Para tanto, ela é capaz de transformar-se, recriando seus enunciados que permanecem sujeitos à contradição, explicitando-se como discurso sobre o social.

A ideologia burguesa é um discurso vulnerável, porque precisa sempre tornar visível o lugar de onde a relação social seria concebível, pensável e engendrável. Assim, a ideologia é minada por seu caráter transcendente, pois, diferentemente do discurso mítico, que, no momento em que é reenviado ao ponto de origem do qual se extraía a ordem de seus enunciados, permanece justificado e legitimado por um saber incontestável - mítico e religioso -, o discurso ideológico retrai-se rumo a um ponto de certeza, fala do alto pela transcendência das ideias, mas quando precisa atestar sua origem, seu fundamento, reenviando ao social, se expõe como discurso. É por isso que, havendo uma vacilação das certezas, em virtude de certas transformações transcorridas no social, a ideologia se vê ameaçada. 
[...] esse discurso, em seu projeto de extrair-se do social e de afirmar-se como discurso, só pode permanecer esparso e por que, na tarefa de generalização implícita do saber e homogeneização implícita da experiência, arrisca-se a esfacelar-se diante da experiência insuportável de uma ruína da certeza, de uma vacilação das figuras do discurso e, em consequência, de uma fragmentação do sujeito. (FH, [1974] 1979b, p. 325)

Assim, na ideologia burguesa, há sempre a possibilidade de que ocorra a percepção de sua disjunção com relação ao real, pois, em virtude do redobro que estabelece, a ideologia burguesa precisa sempre ser atestada pelo suposto real, senão corre o risco de perder sua eficácia, já que a regra deve passar pela prova de sua validade no uso e ficar submetida à demonstração de sua eficácia. A certeza esparsa, produzida em diversos lugares e, ao mesmo tempo, sempre sujeita a se refazer, a se recompor com a mudança no real - em virtude de crises, guerras, conflitos, etc - está sujeita a conter antagonismos, hiatos, brechas, lacunas, pois não consegue dizer tudo, afirmar e determinar tudo.

Nessa perspectiva, a racionalidade da ideologia burguesa está sempre sujeita a ser destruída, porque suscita um contradiscurso em cada um de seus registros, em cada esfera da sociedade, pois, "não há uma única ideia que não contenha outra que a contradiga" (FH, [1974] 1979b, p. 321).

\section{A ideologia totalitária}

Iniciamos nossa exposição sobre esta ideologia pela afirmação de Lefort de que a contradição da ideologia burguesa se reflete na ideologia totalitária (cf. FH, [1974] 1979b, p. 325). O que isto quer dizer?

Trata-se de um retorno do discurso ideológico sobre ele mesmo em termos de pensamento refletido, com o intuito de superar aquelas contradições, no sentido de uma reflexão ${ }^{86}$ e no sentido da constituição de uma identidade, tendo como mira (como reflexo, como imagem) a si mesmo. Tal entendimento encontra-se na compreensão que assume Lefort, no sentido de caracterizar a ideologia como um discurso que não nasce

\footnotetext{
${ }^{86}$ Observamos que, no artigo de Lefort, "Esboço de uma gênese da ideologia moderna" (1974), Marilena Chauí traduz "se réfléchit" por "reflexiona" (cf. FH, [1974] 1979b, p. 325). Preferimos traduzir da seguinte forma: "O fenômeno do totalitarismo nos permite decifrar os traços específicos da ideologia burguesa. Isso porque, nele, se reflete sua contradição.” (FH, 1978a, p. 532-533). Dessa forma, evidenciase a relação entre as ideologias, a qual ocorre como imagem refletida na qual se busca a superação das contradições da ideologia vigente, dando nascimento a um novo discurso ideológico.
} 
do zero, mas tem um ponto de origem, ou melhor, uma gênese na contradição de seu próprio discurso. Isso significa que a ideologia totalitária surge na contradição da ideologia burguesa, de modo que seus enunciados nascem no bojo dos antagonismos internos desta ideologia, com vistas a superá-los.

Assim, considerando a ideologia burguesa, veremos que, enquanto nesta, há uma clivagem entre representação e real afirmando-se o poder da representação, na ideologia totalitária, há afirmação bruta da identidade da representação e do real, uma verdadeira condensação dos termos da contradição. Trata-se de um discurso implicado na prática e que investe em si mesmo um saber geral, afirmando-se como inscrito no real e não mais, como na ideologia burguesa, a distância, em maiúsculas. Há afirmação da identidade do real segundo um saber que se supõe como real e não como representação do real, ou, em outras palavras, enquanto o discurso da ideologia burguesa faz questão de aparecer como discurso, em tornar sensível esta essência e permanecer desnivelado com relação ao poder, o discurso totalitário "se desdobra na convicção de estar impresso na realidade" (FH, [1974] 1979b, p. 326). É um discurso que não mais se exibe como discurso sobre o social, como ocorria na ideologia burguesa que mostra a posição daqueles que o falam - a classe dominante -, mas vai “imergir no social” (LT, [1981c] 2007, p. 433).

Dessa maneira, ele "encarna" a virtualidade de um domínio geral sobre as articulações de seus enunciados na prática social, generalizando o saber de como os indivíduos devem agir e pensar em toda a sociedade. Para tanto, apaga-se a divisão entre setores anteriormente reconhecidos na ideologia burguesa - político, econômico, estético, pedagógico -, de modo a propagar um só saber e uma só verdade válida para todos. Ao mesmo tempo, as oposições assumidas no âmbito do discurso da ideologia burguesa, em que é possível legitimar a posição do dominante e do dominado, nas relações entretidas em cada esfera - econômica, política, na instituição familiar - vêm a ser denegadas na ideologia totalitária. Desta forma, todos os conflitos engendrados em função das oposições próprias da sociedade burguesa são anulados e o antagonismo torna-se invisível. A divisão, portanto, não é considerada mais como constitutiva da sociedade, embora assuma uma nova figura: a de uma divisão externa, pois o corpo político requer a imagem de um inimigo, do outro para manter-se em sua unidade.

Em tal regime a divisão não parece mais constitutiva da sociedade; toma a figura de uma divisão externa que separa a verdadeira sociedade, o povo, o proletariado 
soviético de seus inimigos, isto é, das classes que obtêm sua existência e sua potência de um sistema estrangeiro - o despótico-feudal da época dos tzares ou o do capitalismo internacional. O princípio de uma divisão, de uma alteridade internas é abolido enquanto o outro se vê lançado para fora. Os próprios camponeses perseguidos, como todos aqueles sobre quem se abate a repressão, são qualificados, sejam quais forem os motivos do poder, como representantes desse outro. A intolerância absoluta para com toda forma de associação, de solidariedade, de expressão que testemunhe iniciativas coletivas ou individuais independentes, ao mesmo tempo em que é o indício de uma vulgar vontade de dominação por parte do Senhor e da burocracia dirigente, carrega assim a marca de uma construção ideológica. Por um lado, a sujeição do conjunto da população às normas e aos regulamentos do poder, a operação de nivelamento que este conduz; por outro lado, a afirmação de uma sociedade consagrada a se relacionar consigo mesma em todas as suas partes, a combinar numa mesma marcha os movimentos de seus membros, coletividades e indivíduos, e a falar uma mesma linguagem: esses dois fenômenos são indissociáveis. (ID, [1980d] 1983a, p. 102, grifos do autor)

Assim, as divisões internas são denegadas, embora não sejam destruídas completamente, pois uma burocracia destaca-se da população como nova camada e nova classe dominante, novas hierarquias e novas desigualdades e novas oposições de interesses se constituem. Para Lefort,

O paradoxo é o seguinte: a divisão é denegada - digo denegada já que uma nova camada dominante se distingue ativamente, já que um aparelho de Estado se destaca da sociedade - e, na medida dessa denegação, se vê fantasticamente afirmada a divisão entre o povo-Uno e o Outro. Esse outro é o representante das forças provenientes da antiga sociedade (kulaks, burguesia) e é o emissário do estrangeiro, do mundo imperialista (ID, [1979a] 1983a, p. 112-113).

Dessa maneira, há uma recusa, uma negação da divisão interna e afirmação de uma divisão externa, possibilitadas pelo recobrimento e invisibilidade da primeira e da afirmação constante da segunda para que a sociedade assuma sua identidade una pelo destacamento do Outro que é sempre potência de desordem.

Como esboçado anteriormente, na ideologia burguesa, existe a produção de uma trama discursiva que é o resultado de vários discursos produzidos em diferentes esferas, engendrando tipos de alienação em função das diferenciações próprias da sociedade capitalista. Cada esfera aplica suas próprias normas, originando alienações. Assim, ela condensa discursos sociais dominantes que se formam em função da diferenciação de atividades e de relações. No totalitarismo, ela implica o inverso: toda esfera aplica uma só e mesma norma; ela nasce da tentativa de condensar num mesmo discurso, de condensar numa mesma representação os elementos dispersos da certeza 
burguesa. Com isto, ocorre um processo de unificação, condensação que modifica a certeza e a torna indestrutível (imperforable), fora dos ataques do real, pois

Qual é o fundamento da conduta comunista, qual é a força (aos olhos mesmos de Soljenitsin: que se pese os termos de sua conclusão) que os preserva dos ataques do tempo, do real? A certeza. Uma verdadeira paixão que anula até os efeitos do sofrimento. Mas qual certeza? Aquela que porta sobre o todo da sociedade, que é encarnada num órgão condensando nele este todo, o Partido, e que converte cada militante em homem total. Uma certeza que pode se nutrir de todos os argumentos, que queima toda lenha, ignora a contradição... Se o Grande Saber não se deixa consumir pela prova dos campos, é porque aqueles que foram presos estavam desde já nele, que ele construiu uma fortaleza impenetrável. Eles não tiveram, então, que restaurar suas muralhas, eles passaram de um universo ao outro sem sair de seu recinto. (HT, [1976c] 1976b, p. 170-171)

É por isso que Lefort a considera como uma ideologia de granito (HT, [1976c] 1976b, p. 203), segundo a acepção de Soljenitsin, pois o processo ideológico provém de um único lugar, que tende a fazer coincidir o discurso social dominante com o discurso do poder, um fenômeno que, para Lefort, jamais se produziu anteriormente.

Este lugar único pode ser melhor compreendido se atentarmos para o que havia de específico na ideologia burguesa: um desnivelamento de seu discurso em relação ao poder, de modo que havia diversas verdades sobre a identidade do sujeito, assim como uma miríade de relações de dominação e subordinação em cada esfera da sociedade. Na ideologia totalitária, há uma mudança significativa, no sentido de que seu discurso torna-se, de ponta a ponta, político. Dessa maneira, aquele desnivelamento deixa de existir para dar lugar a um discurso que se encarna no poder, propagando-se e inscrevendo-se nos sujeitos sociais, de modo que tudo se torna político. O poder é apanhado na ideologia, de tal forma que se afirma o poder do discurso. Este, por sua vez, propaga uma verdade identificada pelos sujeitos sociais como a verdade do poder.

No totalitarismo afirma-se o que Lefort compreende como um "poder do discurso como tal" (LT, [1981c] 2007, p. 433), fazendo com que o discurso verdadeiro seja o discurso do poder que submete seus agentes, passa através deles, imprimindo-os em um saber impessoal que os subtrai à experiência dos outros e das coisas. Assim, este discurso acaba

[...] difundindo-se nos circuitos da socialização, elaborando sistemas de signos cuja função representativa já não é mais assinalável, apossando-se dos atores para inscrevêlos nestes sistemas, de tal sorte que o discurso fala (quase) através deles e (quase) 
abole o espaço, certamente indeterminado, mas sempre preservado pela ideologia burguesa, entre enunciação e enunciado. (FH, [1974] 1979b, p. 327)

O discurso totalitário, portanto, apaga as oposições características da sociedade burguesa, em especial, aquela entre Estado e sociedade civil. Ele difunde, em todos os lugares da sociedade totalitária as mesmas representações, reduz a um denominador comum os discursos parciais e múltiplos, fazendo-se total, excluindo a contradição. Estamos diante do processo de totalização que transforma profundamente a ideologia burguesa que, como vimos, exprime-se em múltiplas linguagens em espaços fragmentados em esferas política, econômica, jurídica, cultural, de forma a unificá-los e a recolocar sob as mesmas normas toda a representação social.

Nessa perspectiva, consideramos que este discurso ideológico é emitido a partir de um único lugar: do poder político, encarnado na pessoa do Egocrata e no Partido ${ }^{87}$, órgão por excelência do totalitarismo que figura a unidade, simula a lógica da reciprocidade das decisões políticas, assim como uma homogeneidade do corpo político. É a partir dele, como lugar do poder e como expressão da autoridade do Estado, que os indivíduos podem ser informados sobre a diversidade de suas atividades pela lógica da norma, sendo também contidos por uma submissão comum.

O partido de massa é o órgão por excelência do totalitarismo. Graças a ele, manifestase a consubstancialidade do Estado e da sociedade civil; encarna em todo lugar o princípio do poder; propaga a norma geral que fornece a segurança de uma espécie de reflexão da sociedade sobre si mesma e, simultaneamente, de sua polarização rumo a um alvo, liberando-se da surda ameaça da inércia do instituído, tornando sensível sua identidade sob o imperativo do ativismo. (FH, [1974] 1979b, p. 327)

O partido condensa o poder, a lei e o saber, ou seja, os fundamentos últimos e os fins de ordenanção da sociedade totalitária. Nesse sentido, ele é responsável por deter um mecanismo de identificação sem precedentes, ou seja, ele não pode ser compreendido simplesmente como Partido único, porque, enquanto Partido totalitário, tem a pretensão de uma incorporação total do social. Dessa forma, cada um, cada sujeito é suposto como aquele que encarna a verdade do partido. Como afirmamos acima o discurso da ideologia totalitária se dá como impessoal, como "discurso de ninguém”,

\footnotetext{
${ }^{87}$ A visão que tem Lefort sobre o partido, ao compreendê-lo como o lugar em que a ideologia se recolhe para ser produzida e propagada no totalitarismo, em termos de uma única verdade sobre o social, já está anunciada em seus estudos dos anos 1950, conforme salientamos no primeiro capítulo, em especial no artigo "Le totalitarisme sans Stalin" (cf. EL, [1956] 1979c).
} 
como "discurso do partido", "corpo ideal revolucionário que passa através de cada um de seus membros" (ID, [1979a] 1983a, p. 112). Assim, existe a afirmação de um nós que confere à sociedade totalitária a imagem de um corpo uno e homogêneo. Trata-se do "nós comunista", afirmado pelo Partido ${ }^{88}$ e de seu dirigente supremo que não diz "eu", mas "nosso partido", a tal ponto que Stalin pode dizer: "A sociedade sou eu" (ID, [1980a] 1983a, p. 72) ${ }^{89}$. Nesse sentido, temos a sociedade como Um, como um corpo totalmente político que nos leva a uma inversão da identificação clássica operada entre o príncipe e o Estado no despotismo.

Importante, então, vem a ser para Lefort a figura do militante, pois ele é um tipo novo de agente social, sua identidade confunde-se com o povo, o proletariado, o partido, estando incorporado nele e, portanto, dissolvido no "nós comunista". Na sua figura pode-se ver a inscrição do sujeito no discurso que se supõe falado por ele. Ele é o que mantém a máquina totalitária funcionando, como peça fundamental e, ao mesmo tempo, ocupa a posição daquele que nomeia e enxerga tudo, enquanto organizador, ativista e mobilizador das massas.

Ora, o tipo do militante simplesmente leva à expressão consumada a tentativa para apagar a diferença do indivíduo e da sociedade, do particular e do geral, do privado e do público. A imagem princeps é a do homem sem determinação que encontra sua definição como homem fascista ou como homem comunista: um puro agente social cujo pertencimento a uma classe ou é visto apenas como fornecendo uma modalidade acidental de sua inserção na sociedade total ou, então, é mesmo expressamente recusado pela pura denegação de uma cisão interna dessa sociedade. (FH, [1974] 1979b, p. 328)

O comunismo e o socialismo, na ótica de Lefort, portanto, na afirmação do "nós comunistas" e do "nós socialistas", contêm uma lógica da identificação cuja mola é a anulação dos conflitos que se engendram na sociedade burguesa. Ao fazer isso, tem o

\footnotetext{
${ }^{88}$ Obviamente, Lefort considera que o partido é dotado de divisões internas, de clivagens entre setores de atividade, compartimentações, hierarquias, mas considera que "elas estão dissimuladas sob a representação da unidade do partido, ou seja, sob o "nós comunista"' (ID, [1980d] 1983a, p. 103).

${ }^{89}$ Lefort cita em uma entrevista um episódio que lhe pareceu singular. Ao assistir um documentário sobre Stalin na televisão, ele visualiza o espetáculo encenado pelo partido e o jogo de engolfamento do chefe e daqueles que o escutam, no momento em que aquele dirigente fala às massas. Apesar de ser uma experiência vivida em 1996, Lefort a localiza no quadro de seu entendimento sobre o partido: "Eu me lembro de uma reportagem sobre Stalin, vista há pouco tempo na televisão. Ele se dirige a um imenso público de quadros, engrena frases curtas, se interrompendo após cada uma, para beber um gole de água, e repetir incansavelmente: 'nós somos orgulhosos de pertencer ao partido de Lênin'. O espetáculo é burlesco. Nada trai sua onipotência, senão que, a cada minuto, a sala se abate sob os aplausos. Seja qual for a parte do jogo, importa que o partido pareça englobar o chefe e aqueles que o escutam. Stalin é o mestre, mostrando-se a criatura do partido de Lênin. Eu acrescento que ele tem qualquer coisa de um ser mítico.” (LT, [1996] 2007, p. 847)
} 
efeito de dissolver "as linhas de clivagem entre dominantes e dominados na imagem de uma hierarquia puramente funcional, onde cada membro estaria ligado gradativamente ao núcleo central da socialização”. (FH, [1974] 1979b, p. 328)

Falaremos, ainda, sobre a representação da organização ${ }^{90}$. A existência de organismos de massa no totalitarismo - sindicatos, agrupamentos de auxílio mútuo, agrupamentos culturais de trabalhadores de diversas categorias, organizações de jovens, de crianças, de mulheres, círculos de escritores, de artistas, de cientistas, academias -, combinados com o partido, potencializam o processo de identificação entre o poder e o povo e do processo de homogeneização do campo social, na medida em que circulam as normas comunistas. Estes diversos microcorpos, simulando a distinção de uns para com os outros e, portanto, a especificidade e a autonomia de relações que se dão como puramente sociais, contribuem para que a sociedade seja concebida como matéria amorfa organizada e organizável, em que o estatuto e a função dos indivíduos são previamente estabelecidos.

Esta representação também nos remete à vigência de uma busca constante pela garantia da integridade do corpo, pois a ideia de organização supõe a ideia de uma desorganização, de um caos, sempre ameaçadores, responsáveis por perturbar e sabotar a lei socialista. Dessa maneira, mais uma vez, o outro, o inimigo que é erigido como inimigo do povo encontra-se sob a necessária profilaxia social, pois, para que o corpo permaneça íntegro, torna-se necessário eliminar seus parasitas. (cf. ID, [1980a] 1983a, p. 84)

Se tomarmos os processos de Moscou de 1936 a 1938, teremos mais esclarecimentos sobre estas questões, uma vez que eles nos permitem compreender a significância deste saber incrustado no partido que passa por meio de seus militantes e que recusa todos àqueles que venham a falar uma linguagem que destoa da linguagem socialista ou comunista. Tomamos como exemplo o caso de Bukharin, teórico marxista julgado e executado, que não pôde se livrar deste nós fantástico encarnado em sua pessoa. Em seu julgamento, produziu-se um diálogo entre procurador e acusado que ilustra muito bem este nós, pois ambos - procurador e acusado - compõem este nós, uma vez que são comunistas. Assim, está vetada a possibilidade do acusado falar em sua própria voz, de se descolar do discurso que o engloba e, no julgamento, o engloba ainda

\footnotetext{
${ }^{90}$ A representação da organização também está presente na ideologia invisível.
} 
mais arrasando-o. O rótulo atribuído a Bukharin de opositor do Partido advém da representação daquele nós como peça mestre da teoria. Em certa medida, o opositor não pode verdadeiramente se opor, porque ele sacrificaria, assumindo o risco de sua exclusão, a ideia segundo a qual o Partido dirige o processo revolucionário. Tal é, então, sua tragédia: intelectual. $O$ opositor não pode ser nem a favor nem contra a direção do poder, pois o partido detém a verdade última sobre todas as coisas. Assim, na defesa de Bukharin, ele permanece sem voz; precisa falar pela boca de Vichynski (seu acusador), pois, para se defender e se voltar contra seus acusadores, precisa mobilizar um saber que pertence ao Partido, pois Bukharin não pode dispor de um saber fora do Partido ${ }^{91}$. Desta forma, compreendemos o quanto, no totalitarismo, o Partido tem sempre razão, pois não se pode ter razão a não ser com e para o Partido. Esteja certo ou errado, a verdade suprema pertence ao Partido (cf. HT, [1976c] 1976b, p. 144)

$\mathrm{Na}$ linha ainda desta reflexão sobre o exercício do saber como certeza na ideologia totalitária, gostaríamos de evocar uma discussão desenvolvida por Lefort sobre os "bem pensantes", uma expressão utilizada por Soljenitsin em um dos capítulos de sua obra $O$ Arquipélago Gulag (1975). Trata-se deste "saber comunista" que figura naqueles "bem-pensantes", que são, na verdade, ortodoxos que falam e agem segundo um respeito incondicional a um dogma, como se fossem membros de uma igreja ou de uma seita religiosa. Seguindo Soljenitsin, Lefort discute aqueles que estabeleciam convicções ideológicas, pessoas que estavam na instrução e na direção dos campos de concentração em que havia desertores do regime comunista. Para eles, não se tratava somente de pensar corretamente, na linha do Partido, mas de assumir-se como "criatura do bem pensar" (HT, [1976c] 1976b, p. 161). Uma categoria singular de homens estetas, celebrando a linguagem e a retórica, para discorrer sobre todas as coisas, muito próximo daquilo que evocou Sócrates, quando considerou que nada poderia estar fora do "bem-dizer". Para Lefort, no entanto, há um remanejamento no totalitarismo em que "mais eficaz é a lei do bem-pensar que aquela do bem-dizer para garantir o comando: não pensar”. (ibid., p. 161)

\footnotetext{
${ }^{91}$ Vemos, portanto, a grande dificuldade para se mobilizar um contradiscurso à ideologia totalitária. Exemplarmente, neste julgamento, qualquer argumento mobilizado, para que faça sentido, para que seja da ordem do inteligível, precisa constituir enunciados que detenham os mesmos signos do discurso do partido.
} 
O traço característico deste "bem-pensar" é a exibição, um modo eminente de narcisismo ${ }^{92}$. Os "bem-pensantes" procuram mostrar que pensam bem, afirmam sua superioridade de detentores do saber. Eles se mostram uns aos outros distantes dos estrangeiros. Eles se reconhecem mutuamente como membros de uma elite intelectual. E, ao mesmo tempo, ainda, deixam exibir-se através deles o grande saber do Partido, o qual se reflete em cada um, tornando-os seres puros como de cristal através do qual este saber passa; são belos pensamentos. (cf. HT, [1976c] 1976b, p. 162)

É importante notar que o saber comunista tal como trabalhado no discurso ideológico pelo exercício da propaganda no rádio e nos jornais, não tem o objetivo de persuadir, nem mesmo a serviço da conquista, nem da conservação do poder, mas de se manter como algo indispensável para suprimir, engolir o Outro, ao mesmo tempo em que se reenvia a si mesmo. Assim, torna-se possível tornar manifestos os signos de absorção do social, no discurso do Partido e de sua toda-potência, capaz de conferir uma identidade coletiva.

Este discurso é uma maneira de suprimir, de engolir o Outro; e, simultaneamente, é uma exibição comunista. Que o discurso não vise a outra coisa, senão reenviar a ele mesmo (...). (HT, [1976c] 1976b, p. 164)

O discurso típico da ideologia totalitária é aquele falado por militantes comunistas, seja no interior do próprio regime, seja em outros lugares onde esta militância se faça presente, como na França, na época em que escreve Lefort. O diálogo que estes militantes travam entre si pode ser definido como uma "discussão única", pois é como se os homens estivessem fundidos uns aos outros, pois pouco importa o conteúdo deste diálogo - a miséria nas cidades, a penúria dos produtos de primeira necessidade, o salário dos trabalhadores, o crescimento da delinquência juvenil, a repressão - qualquer deficiência apontada como existente no regime é sempre justificada como "erros e desvios que dão razão ao reforço da educação socialista", "são testemunhos falsos", "é apenas efeito do burocratismo local", "é fato não generalizável", etc. Este discurso, portanto, se ativa sob o signo do "não pensar" (cf. HT, [1976c] 1976b, p. 171). Este, por sua vez, se apossa de todos os signos que, no diálogo, na fala, poderiam colocar em falta a composição comunista, seja para recusá-

92 Este caráter exibicionista referido aos "bem pensantes", conforme veremos, também se repete na ideologia invisível, em que o discurso ideológico é tomado por um vertiginoso amor de si, propagando-se indefinidamente como discurso que fala sobre tudo e que tem no discurso técnico-científico sua principal expressão. 
los, seja para refleti-los como simples acidentes, seja também para compreendê-los como algo que transcende a ordem dos fatos. Dessa maneira, tudo é reduzido ao "já pensado", ou seja, o mundo como um todo é afirmado como algo inescapável ao traçado de seus arquitetos. Assim, qualquer acontecimento não é suscetível de fazer vacilar o discurso ideológico, pois tende a ser considerado como algo da ordem do "já pensado".

De fato, o mundo a que visa este discurso - e que não deixa de clamar - só é pensável na medida em que se quer transformá-lo; a palavra, o pensamento comunistas são feitos para liberar a figura do novo... Mas este novo é rigorosamente destinado ao estatuto da prova do já pensado. Percebido como um vasto canteiro onde se edifica o socialismo, o mundo se vê simultaneamente reduzido à representação de seus supostos arquitetos. Aparentemente, se venera a História; mas, em verdade, é o contrário: o desejo se apega a uma sociedade sem história, uma sociedade na qual toda indeterminação seria banida, em que o efeito do acontecimento é desmantelado de antemão, em que o desconhecido por princípio não excede os limites do conhecido. (HT, [1976c] 1976b, p.172, grifos do autor)

Consideremos, por fim, o papel do comunismo, enquanto conhecimento de ordem transcendente, na ideologia totalitária. Vimos que ele é detido por uma elite que está encarregada de pensar, mas que toda a verdade que busca realoca-se no plano do já pensado, do já descoberto e, com isso, se afirma o "não pensar". Esta operação de conhecimento, por sua vez, torna-se inteligível quando compreendemos que estes "bem pensantes" são aqueles apontados por Lefort, seguindo Harold Rosenberg, como os "heróis da ciência marxista". Assim, estamos diante de um novo comportamento intelectual que se alia àquela transcendência, na medida em que a teoria marxista enuncia o verdadeiro e o real, ou melhor, que reflete a verdade que está impressa nas coisas, estabelecendo uma relação entre o sujeito e o suposto objeto, a qual se instala em um universo que é "todo visível”, "todo inteligível” (cf. HT, [1976c] 1976b, p. 175), e, da mesma forma, anula em si mesmo a necessidade de ver e de pensar.

A transparência do real e o seu pleno entendimento conjugam-se na forma de um novo gênero de ocultação que é exercido pelo saber, ele mesmo. Lefort o considera como luz ofuscante (lumière aveuglante). Nesse sentido, compreendemos que a "ciência marxista", enquanto representação da teoria de Marx, forjada no processo da interpretação de sua obra, implica no apagamento daquilo que constitui o caráter instituinte de seu pensamento, pois retira o caráter indeterminado ${ }^{93}$ da teoria para

\footnotetext{
${ }^{93}$ Lefort afirma que, nas leituras de militantes comunistas como interpretações da obra de Marx, ocorre uma denegação de diversos elementos presentes na obra que têm o efeito, justamente, de "dar a pensar" e
} 
permanecer como discurso fundador, como "discurso oficial" do comunismo. (cf. HT, [1976c] 1976b, p. 177) Dessa maneira, não se trata de imputar a Marx um papel chave na edificação da ideologia de granito, mas sim à representação de sua obra feitas por Lenin, Stalin, pela intelectualidade militante comunista em geral, a qual se apropria da lógica da ciência marxista. Nesse sentido, eles se servem da teoria como textos sagrados, como Escrituras que oferecem a verdade impressa nas coisas.

Para eles, o real é transparente por direito, o sentido se lê nos fatos, a teoria da qual eles se reclamam é do mesmo modo transparente; seu sentido se dá por direito a quem faz o esforço de aprender. Da realidade à teoria, como da teoria à realidade, a passagem é sempre evidente. Trata-se apenas de uma passagem: eles estão sob a mesma luz. Se Marx, Engels, Lénin têm lugar como textos sagrados, o mistério não tem aqui lugar. Assim, que as Escrituras revelam ao esconder, convocam a uma exegése, o marxismo anuncia o verdadeiro sobre o verdadeiro, ou, como se poderia dizer, reflete a verdade impressa nas coisas. E, simultaneamente, a transparência se acompanha de uma ocultação de um gênero novo exercido pelo saber ele mesmo, luz ofuscante desde que seja realizado. (HT, [1976c] 1976b, p. 174-175)

Não devemos nos enganar, no entanto, em considerar que teria havido pura e simplesmente uma deformação das ideias de Marx, pois poderíamos permanecer em uma discussão em torno de uma história das ideias e sua relação com as circunstâncias responsáveis por produzir aquela alteração, sem questionar o seu papel, como saber, no discurso do poder responsável por nomear e incorporar a ordem social. Devemos, sim, reconhecer qual é o trabalho de interpretação ${ }^{94}$ de um pensamento realizado pela ideologia: é justamente o de recobrir, sob palavras que parecem saídas da boca do autor, a realidade. Elas são deslocadas do lugar em que foram cunhadas e articuladas por ele para se inserirem em um novo discurso - o discurso ideológico ${ }^{95}$.

que, portanto, não desembocariam na ideologia. Ele se refere a algumas ideias que foram extraídas da obra de Marx como a ideia de ditadura do proletariado, à qual foi conferida uma positividade, omitindo-se a crítica à burocracia de Estado apontada por Marx no fim de sua vida; a ideia de abolição da propriedade privada que foi separada da crítica do modo de produção que desvendaria a concentração crescente do capital e que pode ser colocada contra o sistema soviético. Dessa maneira, Lefort considera que da obra de Marx foram extraídos enunciados que, deslocados do movimento da reflexão do autor, perdem o sentido que haviam conquistado no jogo das palavras, formando a articulação de seu pensamento, para se tornarem fórmulas prontas para serem aplicadas.

${ }^{94}$ No quinto capítulo, discutiremos a noção de interpretação e como ela pode se colocar a serviço da ideologia ou favorecer uma crítica à ela.

${ }^{95}$ Mas, não devemos esquecer também que a obra contém ambiguidades, favorecendo a ciência marxista, e, ao mesmo tempo, leituras como a que Lefort se propõe fazer, como pudemos explorar nas duas noções de história - shakespeariana e evolutiva -, discutidas por ele no artigo "Marx: de uma visão da história a outra" (FH, [1965] 1979b). 


\subsection{A contradição da ideologia totalitária}

A ideologia totalitária, em seu ultrapassamento das contradições da ideologia burguesa, não cessa de chocar-se com a impossibilidade de seu cumprimento, ou seja, o discurso da ideologia totalitária não se cumpre efetivamente, no sentido de que a divisão social continua a existir, mas é mascarada, o poder continua a ser detido pelos homens, mas é encarnado no Egocrata como representação do povo-Um, a burocracia compõe uma nova camada dominante e a desigualdade reina sob novas formas, o Partido se insere em toda a sociedade (nos gabinetes de trabalho, nas fábricas, em todos os setores da produção e da cultura) em que os referenciais da lei, do saber e do real podem ser denegados, mas não abolidos. Assim, embora a ideologia procure estabelecer todas essas denegações, ela está sujeita a aparecer como mentira, porque não pode abolir completamente todos os elementos de que é feita uma sociedade humana. Nesse sentido, as contestações emergem e podem desvendar a natureza deste discurso ideológico como "verdade suposta" sobre o social. Com relação ao totalitarismo, Lefort afirma que

Sua fantástica tentativa de apagar a divisão social, de tragar todos os processos de socialização no invólucro do Partido, de precipitar o simbólico no real, está exposta à ameaça de uma restituição violenta de todos os signos da divisão e da alteridade. $\mathrm{O}$ poder, que se dissimula, arrisca reaparecer como órgão de opressão, em sobrevoo sobre o conjunto da sociedade e de tornar-se alvo comum de toda contestação. O Partido, que penetra em todos os meios, exerce seu controle sobre todas as atividades, arrisca de se fazer ver por todos como parasita. A distância entre aqueles do alto e os de baixo e, mais geralmente, a desigualdade ameaçam de se mostrar a nu. Enfim, a ideologia invasora arrisca-se provocar uma recusa generalizada da crença, um modo radical de desafeição que a relega ao estatuto de pura mentira política,- o poder do discurso desmoronando para deixar sem grade protetora a imagem do poder opressor. (LT, [1981c] 2007, p. 434)

A ideologia totalitária arrisca-se a aparecer como lógica do absurdo, a incitar o terror, pois a contradição do totalitarismo encontra-se no fato de que nele o poder se mascara duplamente, enquanto representante da sociedade sem divisão e enquanto agente da racionalidade da organização, ao mesmo tempo em que se mostra, como em nenhuma outra sociedade, como aparelho de coerção e como portador da violência nua.

A afirmação do social total não o livra do fantasma da autodevoração; o discurso totalitário apaga a exterioridade da ideia; o discurso sobre o social tende a se reabsorver no discurso social, apaga a exterioridade do poder; o Estado tende a operar sua fusão com a sociedade civil, apaga a exterioridade da regra; a organização tende a bastar-se só por veicular a racionalidade, apaga a exterioridade do outro; a divisão 
social é dissimulada, mas a exterioridade retorna, o discurso fica ameaçado de aparecer como mentira generalizada, como discurso do poder, simples máscara da opressão. (FH, 1978a, p. 549, tradução nossa)

Para que a ideologia totalitária se torne efetiva, as posições de poder devem ser denegadas no interior da burocracia, ao mesmo tempo em que se dá a exclusão da massa dos sem poder dos aparelhos. Ainda que isso ocorra, pode haver um deslizamento das posições de poder, certa instabilidade como ocorreu após a era stalinista, no sistema de representações burocráticas, que tornava visível o mecanismo da dominação. Ao mesmo tempo, os acontecimentos também são fonte de instabilidade, pois testemunham um fracasso da norma geral, uma "falha" no funcionamento da organização burocrática.

Nestas situações, pode haver a crítica, como pode haver um novo comentário ideológico responsável por imprimir o acontecimento, a falha, na lógica da organização. Dá-se, dessa forma, a afirmação do "burocratismo" como o verdadeiro entrave, como doença da regulamentação, pela sua inércia e pelos seus agentes parasitários.

\section{A Ideologia invisível}

Nas democracias ocidentais, Lefort considera que há um novo discurso ideológico, o qual mantém uma relação estreita com a ideologia burguesa e com a totalitária. Veremos, primeiramente, que tipo de imbricação há entre elas para depois discutirmos o significado do atributo "invisível" conferido a esta ideologia.

Da mesma forma que a ideologia totalitária realiza uma "reflexão" sobre as contradições da ideologia burguesa, assim também ocorre com a ideologia invisível em relação à totalitária e à burguesa, sintetizada no trecho seguinte:

Recobrir a distância entre a representação e o real, distância perigosa para a ideologia burguesa, renunciar ao cumprimento da representação sob a forma de totalização do real, tal é, aos nossos olhos, o duplo princípio que ordena a nova lógica da dissimulação. (FH, [1974] 1979b, p. 335)

Este trecho sintetiza a ideia de que a ideologia invisível recobre a distância entre a representação e o real, mas também não produz a totalização do real, como ocorre na ideologia totalitária, isto é, a nova ideologia acolhe aquilo que subsiste da 
ideologia burguesa e que se prende à forma democrática de sociedade, a saber, a figuração das oposições, a contestação fixada sobre ideias, constituindo um resíduo ineliminável e absolutamente necessário à alimentação do diálogo. Mas, ao mesmo tempo, trata-se de um diálogo que se dá sob a fantasmagoria da reciprocidade, algo que não há no discurso da ideologia burguesa, de tal forma que o vínculo social ocorre longe da experiência de sua realidade, ressaltando a representação de uma ligação social inconsciente. Para compreendermos esta fantasmagoria, torna-se necessário explicitarmos a importância da dimensão imaginária da comunicação.

Na nova ideologia, tudo se mostra dizível, visível e inteligível, de tal forma que, em nenhuma outra época, falou-se tanto e sobre tudo: do desodorante ao problema da alta de preços, da emancipação da mulher à morte nas estradas, da saúde à música e à sexualidade, enfim, nada escapa dos programas televisivos, dos debates, dos colóquios, evidenciando que o discurso sobre o social encontra-se tomado por um "vertiginoso amor de si”. (FH, [1974] 1979b, p. 337)

Nessa lógica, o rádio, a televisão e, se pensarmos contemporaneamente, as redes sociais, destacam-se como meios privilegiados de propagação da nova ideologia. A mídia impressa, televisiva, radiofônica - e os efeitos da internet que estavam ausentes da ótica de Lefort - criam as condições para que o sujeito encontre-se (quase) alojado no sistema de representação, mas de um modo diferente daquele da ideologia totalitária. Ele acolhe os termos da oposição mencionados, cuja referência encontramos na ideologia burguesa e, ainda, encontra-se alojado no grupo ${ }^{96}$, sendo captado em toda parte no circuito da socialização.

Mas, não menos instrutiva, é a função exercida, nesse aspecto, pelos grandes órgãos que estão a seu serviço - o rádio e a televisão. Sem eles, o novo sistema de representação seria seguramente inviável, pois é por se propagar de um núcleo cada vez mais aparentemente circunscrito a um núcleo aparentemente indeterminado, é pelo efeito de sua réplica indefinidamente multiplicada do polo privado da instituição ao polo público da informação, que o discurso ideológico ganha a generalidade necessária à sua obra de homogeneização no implícito. (FH, 1978a, p. 552, tradução nossa)

\footnotetext{
${ }^{96}$ O grupo, para Lefort, representa um elemento inexistente no totalitarismo e que, na democracia, passa a figurar a impossibilidade da afirmação da totalidade. Ele se interpõe entre o aparelho de dominação e a massa dos sem-poder, criando as condições para que se estabeleça também uma nova fé: a de um "domínio" do social, justamente porque favorece uma socialização (política, sindical, religiosa) aqui e agora, isto é, nas fronteiras sensíveis de cada instituição - igrejas, empresas, escolas, universidades. (cf. FH, [1974] 1979b, p. 336)
} 
A imagem da reciprocidade é erigida como sendo a da própria relação social. São os meios de difusão midiáticos que nos oferecem a possibilidade de tudo dizer e, embora representem a impossibilidade de uma limitação da outorga da palavra como ocorrida na experiência totalitária, isso não quer dizer que se dê uma fala viva, uma fala do sujeito. O discurso veiculado explicita-se apenas parcialmente como discurso político, criando a sensação, pelo fato de tudo dizer, que a palavra circula sem obstáculos, dando a impressão de uma democracia consumada. Dá-se a encenação de debates, dissimulando-se os princípios de sua ordenação, difunde-se um conhecimento objetivo através da fala do informante que se coloca num polo anônimo e neutro - sem poder - absorvendo o elemento pessoal no discurso impessoal, criando a alucinação do próximo pela mídia, a qual subentende uma ligação social.

A encenação prossegue, assim, até tornar sensível a identidade dos atores. Temos aí, sem dúvida, uma das molas mais notáveis do imaginário: absorver o elemento pessoal no discurso impessoal que figura a essência da relação social, dando crédito a uma fala viva, uma fala do sujeito, quando, na verdade, esta fala é dissolvida na cerimônia da comunicação. Ficção, pois os limites do debate são fixados fora de seu campo visível, a neutralidade do condutor do jogo dissimula o princípio de sua ordenação e, enfim, os detentores do poder estão presentes no mesmo plano em que aqueles cuja sorte decidem nos bastidores. (FH, [1974] 1979b, p. 337)

Dessa maneira, dá-se o ocultamento da divisão pela grande ficção engendrada pela ideologia invisível que alimenta a "imagem de um discurso", por meio do qual tudo viria a transparecer, isto é, todos os assuntos tornam-se passíveis de um suposto questionamento, inclusive certos temas-tabu e aberta a possibilidade de todos falarem, uma vez que o contraditor é previsto como aquele que será responsável por manter o debate sob controle. Assim, a clausura do saber, representada na ideologia totalitária, não é mais necessária, pois neste último caso é preciso uma só verdade que se conserve no tempo, uma vez que o progresso do futuro estava remetido ao desenvolvimento do presente, enquanto que na ideologia invisível, como na burguesa, há verdades que são sempre refeitas. Na ideologia invisível, esta verdade é refeita a partir do novo - por exemplo, novas pesquisas científicas que revelam segredos sobre a natureza, sobre o homem, sobre a saúde - suscitando o fascínio pelo presente, pois o desconhecido é algo domesticado e dominável. Nesse sentido, tudo o que se apresenta como fonte de um novo sentido, tudo o que na política anuncia possíveis pelas contestações populares, por exemplo, apresenta-se cultivado pela ideologia, como algo circunscrito ao registro do 
conhecido. Assim, o histórico permanece figurado como tal por meio da fantasmagoria do novo, pois se constitui como um artifício da ideologia: é resultado, prova material de algo já antecipado no passado e concebido no presente e, portanto, de uma suposta diferença temporal sempre dominável ${ }^{97}$.

A noção entre-nós (entre-nous) é extremamente esclarecedora no que compete ao processo de socialização numa democracia em que há a ideologia invisível. Como duas faces inseparáveis, temos, por um lado, a palavra entre que nos remete a uma relação que acolhe os termos da divisão, da oposição entre o um e o outro; e, por outro lado, temos o nós que tem o efeito de camuflar aquela divisão e de subentender uma ligação primordial entre os sujeitos sociais. O nós é aquele que figura a unidade e é prometido à invulnerabilidade. Opera-se a representação da ligação social pelas ondas da comunicação. Os programas televisivos têm o efeito de reunir seus destinatários pela absurda proximidade com aquele que fala, seja como apresentador, como astro da novela ou como o novo "big brother", ele faz baixar a ilusória familiaridade, provocando a alucinação do próximo ${ }^{98}$. A certeza da comunicação ainda faz com que ela possa bastar-se a si mesma, uma vez que o sujeito ausentando-se, não deixa de estar em seu circuito, de modo que "pouco importa que pare de ver com seus olhos, ouvir com seus ouvidos, seu espectro (fantôme) pessoal está, de uma vez por todas, instalado no lugar entre-nós"99 (FH, [1974] 1979b, p. 338). Adquire pouca relevância o conteúdo que aparece entre-nós, pois o mais importante é o poder de subentender uma ligação primordial.

Como vimos, o discurso totalitário apresenta uma tendência a dissolver o elemento pessoal porque não suporta a imagem da dispersão de núcleos de socialização, nem o risco de uma experiência do sujeito num lugar particular que escape à norma geral. Tal dispersão encontra-se "sob controle" na ideologia que está presente na democracia, ela deixa de ser um risco para a integridade da representação do social, uma vez que o sujeito encontra-se captado em toda parte por sua própria imagem no circuito

\footnotetext{
${ }^{97}$ Veremos, no quinto capítulo, que a noção de possíveis, no pensamento de Lefort, está atrelada ao desejo, na linha de Maquiavel (2008) e La Boétie (1999), que põe em jogo a recusa do adquirido determinada forma de sociedade, suas instituições e a ideologia - sendo engendrador do histórico. Mas, para ter este efeito, precisa estar ligado à interrogação.

${ }_{98}$ É título de nota a reação de um telespectador ao se deparar na rua com um astro da televisão, abordando-o como se fossem grandes amigos.

${ }^{99}$ Novamente, a internet ilustra ainda mais essa perspectiva. Redes sociais como "facebook" demonstram que, na ausência de seus usuários, seu espectro pessoal continua lá instalado por meio de sua página pessoal. O sujeito, portanto, nunca deixa de estar inserido no circuito da comunicação.
} 
de socialização, a tela da televisão fornece a ilusão repetida de um entre-nós, que projeta uma relação social que se basta a si mesma e condensa a dupla representação de uma relação em si e uma relação entre pessoas. Assim, a encenação da comunicação possibilita uma ligação social inconsciente e a implicação do sujeito no grupo. Mas o nós não é afirmado e, sim, pressuposto, diferentemente da ideologia totalitária cuja referência é o "nós comunista" ou, da mesma forma, na democracia, em que porventura possa haver referência ao "nós, liberais", "nós, homens do progresso", ou "nós, socialistas", pois o que permanece é a compreensão do circuito no qual os agentes estão referenciados uns com relação aos outros. (cf. FH, [1974] 1979b, p. 339)

A tela da televisão nada mais faz do que materializar uma tela impalpável sobre a qual se projeta uma relação social que se basta em si mesma, enquanto condensa a dupla representação de uma relação em si e de uma relação entre pessoas. Que se meça, por exemplo, a eficácia do dispositivo que, das emissões de publicidade às emissões de política ou de cultura, fornece a ilusão repetida de um entre-nós. (FH, [1974] 1979b, p. 338)

Esta ilusão de um "tudo dizível” está relacionada à ciência, pois a eficácia da ideologia invisível depende da representação da cientificidade do discurso. Lefort afirma que essa representação encontra-se no coração da ideologia burguesa, embora nesta a ciência ainda figure como um "polo visível” (FH, [1974] 1979b, p. 340), enquanto no imaginário, promovido pela nova ideologia, o discurso ideológico e o discurso científico se fundem.

$\mathrm{Na}$ ideologia burguesa, ocorre a representação da cientificidade do discurso, pois há um discurso sobre a ciência, ao mesmo tempo em que a exploração da ciência na linguagem que discorre sobre o social. No quadro da produção industrial, por exemplo, o taylorismo oferece-nos uma expressão dessa lógica, em que se dá a aplicação da ciência no discurso que figura a lógica da produção como algo apropriado pelo dirigente e pelos executantes em seu trabalho cotidiano.

Nesta representação, portanto, a ciência mantém-se visível, enquanto, na ideologia invisível, ela não aparece mais como tal, mas torna-se encarnada no discurso ideológico, sendo dificilmente dissociável. Seguindo o exemplo da produção industrial, dá-se o imperativo da organização, a qual não é mais um objeto da ciência, uma aplicação dela, mas é diretamente regida como discurso científico, segundo imperativos racionais, em que, na divisão de funções, cada trabalhador responde a um agir 
prefigurado pelo discurso da organização enquanto absolutamente científico. Sua eficácia decorre do fato de não ser possível aos sujeitos perceberem que se trata de um discurso exterior, pois este é visto como a lei da organização, responsável por lhes ditar as marcas de sua identidade, convertendo-os em "homens da organização", extremamente racionais em todas as suas condutas, em todas as esferas da sociedade. Isto porque a lógica da organização perpassa todas elas: os grandes estabelecimentos sociais, firmas comerciais, nas administrações públicas e privadas, universidades, hospitais.

$\mathrm{Na}$ ideologia invisível, assim como nas ideologias anteriores, investe-se uma crença generalizada numa autointeligibilidade do real e numa autointeligibilidade do homem por meio da ciência. Assim, a magia da objetividade torna tudo dizível, inteligível no que diz respeito a todos os domínios, estando ancorada em um discurso científico, de modo que tudo é dito sob a forma de um "discurso competente", como interpretou Chauí ([1978] 2011). Partindo de Lefort, esta autora compreende que a nova ideologia vem a ser um discurso neutro da cientificidade ou do conhecimento, instaurado como lei da Organização, responsável por conter um conhecimento prévio sobre os sujeitos, as formas de suas ações e de cooperação "racionais", sempre sob o primado "da ilusão de que as coisas funcionam em si sob a direção de uma racionalidade que lhes é própria e independente da vontade e intervenção humanas". (CHAUÍ, [1978] 2011, p. 23).

O discurso competente é, então, o discurso do especialista, proferido de um ponto determinado da hierarquia organizacional, existindo em diversos lugares onde esta hierarquia estiver presente. Sob a capa da cientificidade, este discurso disfarça a existência real da dominação, inspirando-se na "suposta realidade dos fatos e na suposta eficácia dos meios de ação", segundo a interpretação de Chauí ([1978] 2011, p. 23). É por isso que todos os sujeitos sociais encontram-se sob o domínio da fala dos especialistas, ao mesmo tempo em que a reproduzem como sua própria fala, na ilusão de que detêm aquele saber que lhes garante o "bom vínculo social" (FH, [1974] 1979b, p. 343) - pois não saber significa não coincidir com o ser social - e sua correspondência com o tempo - uma vez que este tempo é demarcado e ditado pelo novo conhecimento científico oferecido indefinidamente e que se apresenta como a própria realidade humana. O especialista é o responsável por deter todas as respostas, de conhecer todos os segredos da natureza, do corpo humano, da política, a nos dizer como devemos criar 
nossos filhos, ensinar nossos alunos, nos relacionarmos com nosso próprio corpo - com nossa alimentação, nossa sexualidade - com nossos amigos e familiares, com o poder.

Lefort observa o papel desempenhado pela psicologia, sociologia e psicanálise na mídia. Ele afirma:

Parece uma tagalerice competente [bavardage savant], incessante, que vem ensinar a cada um isto que é a arte de bem viver, a arte da dietética, a arte de ensinar seus filhos, a arte de se comunicar com os outros, a arte de praticar a sexualidade (...) (LT, [1989] 2007, p. 638)

Chauí apoia-se em um trecho do artigo "Maintenant" (LT, [1976a] 2007) de Lefort para desenvolver esta ideia:

Como escreve Lefort, o homem passa a relacionar-se com a criança por meio do discurso pedagógico e pediátrico, com o lactente, por meio do discurso da puericultura, com a natureza, pela mediação do discurso ecológico, com os demais homens por meio do discurso da psicologia e da sociologia. Em uma palavra: o homem passa a relacionar-se com a vida, com seu corpo, com a natureza e com os demais seres humanos através de mil pequenos modelos científicos nos quais a dimensão propriamente humana da experiência desapareceu. Em seu lugar surgem milhares de artifícios mediadores e promotores de conhecimento que constrangem cada um e todos a se submeterem à linguagem do especialista que detém os segredos da realidade vivida e que, indulgentemente, permite ao não-especialista a ilusão de participar do saber. Esse discurso competente não exige uma submissão qualquer, mas algo profundo e sinistro: exige a interiorização de suas regras, pois aquele que não as interiorizar corre o risco de ver-se a si mesmo como incompetente, anormal, a-social, como detrito e lixo. (CHAUÍ, [1978] 2011, p. 24-25)

Nesta linha de entendimento, a competência, portanto, enquanto discurso do saber (científico) tal qual esboçamos acima, torna-se peça-chave no projeto de dominação e de intimidação social e política.

Para Lefort, é impossível apreciar o alcance do discurso da organização inerente à ideologia totalitária na nova ideologia sem levar em conta o trabalho efetuado pelas ciências humanas. A Sociologia e a Psicologia são responsáveis pela criação de um modelo geral de organização, de funcionamento da personalidade, além da elaboração de conceitos de integração social, comunicação, tensão e regulação. É notória a relação que a Psicologia mantém com o sistema de ensino, contribuindo para impor a imagem do indivíduo avaliado, obliterando a presença do mestre e contribuindo para imprimir o discurso do poder no invisível. De acordo com Lefort, "o psicólogo substitui o mestre para deslocar a relação com a lei, para afastar o golpe visível da 
autoridade e referir a sanção ao decreto de uma potência neutra e anônima." (FH, [1974] 1979b, p. 343)

Para Lefort, portanto, a nova ideologia se estabelece na esteira do trabalho exercido pela linguagem da ciência e da filosofia, em particular, pelas novas ciências sociais, algo que está relacionado ao ideal de cientificidade, de neutralidade, de racionalidade. Torna-se discurso anônimo, sem autor, nem produtor que passa através dos sujeitos, é falado por eles e tende a aparecer como algo que se cria e se recria pelo fato de conter uma racionalidade inerente à ordem das coisas.

Assim, a ideologia invisível faz com que as marcas do poder se façam invisíveis, algo que mantém uma relação direta com as teorias sobre o poder elaboradas no âmbito da sociologia funcionalista norte-americana ${ }^{100}$.

Em compensação, a concepção de um poder multiforme e ilocável me parece se inscrever na nova ideologia das sociedades ocidentais. O discurso de uma fração da intelligentsia faz eco com um discurso social que não tem mais nada a ver com aquele da ideologia burguesa; um discurso precisamente aplicado a tornar o poder invisível, a apagar os traços das divisões de classe, a atenuar a figura do mestre, os sinais da autoridade, da regra, a acreditar, em todo lugar, no fantasma de uma organização que determinaria, a partir dela mesma, a distribuição dos papéis sociais, de um universo relacional no qual a polarização do alto e do baixo seria puramente contingente. E o que confirma minha suspeita é a observação de que esta nova teoria do poder, apesar de ela mesma aparecer sob cores subversivas, advém, há um bom momento já, da sociologia funcionalista americana. É bom remontar às origens... (LT, [1978e] 2007, p. 365-366, grifo nosso)

Lefort critica a teoria racional do poder, a qual, na sua visão, afasta a noção de que o Ser do social é que está em questão na sociedade política. Tal teoria, de acordo com ele, vê os indivíduos como meros cruzamentos de diversas relações; cada um se encontra num determinado nível que o converte em controlador ou controlado. (cf. LT, [1976a] 2007, p. 285). Assim, compreendemos que Lefort não apenas faz uma crítica à ciência e à sociologia políticas, mas as compreende como peças importantes na constituição e manutenção do discurso da ideologia invisível, em virtude do discurso sobre o poder que veiculam através de algumas de suas teorias ${ }^{101}$.

\footnotetext{
${ }^{100}$ Consideramos que Lefort está se referindo aos trabalhos produzidos entre os anos 1960 e 1970, sob a influência de Talcot Parsons, entre os quais encontramos a análise sistêmica de David Easton, o pluralismo elitista de Robert Dahl e Seymour Martin Lipset.

${ }^{101}$ No quinto capítulo discutiremos a importância desta crítica no entendimento de Lefort sobre o pensamento do político, pois ele não apenas concebe uma diferenciação de ordem epistemológica com
} 
Lefort considera que tal ideologia tem sido veiculada pelo poder, assim como pelas contestações do poder, ocorridas em 1968. Trata-se de uma ideologia da boa comunicação, é uma ideologia da denegação da contradição, da denegação da divisão (cf. LT, [1979e] 2007, p. 397). Pois, enquanto na ideologia burguesa todas as divisões são nomeadas, reguladas, pelo fato de ser um discurso de caráter legislador, ético e pedagógico, na ideologia invisível, elas deixam de ser plenamente afirmadas. Lefort se refere à divisão do normal e do patológico, à diferença do adulto e da criança, à diferença dos sexos, à diferença do civilizado e do não civilizado (cf. ibid., p. 397). Há, portanto, um tipo de des-diferenciação em que os lugares e os papéis mostram-se confusos, como no exemplo que ele dá entre o pai-adulto e o filho-criança, pois considera que esta ideologia impede a plena identificação do lugar de cada um naquela relação.

Nessa perspectiva, a ideologia invisível tem o efeito de "denegar a autoridade" (ibid., p. 397). Podemos identificá-la no domínio da pedagogia, a qual pretende apagar a diferença entre o mestre e o aluno, o estatuto da regra. Com isto, toda uma geração se faz com referência a uma falta pela crise da autoridade moral explicitada pela ideologia burguesa. Lefort refere-se a uma cumplicidade que une os dirigentes - das empresas e do Estado - e os contestadores: a imagem de uma falsa modernidade, tornando o fenômeno da autoridade ininteligível ${ }^{102}$ (cf. LT, [1979e] 2007, p. 401).

Nas democracias, portanto, a ideologia invisível propaga-se de um meio particular para outro, de um núcleo cada vez mais aparentemente circunscrito a um núcleo aparentemente indeterminado e é pelo efeito de sua réplica indefinidamente multiplicada do polo privado da instituição ao polo público da informação que ganha a generalidade necessária à sua obra de homogeneização do campo social. Homogeneização, no entanto, que permanece no implícito. Dessa maneira, dizemos que não há totalização, mas há homogeneização. Impõe-se a imagem da reciprocidade como sendo a da própria relação social. "Essa imagem é duplamente eficaz, pois, simultaneamente, a comunicação é exaltada, independentemente de seus agentes e de

relação à ciência política, como também de ordem política, uma vez que, em nossa perspectiva, este pensamento se constitui como uma crítica à ideologia.

${ }^{102} \mathrm{O}$ grande problema que pode surgir de tais considerações é confundir esta leitura de Lefort como se o autor estivesse fazendo uma revalorização da autoridade para alimentar o conservantismo. Não se trata disso, mas apenas de considerar que as figuras do poder na sociedade tornam-se opacas, impedindo o trabalho da crítica. 
seu conteúdo, e a presença das pessoas encontra-se simulada (...)" (FH, [1974] 1979b, p. 336)

Nesse sentido, Lefort compreende que as diferenças entre os lugares e os papéis dos sujeitos sociais são apagados por esta nova ideologia. Enquanto na ideologia burguesa a figura da autoridade é plenamente desenhada e dá uma segurança ilusória sobre o lugar de cada um, há, na ideologia invisível, uma "dissimulação dos lugares que recobre a permanência da desigualdade, da hierarquia social” (LT, [1979e] 2007, p. 396). Lefort afirma que há um esfumaçamento (estompage) das divisões sociais que na democracia burguesa eram plenamente visíveis, afirmadas.

A partir do que discutimos, compreendemos agora o que levou Lefort a denominar esta ideologia como "invisível”. Ela decorre de sua relação com a ideologia presente no totalitarismo, visto que está ocupada em "esfumar", em "atenuar" suas oposições características, em reconduzir ao latente seu projeto de totalização. Lefort também afirma que, em sua articulação com o poder, este discurso está aplicado a tornálo invisível, porque imprime-o na Organização ou pulveriza-o em redes (cf. LT, [1976a] 2007, p. 293). Ao mesmo tempo, este discurso ideológico não aparece como tal, pois "tende a se dissimular enquanto discurso" (cf. LT, [1982e] 2007, p. 498), tendo se tornado invisível, incrustado na fala comum como fala técnica, racional, oriunda de todos os setores da sociedade - econômico, político, jurídico, estético, pedagógico, etc. - e mantendo invisível o lugar de onde ele é emitido, pois ele se dissolveu na fala dos sujeitos sociais que o enunciam, o veiculam.

Portanto, a ciência e a técnica são mobilizadas pelo novo discurso ideológico para imprimir, nas relações entre os sujeitos sociais e na sua relação com o poder, a lei e o saber, uma fundamentação objetiva, neutra e anônima. A ideologia não aparece como tal, torna-se invisível, "enterrada no processo de socialização" (FH, [1974] 1979b, p. 339), o que a aproxima da ideologia totalitária, pois tende a se dissimular enquanto discurso ideológico, tornando invisível o(s) lugar(es) de onde é emitido. Assim, o discurso que é falado pelos agentes sociais reveste-se de qualificativos científicos, técnicos, de verdades postuladas, como se tudo pudesse ser absolutamente controlado e controlável, quantificado e quantificável, em virtude da crença na "auto-inteligibilidade do real e na auto-inteligibilidade do homem" (FH, [1974] 1979b, p. 341). A fala, então, não aparece como ideológica, mas sim como científica e o homem assume a identidade 
de "agente do conhecimento", "indivíduo avaliado", enquanto o social é visto como "coisa" sob controle, como racional e transparente, totalmente dominável ou, ainda, que há um "tudo visível”, “tudo manipulável”, tudo explorável” (ibid., p. 344-345). Todos os setores da vida social são esquadrinhados por esta verdade oriunda do conhecimento científico, obliterando a contradição entre dominantes e dominados, a fim de promover a unidade.

Ao pensar a ideologia invisível como uma das modalidades de ideologia presentes na democracia, consideramos que Lefort identifica a existência de certas latências totalitárias presentes neste discurso. Isso significa que o projeto totalitário torna-se invisível, sendo reconduzido ao latente, e a homogeneização permanece implícita, havendo a "economia de um enunciado sobre o homem total e a sociedade total” (LEFORT, 1974 , p. $345-\mathrm{FH})^{103}$. Isso significa pensar a ideologia invisível, pela ótica de Lefort, como uma espécie de discurso sui generis, produzido no seu aqui e agora, alimentando-se dos debates teóricos e querelas políticas em torno da relação entre democracia e totalitarismo. É como se este discurso falasse em nome de uma democracia que, no fundo, conserva-se muito próxima do totalitarismo.

Afirmar a invisibilidade do totalitarismo na democracia, por sua vez, pelo entendimento da reflexão entre as ideologias não equivale a dizer que ela é um "totalitarismo larval", mas sim que ela o conserva no seu horizonte, que certos referenciais totalitários foram remanejados pela nova ideologia.

\subsection{A contradição da ideologia invisível}

\footnotetext{
103 Na perspectiva de Thompson (1982), a ideologia invisível não pode ser entendida apenas como homogeneização e unificação, pois a fragmentação não foi apagada pela mídia e pelas organizações, podendo reforçar ao invés de erradicar as formas existentes de diferenciação. Ele considera que, ao enfatizar o fenômeno da homogeneização e da unificação, Lefort dá insuficiente atenção a estas considerações, pois não discute a importância da fragmentação na operação da ideologia, a qual pode manter um sistema de dominação apoiado no dissenso interno, a fím de manter certos grupos subordinados. Na mesma linha, Thompson também critica a perspectiva de Lefort, a qual negligencia a importância contínua das classes e conflitos de classe em sua leitura da ideologia. Comentando brevemente estas considerações, podemos dizer que Lefort pensa a ideologia como aquela que cria um imaginário da divisão social, impingindo uma visão distorcida dela, a qual pode também conter certa ideia de fragmentação, como vimos, em que as oposições são reconhecidas, o conflito é afirmado, mas não são fontes de indeterminação democrática, na medida em que são esfumados os sinais do poder. Nesse sentido, há sim, em sua perspectiva, a ideia de que a ideologia pode conter uma linguagem da fragmentação e, dessa maneira, criar a imagem de uma "democracia consumada", apoiada na ideia de um dissenso construído, quando, na verdade, ele não é fonte de possíveis, de novos direitos, pois está sob controle. A questão de classe, por sua vez, não é retomada no sentido de Marx, mas sim de Maquiavel, como a divisão dominantes-dominados, justamente para não pensar a ideologia como lógica das ideias dominantes, sob o ponto de vista da atuação da classe burguesa.
} 
Pela exposição das duas ideologias anteriores, verificamos que há uma transformação do discurso ideológico que segue a transformação histórica. Nesse sentido, a ideologia invisível também está sujeita a este movimento, pois a sociedade histórica mina toda representação de sua instituição, abrindo, então, a possibilidade da contradição. Como afirma Lefort, a busca da coincidência entre o discurso ideológico e o real engendra as condições para uma contestação:

Quanto mais o discurso sobre o social [ideologia] procura coincidir com o discurso social, quanto mais se dedica a dominar o movimento indominável da instituição, a apossar-se dos signos do instituinte, tanto mais corre o perigo de perder a função assumida pela ideologia até agora: a legitimação da ordem estabelecida, não somente a de um regime de propriedade, mas a do real como tal; a busca da coincidência engendra as condições de uma contestação que (no Leste e no Oeste) visa, para além das expressões do poder e da exploração, às marcas da socialização no mundo moderno e recoloca a questão do Outro, a questão do Ser. (FH, [1974] 1979b, p. 345)

Não é por acaso que Lefort utiliza a palavra contestação para se referir ao movimento de transformação da ideologia, pois ela é responsável por colocar a ideologia em questão e dar passagem ao encadeamento de críticas. Mas, devemos, então perguntar, se a ideologia não está fadada a acabar, como garantir as virtudes da democracia sob a égide da ideologia invisível? Ou melhor, seguindo a compreensão que Lefort tem da democracia como invenção, de que modo ela pode manter este princípio sob a ideologia invisível?

Com relação à ideologia, propriamente, nos centrando nesta ideia de que ela nunca acaba, mas sempre se transforma, perguntamos qual é a relevância da crítica neste processo, ou seja, qual eficácia pode assumir a crítica e qual significação ela tem para Lefort, bem como qual impacto pode exercer nos sujeitos sociais e nas formas de sociedade Democrática e Totalitária?

Após toda esta reflexão, constatamos que as elaborações de Lefort sobre a ideologia nos remetem ao sentido de "obra", ou seja, a ideologia, na sociedade histórica, nunca acaba e para a decifrarmos, devemos nos descobrir implicados no discurso ideológico, agindo como seus leitores e como intérpretes ${ }^{104}$. Devemos, então, falar em contato com este discurso que afirma certezas sobre o social. Somos leitores modernos,

${ }^{104}$ No fundo, conforme argumentaremos, parece que Lefort tem um projeto de educação política neste trabalho de leitura e de interpretação da ideologia que se dá sob a forma de um pensamento do político para o homem democrático - a ser discutida no quarto capítulo. Há uma "Paideia" neste projeto e não apenas uma leitura crítica do mundo, porque implica ação. 
mas devemos ter em mente a interconexão estabelecida pela ideologia com outros tempos, outros discursos, assim como ocorre com a obra de pensamento.

O próximo capítulo apresenta uma discussão sobre a relação entre a democracia e a ideologia, considerando as reflexões de Lefort sobre este regime. No quinto capítulo, discutimos de que modo ele concebe a crítica à ideologia, as condições de sua emergência, o seu significado e principais consequências, além de discutirmos mais amplamente esta noção de deciframento da ideologia a partir da compreensão que detém Lefort sobre a obra de pensamento. 


\section{CAPÍTULO 4 - A “obra" da ideologia na "invenção democrática"}

\section{Introdução}

No capítulo anterior, discutimos os traços de um tipo de ideologia presente nas sociedades democráticas contemporâneas: a ideologia invisível. Quando pensada sob a perspectiva dessa ideologia, todos os traços que fazem a vida política desta forma de sociedade tornam-se opacos, transmutados em representações que têm o efeito de denegar todas as suas referências simbólicas. Falamos, então, de uma democracia fantasmática, compreendida pela égide da reciprocidade e não do conflito, sob o imperativo de um discurso que se faz passar por discurso democrático, tirando benefício dos recursos da ciência e da técnica para esquadrinhar todos os setores da vida social, dando-lhes uma fundamentação técnica, objetiva, neutra e anônima.

Ao localizarmos essa discussão no plano da obra de Lefort, esta reflexão realça os contornos de uma democracia que está distante daquela que o autor nos dá a conhecer pelo nome de "invenção democrática", ${ }^{105}$ nos escritos em que procura ressaltar o sentido do antagonismo e da oposição entre democracia e totalitarismo. Nestes estudos, Lefort reflete principalmente sobre os contrapontos entre estas formas de sociedade para revelar a diferença de essência entre elas, a primeira entendida como “invenção permanente" e a segunda como "revolução anti-democrática" (LT, [1988] 2007, p. 604) nascida no bojo dos paradoxos e ambiguidades inerentes à democracia ${ }^{106}$.

A discussão que pretendemos fazer mantém no horizonte esta imbricação entre democracia e totalitarismo, mas tem como principal objetivo remeter a discussão para o significado da "dobra" democrática, ou seja, para o entendimento de que ela não se dissocia da ideologia, a fim de compreender que ela se revela também pela denegação e pela constituição de determinações e certezas sobre si mesma. Procuramos também

\footnotetext{
105 Esta expressão foi utilizada como título de um dos livros de Lefort: A invenção democrática: os limites da dominação totalitária (1983a) e sintetiza a ideia de que a democracia é invenção permanente, pois não possui um fundamento determinado sobre si mesma.

${ }^{106}$ Esta relação é central na obra de Lefort, sendo explicitada em praticamente todos os seus artigos, em entrevistas e nos seus prefácios.
} 
deslocar o eixo da reflexão comumente estabelecida sobre a obra de Lefort, a qual procura ressaltar os traços de uma indeterminação democrática pura, quando, a nosso ver e, de acordo com Lefort, ela se constitui como um jogo entre certeza e incerteza, entre determinação e indeterminação por meio do trabalho da ideologia.

Nesse sentido, este capítulo articula o problema da petrificação democrática com a denominada "invenção democrática". A discussão que, aparentemente, levaria a duas ideias opostas de democracia - uma delas marcada pela cristalização ideológica e a outra pela criação histórica-, na verdade, remete-nos ao entendimento de que se trata de uma mesma forma de sociedade em que certeza e incerteza, determinação e indeterminação não se desvinculam. Ao refletir sobre a ideologia, a partir de Lefort, somos levados ao entendimento das contradições da forma democrática de sociedade, cujo ponto de partida vem a ser o afastamento da noção de boa sociedade. Nesse sentido, importa considerar as ambiguidades e contradições inerentes a ela, particularmente "onde ela se presta à formação de ideologias e de movimentos totalitários" (LT, [1982b] 2007, p. 476), ou seja, dizer que a democracia não constitui uma forma perfeita de sociedade, ela é perpassada por um debate e uma apreensão ideológica de si mesma, além de propiciar a passagem para o totalitarismo.

Lefort mantém-se atento às virtudes e aos problemas presentes na democracia, considera-a como revolução indefinida, devendo sempre ser reinventada para que se afaste o perigo do totalitarismo, visto que ela mantém uma atração pelo UM, pela homogeneização, pelo projeto totalizante, mantido em sua latência e constituindo nosso modo de existência política. Consideramos, neste momento da tese, não apenas os sinais de invenção da democracia, mas também os que apontam para a sua perversão, salientando o que pode fazê-la passar para a forma totalitária, destacando sobretudo qual é a obra da ideologia na democracia.

Para tanto, na primeira parte apresentamos o movimento de pensamento de Lefort sobre a democracia, após sua saída do grupo Socialismo ou Barbárie (1958), uma vez que dá passagem a uma nova tarefa intelectual, com vistas a compreendê-la sob uma perspectiva crítica relativa aos pontos de vista marxista, da ciência e sociologia políticas. Em seguida, discutimos as reflexões desenvolvidas, no bojo desta nova tarefa, a qual procura compreender a democracia em sua dimensão simbólica, como forma de sociedade, mantendo uma relação com duas outras formas - a monárquica e a 
totalitária. Atrelados a este entendimento centramo-nos no problema da invenção e das ambiguidades que podem fazer a democracia passar para o totalitarismo, e que lançam luz sobre o papel da ideologia, no sentido de constituir-se como um impeditivo do trabalho de invenção democrática. Por sua vez, isso provoca uma discussão sobre o problema de sua desvitalização.

Questionamos o problema do estabelecimento deste discurso sobre a democracia como discurso democrático que produz certezas e impede a interrogação, a "ética da dúvida" (cf. LT, [1993] 2007, p. 743) como uma incerteza fecunda no âmbito da sociedade democrática, o apagamento das marcas do poder em todos os domínios do social, cujo principal efeito é a visão de uma sociedade homogênea, sem conflitos, sem divisões, de uma democracia consumada pela imagem da reciprocidade. Neste cenário, os homens, sujeitos da palavra, não mais falam: é o discurso da ideologia que fala através deles (cf. LT, [1982e] 2007, p. 498), configurando a denegação da divisão. A democracia passa a ser compreendida como sendo habitada por ilusões sobre a natureza da igualdade - fundamentada na busca pela uniformização, pela homogeneização - e sobre a natureza da liberdade - a busca pela superação do conflito.

O capítulo se fecha com uma reflexão sobre as respostas dadas por Lefort a estas questões, argumentando-se sobre a relevância de um trabalho de questionamento permanente na democracia, fundado na contestação, na busca pelo estabelecimento de novos direitos para manter afastado o totalitarismo, assim como a imagem fantasmática da democracia. Revelar-se-á importante uma ética da dúvida, capaz de garantir a elaboração de novos discursos contraideológicos, uma reflexão que nos levará ao quarto capítulo em que nos debruçamos sobre a natureza deste discurso e as condições de sua possibilidade.

\section{A teoria da democracia de Claude Lefort}

\subsection{Aportes críticos para a nova tarefa intelectual: (re)pensar a democracia}

Após sua saída do grupo Socialismo ou Barbárie em 1958, Lefort abre uma nova via em seu pensamento, atrelada à nova tarefa de interrogar a democracia. Em um artigo publicado em 1966, intitulado "Pour une sociologie de la démocratie" (EL, [1966a] 1979c,), ele já anuncia que quer introduzir um debate sobre a democracia e 
lançar questionamentos que o preparavam para um trabalho futuro, o qual como se sabe, desembocou em suas reflexões sobre o caráter indeterminado da democracia.

A essa época, aponta que a democracia não se resume a um conjunto de instituições, e tece considerações críticas às concepções estabelecidas sobre sua significação, provenientes do esquema liberal e do esquema marxista, os quais, na sua ótica, estavam fundados em uma perspectiva objetivista que, em nome de um conhecimento exato, excluíam do real a representação, os quais, na sua perspectiva, eram inseparáveis. Dessa maneira, o que ele percebe nestes estudos é uma compreensão sobre a democracia que a vê somente como um sistema de instituições políticas ou econômicas feito para funcionar e que tem o poder de determinar todos os traços da realidade social, o que, na sua ótica, tinha o efeito de opacificá-la, de torná-la um fetiche e criar uma imagem confusa do termo democracia.

A alternativa liberal-marxista, no seu entendimento, permanece em um formalismo, vendo a democracia como lógica institucional, na qual a explicação permanecia reduzida a uma lógica econômica. Dessa maneira, não se aprecia o alcance dos significantes em função dos quais ela se ordena, como indica Lefort, em relação à

Diversidade de grupos e de suas reivindicações, competição de seus representantes em vista de uma seleção de dirigentes, livre circulação de ideias e de informações, livre associação, contestação legítima do poder estabelecido, mobilidade do poder e, mais geralmente, da representação política, este conjunto de significantes não é determinado por um estado de relações de propriedade, ou de relações de produção, mesmo que venha se impor historicamente no quadro do capitalismo moderno. É necessário reconhecer que ela pode se manter sob condições adversas, sejam quais forem os quadros nos quais se manifesta o sufrágio popular, quais sejam sua forma e sua periodicidade, qual seja o procedimento de escolha dos governantes, e qual seja enfim o grau de desigualdade dos sujeitos políticos. (LT, [1966a] 1979c, p. 329)

Dessa maneira, ainda nos anos 1960, Lefort procura lançar um olhar para uma ordem de fenômenos que permanecem na constituição da democracia, a despeito daquilo que se manifesta na esfera econômica, ou melhor, na infraestrutura. Para criticar este formalismo, ele anuncia a "eficácia simbólica" como aquela perspectiva que estava em falta nos estudos marxistas e liberais sobre a democracia: "Julgar que as instituições e as regras da democracia burguesa não constituem senão um aspecto do modelo político democrático é, então, reconhecer que esta possui uma eficácia simbólica que é de outra ordem que a eficácia restrita de um regime de fato." (EL, [1966a] 1979c, p. 330) 
Na sua perspectiva, era necessário compreender aqueles significantes e deixar de projetar no campo objetivo, oferecido à descrição científica, oposições que são da ordem do simbólico. Com relação ao poder, Lefort considerou que ele não pode ser reduzido à relação que os dominados têm com um órgão que materializa a potência de dominação de Estado, como se ele se definisse apenas por suas funções - a coerção -, pois ele cria a unificação imaginária de uma sociedade dividida de fato. $\mathrm{O}$ mesmo ocorreria com a Lei, vista como sistema de obrigações que resultam das necessidades empíricas da divisão de classe, fixando os estatutos e os papéis num quadro marcado por relações de força. Da mesma forma, os discursos sociais, religiosos, míticos e ideológicos são reduzidos ao plano de uma interpretação geral das relações do homem com a natureza, ou das relações do homem com o homem, comandada pela idealização de condições sociais particulares.

A nova tarefa intelectual de Lefort consistiu em criticar a projeção realista da democracia, vista como um regime político, como conjunto de instituições destinadas a funções especiais, ligadas à classe burguesa, no sentido de instalar pacificamente o reino da burguesia, isto é, de obter ao menor custo a obediência dos dominados persuadindose de que eles dispõem de uma parcela de poder equivalente àquela dos dominantes, que eles se beneficiam dos mesmos direitos e da mesma liberdade. Para Lefort esta análise tem o efeito de mascarar o acontecimento da democracia, na Europa moderna, e que não se deixam medir somente pelos efeitos que são reparáveis no quadro institucional e que favorecem uma classe. Tal ruptura deve ser compreendida em termos políticos, isto é, reconhecendo-se sua dimensão simbólica.

A postura de Lefort está, então, relacionada à compreensão de que havia um desconhecimento sobre o sentido da democracia política (cf. EL, [1966a] 1979c, p. 329), pois o termo havia se tornado uma garantia, uma forma de tranquilizar aqueles que se achavam em um mundo polarizado pelo fato comunista. As análises nada mais faziam a não ser postular a boa imagem da democracia, no sentido de se buscar a verdadeira democracia, em oposição à burguesa, sem que se percebesse que a democracia integral é um ideal. A palavra, então, acabava por "mascarar as lacunas do saber e manter a seu custo a boa imagem da sociedade" (ibid., p. 324-325), isto é, buscava afirmar uma boa ideia de democracia para barrar o acesso ao entendimento de que ela é feita de uma indeterminação. O que significa, então, que o próprio termo democracia acabou fazendo parte da ideologia, havia se tornado opaco e um fetiche, 
impedindo o trabalho da interrogação. É por isso que a nova tarefa intelectual de Lefort consistiu em questionar o seu significado.

O conceito de democracia está ligado a uma indeterminação manifesta: ele é vago e nos escapa. A verdade desta indeterminação é desconhecida. Sob o pretexto de tê-la positivamente, nós pretendemos reduzir a realidade social a um sistema, ou um sistema de sistemas feito para funcionar. Consideremos, por sua vez, os estudos objetivos que visam substituir o arbitrário da ideologia à seriedade da interpretação dos fatos: vemos a democracia no Estado, a democracia no Plano, a democracia na Empresa, no Sindicato, na Universidade: quadros bem delimitados que permitem especificar os traços de seu funcionamento. Mas, seja qual for o interesse de tal ou tal análise, o termo torna-se fetiche, se opacifica e não oferece mais ao pensamento que o artifício do qual ele necessita para colocar um limite a suas questões. Falamos de democracia, mas importa se interrogar, não dizemos sobre as dificuldades da coisa amamos repetir que elas não serão jamais eliminadas, que a democracia integral é um ideal, que conta somente o movimento que a inspira - mas sobre a verdade disto que ela postula. A palavra lá está para tranquilizar, para mascarar as lacunas do saber e manter a seu custo a boa imagem da sociedade. (EL, [1966a] 1979c, p. 324-325)

É importante salientar que, neste projeto, de Lefort está pressuposta a compreensão de que a democracia não pode ser fechada em uma significação, tal como a noção de democracia burguesa ${ }^{107}$, justamente porque ela é feita, conforme veremos à frente, de um trabalho incessante de reelaboração de sua identidade. A postura de Lefort está muito mais para a condição de questioná-la, do que de estabelecer respostas, fazendo seu pensamento da democracia ser trabalhado pela própria indeterminação democrática $^{108}$. Ele afirma que

Nossa interrogação apela, então, para uma resposta que não é indiferente à sua natureza, seria uma resposta que não terminaria, mas que a especificaria de tal maneira que ela torna manifesta, legítima e necessária o referente democrático - porque instituições, condutas, valores, em todo o espaço social, se reportam uns aos outros, se expõem, se elevam à mesma impossibilidade de escapar à medida do outro. (EL, [1966a] 1979c, p. 326)

\footnotetext{
${ }^{107}$ Na ótica de uma reflexão da Democracia a partir da ideologia, a Democracia burguesa seria regida por um tipo de discurso ideológico, calcado nas representações de uma classe - a Burguesia. O que quer dizer que a Democracia não se reduz a este discurso, mas encontra-se sempre sujeita a ser apreendida por novas e velhas representações ideológicas, como é o caso da ideologia invisível, o discurso mais recente elaborado no século XX.

${ }^{108}$ Aqui está também a singularidade do pensamento de Lefort, um pensamento democrático, pois ele não procura fechar o entendimento que tem sobre a Democracia, no sentido de determiná-la como lógica institucional, por exemplo, e, em seguida, permanecer refletindo sobre tal lógica - o quanto favorece ou desfavorece a prática democrática. Ele procura seguir outro caminho, com vistas a abri-la como questão, atentando-se para o problema de suas ambiguidades como algo que dá a pensar o significado da experiência democrática. $\mathrm{O}$ trabalho de França também explicita alguns aspectos do pensamento democrático - indeterminado - de Lefort, pois considera que o trabalho de interpretação que está presente em sua obra mantém uma profunda e estreita ligação com a ética democrática (FRANÇA, 1998, p. 2)
} 
Comete-se um erro quando se confunde a democracia com um regime, um conjunto de instituições historicamente determinadas ou, ainda, como produto da classe burguesa. Lefort está convencido de que existe uma lógica inerente à democracia, a qual fornece a condição de possibilidade dos conflitos políticos ${ }^{109}$. A lógica da qual falamos somente se torna compreensível quando a comparamos a outras formas de sociedade: à monárquica e à totalitária.

\subsection{A democracia}

Para que possamos compreender o significado da democracia em Lefort, devemos considerar que ele a articula a duas outras formas: o Antigo Regime e o totalitarismo. Lefort os concebe como formas de sociedade, pois elas carregam em si um princípio de internalização que pode dar conta de um modo específico de diferenciação e articulação entre classes, grupos e categorias sociais. A forma (mise en forme) pela qual uma sociedade institui a si mesma envolve o engendramento de um sentido (mise en sens), pois, embora a sociedade não seja transparente a si mesma, ela é, todavia, perpassada por significações, em que as práticas sociais são reconhecíveis e significam algo. Além disso, há um jogo de cena (mise en scène) das relações sociais, através da qual a sociedade dá a si uma "quase-representação" de si mesma, que pode se constituir como aristocrática, monárquica ou despótica, democrática ou totalitária.

O Antigo Regime e a democracia, assim como o totalitarismo, são concebidos como formas de sociedade, as quais se tornam compreensíveis não apenas por seus caracteres empíricos que informam como se dão as relações sociais, como se caracterizam as instituições políticas, mas também pelas representações. O que torna estas reflexões de Claude Lefort relevantes é justamente a sua perspectiva do simbólico acerca dos fenômenos políticos. O autor está o tempo todo buscando o seu significado para além de uma perspectiva pautada sobre as instituições, de modo que, na reflexão

\footnotetext{
${ }^{109}$ Nessa linha de reflexão, Lefort desferiu uma crítica a Marx, que relacionou a democracia à dominação de classe burguesa. A principal crítica dirigida a este pensador nasce de sua leitura de Maquiavel e relaciona-se à ideia de que as relações de dominação entre as classes não podem ser exclusivamente deduzidas das relações de exploração. As relações políticas que se estabelecem entre as classes no seio de uma sociedade se esclarecem a partir da relação que a sociedade, no seu conjunto, estabelece com sua própria divisão. Há, portanto, uma lógica intrínseca às relações políticas que não podem ser atribuídas exclusivamente à lógica econômica. Assim, a questão da relação que a sociedade estabelece com sua divisão interna encontra-se no centro das análises de Lefort.
} 
sobre a passagem da sociedade democrática para a totalitária, por exemplo, não se trata de considerar as transformações no modo de produção, mas de compreender como o poder se reveste de uma nova significação simbólica, capaz de reunir a sociedade num todo orgânico e homogêneo ${ }^{110}$.

Iniciemos, então, pelo entendimento da sociedade monárquica, pois como ele afirma, "a singularidade da democracia só se torna plenamente sensível quando se traz à memória o significado do sistema monárquico sob o Antigo Regime” (PP, [1983b] 1991, p. 31-32). Nesta sociedade, a atenção de Lefort está voltada para a problemática do corpo do príncipe e o seu significado em uma ordem teológica, justamente para pensar de que modo a unidade social pode ser mantida e representada ${ }^{111}$.

De acordo com Lefort, no Antigo Regime, caracterizado por reinos territoriais - "um número infinito de pequenos corpos que dão aos indivíduos suas referências identificadoras" (ID, [1979a] 1983a, p. 117) -, o $\operatorname{poder}^{112}$ e a comunidade estão incorporados na pessoa do príncipe. O rei é compreendido por Lefort como aquele que dava $\operatorname{corpo}^{113}$ à sociedade, pela representação de um "corpo imaginário". Em tal regime,

\footnotetext{
${ }^{110}$ Poltier ressalta esta ideia ao afirmar que a compreensão de cada sociedade em Lefort é indissociável de um entendimento dos princípios geradores de sua instituição, de seu modo de engendramento, o que requer a comparação entre seus dispositivos simbólicos (POLTIER, 1998, p. 194).

${ }^{111}$ Para construir esta reflexão, Lefort concentra-se nos estudos que buscaram pensar o significado da Revolução Francesa na quebra com a antiga ordem e o surgimento da Democracia, presentes nos estudos de Michelet, Quinet, Tocqueville, além de outras reflexões que buscaram pensar o significado da Monarquia, como em Dante e também estudos mais contemporâneos como o de Kantorowicz.

${ }^{112}$ Para Lefort, o poder possui um estatuto simbólico. Nas palavras de Poltier, o poder é o lugar simbólico a partir do qual os princípios geradores de uma sociedade são suscetíveis de serem descobertos e decifrados. (cf. POLTIER, 1998, p. 212). A grande discussão de Lefort passa a ser, então, com a teoria racional do poder, por um lado, e com a teoria de Marx, por outro. O que significa que, na sua perspectiva, Marx se inclina a projetar no campo objetivo, oferecido à descrição científica, oposições que são da ordem do simbólico, a reduzi-las a conflitos empíricos aos quais se poderia apontar uma origem, um desenvolvimento e um fim. Neste caso, o Poder é reduzido à relação que os dominados estabelecem com um órgão que materializa a potência de dominação do Estado, como se o Poder se definisse por suas funções - aquela da coerção e aquela da unificação imaginária de uma sociedade dividida de fato. A relação à Lei se reduz ao sistema de obrigações que é o resultado das necessidades empíricas da divisão do trabalho e da divisão de classe, e fixa os estatutos e os papéis num quadro subtraído às flutuações de forças. Da mesma forma, tende ainda a tornar os discursos sociais, religiosos, míticos, ideológicos ao plano de uma interpretação geral das relações do homem com a natureza, ou das relações do homem com o homem, comandada pela idealização de condições sociais particulares (ver também HT, [1976c] 1976b, p. 193). Ele afirma também que "nada coloca em maior evidência as consequências da projeção realista que a representação da democracia como regime político, como conjunto de instituições destinadas a funções especiais: aquelas de instalar pacificamente o reino da burguesia, isto é, de obter ao menor custo a obediência dos dominados, persuadindo-os de que eles dispõem de uma parcela de poder equivalente àquela dos dominantes, que eles se beneficiam dos mesmos direitos e da mesma liberdade". (cf. HT, (1976c] 1976b, p. 193-194)

${ }^{113}$ Lefort parte de Ernst Kantorowicz (2007) para elaborar a sua ideia sobre o corpo político, visto que este último faz uma referência ao corpo de Cristo, duplo enquanto corpo místico e corpo humano na obra The king's two bodies: a study in mediaeval political theology.
} 
o príncipe age como mediador entre os homens e Deus ou, quando se dá o processo de secularização e do laicismo da atividade política, torna-se um mediador entre os homens e as instâncias transcendentes figuradas pela Justiça soberana e pela Razão soberana (cf. PP, [1983b] 1991, p. 32). Assim, ao mesmo tempo em que está submetido à lei, o príncipe também está acima das leis, condensando em seu corpo, mortal e imortal ao mesmo tempo, os princípios responsáveis pela geração e pela ordem do reino. Segundo Lefort, o príncipe "via a si mesmo afigurar-se como um corpo, como uma unidade substancial (...). Incorporado no príncipe, o poder dava corpo à sociedade. E assim, havia um saber latente, mas eficaz, do que um significava para o outro, em toda a extensão do social." (ibid., p. 32). Dessa maneira, havia um sentido de unidade política que não se dissociava da ordem teológica, na qual se condensava o poder, a lei e o saber.

Muitas vezes tive a ocasião de insistir sobre este fenômeno: durante séculos, nos grandes Estados da Europa, o poder estava incorporado na pessoa do príncipe ou na instituição em que ele era a cabeça. É verdade que ele não detinha um poder sem limite; ele devia respeitar o costume do reino, mas ele aparecia como um representante de Deus sobre a terra, ou melhor - quando se acentua a transferência dos símbolos religiosos no campo político - como um representante da soberana Razão e da Soberana Justiça (tudo em benefício de uma eleição divina). Com o corpo do monarca, corpo imortal conjugado com seu corpo mortal, se dava a imagem da geração e da ordem do reino. Assim, o poder político apontava para um polo incondicionado, a hierarquia, a distinção das ordens e das posições, pareciam repousar sobre um fundamento inabalável. O que significa que o poder, a lei, o saber (o conhecimento último dos fins da vida social, das normas que regem as relações dos homens entre si e suas atividades) se vêem como procedentes de uma mesma origem e condensadas numa mesma instituição. Dessa forma, isso significa que eles conferiam à sociedade uma unidade substancial, a consistência e os contornos de um corpo. (LT, [1993] 2007, p. 740)

A revolução democrática deságua, no momento em que "o corpo do rei é destruído, quando cai a cabeça do corpo político, quando, simultaneamente, a corporeidade do social se dissolve" (ID, [1979a] 1983a, p. 117). Com a democracia, opera-se uma mutação: não há mais poder ligado a um corpo. O poder aparece como um lugar vazio e "a sociedade não é mais representável como um corpo e não se afigura no corpo do príncipe" (PP, [1981b] 1991, p. 270). Estabelece-se uma nova determinaçãofiguração ${ }^{114}$ do poder que, desincorporado, torna-se um lugar vazio, ocorrendo também

\footnotetext{
114 Lefort usa o termo "figura" "para dar a entender que é da essência do poder fazer-se ver e tornar visível um modelo de organização social.” (ID, [1980a] 1983a, p. 79)
} 
uma mudança nos princípios de legitimidade, no remanejamento de crenças e no modo de apreensão da realidade.

A democracia moderna me parece ser o produto de uma inversão, aquele do sistema monárquico, teológico-político. Neste sistema, o princípio mesmo do saber e da lei se encontra incorporado no poder que é, ele mesmo, incorporado na pessoa do príncipe. $\mathrm{Ou}$, o nascimento da democracia moderna se faz sob o signo da afirmação de um direito e de uma lei acima de um poder que não pode jamais deles se apropriar. O que me parece mais notável nesta inversão - na esteira disto que foi o sistema constitucional liberal -, é o fenômeno da desincorporação e da desintrincação do saber, da lei e do poder. A democracia implica a ideia de que o poder não pertence a ninguém. Com seu acontecimento, se opera uma mutação simbólica tal que o poder continua a aparecer acima da sociedade, mas, simultaneamente, engendrado por ela. Ainda que seja verdade que a democracia suscita o fantasma de uma sociedade sem poder, este não se abole nela. Ele continua assegurando as condições da coesão social. Entretanto, ainda que ele não coincida mais com a pessoa daquele ou daqueles que dele estão investidos, ele se revela inlocalizável, infigurável, indeterminado. (LT, [1986b] 2007, p. 560, grifos do autor )

No imaginário da sociedade moderna, o poder vem a ser aquele que engendra e é engendrado pela sociedade, de tal forma que ele ocupa uma posição externa e interna, ao mesmo tempo, ou seja, ele vem a ser um órgão distanciado, acima da sociedade, capaz de apreendê-la no seu conjunto, responsável por figurar a generalidade do social; e, de outro ponto de vista, ele aparece circunscrito na sociedade, associado ao exercício de uma atividade particular assumida pelos homens que, por princípio, se modificam. $\mathrm{O}$ que significa que a política vem a se constituir como um campo de ação e que o poder mantém um caráter transcendente, como lugar do alto, a apreender a sociedade como um todo ${ }^{115}$.

Lefort considera que o poder tem uma face visível, ou seja, que ele aparece por meio de um grupo no poder que o exerce. Ao mesmo tempo, há outra face do poder que permanece invisível na modernidade: “a sua função é instituinte” (LT, [1988] 2007, p. 601), isto é, não podemos pensar apenas as relações de força, mas também que o poder é instituído e é aquele que institui a sociedade, pois é sinal de uma não coincidência da sociedade com ela mesma, de uma transcendência que lhe torna sensível sua identidade - tem uma significação metapolítica. (ibid., p. 602).

\footnotetext{
115 Gostaríamos de esclarecer que, em Lefort, o poder conserva um caráter transcendente, justamente porque se torna imanente, ou seja, reportado a si mesmo e não mais ao fora e, portanto, permanece constantemente em busca de um fundamento para si, o qual é fornecido pela dinâmica estabelecida nos debates críticos e ideológicos. O grande perigo está na possibilidade de que o lugar vazio seja ocupado e um só discurso venha conferir o fundamento, ou melhor, uma identidade para o social.
} 
A desincorporação do poder ocorrida na democracia nos remete a um entendimento sobre o desintrincamento das esferas da lei, do saber e do poder, assim como a questão da representação política. Com relação ao desintrincamento, compreendemos que, para Lefort, a democracia constitui uma forma de sociedade onde não há mais um referencial capaz de incorporar aquelas três esferas como ocorria no Antigo Regime, através do corpo do Rei. Elas se estabelecem como domínios separados e articulados na forma de sociedade democrática.

Devemos compreender ainda que a desincorporação do poder vai necessariamente de par com um desintrincamento do poder, da lei e do saber. Quando o príncipe deixa de ser investido de uma autoridade incondicional, se apaga a ideia de que a lei escapa ao domínio dos homens, que ele está inscrito na ordem da natureza ou procede da vontade de Deus. (LT, [1993] 2007, p. 740-741)

Nesse sentido, a democracia contém um traço essencial: nela há um novo sentido de limite que rompe com a imagem do corpo. A atividade política choca-se com um limite, de modo que os detentores da autoridade não devem transgredi-lo. Eles devem respeitar a independência da justiça - da Lei (o que não significa que tal princípio não seja violado); eles não podem decidir sobre a organização da economia (o que não quer dizer que eles não devam limitar os efeitos de suas desordens ou, que os interesses privados dominantes não pesem sobre as decisões públicas) ${ }^{116}$; eles não podem ter em tutela os homens da ciência, os ensinamentos, os escritores ou os artistas, não podem submeter a informação a uma censura arbitrária - o Saber. Lefort se pergunta: o que é a desincorporação do poder? Como resposta diz:

A autoridade política deixa de exercer uma legitimidade absoluta. Aqueles que o exercem se vêem constantemente em busca de sua legitimação. O pluralismo de partidos não se reduz, como se afirma comumente, a um artifício ao serviço da seleção de dirigentes destinados a assumir a coesão do conjunto social e a gestão dos interesses comuns; a instauração do sistema representativo deriva da impossibilidade ou, melhor dizendo, da rejeição de um poder que tenha uma função de encarnação. Ou, observamos ainda, uma sociedade que não é mais suscetível de ser encarnada, não pode se dar a imagem de uma unidade orgânica, ela se reconhece como irredutivelmente plural. Tal foi, em efeito, o ensinamento que os Americanos tiraram, os primeiros, daquela revolução, em 1787, ao final dos debates e conflitos que se estenderam por uma dezena de anos, fazendo de todos os órgãos do poder, não somente da esfera do legislativo, mas também do executivo e do judiciário, órgãos representativos. (LT, [1993] 2007, p. 741)

\footnotetext{
${ }^{116}$ Em virtude do desintrincamento da lei, do poder e do saber, temos também a emergência de outras esferas - econômica, estética, etc. Para as reflexões que procuramos desenvolver, nos deteremos apenas nas três primeiras.
} 
Essa disjunção que se opera na democracia entre o Poder, a Lei e o Conhecimento não quer dizer que haja um tipo de isolamento que possa ser atribuído a estes domínios, mas sim a ideia de que se estabelece na forma de sociedade democrática uma lógica segundo a qual, tendo em vista o caráter inocupável do poder, a lei e o saber são concebidos numa indeterminação que os subtrai à ilusão que haveria em buscar um fundamento concebível da legitimidade e da verdade.

Novamente, para compreender esta ideia, devemos retomar a relação de imbricamento do sistema monárquico, no qual o príncipe é o único detentor e enunciador da lei, disposta como uma verdade. A disjunção a que estamos nos referindo não podia ser apreciada, pois a autoridade soberana procedia de um único lugar de potência, da ordem do mundo e de conhecimento, ou seja, condensando neste lugar o poder, a lei e o saber para garantir a integridade do corpo social.

Na democracia, a disjunção tem o efeito de permitir um debate, uma contestação fixada em ideias sobre o que é legítimo, ilegítimo, bom, mau, de tal forma que se abre uma via para que a lei se constitua pelo jogo do debate, da enunciação dos direitos e que o poder seja sempre reenviado a ele. Com a democracia, nasce, então, o "espaço público", a liberação da palavra onde há a abertura do campo do dizível e do pensável, o qual apenas pôde se constituir porque a sociedade democrática não detém um saber total sobre si mesma. Dessa maneira, para alcançar sua inteligibilidade, a sociedade democrática depende do trabalho de deciframento que se mantém preso à experiência.

$\mathrm{Na}$ democracia, a lei se estabelece numa sociedade em debate, de tal forma que a ninguém se atribui a condição de depositário da lei, pois se apaga a imagem do grande juiz e nasce uma nova relação: a do sujeito com a lei, pois no mesmo instante em que o indivíduo é chamado a obedecer ele também é capaz de julgar de seu próprio lugar. A lei requer o trabalho interminável de sua enunciação, ao mesmo tempo em que se estabelece, segundo Lefort, "uma ligação entre a opinião e a lei (a vontade da maioria que é sempre temporária) e entre o sujeito e a lei, a qual não cessa de se fazer”. (LT, [1993] 2007, p. 741-742) 
A democracia moderna afirma, então, a legitimidade do debate sobre a distinção do legítimo e do ilegítimo ${ }^{117}$. E é se interrogando sobre esta distinção que chegamos mais próximos dessa questão da lei que nos reenvia a uma compreensão sobre a democracia de direito como calcada na afirmação de uma fala - individual ou coletiva - que faz valer sua autoridade, pois

O que distingue a democracia é ter inaugurado uma história na qual foi abolido o lugar do referente de onde a lei ganhava sua transcendência, o que não torna, por isso, a lei imanente à ordem do mundo, e, ao mesmo tempo, não confunde seu reino com o do poder. Faz com que a lei, sempre irredutível ao artifício humano, só dote de sentido a ação dos homens com a condição de que eles assim o queiram, de que eles assim a apreendam, como razão de sua existência e condição de possibilidade para cada um de julgar e de ser julgado. A separação entre legítimo e ilegítimo não se materializa no espaço social, é apenas subtraída à certeza, porquanto ninguém poderia ocupar o lugar do grande juiz, porquanto esse vazio mantém a exigência de saber. Dito de outra maneira, a democracia convida-nos a substituir a noção de um regime regulado por leis, de um poder legítimo, pela noção de um regime fundado na legitimidade de um debate sobre o legítimo e o ilegítimo - debate necessariamente sem fiador e sem termo. Tanto a inspiração dos direitos do homem quanto a difusão dos direitos em nossa época atestam esse debate. (PP, [1984b] 1991, p. 57, grifos do autor)

No que diz respeito ao Saber, Lefort considera que, se ninguém encarna o poder, se ninguém é o grande juiz, ninguém está em condição de decidir as normas do conhecimento e de circunscrever seu campo. Nesse sentido, ele registra o significado da emancipação da ciência do quadro teológico como um fenômeno que marca o acontecimento da sociedade moderna. Em contraste com os regimes totalitários, a democracia permite o exercício do livre exercício dos modos de conhecimento e de expressão - filosofia, história, sociologia, psicologia, literatura - que têm uma incidência direta ou indireta sobre os costumes e sobre a política. Dessa maneira, há diversos discursos sociais, desenrolando-se em busca de seu próprio fundamento, uma vez que falta um saber geral sobre a ordem do mundo e a ordem social em conjunção com o poder do Estado. Estes discursos reenviam-se uns aos outros, mas, diferentemente do que ocorre no totalitarismo, não estão condensados em um único discurso. Assim, eles participam da instituição do social e a decifram, associando-se àquela desarticulação do poder e da lei que explicitamos há pouco, de modo, então, que eles participam da constituição de um saber relativo aos direitos, relativo ao poder,

\footnotetext{
${ }^{117}$ Rummers (2008) aproxima Habermas e Lefort, relacionando a sua teoria da democracia deliberativa à importância do reconhecimento do conflito como algo constitutivo. Nesse sentido, considera o significado de uma deliberação interrompida, ou seja, a ideia de que todas as decisões políticas são interpretações temporárias do bem do povo, de modo que não se deve buscar deliberações definitivas, pois estas podem ser sempre rediscutidas, debatidas novamente, compreendendo-se o cidadão como autor e sujeito político.
} 
conferindo ao social sua identidade. É por isso que, na disjunção entre o poder, a lei e o saber, o primeiro permanece sempre na dependência da lei e também indissociável da experiência que se tem dele, uma experiência que é da ordem do saber, da linguagem, da articulação do discurso.

Ao mesmo tempo, o poder é indissociável da representação, isto é, da ideologia, que, por sua vez, é da ordem do saber, sendo um discurso de conhecimento sobre o real, encontrando na ciência uma importante aliada no estabelecimento de sua natureza discursiva, ao mesmo tempo em que se estabelece no lugar da explicação teológica do mundo, mantendo com esta explicação uma relação de parentesco que já explicitamos no capítulo anterior. Assim, a ideologia nasce no bojo dos deslocamentos de discurso que ocorrem na sociedade histórica, em especial na sociedade democrática. Antes de considerarmos o seu papel na democracia, gostaríamos ainda de refletir sobre a representação política.

A democracia marca uma transformação importante, tanto no lugar do poder inocupável, a não ser temporariamente - como na configuração da sociedade, dissolvida, desincorporada $^{118}$. No que concerne ao primeiro, o lugar vazio indica que aqueles que o exercem não o detêm, ou melhor, não o encarnam ${ }^{119}$. Isso exige uma competição que se renove periodicamente, constituindo uma autoridade que se faz e se refaz em virtude da manifestação da vontade popular.

O lugar do poder torna-se um lugar vazio. Inútil insistir nos pormenores do dispositivo institucional. O essencial é que impede aos governantes de se apropriarem do poder, de se incorporarem no poder. Seu exercício depende do procedimento que permite um reajuste periódico. É forjado ao termo de uma competição regrada, cujas condições são preservadas de maneira permanente. Esse fenômeno implica a institucionalização do conflito. Vazio, inocupável - de tal maneira que nenhum indivíduo, nenhum grupo poderá lhe ser consubstancial -, o lugar do poder mostra-se infigurável. São visíveis unicamente os

\footnotetext{
118 A "desincorporação" dos indivíduos ocorre, segundo Lefort, quando o corpo do rei é destruído, "quando cai a cabeça do corpo político" e a "corporeidade social se dissolve". (ID, [1979a] 1983a, p. 117118). Lefort encontra em Jules Michelet, em sua obra Histoire de la Révolution Française (1952) a ideia segundo a qual no Antigo Regime, o mistério da encarnação monárquica descobre-se na representação inconsciente de uma sociedade que se encarna no rei, se ordenando não apenas através de suas instituições políticas, segundo um "princípio carnal”, mas também pelos seus membros que são captados pela imagem do corpo, projetando nele sua própria união, seus afetos, precipitando-se numa identificação amorosa com esse corpo (PP, [1981b] 1991, p. 281)

${ }^{119}$ Lefort ressalta que "não se deve confundir a idéia de que o poder não pertence a ninguém com a idéia de que ele designa um lugar vazio" (PP, [1981b] 1991, p. 263). No primeiro caso, os atores políticos podem ser os formuladores da ideia, o que deve denotar, portanto, que o poder não pertence a ninguém "d'entre nós", ou seja, preserva um vínculo com a presença de um grupo. Enquanto a indicação de um lugar vazio furta-se à fala e visa apontar para uma sociedade sem determinação positiva, irrepresentável na figura de uma comunidade.
} 
mecanismos de seu exercício, ou então os homens, simples mortais, que detêm a autoridade política. (PP, [1983b] 1991, p. 32, grifo do autor)

É neste sentido que Lefort concebe a questão da representação política sob a perspectiva do lugar vazio do poder, pois considera que a democracia constitui uma forma de sociedade na qual o poder não pode ser entendido como alternância, pura e simplesmente, ou seja, no sentido de que todos podem ocupar periodicamente o poder, mas sim pela ideia de que ninguém pode se identificar com o poder, como ocorria na forma de sociedade monárquica.

O poder adquire uma dinâmica diferente na democracia, a qual é derivada da impossibilidade de sua incorporação. Instaura-se um movimento contínuo de reajuste, ou d'une remise en jeu périodique, isto é, o exercício de recolocar periodicamente o jogo político (cf. LEFORT, 1986a). O poder como lugar vazio adquire um caráter inapropriável, dá-se a institucionalização do conflito e aqueles que ocupam o poder figuram como homens, simples mortais, dada a perda a um referencial externo, imputável aos deuses. O povo é dito soberano e sua vontade é responsável pelo ato de fazer e refazer a autoridade política ${ }^{120}$.

$\mathrm{Na}$ "encenação" ou, para usar o termo de Lefort, mise en scène, uma sociedade constitui sua própria identidade numa quase-representação de si mesma, pois ela é sempre provisória, refazendo-se em cada pleito eleitoral. A representação política constituiria esta cena, onde se expressam os conflitos cujos interesses afetam a sociedade em seu conjunto. Trata-se da exibição de todos os conflitos diante de todos, permitindo que a sociedade adquira sentido de unidade e de diferença. A representação política inaugura uma verdadeira cena política, ela tem o efeito de produzir a imagem da unidade e da pluralidade ao mesmo tempo.

\footnotetext{
${ }^{120}$ É importante precisar que a perda de um referencial externo (Deus, deuses) do poder não instaura um movimento inverso, capaz de alojá-lo dentro da sociedade, visto que dela emana o sufrágio popular. Na verdade, Lefort considera esse movimento do pensamento um equívoco, posto que significaria assumir que o poder apresenta um caráter encarnador, materializando-se na ideia do UM que agora passa a ser a sociedade: "O motivo que faz com que a divisão do poder e da sociedade não se remeta, na democracia moderna, a um fora imputável aos deuses, à Cidade e à terra santa, também faz com que ela não se remeta a um dentro, imputável à substância da comunidade. Ou, em outras palavras, o motivo que faz com que não exista materialização do Outro - graças ao qual o poder teria função de mediador, fosse qual fosse sua definição -, também faz com que não exista uma materialização do Um - o poder tendo então a função de encarnador. O poder não se desprende do trabalho da divisão no qual se institui a sociedade, e esta, simultaneamente, só se refere a si mesma, à prova de uma divisão interna, que se mostra, não de fato, mas, geradora de sua constituição". (PP, [1981b] 1991, p. 263)
} 
Outra característica da democracia em Lefort é a emergência de um poder paradoxal que se encontra ligado à divisão social. A competição regrada entre partidos, em que os direitos de oposição são salvaguardados durante o período em que o poder é exercido pela maioria. Podemos falar, então, de uma institucionalização do conflito, figurada pela existência de partidos políticos que exprimem, à sua maneira, os interesses e os direitos em competição na sociedade. Sofia Näsström (2006) discute esta perspectiva de Lefort sobre a representação política, ressaltando a importância simbólica da visibilidade do conflito, bem como a sua institucionalização, que previne a possibilidade de que algum grupo ou indivíduo torne-se consubstancial ao poder. Ela também aponta a vinculação entre representação, contestação e a busca permanente por um fundamento na democracia, argumentando em torno dos processos de criatividade social que podem ir além da relação representante-representado e contribuir para o engendramento de diferentes formas de representação compreendidas a partir da atuação de novos movimentos sociais. Ela chega a pensar que este cenário pode indicar que uma “nova democracia pode estar a caminho.” (NÄSSTRÖM, 2006, p. 336).

A cena política, no entanto, pode mostrar-se banalizada, isto é, apreendida como uma cena de teatro que dá a ver as facções, cujos conflitos são artificiais, cujas disputas se fazem em torno da realização de ambições particulares (cf. LT, [1986b] 2007, p. 561). A cena política testemunha um enfraquecimento da transcendência do político com relação ao social, falha que pode preparar o terreno àqueles que estão em busca de uma forte identificação, que escolhem partidos extremistas e abrem a via totalitária. Mas, enquanto subsistir uma mobilização pelos direitos fundamentais, isto é, a vontade renovada de conservar os direitos adquiridos e a reivindicação de novos direitos - que não sejam simplesmente máscaras para encobrir interesses -, os efeitos daquela cena podem ser colocados em xeque. Em face desta ameaça, o apelo a um sentido ético da democracia mostra-se necessário. Lefort sustenta, a despeito desse problema, que o lugar do poder permaneça vazio para se evitar que a vida social se petrifique $^{121}$. A desincorporação do poder, portanto, remete-nos a este entendimento sobre a representação política como busca constante pela legitimidade, como também no desintrincamento entre as esferas da lei, do poder e do saber.

\footnotetext{
${ }^{121}$ Devemos ressaltar este ponto, pois o pensamento de Lefort gira sempre em torno dessa preocupação com a petrificação da vida social, algo inerente ao totalitarismo. A noção de ideologia, por exemplo, é uma reflexão em torno de um discurso cuja marca é barrar a indeterminação, a interrogação, assumindo feições diferenciadas (ideologia burguesa, totalitária, invisível), tendo o efeito de petrificar a vida social.
} 
O que me parece mais precioso na representação política, por mais débil que esta seja em certos casos, é que faz aparecer, diante de todos, uma cena na qual se expressam os conflitos cujos interesses afetam a sociedade em seu conjunto. É precisamente devido a esta exibição dos conflitos diante de todos que a sociedade ganha o duplo sentimento de unidade e de diferença. Digo diferença e não divisões, no plural, para fazer entender que a sociedade não é, nem homogênea, nem fragmentária. Isto é o mais fecundo da representação política. (...) A representação política mantém o princípio da diferença sobre a qual se baseia a sociedade democrática. (LEFORT, 1992b, p. 142)

Convém considerar o paradoxo de um poder que é engendrado pela sociedade e que, ao mesmo tempo, se coloca como um fora, conferindo a unidade e a identidade do social; além do fato também de que tal sociedade não se reporta a si mesma a não ser se reconhecendo como comunidade pela prova constante de sua divisão (cf. LT, [1986b] 2007, p. 562). Portanto, a busca pela identidade não pode ser separada do entendimento a respeito da "desincorporação" dos indivíduos, da qual já mencionamos. A desincorporação marca a busca contínua por parte da sociedade por sua redefinição através do processo de competição política. Assim, trata-se de uma sociedade que acolhe a divisão social - já que os membros não fazem mais parte de um corpo - e o conflito político projeta-se numa espécie de encenação (mise en scène).

No primeiro caso, a nova instituição do social fundamenta-se na perda da ideia e da imagem da unidade, de tal forma que a divisão social passa a ser reconhecida como constitutiva da unidade mesma da sociedade, contribuindo para que ela acolha a ideia de conflito, que o legitime em todas as suas formas. Este, por sua vez, institucionaliza-se no plano jurídico e tem por efeito instituir "uma cena na qual o conflito se representa aos olhos de todos como algo necessário, irredutível, legítimo.” (PP, [1981b] 1991, p. 264)

A "desincorporação" dos indivíduos também confere uma nova significação para o sufrágio universal, fundado na soberania do povo. Para Lefort, esse sujeito instituinte está encobrindo "a enigmática arbitragem do Número": os indivíduos se tornam "unidades contábeis para um sufrágio universal". O número tem o efeito de aniquilar a identidade, de decompor a unidade que estava investida no corpo político, de dissolver o social.

[...] o singular procedimento do sufrágio universal, fundado no princípio da soberania do povo, porém, precisamente quando esse princípio deve afirmar sua vontade, é transformado em pura diversidade de indivíduos, cada qual abstraído à rede dos liames sociais nos quais sua existência é determinada - uma pluralidade de átomos, ou, mais 
precisamente, uma pluralidade de unidades para cômputo. Em resumo, a referência última à identidade do povo, ao Sujeito instituinte, mostra que está encobrindo a enigmática arbitragem do número. (PP, [1981b] 1991, p. 264)

Lefort está afirmando que o sufrágio universal possui uma dupla face: ao mesmo tempo em que expressa a unidade no conjunto da vontade, também manifesta a desincorporação da sociedade, dos indivíduos. Algo que está, portanto, encoberto, acessível apenas por meio do entendimento do princípio gerador dessa desintegração. $\mathrm{O}$ número impede-nos de visualizar o conteúdo, a substância da sociedade. Isto quer dizer que há uma ambiguidade inerente à noção de povo na democracia, porque, embora constitua o polo da identidade bastante definido, no sentido de que detém a soberania, é tido como aquele que é expressão de sua vontade, que o poder se exerce em seu nome, sendo invocado pelos homens políticos. Sua identidade permanece latente, sempre sujeita a um discurso que a designe, o qual, por sua vez, é múltiplo, a lhe conferir figuras diferentes, não deixa de ser dissolvido seu estatuto de sujeito no momento em que manifesta sua soberania, no ato do voto, constituindo como mais um cômputo na soma final que elege um candidato.

Assim, vimos que a democracia é uma forma de sociedade em que a esfera do político é marcada por um novo modo de legitimação, fundada no povo, detentor da soberania. Ao mesmo tempo, a imagem desta soberania associa-se àquela já discutida do poder como lugar vazio. Considerando estes dois traços, Lefort aponta que eles constituem dois princípios contraditórios: o poder emana do povo e, ao mesmo tempo, ele não é de ninguém, não podendo ser apropriado. Resolver esta contradição significa destruir, desfazer a democracia e anunciar a aventura totalitária, algo que pode acontecer se o poder aparecer como realmente vazio, ao invés de simbolicamente vazio, pois dessa forma, os indivíduos que o exercem aparecem como indivíduos quaisquer, preocupados em garantir seus interesses de classe ou seus interesses privados, alastrando em toda a sociedade esta perda de legitimidade, fazendo com que, em cada setor da sociedade - econômico, jurídico, estético, etc -, essa mesma lógica faça prevalecer o interesse individual ou corporativo. Nesse sentido, a imagem do povo permanece sujeita a ser apreendida por um partido, por facções e grupos de interesse, acolhendo uma linguagem de extrema direita ou de extrema esquerda, anunciando uma ordem nova (cf. LT, [1982b] 2007, p. 477), atualizando aquela imagem e apropriandose do poder, em virtude desta atualização. 
Dessa maneira, todas as distinções são denegadas e se estabelece o totalitarismo, cuja lógica vem a ser regida por um poder sempre arbitrário que decide e outorga e, portanto, se constitui como discurso do poder que se basta a si mesmo, ou seja, que não reenvia a uma fala que esteja fora de sua órbita.

Com efeito, se o modo de instauração do poder e a natureza de seu exercício, de modo geral a competição política, mostram-se incapazes de dar forma e sentido à divisão social, o conflito aparece como de fato em toda a extensão do social. Dissipa-se a distinção do poder como instância simbólica e como órgão real. A referência a um lugar vazio cede diante da imagem insustentável de um vazio efetivo. A autoridade dos homens que detêm a decisão pública, ou procuram se apropriar dela, se apaga para só deixar ver indivíduos ou clãs empenhados em satisfazerem-lhes o apetite de potência. A oposição dos interesses entre classes e categorias diversas, mas, igualmente, a diferença entre opiniões, valores e normas, tudo o que dá sinal de uma fragmentação do espaço social, de uma heterogeneidade, está à prova de um desmoronamento da legitimidade. Nessas situações-limite, efetua-se um investimento fantástico nas representações que fornecem o indício de uma identidade e de uma unidade sociais, e se anuncia a aventura totalitária. (PP, [1981b] 1991, p. 271, grifo do autor)

Assim, o totalitarismo surge porque há esta contradição. O que caracteriza o Estado totalitário é esta corporificação do poder em um partido e nos seus dirigentes, chegando até a se confundir com a figura do Egocrata, tal como narrada por Soljenitsin no Arquipélago Gulag (1975). Este poder incorporado condensa em si a instância do poder, da lei e do saber, erigindo-se como o local de onde os fins últimos da sociedade e as normas que devem reger as práticas sociais se fazem conhecer. O poder encarna $\mathrm{O}$ saber, disseminando a lógica de uma identificação total que busca promover a politização integral da vida de todos ${ }^{122}$.

Neste tipo de sociedade, não há espaço para o dissenso, denega-se o conflito, e busca-se a homogeneização do social, a isso Lefort denomina povo-Um, uma sociedade que nega a divisão social. Toda alteridade é expulsa, negando-se a possibilidade de diferenças de opiniões, costumes e crenças. Assim, Lefort parte do pressuposto de que o totalitarismo não pode ser considerado uma variante do despotismo, pois constitui uma nova forma de sociedade, algo que é sui generis. De acordo com Abensour (1993), a

\footnotetext{
${ }^{122}$ Apenas para retomar o que dissemos no segundo capítulo (p. 71) sobre a transcendência, podemos compreender a democracia como uma forma de sociedade que conserva traços transcendentes, como é o caso do poder que dá sinais de um fora do social para figurar sua unidade, ao mesmo tempo em que é reenviado ao povo, polo da identidade sempre sujeita ao debate. Ela também apresenta uma tendência a ser completamente transcendente, seja por meio do retorno ao discurso religioso, capaz de reinstaurar uma ordem teológico-política, seja por meio do totalitarismo, cujo discurso se caracteriza por criar o sentido de uma imanência do social.
} 
essência do totalitarismo encontra-se em seu modo de socialização original, inédito, que instaura uma nova divisão social sob a denegação do conflito. Três características lhe são marcantes: a) tendência à integração social absoluta; b) imposição de um sistema normativo hegemônico; e c) sociedade de controle total (cf. ABENSOUR, 1993, p. 89).

Para os objetivos propostos nesta tese, importa considerar estas características, assim como aquelas que já explicitamos no entendimento da ideologia totalitária e dizer que elas são sempre mobilizadas no pensamento de Lefort, em suas reflexões sobre a democracia, pois o totalitarismo está sempre no seu horizonte, tendo em vista que ele é o seu outro, um possível sempre anunciado, em virtude da possibilidade latente de corporificação do poder. Passaremos, a seguir, para a discussão central deste capítulo, relativa à questão da ideologia na democracia.

\section{Democracia e ideologia}

Com a democracia, uma nova experiência entra em curso, motivada pela nova figuração do poder, capaz de definir o povo como referencial fundamental, como polo de identidade simbólica, onde a sociedade não mais se apresenta representável através da figura do corpo do príncipe, o povo, o Estado e a nação adquirem um novo sentido, uma nova força, tornado-se polos de onde a identidade e a comunidade social adquirem seu significado. A sociedade democrática inaugura a experiência de um novo tempo, um tempo histórico por excelência, através da busca por sua identidade, algo que, para Lefort, não se separa da experiência da divisão social, pois

A sociedade democrática moderna aparece-me, de fato, como aquela sociedade em que o poder, a lei, o conhecimento se encontram postos à prova por uma indeterminação radical, sociedade que se tornou teatro de uma aventura indomesticável, tal que o que se vê instituído não está nunca estabelecido, o conhecido permanece minado pelo desconhecido, o presente se revela inominável, cobrindo tempos sociais múltiplos não sincronizados uns com relação aos outros na simultaneidade - ou nomeáveis apenas na ficção do futuro; uma aventura tal que a procura da identidade não se desfaz da experiência da divisão. Trata-se aí, por excelência, da sociedade histórica. (ID, [1979a] 1983a, p. 119-120)

Nela, instaura-se um paradoxo: a imagem de uma massa detentora de um juízo último a respeito do que é verdadeiro ou falso, bem e mal, normal e anormal, ou seja, a imagem da opinião soberana; ao mesmo tempo, a indeterminação da imagem do povo, 
em constante questionamento sobre sua identidade. Lefort compreende que a perda de um referencial último (ordem transcendente) permite uma nova apreensão da vida social. Tudo aquilo que se encontra tacitamente admitido, no domínio da atividade e do conhecimento, vê-se colocado sempre diante de novas questões e novas respostas, procurando direções divergentes. A democracia é vista por ele segundo uma ética da dúvida, em que nela há o acolhimento de uma incerteza fecunda, pois revela um necessário conhecimento sobre si mesma regido pela dúvida, pela interrogação perpetrada pelos sujeitos sociais.

A democracia é esta forma de sociedade sem precedentes, na qual se encontra, senão abandonada, ao menos colocada em xeque (en échec), a crença em uma solução dos problemas últimos da vida social, a crença em uma ordem justa e estável, conforme a natureza, ou regrada por potências sobrenaturais, em uma palavra, a crença em um bom regime. Na democracia moderna, os homens lhe parecem, em efeito, sem se dar conta disso, à prova da dúvida, enquanto indivíduos e enquanto cidadãos, no espaço privado e no espaço público - uma prova que se estabelece sobre certo agenciamento de instituições. Assim, ele considera que nada garante a perenidade desta aventura ou, em outras palavras, que a sorte da democracia permanece incerta. (cf. LT, [1993] 2007, p. 736)

Estes traços de indeterminação democrática têm sido discutidos por alguns comentadores da obra de Lefort. Miguel Abensour (2002) parte da expressão “democracia selvagem", recorrente em seus escritos, para enfatizar a ideia de que ela não pode ser domesticada, justamente porque está fundamentada segundo uma matriz simbólica, a partir da qual a síntese pode ser recusada, assim como o fundamento e a ordem, pois é concebida como o centro da indeterminação (ABENSOUR, 2002, p. 718). Ela é um "jogo de possibilidades" (ibid., p. 710), invenção contínua da política, das relações políticas, particularmente pensada sob o ponto de vista do movimento permanente de contestação por meio da demanda por novos direitos ${ }^{123}$.

Esta ausência de fundamento também foi discutida por Marchart (2007), o qual definiu Lefort como "pós-fundacionalista” (MARCHART, 2007, p. 86), no sentido de

\footnotetext{
${ }^{123}$ Leydet (1993) apresenta as discussões de Lefort sobre os direitos humanos, abordando as críticas de Ferry e Renaut à ausência de uma justificação normativa nos escritos de Lefort sobre este tema. Na perspectiva de Geenens (2008), a teoria de Lefort apresenta sim uma justificação normativa e universalista da democracia e dos direitos humanos, um debate que o autor procura estabelecer com Bernard Flynn (2005).
} 
que, embora afirme a ausência permanente de um fundamento estável, positivo da sociedade moderna - democrática - a dimensão do fundamento não desapareceu. A política na democracia, então, deve ser compreendida como "incompletude", ou seja, aquela que está sempre em busca de sua própria legitimidade e pelo sentido de suas práticas democráticas. A falta ou ausência de um conhecimento último da sociedade, de uma fundação sólida ou essência implica na noção de uma "fundação puramente negativa", pela impossibilidade de um conhecimento final que, por sua vez, abre a possibilidade de "fundações contínuas" da política que estão na dependência do conflito, da divisão social. Uma linha de discussão que é traçada pelo autor e por Einsenstadt (1998) vai no sentido de compreender a pluralidade de movimentos sociais como aqueles que procuram definir um conhecimento da sociedade e como tentativas fundacionais em competição. Há, portanto, a legitimidade de um debate movido pela interrogação que gira em torno da instituição do social, da busca por um fundamento que está sempre em falta, na sociedade democrática, e que, uma vez reconhecido, permanece como algo passageiro, ou melhor, como discursivamente atualizado, pois não se estabelece como algo definitivo. Para Einsenstadt (1998), deve-se partir do pressuposto de que a fragilidade e a instabilidade são características inerentes aos regimes democráticos modernos e que o seu campo político permanece sujeito a uma redefinição contínua através da construção de diferentes identidades coletivas e pelos movimentos de protesto ${ }^{124}$.

Outros dois autores que seguem estas mesmas observações são SteinmetzJenkins (2009) e Geenens (2008) que partem do entendimento que possui Lefort de que a democracia é uma sociedade que vive uma compreensão de si mesma no modo da incerteza, indeterminação, em que as instituições estão em crise constante de legitimação e que qualquer representação que a sociedade possa dar para si mesma sempre requer justificação.

Nos estudos citados, percebemos que, ao falar de democracia, os autores partem do seu caráter indeterminado. A exceção encontra-se nos artigos de Newman (2004) e de Plot (2012), cuja discussão aborda a possibilidade de preenchimento, ocupação do lugar vazio do poder. Com relação ao primeiro autor, encontramos uma aproximação

\footnotetext{
${ }^{124}$ No artigo de Warren (1996), a perda dos fundamentos é discutida como uma forma de responder e organizar democraticamente a política, a qual se dá através das incertezas intrínsecas desta forma de sociedade.
} 
entre Lefort e Ernest Laclau, pois Newman (2004) coloca em paralelo a noção de "lugar vazio do universal" de Laclau e a noção de "lugar vazio do poder" de Lefort, afirmando ser possível a incorporação parcial do lugar vazio.

[...] para ambos os pensadores, há um lugar ou uma dimensão política que é simbolicamente vazio e que pode somente ser articulada através de uma relação de representação contingente, em que uma identidade política particular vem parcialmente incorporá-lo. (NEWMAN, 2004, p. 152, tradução nossa)

Dessa maneira, procurando vincular os dois autores, Newman (2004) compreende que o lugar vazio articula o particular e o universal, pois uma demanda particular ocupa o lugar vazio e, com isso, ainda que nele permaneça provisoriamente, produz uma articulação discursiva com outras demandas, favorecendo, assim, seu reconhecimento como demanda universal, bem como a contestação política.

No artigo de Plot (2012), há um questionamento sobre a natureza do regime americano, com vistas a refletir se ele ainda abarca ou se reage contra a dissolução das marcas da certeza, sob o ponto de vista da institucionalização do conflito e pela ausência de um grupo que seria consubstancial ao poder. Assim, ele propõe uma investigação sobre a inter-relação entre as formas de ação dos atores políticos na sociedade americana contemporânea e sua forma política que deveria ser estruturada em torno do conflito político e do poder democrático. O autor chega à conclusão de que há falta de oposição na democracia americana, pois democratas e republicanos não realizam mais um debate e uma contestação; ao mesmo tempo, afirma que, após onze de setembro de 2001, houve uma reação à dimensão da dissolução das marcas da certeza pelo que o autor denomina como "fantasia da certeza de segurança" (PLOT, 2012, p. 57) na guerra ao terror. Com isso, o autor preocupa-se com a perda de credibilidade do regime democrático. Mais importante, em nossa perspectiva, é a afirmação do autor de que houve uma apropriação do lugar vazio do poder por parte de corporações e de setores financeiros e de grande poder aquisitivo (ibid., p. 57).

Com relação a esta observação sobre o preenchimento do lugar vazio do poder, verificamos que, enquanto Newman apresenta uma visão positiva, em Plot (2012), ela é negativa. No primeiro caso, o lugar do poder é alternado por grupos e movimentos sociais com o objetivo de requerer um reconhecimento de suas demandas políticas, já no segundo caso, ocorre a monopolização do poder e a ausência de um debate profícuo. 
Tomando como referência a nossa exposição até aqui, consideramos estas duas visões equivocadas, pois, uma vez preenchido o lugar do poder na democracia, já estamos em outra forma de sociedade e, assim, temos o totalitarismo, visto que a dimensão simbólica foi alterada por meio da encarnação do poder na figura de um homem - do Egocrata - ou de um grupo - do Partido. De certa forma, Lefort já procurou esclarecer esse tipo de confusão, ao afirmar que "não se deve confundir a idéia de que o poder não pertence a ninguém com a idéia de que ele designa um lugar vazio. A primeira pode ser formulada por atores políticos, a outra não." (PP, [1981b] 1991, p. 263). Nesse sentido, ele é "simbolicamente vazio", não sendo visível, nem passível de uma elaboração discursiva, pois ele é um princípio, uma figura que nos remete à noção de vazio e atesta que a democracia como sociedade política permanece inapreensível, sem fundamento último, sendo aquela em que "o ser do social se furta” (ibid., p. 265). Isso significa que há um questionamento permanente e um debate ininterrupto das ideologias, configurando um jogo entre incerteza e certeza, indeterminação e determinação.

Por meio da literatura mencionada acima, constatamos que a discussão permanece muito concentrada na afirmação de que a democracia para Lefort é tão somente indeterminação. Parece-nos que essa concepção deve muito ao trecho em que Lefort afirma: "O essencial, a meu ver é que a democracia institui-se e se mantém pela dissolução dos marcos de referência da certeza. A democracia inaugura uma história na qual os homens estão à prova de uma indeterminação última (...)” (PP, [1983b] 1991, p. 34, grifo do autor). Esta dissolução e indeterminação permanentes são sempre ressaltadas pelos comentadores que, no entanto, mantêm em silêncio as palavras do autor que vêm na sequência, onde afirma que a democracia é constituída pela interrogação e pelo trabalho da ideologia que está sempre destinado à restituição da certeza. Isso quer dizer que a democracia não se desprende da ideologia, justamente porque o trabalho da interrogação procura dissolver as marcas da certeza que ela insiste em estabelecer.

Dentre os autores que citamos, somente os artigos de Abensour (2002), Marchart (2007) e Steinmetz-Jenkins (2009) fazem referência à ideologia. Abensour (2002) afirma que a ideologia se apropria (to appropriate) do simbólico (cf. ABENSOUR, 2002, p. 709) para domesticá-lo, configurando uma democracia que vem a ser animada por um conflito incessante entre o simbólico e o ideológico. Nesse sentido, o autor 
considera o paradoxo de uma democracia selvagem, indomesticável, que faz a experiência de sua indeterminação, de um campo aberto para a política, mas que está sempre confrontada com as constantes tentativas de determinação operadas pela ideologia.

Na perspectiva de Steinmetz-Jenkins (2009) e Marchart (2007), a ideologia oculta e denega o lugar vazio do poder, o papel instituinte da divisão. Para Marchart (2007), através da Revolução democrática, a ideologia se constitui como "fundacionalismo epistêmico" (MARCHART, 2007, p. 103), pois ela se reveste de um discurso científico para produzir fundações últimas do conhecimento em toda esfera do social.

Nossa leitura segue a linha destes autores e também considera que a ideologia oculta e denega a matriz simbólica da democracia. Não se trata de pensar que a ideologia "ocupa" ou "preenche" o lugar vazio do poder, por exemplo, mas sim que ela produz afirmações, determinações sobre o Ser do social, responsáveis por travar e impedir o trabalho de interrogação na democracia que ocorre sempre que os agentes sociais realizam um questionamento sobre a questão-origem no trabalho de contestação, abrindo uma "brecha" na sociedade que a ideologia se encarrega de entulhar.

Consideramos não ser possível pensar a democracia em Lefort como sinônimo apenas de indeterminação, pois ela não se dissocia do trabalho, isto é, da "obra" da ideologia. É de fundamental importância uma reflexão sobre os efeitos e as consequências políticas da ideologia na democracia, pois, embora ela seja habitada pela interrogação, movida pelo princípio de invenção e reinvenção permanente, pela indeterminação, ela também se mostra petrificada, cristalizada, determinada pelo discurso ideológico. O próximo tópico mantém esta relação como centro de sua discussão.

\subsection{A (re)invenção democrática e o determinismo ideológico}

Tendo em vista o entendimento sobre a democracia, pensada a partir de duas outras formas de sociedade - a monárquica e a totalitária -, podemos agora compreender qual é a sua novidade. Trata-se de uma nova instituição do social fundamentada na desincorporação, ou seja, na "perda da eficácia prática e simbólica da 
idéia, da imagem e do nome da unidade." (CHAUÍ, 1983, p. 11). Nesse sentido, a divisão e a diferenciação social são fontes de legitimidade política, sendo responsáveis pela não petrificação do social e do político. Tudo o que foi adquirido, na esfera dos direitos e dos saberes, encontra-se na condição de sempre ser reinventado, reelaborado pelos sujeitos sociais. Como sintetiza Chauí,

A invenção democrática é um acontecimento extraordinário, 'uma revolução que corre pelos séculos', instituição do político como nova instituição do social pelo fenômeno da desincorporação, pela perda da eficácia prática e simbólica da idéia, da imagem e do nome da unidade. Advento da divisão social reconhecida como tal, da diferenciação interna entre o social e o político ou entre as esferas da existência social e a das instituições políticas, a democracia institui a alteridade em toda a espessura do social, instituindo a idéia de direitos e diferenciando, pela primeira vez, Poder, Lei e Saber 'que ficam expostos aos conflitos das classes, dos grupos e dos indivíduos e, assim, impedidos de se petrificarem'. A democracia é invenção porque, longe de ser a mera conservação de direitos, é a criação ininterrupta de novos direitos, a subversão contínua do estabelecido, a reinstituição permanente do social e do político. Como criação de direitos, como reconhecimento das divisões internas e das diferenças constitutivas do social e do político, a democracia se abre para a história no sentido forte da palavra. E desfaz as imagens da boa sociedade e do bom governo, da "comunidade ideal" transparente, virtuosa, sem conflitos, plenamente reconciliada consigo mesma, uma e invencível. Imóvel, mais do que corpo mineral. (CHAUÍ, 1983, p. 11, grifos da autora)

Todos estes traços compõem as virtudes da democracia que Lefort se encarrega de explicitar em sua tentativa de repensá-la frente às reflexões de sua época que a visam segundo uma lógica institucional e a reduzem à democracia burguesa. Tal objetivo desencadeia um entendimento sobre ela que não a dissocia do totalitarismo, pois ela carrega representações sobre o social e o político que são atualizadas por ele. De um modo geral, os comentadores de Lefort têm explicitado este viés, discutindo ainda, a relação de imbricação entre democracia e totalitarismo, perscrutando os traços que a ela são inerentes e que permitem sua passagem ao regime totalitário. O problema central, em nossa perspectiva, é pensar como os sinais de sua invenção podem ser aplacados, em outras palavras, gostaríamos de considerar que as ambiguidades inerentes à forma democrática podem ser pensadas também sob o ponto de vista da "obra" efetuada pela ideologia para impedir o profícuo trabalho de questionamento sobre si mesma que ela contém. É um questionamento que se dá em relação às suas próprias instituições, à sua própria identidade e que a abre para a história. Assim, podemos perguntar: a ideologia consegue pôr um termo ao trabalho da interrogação inerente à democracia? Ou, ainda, como pensar a democracia como questão sociológica, filosófica e histórica que tem o 
efeito de mantê-la em movimento interrogativo, se a ideologia invisível tem o efeito de produzir determinações, afirmações e certezas sobre ela, em cada domínio no qual se encontrem inseridos os sujeitos sociais?

Para respondermos a estas questões, discutiremos, primeiramente, como a ideologia ajusta-se como resposta ao caráter indeterminado da democracia, tendo em vista a desincorporação do poder e dos indivíduos, a incerteza democrática e, em seguida, consideraremos como Lefort responde às questões que formulamos.

A perda de um referencial último (ordem transcendente) permitiu uma nova apreensão da vida social. Tudo aquilo que se encontra tacitamente admitido, no domínio da atividade e do conhecimento, vê-se colocado sempre diante de novas questões e novas respostas, procurando direções divergentes. Há uma dinâmica importante na sociedade democrática que vem a ser um questionamento interminável, pois, nesta forma de sociedade, nada permanece cristalizado e sempre se elaboram novas questões a perpassar a vida em comum: ela assume uma "interrogação interminável" (LT, [1986b] 2007, p. 568).

A indeterminação que atravessa e estrutura o campo democrático gera, no entanto, efeitos ambíguos. Ao submeter os homens à prova do trágico e da dúvida, ela lhes abre um tipo de experiência que tem relação com a banalização do reconhecimento do outro, como já identificado por Tocqueville (2005) como consequência da igualdade de condições e que Lefort discute como o problema do relativismo, ou seja, a força da convicção se atenua em proveito de um pensamento que não vê em cada domínio nada além de diferenças de opiniões (ibid., p. 561). Ao mesmo tempo, identificamos o trabalho da ideologia, no sentido de fornecer uma resposta pronta e acabada aos questionamentos existentes na democracia.

A sociedade democrática, então, pode ser pensada como uma "sociedade atormentada e em constante debate" (ibid., p. 558), a qual suscita um discurso político múltiplo e uma elaboração sociológica e histórica sempre ligada ao debate ideológico, que tenta apreendê-la e, ao mesmo tempo, efetuar uma dada representação do Estado, do povo e da nação. Lefort menciona que não foi por acaso que a ideologia burguesa exerceu um discurso nos primeiros tempos da democracia que buscava resistir à ameaça de decomposição da sociedade como tal. 
A tentativa de sacralização das instituições pelo discurso é comensurável à perda da substância da sociedade, da derrota do corpo. O culto burguês da ordem, que se sustenta com a afirmação da autoridade, com suas múltiplas figuras, com o enunciado das regras e das justas distâncias entre os que ocupam a posição do senhor, do proprietário, do homem cultivado, do homem civilizado, do homem normal, adulto, face ao outro, todo esse culto testemunha uma vertigem perante a voragem de uma sociedade indefinida. (ID, [1979a] 1983a, p. 119)

A ideologia na democracia é sinal de suas ambiguidades. De acordo com Lefort, o trabalho da ideologia não consegue pôr um termo à democracia ou, em outras palavras, em seu trabalho destinado como está à restituição da certeza, não consegue impedir que nasça a incerteza que anima este regime (cf. LT, [1983b] 1991, p. 35). Assim, o trabalho da ideologia não coloca um fim ao trabalho da interrogação que anima a democracia, de modo que não apaga o trabalho feito pela revolução democrática, isto é, a destruição dos fundamentos de legitimidade e de verdade.

Não se trata de pregar a destruição do discurso ideológico, isto Lefort não faz, porque recairia na utopia marxista. Ele considera que a ideologia sempre existirá, continuará seu trabalho sobre a democracia, sua obra - palavra que nos dá a noção de que há certezas partilhadas pelos sujeitos sociais, as quais, no entanto, não chegam a impedir completamente o exercício da dúvida, das interrogações que alimentam a crítica e os reenviam ao discurso instituinte. Nesse sentido, ocorre a fundação constante da política, da sociedade política, pois ainda que a ideologia procure determinar o pensamento do homem democrático, Lefort considera que ele é trabalhado pela incerteza e todo o saber ideológico que possui, permanece vinculado ao não-saber, isto é, aos "possíveis", ao "talvez" que abre uma carreira para a indeterminação democrática.

Pouco importam todos os meios postos por obra da ideologia dominante a fim de impor os novos critérios de julgamento social; por maior que seja sua eficácia, eles não podem apagar definitivamente o trabalho feito pela revolução democrática, isto é, a destruição dos fundamentos de legitimidade e de verdade. Quando é definido como independente, o indivíduo não troca, como parece supor Tocqueville, uma certeza por outra - a que derivaria no presente de sua autonomia, ou então, inversamente, a que o faria se arrimar ao poder da opinião ou ao poder da ciência. Ele está destinado a continuar sendo em surdina trabalhado pela incerteza. Desde que a verdade não poderia se desprender do exercício do pensar, desde que o direito, em virtude do qual o indivíduo é afirmado, mostra-se ligado à sua própria faculdade de enunciá-lo, saber e não-saber se combinam sem que se possa jamais separá-los. E mesmo esta distinção entre pensamento e direito não dá conta da novidade do acontecimento, pois o exercício do pensar modifica-se quando é afirmado um direito de pensar, direito 
indefinido, por certo, mas que leva sempre mais longe o que era outrora afeito ao interdito. Tal direito não se circunscreve aos limites do político; concerne todas as relações que o indivíduo mantém com o mundo, com outros, consigo mesmo, concerne todos os seus pensamentos, funda-os, no mesmo momento em que os faz advir. (PP, [1982d] 1991, p. 213-214, grifo nosso e grifo do autor)

A democracia é uma forma de sociedade que assume uma interrogação interminável, sendo, para Lefort, uma sociedade filosófica ${ }^{125}$, mas que, ao mesmo tempo, as questões que formula estão sujeitas a serem apreendidas pelo discurso ideológico, na medida em que ele procura impedir este trabalho de interrogação, pela elaboração de respostas que têm o efeito de recobrir o profícuo exercício da dúvida, criando determinações para a prática democrática. É por isso que ela deve manter-se em estado de interrogação permanente, ou ainda, como "democracia selvagem", segundo Abensour (2002) procurando sempre escapar à ideologia.

Na realidade, eu creio que a sociedade democrática, se ela se arrisca de se deteriorar nas divisões de fatos e de interesses ou de cair num relativismo e num niilismo, é aquela também que é a mais exigente e a mais filosófica, porque é nela que os fundamentos da lei, do poder e das relações sociais são objeto de um "colocar em questão" contínuo. (LT, [1986b] 2007, p. 563)

Nesse sentido, podemos pensar na relevância de uma ética da dúvida, isto é, de um trabalho constante de interrogação que seja responsável por colocar em contradição o discurso ideológico. A interrogação, a qual se refere Lefort, não se dissocia de uma análise das relações sociais, da divisão social, do discurso que as articula e oculta, isto é, da ideologia. (cf. LT, [1988] 2007, p. 602) Somente dessa forma pode-se impedir que a sociedade democrática se petrifique no discurso ideológico.

Nessa perspectiva, a ideia de interrogação deve ser explicitada, pois ela se diferencia daquela tagarelice sábia ${ }^{126}$. Na democracia, há a liberdade de falar, de dar opiniões, mas há uma diferença importante a ser pensada: pode haver uma linguagem interrogativa, capaz de colocar a ideologia em contradição, como também uma "falsa crítica". A grande questão, então, passa a ser o tipo de reflexão, a natureza do discurso interrogativo que deve ser mantido na democracia capaz de colocar a ideologia em

\footnotetext{
${ }^{125}$ A democracia é uma sociedade filosófica, na perspectiva de Lefort, porque ela se dá como questão, como interrogação interminável sobre seus próprios fundamentos.

${ }^{126}$ Esta tagarelice sábia pode ser entendida como o discurso competente, conforme definido por Chauí (2008).
} 
contradição. Acreditamos que se trata, efetivamente, do discurso sobre o político, concebido por Lefort em seus trabalhos.

O próximo e último capítulo parte deste pressuposto, ou seja, de que, no pensamento de Lefort, a ideologia não consegue impedir o trabalho da interrogação e, portanto, da invenção democrática, mas este trabalho, por sua vez, encontra-se na dependência de uma ética da dúvida, de um discurso interrogativo que seja um discurso contraideológico. 


\section{CAPÍTULO 5 - Crítica e ideologia}

\section{Introdução}

Nos capítulos anteriores, vimos que a ideologia não pode ser completamente destruída na sociedade histórica, pois ela é tão originária quanto o discurso instituinte, ou seja, ela nasce e renasce constantemente, constituindo um debate ininterrupto e movediço, visto que as ideologias visam oferecer, em cada época, um fundamento determinado para o social, apresentando-se como discurso sobre a política. Tendo em vista que ela contém esse caráter inextirpável e, ao mesmo tempo, mutável, gostaríamos de discutir como Lefort concebe sua crítica à ideologia. Para realizarmos essa discussão, faremos um novo desvio que nos remete ao significado da "obra de pensamento", pois ela tem o caráter de um discurso crítico (LTO, 1986c, p. 16), capaz de desvelar ou desselar a ideologia.

Adquire centralidade, então, o trabalho de interpretação que está contido na obra, uma vez que o autor tem a possibilidade de criar uma linguagem crítica pelo fato de ser intérprete de seu tempo, mantendo seu pensamento entrelaçado com o discurso de outros autores - contemporâneos seus ou de seu passado - e com a própria ideologia. É nesta implicação de discursos, ou melhor, na complicação (complication) discursiva que a crítica pode nascer, pois ela nada mais é que uma "abertura" (ibid., p. 58) a ser estabelecida pelos sujeitos sociais em cada aqui e agora e que pode ser entendida como o momento da verdade (CA, [1971a] 1978f, p. 137). Isso significa que a verdade está escondida e requer uma busca, um trabalho de interpretação, de interrogação e de contestação em relação à ideologia face às exigências do presente, capaz de recolocar os sujeitos em contato com o discurso instituinte.

Dessa maneira, a crítica não pode ser compreendida como um discurso que se contrapõe ao discurso ideológico pela afirmação de uma tese oposta, como discurso categórico, mas como aquele que desconstrói os enunciados, as representações, que revela as contradições da ideologia, pois se mantém no modo interrogativo, pelo fato de que restabelece o laço com a questão-origem ocultada por ela. 
O capítulo finaliza apresentando o pensamento do político para Lefort, argumentando que ele pode ser compreendido como pensamento crítico da ideologia.

\section{A obra de pensamento e a ideologia}

O que é obra de pensamento para Lefort? Podemos responder esta pergunta a partir da própria fala do autor que a designa por aquilo que ela não é: "nem obra de arte, nem produção da ciência, que se ordena em razão de uma intenção de conhecimento e à qual, no entanto, a linguagem é fundamental” (FH, [1970a] 1979b, p. 155). Essa resposta, dada logo na primeira frase de seu artigo "A obra de pensamento e a história" (1970a), tende a nos colocar em suspensão, à espera de uma definição mais precisa que, talvez, pudesse abarcar, inclusive, algum tipo de conceituação. Tal espera, no entanto, ainda que seja sustentada pela intenção de conhecer mais profundamente a noção destacada pelo autor, está sujeita à decepção, pois o que faz Lefort é justamente nos reenviar à experiência que se dá com a leitura, em que está pressuposta uma interlocução de pensamentos entre o escritor de outra época e o leitor que o lê em seu tempo presente.

É somente no bojo desta experiência que se adquire o significado da obra de pensamento, pois ela não é vista por ele como "coisa em si" (FH, [1970a] 1979b, p. 156), nomeada de antemão e limitada a seu próprio tempo, mas está na dependência de um trabalho de pensamento que vai até ela e a toma em suas mãos, sabendo que sua identidade encontra-se na dependência deste movimento e da experiência da leitura que não se desprende de cada aqui e agora. É por isso que a obra de pensamento permanece como questão à espera de seu leitor, pois ela "nada é fora do movimento que leva até ela" (ibid., p. 156). Isso significa que a obra de um pensador mantém-se indeterminada e contém uma abertura indefinida ao diálogo com seus leitores próximos e com aqueles distanciados no tempo, pois sua identidade não está dada, estando sempre na dependência da interrogação de seu leitor.

Uma interrogação que não está somente nele, mas é incitada pela obra que a faz nascer em seu leitor, pois toda vez que este se pergunta o que ela é, esta questão não nasce distante da obra, fora dos seus muros, mas no seu interior, no enlace de pensamentos que ocorrem com a leitura. Trata-se de um cruzamento de questões abertas 
pelo próprio escritor e que se articulam com as questões, os motivos e as intenções do intérprete em sua prática interpretativa. Dizer, como o faz Lefort, que a obra suscita e faz nascer em seu leitor uma questão, implica, ao mesmo tempo, considerar que ela é feita de um discurso sui generis, justamente porque não se reduz à forma demonstrativa, a respostas que, desprendidas das interrogações, lançam um saber conclusivo sobre o social e sobre a História. É por se dar como discurso interrogativo que a obra abre uma carreira indefinida à interrogação e às interpretações.

A resposta à questão inicial leva-nos, por conseguinte, a um desvio que não é casual, porque, se tivéssemos a sua definição não compreenderíamos o que está implicado no discurso da obra e no jogo da interpretação: uma abertura para pensarmos a elaboração, o estatuto crítico e a linguagem de um discurso capaz de desvelar a ideologia $^{127}$.

$\mathrm{Na}$ linha de Lefort, consideramos que essa linguagem crítica se exprime como linguagem literária, pois pode ser entendida como "pura prosa" enquanto significação que capta aquilo que nos é familiar e nos remete a uma experiência comum, de tal forma que somente o sentido se pronuncia e a "verdade da coisa se manifesta" (LTO, 1986c, p. 48). Essa linguagem também é simbólica como um poema, pois não pode ser racionalista, determinista, demonstrativa com vistas a colocar "as coisas a nu" (ibid., p. 70), enquanto objetos que são vistos em sobrevoo. O que o poeta faz é procurar se evadir do fantasma de fechamento que está sempre a rondar a sua fala e que a aprisiona, exigindo de sua parte uma revolta interna, a sua insurgência contra a palavra que sempre é dobra de si mesma, apresentando-se sob um sentido definido, determinado, como certeza que não o coloca à prova de si mesmo. Essa insurgência contra a linguagem dobrada é entendida como insurgência contra o real enunciado, pois o escritor-poeta não se submete à ordem do mundo como "ordem instituída das coisas" (CA, [1966b] 1978f, p. 167), pois é aquele que "entrevê a margem que separa o real e o indeterminado" (ibid., p. 167). Ele está sempre em estado de desconfiança (en suspicion), em constante dúvida e seu escrito tem o efeito de abalar a nossa fé no real através de um trabalho de mimese do discurso que dá sustentação ao real, isto é, da ideologia. Essa recriação do suposto real retém figuras, articulações para abalar a crença e o saber que são mantidos

${ }^{127} \mathrm{O}$ discurso dos intérpretes da obra, na perspectiva de Lefort, é aquele, portanto, que deve sempre ser retomado no estudo de qualquer escritor, autor, filósofo, pois neles podemos distinguir os traços de certas circunstâncias históricas e ideologias que influenciaram a leitura do intérprete. Ao mesmo tempo, aquele discurso "dá a pensar" o discurso do escritor, "atesta a presença da obra" (cf. FH, [1970a] 1979b, p. 158). 
pelo discurso ideológico, através da ironia (dérision) que reconduz ao sentimento do trágico e produz o estranhamento para nos desfamiliarizar com a representação, pois criam uma desordem. De acordo com Mouchard (1993), certos poemas contêm versos que sabem se ligar, intuitivamente, a momentos onde a lei torna-se indeterminação, pensando certos ritmos e acontecimentos da vida coletiva de maneira sensível através de eclipses, interrupções, saltos e, nesse sentido, eles são capazes de "iluminar as representações" que assombram a sociedade (MOUCHARD, 1993, p. 276). O que significa, segundo este autor, que a leitura da obra e a leitura da sociedade se valem dos mesmos princípios, estando regidas pelo mesmo discernimento: abandonar o ideal de um pensamento e de uma linguagem puras, pois são ilusões que perseguem o falar e o pensar filosófico e político (ibid., p. 264).

A linguagem literária nos permite pensar a crítica como aquela que faz surgir um novo discurso que provoca vertigens no seu leitor, porque abala a noção que acredita ter do real, transformando o conhecido em enigma, em questão, em interrogação. O pensamento em estado interrogativo é o "impensado", o não-ainda que se mantém como "talvez" (peut-être) e anuncia possíveis que nascem com a interpretação. A crítica é este impensado que cria um lugar para a "ausência" ocupar, pois há algo que permanece em espera, como aquilo que ainda não veio, como o "nãorealizado-ainda"(CA, [1966b] 1978f, p. 172) ${ }^{128}$, como o não-saber que até então não se sujeita às normas do suposto real. Trata-se da "abertura" (ibid., p. 173) para possíveis, para uma "passagem"(ibid., p. 172) que se busca no mundo dominado por respostas e por certezas ideológicas. Como afirma Lefort, é preciso que se faça o "enterro do seu saber" (FH, [1978c] 1979b, p. 15), isto é, do saber de sobrevoo, uma ação que resulta em um aprendizado que nada mais é que a chegada de um novo saber.

O crítico deve agir como o escritor literário, não podendo produzir, nem criar uma nova verdade como ponto de vista de certeza, mas abalar a crença e desagregar o objeto através de uma fala que permanece como "esboço" (ébauche), pois realiza o

(...) trabalho de destruição do estabelecido, de corroer as crenças e de desagregar o objeto. Disso resulta também que ela se mantém sempre nos limites do esboço, pois

\footnotetext{
128 Lefort realça o que para Michaux constitui uma rica experiência: o tempo da interrogação característico da infância como a "era de ouro das questões", uma vez que é de respostas que o homem morre (cf. CA, [1966b] 1978f, p. 172). O que significa, na discussão que estamos fazendo, que a vida política nas sociedades democráticas é feita de interrogações e não de modelos e de fórmulas ideológicas que nos são oferecidas sobre ela.
} 
ela só vale por seu movimento de insubmissão contra o real, de romper a ordem do tempo assim como aquele do espaço. (CA, [1966b] 1978f, p. 172)

Isso quer dizer que, quando Lefort fala de instituições, de acontecimentos, da história, da ordem e da desordem, de certas condutas, dos conflitos, da contestação, ele nos remete a certo mundo, a um campo, a um espaço que é pensado pelo escritor, pois é trabalho que modifica, desloca ou arruína as significações adquiridas para fazer emergir aquilo que estava recoberto: o político na sociedade moderna. A construção de sua própria linguagem se manteve atrelada à linguagem literária e procura manter-se em estado interrogativo, lançando mão de tons irônicos e criando desvios em relação às falas ideológicas de sua época. Sua relação com a literatura não se reduz a interpretar certos escritores - Soljenitsin, Orwell, Stendhal, etc. - mas também reflete a escolha por um estatuto para sua filosofia, pois Lefort prefere nomear-se "pensador-escritor" (DEP, [1992e] 1999a, p. 13) e mantém a opção por uma escrita que, da mesma forma que a literária, busca se manter como linguagem "instituinte" (CA, [1966b] 1978f, p. 164) ${ }^{129}$, isto é, como interrogação permanente através de seus inúmeros artigos.

A linguagem crítica como desvelamento é irônica, contém a veemência de um tom ou uma reserva imprevista, contém reversões para gerar dúvidas ou, ainda, uma questão insistente, ao mesmo tempo em que chama seu leitor a tomar a palavra, a adentrar no seu recinto e tomar a via de um discurso crítico, pois dá a pensar significações que fazem “vacilar a noção de real” (cf. LTO, 1986c, p. 55).

O discurso que critica a ideologia é aquele que dá a pensar, pois cria as condições para ocorrer o "acontecimento do pensamento", faz com que a palavra tornese "acontecimento" mantendo-se atrelada ao "já-pensado" da ideologia e com o aindanão pensado que está por vir e que anuncia possíveis, pois, para Lefort, “o pensamento vivo é crítica" (cf. LT, [1992c] 2007, p. 703). Neste cruzamento que vem a ser uma "complicação de discursos", ocorre o acontecimento do pensar que pode ser compreendido como o momento da abertura, da verdade que se estabelece em cada aqui e agora. O discurso da obra, como discurso de desvelamento, é aquele que nos coloca em condições de pensar a história como aquela que sempre se mantém e se refaz, pois o

\footnotetext{
${ }^{129}$ No artigo "Filósofo?" (1985), Lefort reflete sobre sua própria filosofia como aquela que se manteve ligada a obras historiográficas, etnológicas, literárias como um pensamento não dividido e não apartado de outros campos de conhecimento: "Filosofia, não-filosofia? Como traçar uma fronteira? Certamente, eu não era o primeiro a indagar. Porém, parecia-me insuficiente responder que pode haver mais filosofia num livro de história, num trabalho de política, num romance ou num poema do que num tratado que leva esse nome."(DEP, [1985] 1999a, p. 345)
} 
presente, o passado e o futuro mantêm uma relação de parentesco, no sentido de que é consubstancial a um tempo, ou melhor, que ao falarmos em divisão de classes, da divisão do Poder e da Lei, do Estado e da sociedade civil, do real e do imaginário, estamos tratando de variações que ocorrem no tempo, mas também permanecem e nos fazem gravitar em torno do "Mesmo" (LTO, 1986c, p. 65).

Nesse sentido, o pensamento que decifra a ideologia é aquele que se dá "na forma de obra", ou seja, é o lugar de um trabalho de metamorfose e de instauração, pois não se afirma ao lado da ciência ou da filosofia política, nem da arte, nem do discurso demonstrativo, mas procura relacioná-los para "dar carne à experiência do ser" (ibid., p. 67). Isso significa que ele se dá no modo interrogativo e arranja um espaço para o indeterminado em relação à linguagem determinista da ideologia. Ao mesmo tempo, também implica em "reformular", ou seja, em interpretar a ideologia enquanto "fórmula", buscando desfazê-la, desconstruí-la para que a interrogação que nela está camuflada apareça.

Além disso, ele cria uma cena (scène) que não pode ser compreendida como ficção, mas que procura rearticular as personagens, os atores políticos na relação que mantêm com outros protagonistas (cf. LTO, 1986c, p. 67), a fim de liberar um sentido, alcançando uma função simbólica, uma significação capaz de colocar a ideologia em contradição.

Nesse sentido, todos os deciframentos da ideologia praticados em diferentes tempos históricos se mantêm articulados, em uma relação de parentesco, pois elas orbitam em torno do "Mesmo" e se ordenam em um campo simbólico, uma vez que interrogam o "ser do social".

No âmbito desta reflexão devemos averiguar o que teria propiciado a elaboração do discurso da obra, isto é, o que teria levado certos escritores a conseguirem interrogar seu próprio tempo a ponto de abrir uma nova leitura crítica das ilusões em que se achavam presos os homens de sua época e, no mesmo movimento, fundar uma nova interpretação sobre este mundo? Em resumo, por que ele conseguiu desvendar a ideologia de sua época e outros contemporâneos seus não? A resposta a essas indagações é de fundamental importância para pensarmos as condições em que a crítica à ideologia pode nascer e se desenrolar. 
Em certa medida, o surgimento da crítica não se desprende da própria natureza do discurso ideológico, um discurso que é incapaz de produzir um recobrimento total, de modo que sua própria linguagem está sujeita à contradição, por constituir incongruências em sua fala, em relação às quais o trabalho da interrogação pode provocar a contradição e fazer a ideologia aparecer como mentira. Ao mesmo tempo, para que a ideologia entre em contradição, torna-se necessária a percepção das lacunas inerentes ao social, a qual depende de um trabalho, cuja particularidade nos remete ao entendimento do intérprete.

O intérprete é leitor da obra de pensamento, podendo produzir um saber sobre ela capaz de afirmar a sua verdade, de "selá-la" em um julgamento (cf. LTO, 1986c, p. 32). O escritor desta obra, no momento em que escreve, também se constitui como intérprete, pois a instauração de seu discurso mantém uma relação com discursos-outros dos quais o seu se nutre, discursos de autores do passado ou contemporâneos e com o discurso ideológico de sua época. A interpretação, portanto, ocorre nesta imbricação de discursos, podendo ser entendida de acordo com duas perspectivas, na linha das reflexões de Lefort, sendo uma delas crítica - o intérprete-escritor da obra de pensamento - e a outra ideológica ou determinista - o intérprete como um ideólogo.

A primeira pode ser ilustrada como aquela desenvolvida pelo escritor de uma obra de pensamento que realiza uma leitura crítica sobre os fatos políticos de sua época e produz um novo discurso contraideológico. Trata-se de uma interpretação que articula os discursos coletivos de seu tempo e aqueles de outros autores, como o fez Maquiavel, na leitura de Lefort (1986c) e que tem o efeito de reenviar o pensamento em contato com o instituinte, isto é, repassando e reelaborando a questão-origem e, no mesmo movimento, abrindo novamente para possíveis interpretações. Cabe ao leitor produzir uma nova verdade sobre a obra e procurar apresentar a sua identidade - o que ela é - no futuro. Ele poderá fazê-lo, de acordo com Lefort, na mesma linha crítica seguida pelo escritor ou, por outro lado, em um viés determinista.

A segunda forma de interpretação alimenta-se de um desejo de determinação e procura visá-la como um objeto, a fim de afirmar o que ela é segundo sua tese de leitura. Para tanto, ele fragmenta e recorta o discurso do escritor a fim de retirar os trechos que melhor se acomodam ao seu ponto de vista, ou seja, busca apenas respostas para construir uma lógica análoga àquela da demonstração. Dessa maneira, assinala-se 
um projeto de domínio, pois este leitor hierarquiza os enunciados presentes na obra e os reordena segundo sua perspectiva, uma operação que denega as contradições presentes na obra ou as vê como erros, equívocos cometidos por parte do autor. Além disso, este intérprete instala-se em uma posição determinada, a fim de sobrevoar o discurso do autor, como se pudesse estar longe do discurso da obra e do lugar onde ela apareceu, uma posição que Lefort denomina como "política" (cf. FH, [1970a] 1979b e LTO, 1986c), pois o intérprete exerce um poder ao arrogar um certo saber sobre a obra que tem a função de obter o consenso dos leitores e fazer reconhecer a legitimidade de sua interpretação. O intérprete está sujeito à grande tentação de "ocupar a posição do poder absoluto", pois divide o discurso, o tempo em que o discurso do autor foi produzido como aquele que pertence ao passado, além de produzir a separação plena do discurso com o real. Essa postura interpretativa é atribuída àqueles intérpretes da obra de pensamento que concluem um saber sobre a obra, fechando-a em torno de um sentido determinado por sua tese de leitura.

Em nossa perspectiva, estas reflexões de Lefort sobre a interpretação da obra de pensamento contêm, em suas raízes, um entendimento sobre a crítica da ideologia pelo trabalho da interpretação. Esse trabalho está no cerne da ação política e ocorre no limiar estreito de duas leituras possíveis, uma delas crítica - o discurso da obra é exemplar enquanto discurso contraideológico -, e a outra ideológica ou determinista que concebe uma representação ideológica da obra de pensamento. Este último tipo de intérprete pode até criar um novo discurso, mas acaba por reproduzir a ideologia, em uma espécie de sobrerrepresentação ideológica.

Estamos particularmente interessados em discutir não apenas a natureza do discurso crítico, mas também o que faz com que, neste limiar estreito, a interpretação deslize para uma destas duas vertentes. Iniciaremos pela interpretação para chegarmos ao discurso da obra e traçaremos sua distinção em relação à ideologia, tendo em vista 0 trabalho do intérprete para aprofundar a posição afirmada acima.

\subsection{O intérprete e a ideologia}

A interpretação constitui-se como o trabalho de interrogar discursos-outros, estando implicada na própria linguagem que se institui com o pensamento. Dessa maneira, nós consideramos que este trabalho, em princípio pensado por Lefort com 
relação à obra de pensamento, contém em si o exercício da interrogação que os homens podem vir a estabelecer com a ideologia. Veremos, então, de que modo ela pode se dar e o risco que conjura ao manter-se como crítica, como desvelamento e deciframento sem fazer coro à ideologia.

O ponto de partida desta discussão é a interpretação de Lefort sobre a obra de Maquiavel em Le travail de l'oeuvre Machiavel (1986c), resultado de sua tese de doutoramento, na qual procura discutir o caráter emblemático desta obra que fora alvo de diversas interpretações não apenas pelos seus estudiosos [de Maquiavel] (que são muitos), como por políticos. Assim, vê-se a propagação indefinida de termos como "maquiavélico" e "maquiavelismo" que já fazem parte da linguagem comum, de tal forma que se criou um julgamento sobre a ação de Maquiavel, sobre suas ideias e sobre sua qualidade de homem político e de escritor.

Esse discurso que se elabora na posteridade de um autor, revela que nós, contemporâneos, estamos envolvidos em um conjunto de representações que nos informam quem foi determinado autor: por exemplo, o discurso de Platão, como aquele que fez nascer o discurso filosófico; ou, ainda, o de Hegel e de Marx, um discurso sobre a História como tal. Assim, essas representações nos apanham e nos dominam, tanto na visão positiva como na negativa sobre o discurso de um autor; o que significa dizer que a obra é apanhada em representações e que para a compreendermos não podemos simplesmente colocá-las de lado, mas tomá-las como ponto de partida no trabalho de seu entendimento. Isto se deve ao fato de que Lefort compreende que, no discurso dos intérpretes, há uma tentativa de dominar a obra, dizer o que ela é, sendo comandada por uma afirmação primeira que reside na tese de leitura do intérprete. Para confirmar suas hipóteses, o intérprete utiliza-se da obra como objeto, recortando-a, colocando em destaque certos enunciados e desprezando outros, recusando os trechos que não se encaixam nos argumentos que detém sobre ela. Na esteira deste movimento, o entendimento da obra não se dissocia da compreensão daquilo que é denegado pelos intérpretes e que reenvia ao discurso do autor.

Ao sondar o que permanece apagado na obra, invisível aos olhos dos intérpretes, Lefort se dá conta de que Maquiavel, embora não tenha utilizado o vocábulo "ideologia" - um uma vez que o termo não havia sido ainda nomeado como tal e seria 
absurdo procurar encontrá-lo em meio a suas palavras -, estabelece um contradiscurso que procura reverter as posições instituídas na matriz do humanismo político.

Em razão de dificuldades encontradas na compreensão do Príncipe e dos Discorsi, pareceu-nos que a interrogação da história e da política achava-se ligada à crítica das idéias dominantes do tempo e que estas revelavam, em seu núcleo, o pensamento político dos humanistas, formado um século antes. (FH, [1973] 1979b, p. 255)

Nas discussões que Maquiavel procurou colocar em relevo sobre a divisão das classes, a divisão do Estado e da sociedade civil e, ainda, da diferença dos tempos, como salienta Lefort, figurada na Roma antiga e na Florença moderna (FH, [1973] 1979b, p. 255), ao suscitar uma reflexão sobre a história e a política em geral, podemos identificar a articulação de um pensamento que procura decifrar os discursos coletivos de seu tempo.

Lefort identifica, no discurso de Maquiavel, na vontade que expressa em termos de uma aproximação do real como tal, a realização de uma crítica às ilusões de que eram tomados os homens de sua época, dos mitos que mascaravam o acesso ao mundo e a das condutas imaginárias que embaralhavam as linhas do presente ${ }^{130}$. Assim, compreende que Maquiavel dirigiu-se às massas de seu tempo, à burguesia ascendente de Florença que permanecia enfeitiçada pela tradição moral e religiosa na figura de Soderini, homem de Estado sem virtù, paralisado por escrúpulos morais, incapaz de opor a violência à dos adversários.

Não nos aprofundaremos em todas as observações que Lefort desenvolve sobre Maquiavel, mas é importante salientar que, neste estudo, ele reconhece a diferença entre o discurso da interpretação e o discurso da ideologia (LTO, 1986c, p. 775). A interpretação que possui Maquiavel de sua época pode ser considerada emblemática, pois é discurso de desvelamento, de deciframento da ideologia. Sublinhamos essas palavras porque nos levam a um entendimento da interpretação estabelecida por Maquiavel $^{131}$, não como a criação de um novo discurso que oferecia teses novas, em

\footnotetext{
${ }^{130}$ Em um artigo, intitulado "Reflexões sociológicas sobre Maquiavel e Marx: a política e o real" ([1960b] 1979b), Lefort realiza uma aproximação entre Maquiavel e Marx, considerando-os como críticos de seu tempo, comunicando-se pela mesma intenção realista presente em seus escritos. Ele discute o papel deste pensamento - realista - que vem a ser um momento necessário no advento da realidade como tal, em que se destacam os imperativos da ação aos quais os homens deveriam se submeter.

${ }^{131} \mathrm{E}$, também, como veremos, da ideologia de um modo geral, porque o contradiscurso ideológico não produz um novo discurso, em termos de uma nova verdade que se coloca frente à ideologia para acusar
} 
contradição com aquelas que eram comumente partilhadas por seus leitores, mas pelo fato de que liberava para o pensamento um poder de interrogação, isto é, o que ele fazia era assinalar, colocar em relevo o que foi eludido pela ideologia. Ele desvelava o que permanecia interdito ao pensamento, o que não podia ser pensado, porque a ideologia recobre a ordem política, sendo sustentada por proposições agenciadas como teses sobre o social, para impedir que se pense a divisão social e a divisão temporal.

Assim, a crítica maquiaveliana adquire uma importante significação para pensarmos o tipo de discurso crítico que ocorre em relação à ideologia. Em primeiro lugar, este discurso não se separa da ideologia, não pode produzir um saber sobre ela enquanto saber de sobrevoo, porque seu próprio pensamento é dela devedor e dela não se separa inteiramente ${ }^{132}$. Há um momento de quase-separação, mas que não se cumpre efetivamente porque o discurso crítico a tem como substância do qual parte para apontar suas incongruências, suas discordâncias, as fraturas que assinalam o que foi eludido. Neste movimento, por sua vez, destacamos que o discurso crítico não pode residir na afirmação daquilo que é a ideologia, a não ser reconstruindo na linguagem aquilo que estava acomodado no balbucio, em semissilêncio, o que não é dito inteiramente, o argumento que está apenas em parte na ideologia, constrangendo-a a falar. O intérprete crítico, então, constrói este novo discurso revelador, decifrador e reenvia seu leitor a reconhecer a ideologia e, principalmente, aquilo que está latente, invisível na linguagem ideológica. Nesse sentido, ele não produz novas verdades que contradigam a ideologia e que sejam, então, colocadas no seu lugar. O que ele faz, por sua vez, é revelar a denegação e reenviar o pensamento ao que estava oculto e não se pensava. A crítica, portanto, tem a finalidade de fazer pensar e, para isso, sua linguagem deve se manter na forma interrogativa, apresentando em si mesma uma questão-origem (LTO, 1986c, p. 720), isto é, um tipo de questão que está contida no discurso da obra, no ser do social e que vem a ser aquela que é aberta e que "dá a pensar o que ainda não tinha sido pensado", suscitando, no seu rastro, outras questões, marcando um pensamento que se instaura como movimento interrogativo (cf. FH, [1974] 1979b, p. 314).

\footnotetext{
sua mentira, mas sim, requer um deciframento, um desvelamento, ou seja, um modo de rearticulação dos enunciados da ideologia que são responsáveis por colocá-la em contradição.

${ }^{132}$ É por isso que Lefort afirma que a ideologia está no fundo de nossos pensamentos e que, ao desvelá-la, estaremos desvelando a nós mesmos. Ele afirma que "ela não é simplesmente interposta como uma tela entre nós e as coisas, mas se acha impressa no fundo de nossos pensamentos e todo esforço para desvelar o que é implica um desvelamento de si para si mesmo." (FH, [1978c] 1979b, p. 20).
} 
Como vimos, a ideologia tem o efeito de produzir um pensamento sobre ela que pode ocorrer por meio de comentários, exegeses e interpretações, que podem se dar na linha crítica que discutimos acima, como também numa espécie de "réplica ideológica", produzindo comentários infinitos que, na verdade, não nos reenviam ao discurso instituinte em que o social e o Histórico ocorrem como questão nas sociedades em que passou a haver a quebra da ordem transcendente. Eles não nos reenviam àquilo que foi recoberto pela ideologia, isto é, ao discurso instituinte. Podemos exemplificar algumas modalidades deste discurso não-crítico da ideologia, mas que mantém a "aparência" de uma crítica.

Referimo-nos àquilo de que já falamos no capítulo três: uma tagarelice sábia (bavardage savant) sobre a ideologia. Assim, temos um discurso sobre o que é a ideologia - pensamento da ideologia - que, na perspectiva de Lefort, pode não dizer nada sobre ela, pois não a coloca como questão, uma vez que não a reenvia ao seu núcleo: a divisão social. E não a compreende sob o ponto de vista de uma clivagem entre a ordem da prática e a da representação. A condição deste debate, como explicitado por Lefort, na introdução de seu artigo "Esboço de uma gênese da ideologia nas sociedades modernas" (1974), lhe parece ser marcada pela "degradação do conceito de ideologia" (FH, [1974] 1979b, p. 296) ${ }^{133}$.

Ao considerar o debate sobre a ideologia, Lefort aponta que alguns permanecem denunciando a decomposição da ideologia burguesa, enquanto outros, numa perspectiva diferente, inscrevem todo pensamento no registro da ideologia, contribuindo para o reino das confusões no que tange a esse tema. Cada ator, cada grupo específico, em certas condições (sociólogos, militantes, certos grupos políticos) parecem compreender a ideologia e usá-la de modos diferentes. Em consequência, Lefort aponta três tipos de compreensão sobre ela: a) a primeira, considera o fim da ideologia, cujo ponto de partida reside na sua identificação a um projeto global de transformação da sociedade proveniente da linha marxista de pensamento; b) a segunda, remete àqueles que denunciam "a decomposição da ideologia burguesa" que veem a ideologia dominante no presente de Lefort, identificada com essa mesma ideologia burguesa,

\footnotetext{
${ }^{133}$ A degradação do conceito se faz tanto pelo uso que sociólogos e historiadores fazem, quanto por parte de militantes revolucionários. Temos, de um lado, uma crítica àqueles que se colocam sob a autoridade da Ciência e, por outro, daqueles cujo saber está atrelado ao Partido, à lógica revolucionária. Lefort preocupa-se também com a retomada de um debate sobre o fim das ideologias, realizado nos anos 1960, que parece haver adquirido força novamente no início dos anos 1970.
} 
definida pelos traços outrora constituídos pelo movimento marxista. Nessa última perspectiva, é salutar para Lefort que, ao ver sua decomposição, cede-se "ora à ficção de uma revolução em curso e prestes a desaguar, ora a uma dominação e exploração 'selvagens', incapazes doravante de reconhecer e fazer reconhecer sua legitimidade."(FH, [1974] 1979b, p. 297); e c) a terceira, considera que todo pensamento é inscrito no reino da ideologia, em que alguns até exigem uma ideologia do proletariado. Neste caso, Lefort afirma que o conceito não conserva qualquer traço da acepção primeira e da qual recebia força: "a ideologia é reduzida às idéias que se defende para assegurar o triunfo de uma classe [...]" (ibid., p. 297).

Lefort considera, então, que este debate não nos coloca na condição de interrogar a ideologia. A clivagem entre a ordem da prática e a da representação mostra-se ignorada, chegando a ser até mesmo dissimulada, constituindo, no que tange ao próprio entendimento da ideologia, uma cegueira ideológica, calcada no desconhecimento do problema da ideologia. Esta "aparente" crítica, então, não reenvia a discussão ao seu núcleo: a divisão, conforme vimos no segundo capítulo.

Assim, graças a uma astúcia notável, a ideologia passou a figurar quase o contrário daquilo que designava. Lógica das ideias dominantes, subtraída ao conhecimento dos atores sociais e revelando-se apenas pela interpretação, na crítica dos enunciados e de seus encadeamentos manifestos, vê-se hoje reduzida ao "corpus" de teses, ao aparelho de crenças que fornece a armação visível de uma prática coletiva identificada com o discurso democrático-liberal, para uns, com o leninista ou stalinista (até mesmo o maoista ou trotskista), para outros, ou ainda com o discurso fascista, tais como se apresentam. (FH, [1974] 1979b, p. 297, grifos do autor)

Neste trecho, verificamos que Lefort retoma a ideia de que a ideologia é "lógica das ideias dominantes", "subtraída ao conhecimento dos atores sociais", requerendo a interpretação (l'interprétation). Somente dessa forma a ideologia pode ser revelada como sendo ideologia, um trabalho que requer a crítica de seus enunciados, de seus encadeamentos. Frente a esta perspectiva, no pensamento sobre a ideologia, esta última ter-se-ia se transformado em "teses", num aparelho de crenças, fornecendo uma armação para a prática coletiva. Assim, Lefort considera que há uma denegação no âmbito do próprio debate sobre a ideologia, que não a reabre como questão.

A segunda modalidade de discurso aparentemente crítico é aquele explicitado por Lefort com relação ao falso contradiscurso ideológico totalitário presente na França nos anos 1970. Neste discurso, que se pressupunha crítico, ele considera uma mudança 
notável em termos de linguagem, uma vez que, com a difusão de testemunhos e documentos, a multiplicação de análises e o livro de Soljenitsin O Arquipélago Gulag (1975), a esquerda manifestava uma nova sensibilidade ao fato burocrático e ao fato totalitário. Assim, ao invés de negar a existência do terror, a veracidade dos testemunhos e, enfim, que o regime soviético era totalitário, a esquerda passa a reconhecer este conjunto de fatos, admitindo os crimes de Stalin, as prisões e condenações impostas aos dissidentes do regime, mas não com o objetivo de arruinar a crença no empreendimento comunista da Europa Ocidental. Isto significa que a propagação de informações sobre o mundo totalitário teve um resultado ambíguo, pois, ao invés de alimentar uma crítica sobre a natureza do regime, ela é proferida (por exemplo, pelo partido comunista francês) com o intuito de fazer uma distinção entre o ideal que o anima e o projeto que foi estabelecido com problemas na URSS. Dessa forma, Lefort considera que os acontecimentos daqueles últimos anos, que contribuiriam para a crítica, acabaram resultando em um "ruído surdo", em um "tráfíco de linguagem", pois as palavras "totalitarismo", "totalitário", "burocracia" não continham toda a sua significação crítica, favorecendo, na verdade, "a arte da denegação" e, por fim, um recurso que se colocava à disposição da ideologia (EL, [1979f] 1979c, p. 16-17). Lefort questiona o significado de totalitário no vocabulário comunista, respondendo:

O epíteto se aplica a um poder autoritário, arbitrário, que transgride as fronteiras da responsabilidade pública para atender aos direitos dos indivíduos. Que significa: burocrático? A palavra designa métodos, mentalidades, comportamentos, uma disposição a seguir um modelo estabelecido, a obedecer às regras, a se remeter às ordens de cima, sem preocupar-se com casos concretos e inovações necessárias. Sem dúvida, podemos já atentar para uma crítica que se acompanha no partido francês de um modo de organização obstinadamente burocrático. Mas, mais importante é observar que esta linguagem impede de referenciar a natureza dos regimes, dizemos melhor, das formações sociais totalitárias, sobre as quais denunciamos parcimoniosamente as faltas. (EL, [1979f] 1979c, p. 17)

Nesse sentido, surge uma "falsa crítica ao totalitarismo" que é, na verdade, ideológica, pois procura abafar toda a significação do vocabulário crítico, uma vez que incorpora e reconcilia a própria contradição desvendada e presente em novos vocábulos.

Outro exemplo que gostaríamos de citar é a crítica surgida em Maio de 1968 e que foi reelaborada depois pela nova ideologia. Lefort a denominou como "a brecha", como "desordem nova" (cf. MORIN; LEFORT; CASTORIADIS, 2008) que sintetizava 
a reivindicação de uma desordem na sociedade, de uma contestação que colocava em causa todos os modelos de socialização moderna - a universidade, o hospital, a família, a igreja, as crenças, os costumes, a autoridade - que se afirmam como o ponto de vista da organização que procurava ordenar o mundo. Nessa perspectiva, o movimento de Maio de 68 abriu uma brecha na ordem burguesa-tecnocrática, criou uma janela para a circulação de ideias e a troca de pensamentos entre estranhos que consistiu em um mesmo trabalho, alargando o espaço público pela proliferação de panfletos, de discursos públicos, de slogans. Após esse acontecimento, no entanto, Lefort considera que se buscou "recompor a ordem nova" (LT, [1976a] 2007, p. 289), sendo a brecha colmatada pelo discurso da ideologia invisível que discutimos no terceiro capítulo. A crítica, como salienta Lefort, dirigia-se para a lógica de um conhecimento detido pela organização, o qual se mantinha relacionado à ciência, como sintetiza o autor:

A crítica coloca em causa o ponto de vista da organização, sob o qual tende a ordenar nosso mundo, a esquadrinhar cada setor do campo social, a etiquetagem dos indivíduos, todo um sistema de discriminação das disciplinas e das competências, da mensuração de atitudes, da exclusão dos desviantes da norma, da quantificação do trabalho, da programação dos conhecimentos. (LT, [1976a] 2007, p. 287)

Após Maio de 1968, no entanto, a nova ideologia "parece inverter a representação creditada à cientificidade, e [...] a transfere sob um novo registro ideológico" (ibid., p. 283), pois, agora, o discurso científico tornou-se discurso social e não mais discurso sobre o social. Ao mesmo tempo, tudo o que eclodiu com a contestação, toda a crítica à autoridade e à tradição foi lapidada para servir ao "culto do novo" (cf. LT, [1976a] 2007, p. 289 e FH, [1974] 1979b, p. 343) que nada mais é do que uma forma de se assegurar da morte do passado e da plenitude do presente. Assim, o discurso coletivo é nutrido sempre pelas novas descobertas científicas, responsáveis por reestruturar os comportamentos e anular toda a reflexão advinda até então, colocando em marcha o eterno recomeço e o descarte de saberes não cientificizados.

Neste sentido, verificamos que a ideologia e a crítica participam de um mesmo jogo de interpretação. A nova ideologia nasce com a crítica e pode se constituir como "falsa crítica", utilizando-se de elementos do discurso crítico - no caso do discurso crítico em relação ao totalitarismo e das contestações de Maio de 1968 -, não para colocar em relevo o que estava oculto, mas para reafirmar as teses ideológicas sobre o 
social, para manter o recobrimento, utilizando-se de nova linguagem ${ }^{134}$. Assim, a ideologia mostra-se como discurso "aparentemente subversivo" (cf. LT, [1982a] 2007, p. 467), contendo a aparência de uma crítica, mas que, na verdade, tem o efeito de anular todo o seu significado crítico.

Ainda que o discurso destes intérpretes venha replicar o discurso crítico e duplicar o discurso ideológico, isto não impede que a leitura crítica seja feita e refeita a análise do intérprete. Há sempre esta possibilidade, seja na democracia seja no totalitarismo, porque o sujeito está sempre num limiar estreito entre a crítica e a reprodução da ideologia e, é importante frisar, seu pensamento não pode nunca ser totalmente recoberto e anulado no regime totalitário, nem se apagar completamente em um regime de democracia de massas pela opinião formadora, produzida pela mídia, por exemplo.

Neste ponto, novamente, questionamos o que faz com que haja o discurso crítico, ou melhor, por que alguns intérpretes são intérpretes críticos e outros intérpretes ideólogos? O que favoreceria cada uma destas condições?

Em cada época, o desejo dos homens põe em marcha o estabelecido pelo discurso ideológico como sendo a condição e a posição de cada um. Dizemos que a decifração da ideologia encontra-se na dependência do desejo de seu leitor. Tal pressuposto nos leva a dois autores importantes para Lefort, a saber, La Boétie ${ }^{135}$ e Maquiavel, nos quais encontramos, respectivamente, um entendimento sobre o desejo de liberdade e o desejo de não opressão que, articulados pela linguagem, têm o efeito de impulsionar a interrogação. Devemos considerar que a nossa fala não se desprende do discurso ideológico e, por isso mesmo, ela faz tremer em cada um de nós o desejo que nos anima.

Em relação a La Boétie (1999), por meio do Discurso da servidão voluntária, podemos compreender o significado do desejo como fonte de interrogação política

\footnotetext{
${ }^{134}$ A ideologia, portanto, ao se estabelecer sobre o discurso crítico, acolhe e reconcilia toda a contradição apresentada pela crítica, constituindo uma espécie de "duplipensamento", como concebido por George Orwell, no livro 1984, o qual inverte os termos como na seguinte ideia "o Ministério da Paz cuida dos assuntos de guerra; o Ministério da Verdade trata das mentiras; o Ministério do Amor pratica a tortura; e o Ministério da Pujança lida com a escassez de alimentos." (ORWELL, 2009, p. 254). Dessa maneira, as contradições são rearticuladas em Novafala que é reconhecida por todos e anula todo o significado da contradição.

${ }^{135}$ La Boétie pode ser considerado outro autor no qual podemos compreender o significado do desejo como fonte de interrogação política contra-ideológica.
} 
contra-ideológica, porque ao refletir sobre o desejo de servidão, ele desenvolve uma compreensão sobre a liberdade que nos remete a ideia de que todos devem ser uns, o que significa, na perspectiva de Lefort, recusar o totalitarismo no qual o povo se quer nomeado pelo fantasma do UM, assim como recusar a farsa da união que é forjada pela ideologia na democracia. La Boétie também nos remete a uma linguagem em que impera uma fala viva, uma fala do sujeito contraposta àquela em que se opera a ficção de uma unidade e, portanto, de que ocorreria um ultrapassamento das relações entre dominantes e dominados. Tal é o caso, na democracia, da palavra "povo" que vem alimentar um desejo de servidão. É, neste caminho, pela linguagem que podemos também reconhecer os signos da liberdade, o que nos leva a afirmação de Lefort sobre a necessidade de um discurso novo que venha mostrar que não se pode nem negar a diferença, nem defini-la (cf. LT, [1979e] 2007, p. 398-399).

Seguindo Maquiavel, em uma sociedade política, as questões nascem porque há o embate entre dois desejos: o desejo de dominar e o de não ser dominado. O essencial nesta divisão está na negação da dominação, fundada no desejo do povo que é sem objeto e não visa, como é o caso do desejo dos grandes, à riqueza, à condição e ao prestígio. É claro que poderá cobiçá-los, mas isso implicaria em desertar de sua posição, enquanto povo. Assim, tendo em vista que a especificidade do desejo do povo é não ser dominado, não ser oprimido e que, justamente, a negatividade deste desejo concorda com a liberdade da cidade e com a Lei, consideramos que este desejo constitui o motor da interrogação política que poderá colocar a ideologia em questão, implicando todos os significantes que ela abarca sobre a lei, o saber e o poder na sociedade. Dessa forma, passamos a refletir sobre certas relações resignificadas pela ideologia: o saber, a autoridade, a lei, o próprio desejo (FH, [1970a] 1979b, p. 166) e colocamos em marcha a recusa do adquirido por meio da contestação. $O$ desejo de não ser oprimido tem o efeito de desfazer as imagens criadas para mascarar a opressão sofrida pelo povo por parte dos Grandes.

Este confronto possibilita a crítica à ideologia, mas não a garante totalmente, pois o desejo deve estar atrelado a uma condição interrogadora dos sujeitos, implicando que eles devem colocar-se como leitores do mundo, assim como leitores da obra de pensamento. A leitura, como considera Lefort, é o "momento privilegiado no advento do sujeito, de sua relação consigo e com os outros, na constituição de sua imagem e na apropriação de uma dimensão da Lei” (DEP, [1979d] 1999a, p. 221). Trata-se, então, de 
uma experiência simbólica, na qual o olhar, a voz e o pensar permutam-se e, no qual, dá-se a constituição do sujeito. Nesse sentido, o trabalho de leitura é considerado como aquele que prepara para o trabalho de interpretação da ideologia, ou seja, na frequentação das obras, na implicação de pensamentos que se dá no não distanciamento entre o leitor e o escritor, é possível não apenas ter acesso a uma linguagem interrogativa, mas também tomá-la como momento de uma experiência que, agora, podemos nomear como acontecimento.

$\mathrm{Na}$ experiência da leitura, em virtude da linguagem do escritor, das questões que evoca em seu leitor e da complicação de pensamentos que os subentendem, surge o momento de uma significação, de uma fonte de sentido que não se restringe ao leitor próximo - aquele que está localizado no presente do escritor - mas permanece como possibilidade infinita, abarcando leitores que ainda não nasceram. Dessa maneira, cada leitor, em cada época, nas condições em que ocorre sua experiência política e sua vivência dos acontecimentos de seu tempo, poderá interpretar a obra e, ao fazê-lo, ele não apenas trava contato com uma linguagem interrogativa como também tem acesso a discursos críticos de outros tempos, fazendo-os falar novamente e rearticulando-os com o seu tempo presente. Nesse momento, encontramos uma indicação importante que diz respeito a esta ausência de fronteiras temporais entre os discursos críticos e a ideologia, pois eles se comunicam toda vez que acontece a interpretação. Antes de nos determos em nossa discussão final sobre tais questões, exploraremos um pouco mais o discurso interrogativo.

\subsection{A interrogação da ideologia}

Por ser um discurso lacunar, o discurso ideológico contém brechas nas quais a interrogação pode inserir-se e provocar a contradição. Além disso, consideramos que, frente a todas as teses estabelecidas pela ideologia sobre o que é o social e a História, estas acabam por retornar como questões, ou seja, por mais que o discurso ideológico produza afirmações conclusivas sobre o social em toda a amplitude conferida por Lefort a este termo, elas voltam a ser questões. Afinal, o deciframento da ideologia está indissociavelmente ligado à interrogação que não tem fim. 
A interrogação está vinculada à compreensão de um caráter não determinado do pensamento, seja ele do leitor ou do autor, e que consiste, no ato da leitura, em abolir as supostas fronteiras que há entre eles e evitar buscar, na fala do escritor, um sentido inteiramente positivo prometido ao seu conhecimento, como se não houvesse na linguagem desmentidos, silêncios, latências, o não saber, as ambiguidades que perpassam o trabalho de pensamento.

Para Lefort, devemos buscar, nas obras e na ideologia, as discordâncias, as contradições, as fraturas que implicam assumir a indeterminação do sentido e, dessa forma, dar-se à complicação. Este termo exprime esta outra condição em que ocorre a leitura, ao abandonar-se o pensamento de sobrevoo que procura encontrar, no discurso do autor, apenas o que está de acordo com a tese de leitura definida de antemão pelo intérprete, em que impera a lei da coerência, a fragmentação do discurso, rejeitando-se na obra tudo o que não se acomoda ao seu argumento. Complicar a leitura, então, não significa abster-se de deixá-la mais simples, mas sim, consentir que as perdas, os deslocamentos de ideias, os desvios presentes, no discurso do escritor, não se separam daquilo que foi dito, daquilo que adveio para o pensamento, porque, justamente, estes elementos dos quais o pensamento se faz não podem ser expurgados da obra, pois estão implicados no pensamento do escritor.

Nesta perspectiva, o discurso da obra é feito de movimentos de pensamento em que há recuos, questões não formuladas que, peremptoriamente, são negligenciadas pela leitura determinista da obra. A dúvida, então, que perpassa o discurso da obra não é mais o signo de uma falta, mas de abertura, assim como a insegurança que se dá no ato da interpretação deixa de ser mascarada pelo domínio, dessa maneira ocorre a abertura da obra e do pensamento. Revelado desta forma, o discurso da obra é o lugar do mesmo, no qual os pensamentos daqueles que a interpretam se localizam e se misturam aos pensamentos do autor, fazem deles os seus, as questões formuladas tornam-se as suas, abre-se a possibilidade de uma leitura crítica ou, então, de uma leitura ideológica da obra, porque ela está aberta para isso, em virtude dos seus movimentos e da questãoorigem que lança e que tem o efeito de reenviar seus leitores à instituição do social, ou melhor, ao discurso instituinte.

O trabalho de interrogação da ideologia segue esta mesma lógica. Ele não se dá a sua distância, mas se processa pela complicação, pois se encontra implicado nela, nas 
suas lacunas, brechas e fraturas, questionando seus paradoxos, aquilo que ela denega. Assim, interrogar é abrir o discurso ideológico, é desselá-lo (desceller), desvelá-lo, é constituir uma maneira de afirmar que, para além do campo de significações comuns constituído pela ideologia, desvele um sentido que faça vacilar a noção do real, ou ainda, o suposto real concebido pela ideologia. Este trabalho, ao ser feito, tem a possibilidade de criar uma passagem para um novo discurso interrogativo que reenvie os sujeitos ao discurso instituinte e os leve a elaborar novas questões no seu rastro.

A palavra não economiza a pena de pensar. Tanto que nós entendemos por interrogação o enunciado interrogativo, ou mesmo, a manutenção do modo interrogativo ao longo do discurso, tanto que não percebemos nela senão a privação da afirmação, mais geralmente um retrato fora da esfera do julgamento, nós permanecemos estrangeiros da verdade deste movimento. Há, de resto, uma maneira de interrogar, de semear os pontos de interrogação sobre o trajeto da análise, que não coloca em causa o estatuto do objeto, como pode ter uma maneira de afirmar que desvele fora do campo de significações convenientes um sentido que faça vacilar a noção do real. Mas quando nós não dobramos mais a interrogação no plano de enunciados interrogativos, quando nos esforçamos por tomar toda a medida e que ela se revela, por sua vez, como interrogação do ser e do sentido, então se deixa reconhecer a experiência que se institui da relação com a obra. (LTO, 1986c, p. 55)

Nesse sentido, a interrogação não acontece somente pelas perguntas, pois constitui um modo de colocar em questão certos sentidos instituídos pela linguagem ideológica. A interrogação deve ser entendida também como "ausência provisória de um saber" (CA, [1961] 1978f, p. 22) que buscou tapar a lacuna, a brecha na sociedade. Para que as questões nasçam, então, é preciso que haja certezas ideológicas, pois, para Lefort, a dúvida e a certeza são parentes, não se dissociam e todo o movimento para chegar à crítica surge de um "já pensado" pela ideologia que se mantém em nossos pensamentos. Desvelá-la, então, não significa ir até ela como um objeto, mas compreender que ela está no fundo de nossos pensamentos.

Uma vez semeados os pontos de interrogação no trajeto da análise, qual é o efeito da palavra interrogativa no trabalho de crítica à ideologia? É o de desprender os sujeitos do mundo da representação em que estavam engolfados, mas não para lhes atirar novas verdades e certezas que novamente o fechariam e que se instalariam no 
lugar daquelas que foram desseladas e, sim, para criar uma abertura, uma "eclosão" da representação, para reengendrar o movimento da interrogação ${ }^{136}$.

Como já afirmamos anteriormente, a interrogação está relacionada ao conflito de vontades presente na obra de Maquiavel $(1999 ; 2008)$ e ao desejo de liberdade apresentado por La Boétie (1999), dessa forma, a interrogação que incide sobre a ideologia não pode ser taxada de metafísica, uma vez que está atrelada ao desejo e ao ponto de vista dos sujeitos sociais, em cada tempo histórico, estejam eles na democracia ou no totalitarismo. Eles se encontram sob uma certa configuração do poder e da ideologia, não se desprendem dela e, por se descobrirem investidos por ela, podem criar suas próprias questões. Entendemos, dessa forma, que a contraideologia sempre poderá existir, pois a interrogação está fundada na divisão do desejo que está ancorado na divisão social.

O discurso da obra, por consequência, pode ser tomado como este discurso exemplarmente contraideológico que se comunica com outros discursos críticos proferidos em outros tempos e lugares. Como vimos, o discurso crítico da ideologia é aquele que nasce na interpretação, ele tem esta natureza porque é discurso que decifra e desvela o que há de paradoxal no discurso ideológico, na impossibilidade em que se encontra de se fechar em sua paixão do real (LTO, 1986c, p. 715). Este deciframento está sempre na dependência do leitor-intérprete, pois cabe a ele reatar e ligar os nós que compõem o discurso coletivo como discurso instituinte. Para fazer isso, as questões veiculadas devem ter o efeito de evidenciar o desmentido da ideologia, aquilo que ela oculta, isto é, a divisão social e a divisão temporal, que consistem em uma questãoorigem. Assim, o que faz a especificidade do discurso crítico está no fato de que ele nos reenvia a esta questão, abrindo passagem para questões subsequentes. Este trabalho implica a frequentação de discursos-outros, daqueles de intérpretes de outras épocas que conservaram esta mesma identidade, decifrando os discursos de seu tempo presente.

Neste diálogo, o discurso que critica a ideologia, nos termos em que temos esboçado até aqui, não tem fronteiras de espaço-tempo definidas. No caso de Maquiavel, por exemplo, as questões formuladas continuam a ser passadas e repassadas por nós e por aqueles que virão, porque elas nos reenviam ao enigma do discurso

\footnotetext{
${ }^{136}$ Não nos esqueçamos que há maneiras de interrogar que não colocam nada em questão efetivamente e que, portanto, não contribuem para estabelecer uma crítica à ideologia.
} 
instituinte. Ao mesmo tempo, guardamos na memória o percurso que segue seu discurso crítico e aquilo que a sua questão fez surgir, para que esta mesma tarefa possa se dar em recomeço, mas articulada às questões de cada presente histórico.

Ilustrativa, então, é a imagem de Roma evidenciada por Lefort a partir de Maquiavel, a qual mantém no ombro para pensar o seu tempo presente. Ela permanece instrutiva porque faz surgir toda a significação de algo que sempre se repete na sociedade histórica: o retorno dos mitos do passado para recobrir o novo, os possíveis que emergem como momento de um acontecimento que abala e remete os homens ao enigma de sua origem. Este é o momento em que pode haver a entrada em cena de fantasmas, anunciando a conservação da ordem e a recusa do adquirido que ocorre por uma abertura para a História, para as aventuras da contestação que anunciam possíveis. A sociedade histórica vive desta implicação de discursos, pois não há como acabar com a ideologia, como pensou Marx.

A pergunta crucial que acompanha silenciosamente toda a construção deste capítulo não pode mais ser deixada em suspenso: como conviver com a ideologia, já que ela não está fadada a acabar? Acreditamos que uma possível resposta deixa-se esquadrinhar no que Lefort diz sobre o pensamento do político.

\subsection{O pensamento do político como pensamento crítico da ideologia}

Partimos do pressuposto, que alcançamos a partir das análises empreendidas até o momento em nossa tese, de que o pensamento do político de Lefort se constituiu como pensamento que busca desselar, decifrar e desvelar a ideologia. Ele mantém-se articulado à dobra, colocando-a à prova em todos os temas e interrogações lançadas em seus inúmeros artigos, de modo a criar, por meio deles, uma abertura para criticá-la. A crítica, por sua vez, trava uma interrogação que reenvia seus leitores a questões que os colocam perante o problema da liberdade, da igualdade, dos direitos do homem, das formas de sociedade monárquica, democrática e totalitária, a fim de colocar em relevo tudo o que é denegado pela ideologia e que se faz sinal do político. Nesse sentido, todas as questões abordadas em seus textos, compõem desvios que nos remetem ao tema da ideologia, pois o que está em questão, em todos eles, é um modo de apreensão da democracia e do totalitarismo, dos direitos dos homens, em que Lefort coloca à prova para "desmanchar as armadilhas da crença ou de se subtrair à captura da ideologia" 
(DEP, [1992e] 1999a, p. 11). Nesse sentido, o pensamento do político de Lefort é um pensamento da ideologia, justamente porque procura colocar em relevo tudo o que ela denega e que compõe o político - o simbólico, particularmente, em termos das significações que discutimos até agora.

O pensamento do político exige uma ruptura com o ponto de vista da ciência em geral e com o ponto de vista da ciência e sociologia políticas em particular (PP, [1983b] 1991, p. 25), o que significa romper com a ideia da política concebida como ciência regional (cf. PP, [1980c] 1991, p. 115) e, portanto, da lógica que visa apreendêla como objeto do conhecimento distante de um sujeito conhecedor.

O termo restaura laços com a inspiração mais antiga e mais constante da filosofia política que se debruçou sobre os princípios geradores da sociedade, pensando a diferença entre as diversas formas de sociedade, abarcando a diferenciação de essência entre democracia, tirania e despotismo. Algo impensado pela ciência política que já nasce suprimindo tais questões. Desse modo, a investigação sobre as formas de sociedade, tal como pressuposta pelo pensamento do político, impede que se designe a política como um setor particular da vida social, longe de outros setores como o econômico, o estético, o religioso, por exemplo. Nessa perspectiva, o pensamento que se faz do político guarda uma relação com estudos que nos deram a conhecer outras formas de sociedade e, em cujo modo de reflexão, não há uma divisão entre domínios econômico, estético, religioso, etc ${ }^{137}$.

A expressão Antigo Regime nos dá uma dimensão daquilo que designa o político para Lefort. A ideia de um tipo de constituição, enquanto forma de governo, e a ideia de um estilo de existência, ou de um modo de vida, estão combinadas nessa expressão, concebida em termos de costumes e crenças, atestando "um conjunto de normas implícitas a comandar as noções de justo, injusto, bem e mal, desejável e indesejável, nobre e vil" (PP, [1986d] 1991, p. 11). A República de Platão também é ilustrativa deste pensar o político, justamente porque, nesta obra, não há um domínio próprio à política, conforme explicita Lefort.

\footnotetext{
${ }^{137}$ Registramos que a obra de Lefort se faz também em torno das reflexões da historiografia da Revolução Francesa, destacando-se os estudos de Michelet, Quinet, François Furet. Além da historiografia, há também como vimos uma relação permanente com os trabalhos antropológicos de Marcel Mauss, Pierre Clastres, entre outros e, também, com a literatura.
} 
A República - da qual é preciso lembrar que era guiada pela busca do que seria, em teoria, o bom regime -, longe de fixar os limites da política, exigia uma interrogação que incidisse, a um só tempo, sobre a origem do poder e sobre as condições de sua legitimidade, sobre a relação mando-obediência em toda extensão da sociedade, sobre as relações entre Cidade e exterior, sobre as necessidades sociais e a repartição das atividades profissionais, sobre a religião, sobre os fins respectivos do indivíduo e do corpo social - até levar ao reconhecimento de uma analogia entre a constituição da psique e a constituição da polis, e finalmente, o que não é menos notável, até sugerir que o discurso sobre a politeia, mais geralmente o diálogo, punha em causa relações de caráter político. (PP, [1986d] 1991, p. 11)

O político, diferentemente da noção de política, não se circunscreve nas relações de poder ou no que se nomeia atividade política, nem mesmo nas fronteiras do social, não podendo ser localizado na sociedade. Para Lefort, a própria noção de sociedade já contém a referência a uma definição política (PP, [1981b] 1991, p. 254), ou seja, falar em sociedade já implica pensá-la como sociedade política. Isso significa que a coexistência humana, as relações sociais - entre classes, grupos e indivíduos - , assim como as práticas, crenças e representações encontram-se na dependência de certos referenciais que não se localizam nas relações de produção, como na teoria marxista que assume o primado da esfera econômica, mas naquilo que Lefort denomina como a "dimensionalidade originária do social", o "esquema diretor", o "modo de instituição do social", os "princípios geradores", o "modo singular de instituição". Todos estes termos sinônimos no seu pensamento comandam

[...] um modo singular de diferenciação e de relacionamento das classes, dos grupos, ou das condições, e, simultaneamente, de um modo singular de discriminação dos referenciais em função dos quais se ordena a experiência da coexistência - referenciais econômicos, jurídicos, estéticos, religiosos [...] (PP, [1981b] 1991, p. 255).

O político, portanto, constitui um tipo de análise metassociológica (cf. PP, [1980c] 1991, p. 118), metapolítica (cf. LTO, 1986c, p. 556), contendo uma interrogação sobre o ser do social, preocupando-se com o fenômeno de sua instituição. Este termo abarca o sentido mesmo do verbo instituir, compreendendo "a maneira segundo a qual uma humanidade se diferencia ou, mais fortemente, se divide para existir como tal, da maneira pela qual dispõe de referências simbólicas para figurar o que lhe escapa: sua origem, a natureza, o tempo, o ser mesmo." (FH, [1978c] 1979b, p. 15) 
O ponto de partida reside na compreensão de que toda sociedade é, em sua essência, uma sociedade política e que um tipo de sociedade se distingue de outro em razão de seu regime, ou, como considera Lefort, por uma certa forma (mise en forme), um certo sentido (mise en sens) e uma certa representação (mise en scène) que adquire a coexistência humana. Nessa perspectiva, é o político quem dá forma à sociedade.

Assim, o conhecimento do político

[...] é o dos princípios geradores das sociedades e que põe em jogo uma reflexão sobre o destino ou os destinos do homem; pensamos, mais precisamente, que se o poder constitui o objeto privilegiado do conhecimento do político, é no sentido de que a definição que adquire aqui e acolá condiciona a formação (mise en forme) e a encenação (mise en scène) de um conjunto social. (ID, [1980d] 1983a, p. 98, grifos do autor)

Assim, pensar o político significa considerar que todos os elementos que circunscrevemos no plano da política - entidades (classes ou segmentos de classe), relações sociais, determinações econômicas ou técnicas - não podem ser plenamente compreendidos se não partirmos daquilo que lhes preexiste: a mise en forme, a mise en sens e a mise en scène do espaço social (PP, [1983b] 1991, p. 26).

Os diferentes regimes ou formas de sociedade contêm em si um princípio de internalização que pode dar conta de um modo específico de diferenciação e articulação entre classes, grupos e categorias sociais. A forma (mise en forme) pela qual uma sociedade institui a si mesma é sinônimo de instituição política, na acepção do verbo instituir, que não pode ser limitada ao real, não podendo, portanto, ser reduzida aos limites do social. Por mise en forme, Lefort compreende a instituição política da sociedade, é por meio dela que são fixadas a natureza e a representação do poder, a natureza e a representação da divisão social (divisão entre classes e grupos) e, simultaneamente, são agenciadas as dimensões de uma experiência do mundo.

A mise en forme envolve o engendramento de um sentido (mise en sens expressão que o autor afirma tomar de empréstimo de Piera Aulagnier), de um significado atingido nas práticas sociais, contribuindo para que o espaço social emerja como espaço de inteligibilidade, cujo significado encontra-se na dependência das relações entre real e imaginário, falso e verdadeiro, justo e injusto, normal e patológico. Além disso, há uma encenação (mise en scène) das relações sociais, através da qual a 
sociedade dá a si uma "quase-representação" em sua constituição aristocrática, monárquica ou despótica, democrática ou totalitária ${ }^{138}$. Essas três noções explicitam a compreensão de Lefort de que toda sociedade é uma "elaboração" (PP, [1981b] 1991, p. 255), a qual é fruto de uma experiência que ocorre no mundo, estando implicada no deciframento do Ser do social por meio da interrogação.

Dessa forma, o Antigo Regime e a democracia, assim como o totalitarismo, seriam formas de sociedade, de acordo com Lefort, as quais se tornam compreensíveis não apenas por caracteres empíricos a informar como ocorrem as relações sociais, como se caracterizam as instituições políticas, a apontar quais são as causas determinantes da passagem de uma a outra, mas em virtude do "enigma da instituição". Por esta noção, Lefort dá a entender que há questões inerentes à nossa experiência social que não se deixam descobrir a não ser mediante um "deciframento" - modo de pensar o político indagando nestas formas de sociedade aquilo "que se deixa e não se deixa demarcar", ou seja, o que é denegado - a divisão social no totalitarismo, as pistas relativas a uma herança - as ideologias totalitária e "invisível", por exemplo -, "os sinais de um remanejamento das relações sociais anteriores" - o que permanece na passagem do Antigo Regime para a democracia e desta para o totalitarismo -, "de um reinvestimento" - no totalitarismo, de certos elementos presentes na democracia.

Em vez de detectar as causas da passagem de uma formação para outra, não deveríamos sustentar - sem jamais esquecer que nossa interpretação se dá nos horizontes de nossa própria cultura, que nossas questões são devedoras de nossa experiência social - a exigência de pensar a História levando em conta a experiência do que eu denominava o enigma da instituição? (...) Podemos, ao contrário, indagar, e com boas razões, se não se deixam demarcar, em cada tipo de sociedade, seja qual for o lugar no qual incide a investigação, as pistas relativas a uma herança, os sinais de um remanejamento das relações sociais culturais anteriores, de um reinvestimento, numa nova experiência do mundo, de práticas e de crenças antigas [...] (DEP, [1987] 1999a, p. 326)

Nesse sentido, a análise do político atesta um retorno às fontes do pensamento político clássico, a fim de pôr em evidência um esquema ou um conjunto de esquemas

\footnotetext{
${ }^{138}$ No caso da sociedade democrática, o conflito político projeta-se numa espécie de encenação. A representação política constituiria esta cena, onde se expressam os conflitos cujos interesses afetam a sociedade em seu conjunto. Trata-se da exibição de todos os conflitos diante de todos, permitindo que a sociedade adquira sentido de unidade e de diferença. A representação política inaugura uma verdadeira cena política. Ela tem o efeito de produzir a imagem da unidade e da pluralidade ao mesmo tempo. A mise en scène, portanto, torna visível todo o esquema diretor da sociedade, tornando inteligíveis todos os princípios que a regem, que regem a mise en forme do social.
} 
de ações e de representações que comandam, ao mesmo tempo, "a mise en forme e a mise en scène de uma sociedade e, simultaneamente, sua dinâmica." (PP, [1980c] 1991, p. 115). O político é interpretação, interrogação, deciframento e complicação.

Se procuramos conceber uma nova relação com o político devemos começar por reconhecer que ela se esboça sob nossos olhos. Por isso, a primeira tarefa não é inventar; é interpretar, elevar à reflexão uma prática que não é certamente muda, mas que, necessariamente difusa, ignora seu alcance na generalidade do social e cujas formações políticas não podem, por natureza, extrair a verdade, que elas se empenham somente em utilizar e, em parte, não sem sucesso, em desarmar. (ID, [1980b] 1983a, p. 59)

Dessa maneira, propomos que o pensamento do político de Lefort pode ser entendido como pensamento crítico da ideologia. Em nossa perspectiva, ele buscou criar um modo de reflexão dos fenômenos políticos que tem a ideologia no seu âmago, justamente porque procura decifrar, desselar o discurso moderno que cria quaserepresentações sobre a política, responsáveis por denegar o simbólico. Consideramos que a literatura não tem trabalhado com esta perspectiva, compreendendo a distinção proposta pelo autor em relação à ciência política como uma divisão entre domínios de conhecimento, dando ênfase aos efeitos da sua reflexão do político nas discussões sobre o significado da democracia e do totalitarismo, mas não refletindo sobre qual vem a ser a relação entre essa interrogação - na forma de deciframento, desvelamento - e a ideologia, conforme estamos propondo ${ }^{139}$.

No pensamento do político a ocultação é instrutiva, assim como a denegação, porque é justamente em virtude do apagamento dos referenciais do campo social, dos referenciais da História, na crença em uma visão artificialista ou, ainda, na aparente autonomia dos sujeitos que estamos em condições de reconhecer o político. De certa forma, Lefort chega a esta compreensão pelo estudo dos discursos dos intérpretes de Maquiavel, pois, ao retomar o que haviam dito seus intérpretes predecessores, ele

\footnotetext{
${ }^{139}$ Referimo-nos a alguns trabalhos que procuram explicar o que vem a ser pensamento do político de Lefort, apontando suas consequências para o entendimento das formas de sociedade democrática e totalitária, mas não evidenciando que este pensamento mantém-se vinculado a uma interrogação da ideologia. Entre eles estão os artigos de Steinmetz-Jenkins (2009), Vries (2009) que abordam o político como dimensão oculta na sociedade moderna, mantendo-se articulado à política; os artigos de Flynn (1987) e (2012) que expõem os pontos de partida de Lefort em Maquiavel e em Merleau-Ponty na constituição de seu pensamento do político; bem como os trabalhos de Jennings (1997) e Rosanvallon (2010) que inserem Lefort no debate francês, o qual passou do marxismo a uma retomada do político e, ainda, o trabalho de Marchart (2007) que apresenta o significado do político em uma sociedade pósfundacional como é o caso da sociedade moderna, enquanto dimensão instituinte que se mantém na indeterminação.
} 
conclui que eles haviam encerrado uma compreensão sobre a obra em que uma parte considerável das reflexões daquele autor não havia sido explorada.

A diferença que Lefort estabelece entre o pensamento do político e a ciência e sociologia políticas não é fortuita, ele não procura apenas estabelecer uma fronteira entre disciplinas, trata-se de uma distinção fundamental, porque está relacionada ao problema da ideologia. Na linha do pensamento de Merleau-Ponty, Lefort considera o discurso da ciência e, em especial, destas ciências, como pensamento de sobrevoo que procura determinações sobre o significado da política.

Nesta leitura, então, entendemos que interrogar a ideologia é, no mesmo compasso, interrogar a servidão voluntária, os direitos do homem, o humanismo, o conhecimento científico (conceitos, teorias), o poder, a linguagem, o simbólico, os acontecimentos, a democracia, o totalitarismo. É consentir que os desvios nos levam até ela e que dela não nos separemos e que não venhamos a fugir à exigência de colocá-la em questão, mesmo que isso implique deixá-la em suspenso pelo tempo necessário, até que advenha o momento da abertura em que o sentido se manifeste. Este "estar em suspensão" quer dizer que a crítica exige um trabalho que requer a leitura de um sujeito que está no mundo. Ela não se dá automaticamente, mas como movimento que avança aos poucos, de deciframento em deciframento, desselando as dobras de que é feito o discurso sobre o social. A espera ou isto que está em suspenso, aqui e agora, sustenta o que não é ainda, aqui e agora, e está indissociavelmente ligado à interrogação.

A obra de Lefort, em toda a sua extensão, constitui uma crítica à ideologia mesmo quando não se refere a ela diretamente, pois a tem consigo em todas as suas reflexões, ou seja, a ideologia não é apenas mais um objeto de reflexão em sua obra, mas perpassa toda a obra, todo o seu pensamento, nos diversos temas e questões que aborda. Pensar a ideologia não implica apenas tratá-la como objeto direto do pensamento, mas consentir em fazer desvios para abarcá-la.

Assim, a sua escrita e a sua obra "se empenha[m] em contornar os lugares em que cada um se fixou para abrigar certezas" (DEP, [1992e] 1999a, p. 12), se esforça em decifrar, em criar uma passagem no mundo agitado das paixões, "em desmanchar as armadilhas da crença” (ibid., p. 11), em "desfazer a trama dos discursos dominantes" (LT, [1978e] 2007, p. 342). É por isso que o intérprete de Lefort não pode buscar o que ele quis dizer, tentando determinar o sentido de suas palavras, mas sim "o que o leva a 
falar" (DEP, [1992e] 1999a, p. 13). Isto significa, portanto, considerar os acontecimentos que lhe suscitaram os possíveis e lhe abriram a interrogação, bem como a ideologia de sua época, em relação à qual procurou uma passagem - uma brecha para ensejar a crítica.

Gostaríamos de fazer um último comentário sobre a quem pode se dirigir este discurso do político como contraideologia. Para tanto, retomamos a interpretação da obra de Maquiavel desenvolvida por Lefort, no momento em que ele compreende a importância dos jovens a quem seu discurso fora remetido.

Maquiavel escreve aos jovens florentinos. Podemos pensar que não é por acaso que seu discurso que visa pôr em questão a representação de Roma é dirigido a eles, pois eram alvos da ideologia que os influenciava. Seu discurso assume seu sentido em virtude do desejo de mudança que, segundo Lefort, é o mesmo desejo que supõe em seu leitor (FH, [1971b] 1979b, p. 172). A obra de Maquiavel, como ele resume, vem a ser aquela do discurso de um autor

[...] liberado das ilusões que, por um momento, havia podido nutrir em relação a Julião e Lourenço, convencido da insuficiência do seu primeiro tratado e da necessidade de atacar na raiz a ideologia de seu tempo, cujo mito da 'romanidade' de Florença é uma peça essencial, Maquiavel se põe a frequientar assiduamente um círculo composto em grande parte de jovens, que são ávidos por pensamentos novos e têm vontade de agir. (FH, [1971b] 1979b, p. 170).

Nesse sentido, a juventude é justamente aquela que não está presa às crenças e às práticas de seus pais ou comprometidos apenas com a manutenção das posições conquistadas. Assim, em toda crítica à ideologia está pressuposto o desejo do leitor, o que se torna especial quando se trata de jovens desejos, desejos de liberdade, de não servidão e de não dominação, uma negatividade profícua que é capaz de impedir o trabalho da ideologia.

Se as proposições de Lefort sobre a crítica à ideologia nos remetem a uma espécie de Paideia, então faz sentido pensarmos que a interrogação e a interpretação devem ser práticas constituídas ainda na juventude. Ao mesmo tempo, trata-se de uma fase na vida humana cercada por dúvidas, pela incerteza e por constantes interrogações sobre a condição futura, sendo momento de contestação também em torno de hierarquias e afirmações constituídas, como o foi em Maio de 1968. 


\section{Conclusão}

Ler e interpretar a obra de Claude Lefort significa transitar pelos seus inúmeros artigos, implicando um movimento de leitura e releitura que incluem pausas, certa demora em alguns trechos e artigos que são, por vezes, irônicos, enigmáticos, responsáveis por nos manter em um estado de interrogação permanente, pois o autor não fornece todas as respostas e definições que gostaríamos de encontrar em seus escritos. Este desvio deliberado da definição, da determinação e da certeza não significa ausência de rigor teórico, mas uma decisão que está no coração de sua postura filosófica, pois é preciso manter o leitor em suspenso pelo tempo necessário para que ele passe e repasse pelas mesmas questões, deixando-se trabalhar intensamente por elas. Aquele que lê sua obra, então, é levado a realizar uma incursão contínua, à frequentação ininterrupta de seus escritos, pois a todo instante Lefort reintroduz suas questões e as rearticula aos debates e ao cenário político de sua época.

A opção por esta escrita, que coloca o leitor em movimento pela reinstituição de sua fala através de seus artigos, não se dissocia de seu modo de pensar e filosofar que, em nossa perspectiva, manteve-se atrelado à ideologia. Esta foi a interpretação assumida neste trabalho, tendo sido discutida ao longo dos cinco capítulos, a qual foi movida pela percepção de que os intérpretes de Lefort, de um modo geral, veem a ideologia apenas como mais um dos temas discutidos pelo autor, enquanto, em nossa perspectiva, ela nos permite atingir também uma compreensão sobre o estatuto de seu discurso. De certa forma, os intérpretes incorrem em alguma "ilusão de ótica", pois, como já dissemos, no segundo capítulo, Lefort apresenta uma fala curta quando reflete diretamente sobre a ideologia, o que pode dar a falsa compreensão de que o autor a discutiu em apenas três de seus inúmeros escritos, além do capítulo presente em Le Travail de l'oeuvre Machiavel (1986c), em que a ideologia é pensada como um tipo de interpretação que se dá sobre a obra de pensamento. Nesse sentido, deixou-se de interrogar: a) por que a ideologia se mostra latente na maior parte de seus estudos, para aparecer explicitamente apenas por um curto período, no âmbito de sua vasta produção; b) as razões e implicações teóricas de sua escolha pelo desvio em relação a uma discussão conceitual; e, ainda, c) que suas reflexões relativas à "invenção democrática" não enfatizam apenas o seu caráter indeterminado, mas também as determinações, e o jogo mantido entre a determinação ideológica e a indeterminação, os quais lhe são 
inerentes e de fundamental importância para sua sorte, tanto no que se refere à uma potencial passagem ao totalitarismo como ao seu processo de reinvenção contínua.

Quando a ideologia é vista como apenas mais um tema, deixa-se de compreender a "obra" da ideologia no pensamento de Lefort, pois os seus movimentos de pensamento não se destacam da "dobra" do discurso instituinte, isto é, da ideologia com o objetivo de atingir a "brecha", ou seja, ele procura reenviar a todo instante o seu leitor à questão-origem da divisão social e temporal. Este reenvio é ininterrupto e pode ser compreendido como um processo instituinte, tanto de seu próprio pensamento, como no que diz respeito ao leitor que permanece em estado de questionamento. Esse traço torna-se visível quando encontramos o autor em debates e querelas intelectuais, nos quais sua fala mostra-se tenaz, sinuosa, "complicada", pois se dá como cruzamento de linguagens que lhe exigem deciframento, desvelamento. Nesse sentido, instalado no coração do pensamento político de sua época e aberto aos acontecimentos - Maio de 68, Hungria, Polônia, a queda do Muro de Berlim, Gorbatchev -, ele procurou desfazer a imagem da democracia como "democracia burguesa", buscando os sinais de sua "invenção", ao mesmo tempo em que faz a crítica à "cegueira da esquerda" com relação ao totalitarismo.

A ideologia está no pensamento de Lefort, pois sua postura nunca foi a de negar as certezas comuns que partilhou quando foi militante trotskista, por exemplo, compreendendo-se como aquele que também compartilha das ideologias, procurando sempre delas se evadir, criando movimentos para abrir um caminho, uma fenda, uma "brecha", na qual fosse possível manter o pensamento em estado interrogativo, em condição de "reinstituição". Ao mesmo tempo, como intérprete, buscou a representação que outras interpretações construíram sobre a obra de pensadores como Marx e Maquiavel, a fim de encontrar o que foi denegado nestas leituras, permanecendo oculto.

Isso significa, em nossa perspectiva, que a ideologia esteve sempre nos horizontes reflexivos de Lefort, em alguns momentos em forma de latências, em outros, em uma fala explícita. Com relação a esta última, vimos que, ao deixar de fazer uma reflexão conceitual da ideologia, isto que foi denominado "desvio", Lefort já adotava uma postura crítica, com o intuito de não fechar a significação da ideologia em determinações conceituais. Quando nos remete à forma de sociedade, percebemos algumas implicações teóricas para o debate acerca do tema. Primeiramente, a ideia de que há "ideologias" no plural, mas não no sentido de que há uma ideologia do proletariado, uma ideologia burguesa, mas sim que as ideologias nascem e renascem na 
sociedade histórica, estando vinculadas a cada "forma de sociedade", pois ela é desdobramento do discurso instituinte, necessariamente interrogativo, com o intuito de oferecer respostas ao que vem a ser o Ser do social. Nesse sentido, toda vez que os sujeitos sociais abrem uma fenda na sociedade, reinterrogando o que é o "ser do social", então, é preciso estar atento, pois uma nova ideologia está a caminho e, por isso, é importante lembrar que os seus enunciados estão ancorados no novo discurso instituinte surgido por esse questionamento. Dessa maneira, os enunciados que compõem a ideologia enquanto resposta, afirmação, determinação do social, variam de acordo com o tipo de sociedade em questão, isto é, com a experiência que cada uma delas pôde estabelecer em seu processo de interrogação.

Em segundo lugar, não é possível apresentar a realidade como critério que se afirma como verdade frente à ideologia. O real para Lefort não está dado, pois é "trama", é algo que precisa ser alcançado pelo trabalho de desselamento que é estabelecido pela crítica. Isso significa que o real é algo que se conquista toda vez que os sujeitos sociais decifram a ideologia, pelo reenvio de seus pensamentos à questãoorigem. Nesse sentido, o ponto de partida não está do lado do real, mas sim da própria ideologia que está no fundo de nossos pensamentos, de modo que estamos implicados em um trabalho incessante de questionamento das representações criadas por ela e de reinvenção de nossa sociedade histórica, justamente por esta ser marcada pela perda dos fundamentos que determinam a ordem social e pelo debate ininterrupto e movediço das ideologias.

Em terceiro lugar, a crítica à ideologia não se constrói como contradiscurso, se este for compreendido como afirmação contrária à ideologia. O que se denomina contradiscurso pode ser chamado, na perspectiva de Lefort, de desvelamento, deciframento, pois, para que se possa colocar a ideologia em contradição, é preciso criar o "desvio", deixar por um momento de confrontá-la, para ir ao encontro da questãoorigem. Dessa maneira, a ideologia pode ser desvelada pela pergunta que a coloca em contradição, pois as afirmações que ela oferece mostram-se como mentira generalizada. Enquanto não houver a interrogação, os indivíduos vivem no modo afirmativo, reproduzindo uma fala ideológica. É por isso também que Lefort não fala o tempo todo da ideologia, mas está sempre refletindo sobre as questões que lhe remetem à questãoorigem, ou seja, ele não procura afirmar um saber contrário ao que é afirmado pela ideologia, mas remete-se ao significado das práticas e pensamentos que são capazes de abrir "brechas" na racionalidade prevista pelo discurso ideológico. 
De certa forma, Lefort age como o arqueiro, pois impõe à sua flecha um desvio para atingir perfeitamente o seu alvo que é a ideologia. Em outras palavras, embora Lefort não fale diretamente da ideologia, em todos os seus estudos, todas as suas reflexões nos remetem a ela, uma vez que o desvio fundamenta-se na recusa em produzir um saber sobre ela, a fim de criar as condições para que o trabalho da crítica se exerça através do seu pensamento do político.

Finalizaremos com alguns apontamentos em relação à democracia, à qual demos atenção especial neste trabalho. Vimos a importância que adquire $o$ entendimento da "obra" da ideologia, no sentido de produzir determinadas representações sobre o significado das práticas democráticas, toda vez que uma nova questão abre uma fenda na sociedade. Nesse sentido, há sempre o surgimento de uma comunidade imaginária na democracia, a qual tem o efeito de petrificá-la em significações adquiridas, de modo a impedir que os sujeitos percebam que a lei, o poder e o saber dependem de um trabalho de enunciação e interrogação contínuos. O que quer dizer que, em cada setor, a interrogação é sempre convidada a se reestabelecer, especialmente quando consideramos a relação com o saber que nos preocupa em particular, pois, enquanto houver a maquinária do texto, a reprodução e a determinação de conceitos em sala de aula, continuaremos afastando a possibilidade de que os sujeitos sociais atuem no trabalho permanente de contestação política, de enunciação de seus direitos e de entre-conhecimento, que apenas existe por uma fala habitada pela interrogação. É claro que pode haver a ilusão do tudo dizível, do relativismo em que toda e qualquer verdade é aceita, mas é importante considerar que, na democracia, a palavra pode se deixar trabalhar pela palavra do outro, como troca, sem que o objetivo final seja buscar uma comunicação racional, ideal (cf. LT, [1989] 2007, p. 633-642). A legitimidade de um debate constante sobre os fundamentos da lei (a lei como enigma), do saber, do poder, das relações sociais, também está sujeita a cair no relativismo, no niilismo, mas a democracia continua sendo a mais exigente e a mais filosófica de todas as formas de sociedade. Importante é afirmar sempre um direito à palavra, da relação entre o enunciado e a enunciação, que a palavra se solte para que advenha o dizível, o pensável na democracia.

A perspectiva lefortiana mantém-nos em estado de alerta permanente, pois a democracia é algo que se conquista sem parar, já que seu espírito selvagem está sempre sujeito a se perder. Há o perigo da desvitalização democrática operada pela ideologia, e também a possibilidade contínua do seu deslizamento para o totalitarismo. 
Pensamos também nas revoluções democráticas deste início do século XXI, como a denominada "Primavera Árabe", em que uma nova via é aberta para a democracia, para a indeterminação. A reflexão em torno desta experiência, na linha lefortiana, também nos mantém alertas quanto ao jogo entre determinação e indeterminação que está em curso, em relação ao processo de "entulhamento" que pode ser produzido por uma nova ideologia a serviço da conservação e da busca por um fundamento para a ordem social. 


\section{BIBLIOGRAFIA}

ABENSOUR, M. (1993). Réflexions sur les deux interprétations du totalitarisme chez Claude Lefort. In: HABIB, C. ; MOUCHARD, C. La démocratie à l'oeuvre: autour de Claude Lefort. Turriers: Esprit.

(2002). 'Savage democracy' and 'principle of anarchy'. Philosophy \& Social Criticism. London, v. 28, n. 6, p. 703-726.

BARMINE. A. (1939) Vingt ans au service de l'U.R.S.S. Souvenirs d'un diplomate sovietique. Paris : Michel.

BOSI, A. (2010). Ideologia e contra-ideologia: temas e variações. São Paulo: Companhia das Letras.

BRECKMAN, W. (2012). Lefort and the symbolic dimension. Constellations, Oxford, v. 19, n. 1.

CHAUÍ, M. (1977). Crítica e ideologia. In: CHAUÍ, M. Cultura e democracia: o discurso competente e outras falas. 13 ed. São Paulo: Cortez, 2011.

. (1978). O discurso competente. In: CHAUÍ, M. Cultura e democracia: o discurso competente e outras falas. 13 ed. São Paulo: Cortez, 2011

(1984). Merleau-Ponty: vida e obra. In: MERLEAU-PONTY, M. Textos escolhidos. 2 ed. São Paulo: Abril Cultural. (Coleção Os Pensadores)

(1983). Apresentando o livro de Claude Lefort. In: LEFORT, Claude. A

Invenção democrática: os limites da dominação totalitária. São Paulo: Brasiliense, 1983.

. (2008). O que é ideologia. 2 ed. São Paulo: Brasiliense.

CHRISTOPHERSON, M. S. (2004). French intellectuals against the left: the antitotalitarian moment of the 1970s. Berghahn Books: New York, Oxford.

CILIGA, A. (1938). Au pays du grand mensonge. Paris. Plon.

EAGLETON, T. (1997). Ideologia. São Paulo: Editora da UNESP: Editora Boitempo.

EISENSTADT, S. N. (1998). The paradox of democratic regimes: fragility and transformability. Sociological Theory. Washington, v. 16, n. 3, p. 211-238.

FLYNN, B. (1984). The question of an ontology of the political: Arendt, MerleauPonty, Lefort. International Studies in Philosophy, v. XVI, n. 1, p. 01-24.

(1987). Claude Lefort: political forms of modern society. Philosophy and Social Criticism, v. 13, n. 1, p. 85-103.

. (2005). The philosophy of Claude Lefort: interpreting the political. Illinois: Northwestern University Press. 
(2012). Lefort as a phenomenologist of the political. Oxford, Constellations, v. 19 , n. 1, p. 16-22.

FRANÇA, F. C. T. (1998). Obra de pensamento e democracia: um diálogo com o pensamento de Claude Lefort. São Paulo. 212 f. Tese (Doutorado em Filosofia) FFLCH, Universidade de São Paulo, São Paulo.

GEENENS, R. (2008). Democracy, human rights and history: reading Lefort. European Journal of Political Theory. Brussels, v. 7, n. 3, p. 269-286.

HABIB, C.; MOUCHARD, C.; PACHET, P. (1993). Présentation. In: HABIB, C. ; MOUCHARD, C. La démocratie à l'oeuvre: autour de Claude Lefort. Turriers: Esprit.

JENNINGS, J. (1997). The return of the political? New french journals in the history of the political thought. History of Political Thought, v. XVIII, n. 1, p. 148-156.

KANTOROWICZ, E. H. (2007). The King's two bodies. A study in mediaeval political theology. Princeton: Princeton University Press.

KONDER, L. (2002). A questão da ideologia. São Paulo: Companhia das Letras.

KRAVCHENKO, V. A. (19--). Eu escolhi a liberdade: a vida privada e política de um funcionário soviético. 3 ed. Rio de Janeiro: A noite.

LA BOÉTIE, E. de. (1999). Discurso da servidão voluntária. São Paulo: Brasiliense. (Coleção Elogio da Filosofia)

LE ROBERT de poche. (2008). Langue Française. Paris: Le Robert-SEJER.

LEFORT, C. (1948). Kravchenko et le problème de L'URSS. In: LEFORT, C. Éléments d'une critique de la bureaucratie. 2ème ed. Paris: Gallimard, 1979c.

(1951). A troca e a luta dos homens. In: LEFORT, Claude. As formas da história: ensaios de antropologia política. São Paulo: Brasiliense, 1979 b.

. (1952a). L'expérience prolétarienne. In: LEFORT, C. Éléments d'une critique de la bureaucratie. 2ème ed. Paris: Gallimard, 1979c.

. (1952b). Sociedade "sem história" e historicidade. In: LEFORT, Claude. As formas da história: ensaios de antropologia política. São Paulo: Brasiliense, 1979b.

(1955). A alienação como conceito sociológico. In: LEFORT, Claude. As formas da história: ensaios de antropologia política. São Paulo: Brasiliense, 1979b.

(1956). Le totalitarisme sans Staline. L'URSS dans une nouvelle phase. In: LEFORT, C. Éléments d'une critique de la bureaucratie. 2ème ed. Paris: Gallimard, 1979c.

. (1958). Organisation et parti. Contribution à une discussion. In: LEFORT, C. Éléments d'une critique de la bureaucratie. 2ème ed. Paris: Gallimard, 1979c.

(1960a). Qu'est-ce que la bureaucratie? In: LEFORT, C. Éléments d'une critique de la bureaucratie. 2ème ed. Paris: Gallimard, 1979c. 
(1960b). Reflexões sociológicas sobre Maquiavel e Marx: a política e o real. In: LEFORT, Claude. As formas da história: ensaios de antropologia política. São Paulo: Brasiliense, 1979b.

(1961). L'idée d'être brut et d'esprit sauvage. In: LEFORT, C. Sur une colonne absente. Écrits autour de Merleau-Ponty. Paris: Gallimard, 1978f.

. (1963a). La dégradation idéologique du marxisme. In: LEFORT, C. Éléments d'une critique de la bureaucratie. 2ème ed. Paris: Gallimard, 1979c.

. (1963b). La politique et la pensée de la politique. In: LEFORT, Claude. Sur une colonne absente. Écrits autour de Merleau-Ponty. Paris: Gallimard, $1978 \mathrm{f}$.

(1965). Marx: de uma visão da história a outra. In: LEFORT, Claude. As formas da história: ensaios de antropologia política. São Paulo: Brasiliense, 1979b.

(1966a). Pour une sociologie de la démocratie. In: LEFORT, C. Éléments d'une critique de la bureaucratie. 2ème ed. Paris: Gallimard, 1979c.

(1966b). "...sur une colonne absente". Michaux. In: LEFORT, C. Sur une colonne absente. Écrits autour de Merleau-Ponty. Paris: Gallimard, $1978 \mathrm{f}$.

(1970a). A obra de pensamento e a história. In: LEFORT, Claude. As formas da história: ensaios de antropologia política. São Paulo: Brasiliense, $1979 \mathrm{~b}$.

(1970b). Le nouveau et l'attrait de la répétition. In: LEFORT, C. Éléments d'une critique de la bureaucratie. 2ème ed. Paris: Gallimard, 1979c.

. (1971a). Le corps, la chair. In: LEFORT, C. Sur une colonne absente. Écrits autour de Merleau-Ponty. Paris: Gallimard, 1978f.

(1971b). Maquiavel e os jovens. In: LEFORT, Claude. As formas da história: ensaios de antropologia política. São Paulo: Brasiliense, 1979b.

(1973). O nascimento da ideologia e do humanismo. In: LEFORT, Claude. As formas da história: ensaios de antropologia política. São Paulo: Brasiliense, 1979b.

(1974). Esboço de uma gênese da ideologia nas sociedades modernas. In: LEFORT, Claude. As formas da história: ensaios de antropologia política. São Paulo: Brasiliense, 1979b.

(1976a). Maintenant. In: LEFORT, C. Le temps présent. Écrits 1945-2005. Paris: Éditions Belin, 2007.

. (1976b). Un homme en trop. Réflexions sur 'L'Archipel du Goulag'. Paris: Seuil.

(1976c). Une idéologie de granit. In: LEFORT, C. Un homme en trop. Réflexions sur 'L'Archipel du Goulag'. Paris: Seuil.

(1977). Uma outra revolução. In: LEFORT, Claude. A invenção democrática: os limites da dominação totalitária. São Paulo: Brasiliense, 1983a.

(1978a). Les formes de l'histoire. Essais d'anthropologie politique. Paris: Galimmard. 
(1978b). Marx: de uma visão da história a outra. In: LEFORT, Claude. As formas da história: ensaios de antropologia política. São Paulo: Brasiliense, 1979b.

(1978c). Prefácio. In: LEFORT, Claude. As formas da história: ensaios de antropologia política. São Paulo: Brasiliense, 1979b.

(1978d). Repenser la démocratie. In: LEFORT, Claude. Le temps présent. Écrits 1945-2005. Paris: Belin, 2007.

(1978e). Repenser le politique: entretien avec E. A. El Maleh. In: LEFORT, Claude. Le temps présent. Écrits 1945-2005. Paris: Éditions Belin, 2007.

(1978f). Sur une colonne absente. Écrits autour de Merleau-Ponty. Paris: Gallimard.

(1979a). A imagem do corpo e o totalitarismo. In: LEFORT, Claude. A invenção democrática: os limites da dominação totalitária. São Paulo: Brasiliense, 1983a.

(1979b). As formas da história: ensaios de antropologia política. São Paulo: Brasiliense.

(1979c). Éléments d'une critique de la bureaucratie. 2ème ed. Paris: Gallimard.

(1979d). Formação e autoridade: a educação humanista. In: LEFORT, Claude. Desafios da escrita política. Tradução Eliana de Melo Souza. São Paulo: Discurso Editorial, 1999a.

(1979e) La communication démocratique. Entretien avec Paul Thibaud et Philippe Reynaud. In: LEFORT, Claude. Le temps présent. Écrits 1945-2005. Paris: Belin, 2007.

. (1979f). Prefácio. In: LEFORT, C. Éléments d'une critique de la bureaucratie. 2ème ed. Paris: Gallimard, 1979c.

. (1980a). A lógica totalitária. In: LEFORT, Claude. A invenção democrática: os limites da dominação totalitária. São Paulo: Brasiliense, $1983 a$.

(1980b). Direitos do homem e política. In: LEFORT, Claude. A invenção democrática: os limites da dominação totalitária. São Paulo: Brasiliense, 1983a.

. (1980c). Pensando a revolução na Revolução Francesa. In: LEFORT, Claude. Pensando o político: ensaios sobre democracia, revolução e liberdade. Tradução Eliana de Melo Souza. Rio de Janeiro: Paz e Terra, 1991.

. (1980d). Stalin e o stalinismo. In: LEFORT, Claude. A invenção democrática: os limites da dominação totalitária. São Paulo: Brasiliense, 1983a.

(1981a). L'invention démocratique. Les limites de la domination totalitaire. Paris: Fayard.

(1981b). Permanência do teológico-político? In: LEFORT, Claude. Pensando o político: ensaios sobre democracia, revolução e liberdade. Tradução Eliana de Melo Souza. Rio de Janeiro: Paz e Terra, 1991. 
(1981c). Reculer les frontières du possible. In: LEFORT, Claude. Le temps présent. Écrits 1945-2005. Paris: Belin, 2007.

(1981d). Stalin e o stalinismo. In: LEFORT, C. A invenção democrática: os limites da dominação totalitária. São Paulo: Brasiliense, 1983a.

. (1982a). Démocratie et avènement d'un 'lieu vide'. In: LEFORT, Claude. Le temps présent. Écrits 1945-2005. Paris: Belin, 2007.

(1982b). Le peuple et le pouvoir. In: LEFORT, Claude. Le temps présent. Écrits 1945-2005. Paris: Belin, 2007.

(1982c). Morte da imortalidade. In: LEFORT, Claude. Pensando o político: ensaios sobre democracia, revolução e liberdade. Tradução Eliana de Melo Souza. Rio de Janeiro: Paz e Terra, 1991.

(1982d). Reversibilidade: liberdade política e liberdade do indivíduo. In: LEFORT, Claude. Pensando o político: ensaios sobre democracia, revolução e liberdade. Tradução Eliana de Melo Souza. Rio de Janeiro: Paz e Terra, 1991.

. (1982e). Sur la nature des régimes de l'Est. In: LEFORT, C. Le temps présent. Écrits 1945-2005. Paris: Belin, 2007.

. (1983a). A invenção democrática: os limites da dominação totalitária. Tradução Isabel Marva Loureiro. São Paulo: Brasiliense.

(1983b). A questão da democracia. In: LEFORT, Claude. Pensando o político: ensaios sobre democracia, revolução e liberdade. Tradução Eliana de Melo Souza. Rio de Janeiro: Paz e Terra, 1991.

. (1984a). O corpo interposto: 1984 de George Orwell. In: LEFORT, Claude. Desafios da escrita política. Tradução Eliana de Melo Souza. São Paulo: Discurso Editorial, 1999a.

. (1984b). Os direitos do homem e o Estado-providência. In: LEFORT, Claude. Pensando o político: ensaios sobre democracia, revolução e liberdade. Tradução Eliana de Melo Souza. Rio de Janeiro: Paz e Terra, 1991.

. (1985). Filósofo? In: LEFORT, Claude. Desafios da escrita política. Tradução Eliana de Melo Souza. São Paulo: Discurso Editorial, 1999a.

. (1986a). Essais sur le politique. XIX $X^{e} X X^{e}$ siècles. Paris: Seuil.

(1986b). La dissolution des repères et l'enjeu démocratique. In: LEFORT, Claude. Le temps présent. Écrits 1945-2005. Paris: Belin, 2007.

. (1986c). Le travail de l'oeuvre Machiavel. 2ème ed. Paris: Gallimard.

(1986d). Prefácio. In: LEFORT, Claude. Pensando o político: ensaios sobre democracia, revolução e liberdade. Tradução Eliana de Melo Souza. Rio de Janeiro: Paz e Terra, 1991.

(1987). Dialogando com Pierre Clastres. In: LEFORT, Claude. Desafios da escrita política. Tradução Eliana de Melo Souza. São Paulo: Discurso Editorial, 1999a. 
. (1988). La pensée du politique. In: LEFORT, Claude. Le temps présent. Écrits 1945-2005. Paris: Belin, 2007.

(1989). La liberté à l'ère du relativisme. In: LEFORT, Claude. Le temps présent. Écrits 1945-2005. Paris: Belin, 2007.

. (1991). Pensando o político: ensaios sobre democracia, revolução e liberdade.

Tradução Eliana de Melo Souza. Rio de Janeiro: Paz e Terra.

. (1992a). Écrire. A l'épreuve du politique. Paris: Calmann-Lévi.

. (1992b). La representación no agota la democracia. In: SANTOS, M. R. dos. (coord.) ¿Qué queda de la representación política? Caracas: Editoral Nova Sociedad; Argentina: CLACSO.

. (1992c). Le sens historique. Stendhal et Nietzsche. In: LEFORT, Claude. Le temps présent. Écrits 1945-2005. Paris: Belin, 2007.

. (1992d). Maquiavel e a "veritá effetuale". In: LEFORT, Claude. Desafios da escrita política. Tradução Eliana de Melo Souza. São Paulo: Discurso Editorial, 1999a.

. (1992e). Prefácio. In: LEFORT, Claude. Desafios da escrita política. Tradução Eliana de Melo Souza. São Paulo: Discurso Editorial, 1999a.

. (1993). L’incertitude démocratique. In: LEFORT, Claude. Le temps présent. Écrits 1945-2005. Paris: Belin, 2007.

. (1996). Pensée politique et histoire. Entretien avec Pierre Pachet, Claude Mouchard, Claude Habib, Pierre Manent. In: LEFORT, Claude. Le temps présent. Écrits 1945-2005. Paris: Belin, 2007.

. (1999a). Desafios da escrita política. Tradução Eliana de Melo Souza. São Paulo: Discurso Editorial. (1999b). La complication. Retour sur le communisme. Paris: Fayard.

. (2000). Le pouvoir. In: LEFORT, Claude. Le temps présent. Écrits 1945-2005. Paris: Belin, 2007.

. (2007). Le temps présent. Écrits 1945-2005. Paris: Belin, 2007.

LEYDET, D. (1993). Phénoménologie du politique, normativité et droits de l'homme. Canadian Journal of Political Science. Quebec, v. 26, n. 2, p. 343-358.

LÖWY, M. (2009). As aventuras de Karl Marx contra o Barão de Münchhausen: marxismo e positivismo na sociologia do conhecimento. São Paulo: Cortez.

MAQUIAVEL, N. (1999). O Príncipe. Tradução Olívia Bauduh. São Paulo: Nova cultural. (Coleção Os Pensadores)

(2008). Comentários sobre a primeira década de Tito Lívio. $5^{\mathrm{a}}$ ed. Tradução Sérgio Bath. Brasília: Editora UnB.

MARCHART, O. (2007). Post-fundational political thought: political difference in Nancy, Lefort, Badiou and Laclau. Edinburgh: Edinburgh University Press. 
MARX, K. (1978). Manuscritos econômico-filosóficos e outros textos escolhidos. 2. ed. Traduções José Carlos Bruni (et. al.). São Paulo: Abril Cultural. (Coleção Os Pensadores)

, ENGELS, F. (2007). A ideologia alemã. Rio de Janeiro: Civilização brasileira. . (2008). O Capital: crítica da economia política. Rio de Janeiro: Civilização brasileira.

ENGELS, F. (2010). Manifesto Comunista. São Paulo: Boitempo editorial. 1. ed. revista.

(2011). Grundisse: manuscritos econômicos de 1857-1858: esboços da crítica da economia política. Tradução Mario Duayer. São Paulo: Boitempo; Rio de Janeiro: Ed. UFRJ.

MERLEAU-PONTY, M. (1952). A linguagem indireta e as vozes do silêncio. In: MERLEAU-PONTY, M. O olho e o espírito. São Paulo: Cosac \& Naif, 2004.

. (2006a). A estrutura do comportamento. São Paulo: Martins Fontes.

(2006b). Fenomenologia da percepção. São Paulo: Martins Fontes.

MICHELET, J. (1952). Histoire de la Révolution Française. Paris: Gallimard. 3 v.

MONNEROT, J. (1949). Sociologie du communisme. Paris : Gallimard.

MOLINA, E. (2005). Le défi du politique.Totalitarisme et démocratie chez Claude Lefort. Paris: L'Harmattan.

MONGIN, O. (1993). Un parcours politique. Du cercle des idéologies au cercle des croyances. In: HABIB, C. ; MOUCHARD, C. La démocratie à l'oeuvre: autour de Claude Lefort. Turriers: Esprit.

MORIN, E.; LEFORT, C.; CASTORIADIS, C. (2008). Mai 68 : la bréche suivi de vingt ans après. Paris: Fayard.

MOUCHARD, C. Lefort lecteur de Michaux. In: HABIB, C.; MOUCHARD, C.; PACHET, P. (1993). La démocratie à l'oeuvre: autour de Claude Lefort. Turriers: Esprit.

NÄSSTRÖM, S. (2006). Representative democracy as tautology. Ankersmit and Lefort on representation. European Journal of Political Theory. London, v. 5, n. 3, p. 321342.

NEWMAN, S. (2004). The place of power in political discourse. International political science review. London, v. 25, n. 2, p. 139-157.

OLIVEIRA, L. (2010). O enigma da Democracia: o pensamento de Claude Lefort. Piracicaba: Jacintha editores.

ORWELL, G. (2009). 1984. São Paulo: Companhia das Letras. 
PACHET, P. (1993). La reformulation dans l'oeuvre de Claude Lefort. In: HABIB, C. ; MOUCHARD, C. La démocratie à l'oeuvre: autour de Claude Lefort. Turriers: Esprit.

PLOT, M. (2012). Lefort and the question of democracy - in America. Constellations, Oxford, v. 19, n. 1, p. 51-62.

POLTIER, H. (1998) Passion du politique. La pensée de Claude Lefort. Genève: Labor et Fides.

ROSANVAllon, P. (2010). Por uma história do político. Tradução de Christian E. Cyril Lynch. São Paulo: Alameda.

RUMMERS, S. (2008). Deliberation interrupted. Confronting Jürgen Habermas with Claude Lefort. Philosophy and Social Criticism, London, v. 34, n. 4, p. 383-408.

SALINAS FORTES, L. R. (1979). Nota Introdutória. In: LEFORT, Claude. As formas da história: ensaios de antropologia política. São Paulo: Brasiliense, $1979 \mathrm{~b}$.

SOLJENITSIN, A. (1975). Arquipélago Gulag. São Paulo: Difel.

STEINMETZ-JENKINS, D. (2009). Claude Lefort and the illegitimacy of modernity. Journal for Cultural and Religious Theory, v.10, n. 1, p. 102-117.

THOMPSON, J.B. (1982). Ideology and the social imaginary. An appraisal of Castoriadis and Lefort. Theory and Society, v. 11, n. 5, p. 659-681.

. (1986). Editor's introduction. In: LEFORT, C. The political forms of modern society. Bureacracy, Democracy and Totalitarianism. Cambridge: Polity Press.

TOCQUEVILlE, A. (2005) A democracia na América. São Paulo: Martins Fontes.

VRIES, H. de. (2009). 'The miracle of love' and the turn to democracy. Michigan, The New Centennial Review, v. 8, n. 3, p. 237-290.

WARREN, M. E. (1996). What should expect from more democracy?: Radically democratic responses to politics. Political Theory, v. 24, n. 2, p. 241-270. 